\title{
After Slavery: The Rubin Hancock Farmstead, 1880-1916, Travis County, Texas
}

Marie E. Blake

Terri Myers

Follow this and additional works at: https://scholarworks.sfasu.edu/ita

Part of the American Material Culture Commons, Archaeological Anthropology Commons, Environmental Studies Commons, Other American Studies Commons, Other Arts and Humanities Commons, Other History of Art, Architecture, and Archaeology Commons, and the United States History Commons

Tell us how this article helped you.

This Article is brought to you for free and open access by the Center for Regional Heritage Research at SFA ScholarWorks. It has been accepted for inclusion in Index of Texas Archaeology: Open Access Gray Literature from the Lone Star State by an authorized editor of SFA ScholarWorks. For more information, please contact cdsscholarworks@sfasu.edu. 


\section{After Slavery: The Rubin Hancock Farmstead, 1880-1916, Travis County, Texas}

\section{Licensing Statement}

This is a work produced for the Texas Department of Transportation (TxDOT) by the report producer. TxDOT and the report producer jointly own all rights, title, and interest in and to all intellectual property developed under TXDOT's contract with the report producer. The report may be cited and brief passages from this publication may be reproduced without permission provided that credit is given to both TxDOT and the report producer. Permission to reprint an entire chapter, section, figures or tables must be obtained in advance from either the Supervisor of the Archeological Studies Branch, Environmental Affairs Division, Texas Department of Transportation, 125 East 11th Street, Austin, Texas, 78701 or from the report producer. 


\title{
AFTER SLAVERY: THE RUBIN HANCOCK FARMSTEAD, 1880-1916, TRAVIS COUNTY, TEXAS
}

\author{
by \\ Marie E. Blake \\ and \\ Terri Myers
}

Principal Investigator: Ross C. Fields

REPORTS OF INVESTIGATIONS, NUMBER 124

Prewitt and Associates, Inc.

Cultural Resources Services Austin, Texas

ARCHEOLOGY STUDIES PROGRAM, REPORT 19

Texas Department of Transportation

Environmental Affairs Division

December 1999

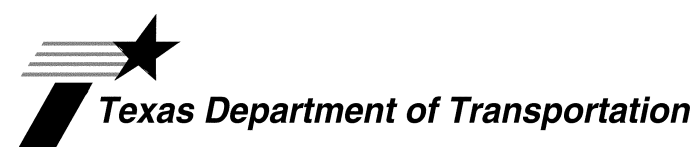

ISBN 0-9660796-8-x 


\section{CONTRACT DATA}

The preparation of this document was accomplished under Order No. 8-0331, Req. No. 60129-881270-B, with the Texas Department of Transportation, Environmental Affairs Division, 125 E. 11th Street, Austin, Texas, 78701-2483. 


\section{TABLE OF CONTENTS}

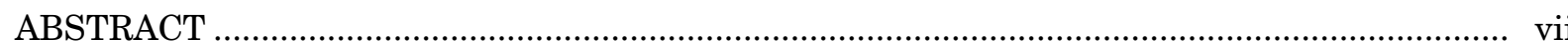

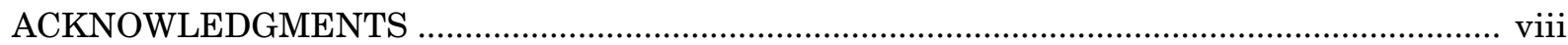

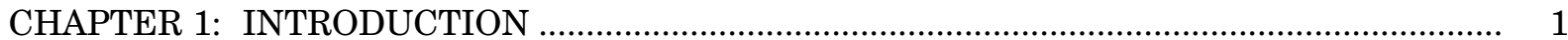

Project Objectives ...................................................................................................... 1

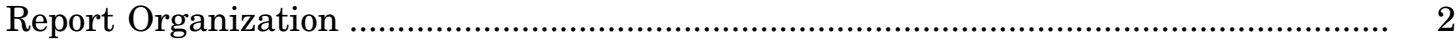

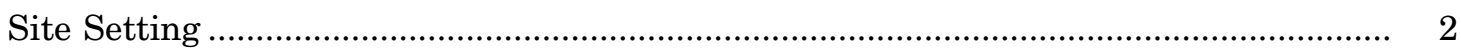

CHAPTER 2: PROJECT HISTORY …............................................................................... 5

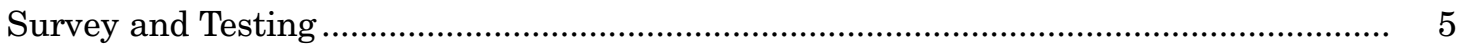

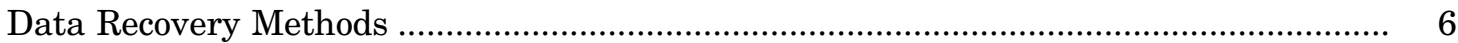

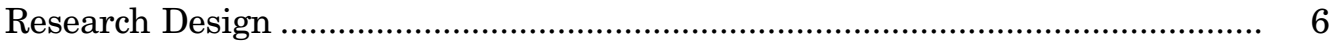

Preliminary Archival Research .............................................................. 6

Initial Oral History Interviews .................................................................... 6

Archeological Fieldwork ............................................................................... $\quad 7$

Summary of Fieldwork Accomplished …………............................................................ 8

Summary of Project History ........................................................................... 11

CHAPTER 3: HISTORICAL BACKGROUND ...................................................................... 15

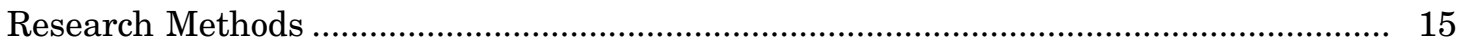

Chain of Title: Thomas M. Fowler Survey Land History ............................................ 17

The Rubin and Elizabeth Hancock Family .................................................................. 19

Origins of the Rubin Hancock Family in Travis County ................................................. 23

African American Settlement in North-Central Travis County After the Civil War ...... 26

Establishment of Duval and Waters Park ................................................................ 29

The African American Community in the Late Nineteenth Century .............................. 33

The African American Community in the Twentieth Century ........................................ 36

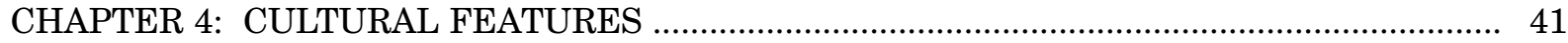

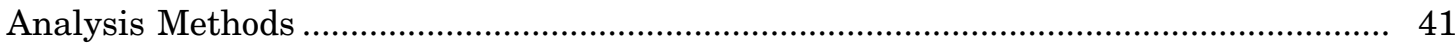

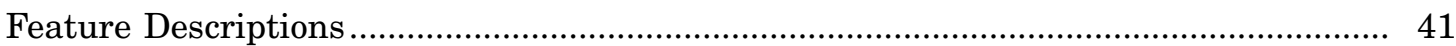

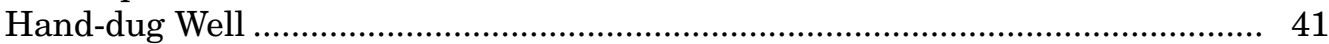

Drilled Well ............................................................................................ 43

Chimney Hearth and House Foundation .......................................................... 43

Fences and Fence Lines .................................................................................. 47

Yard and Garden Areas ............................................................................. 47

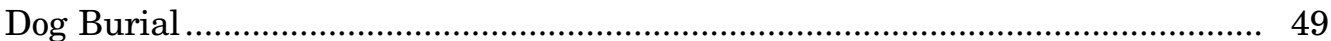

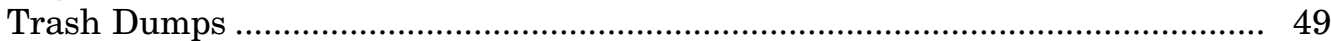

Possible Outbuilding Foundations ............................................................ 50

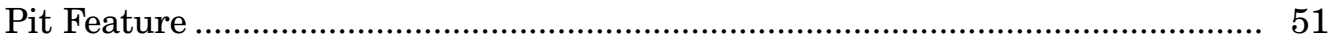

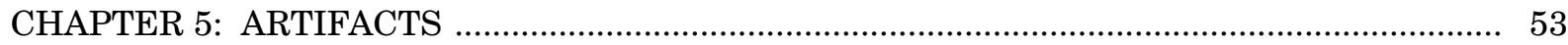

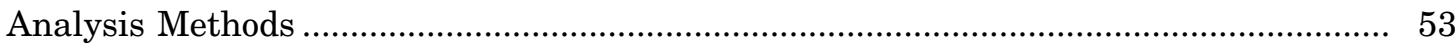




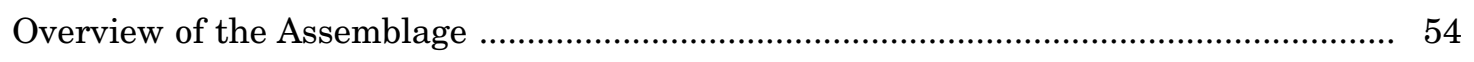

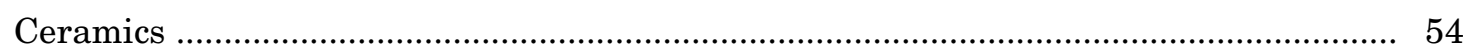

Makers' Marks ......................................................................................... 55

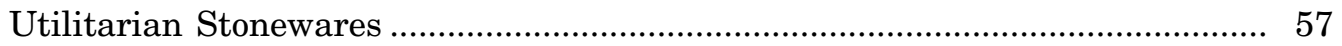

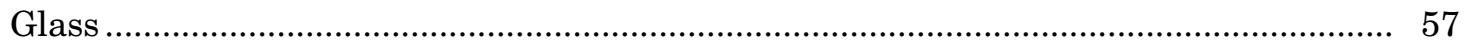

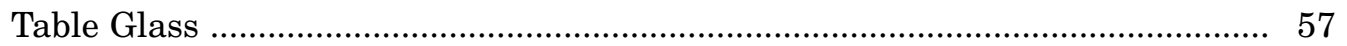

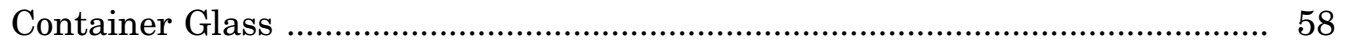

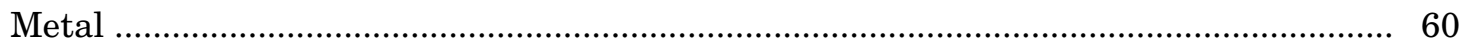

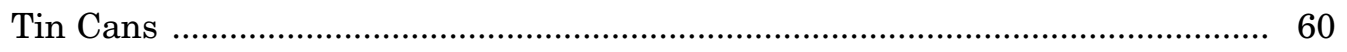

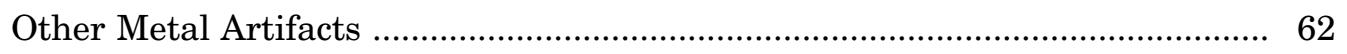

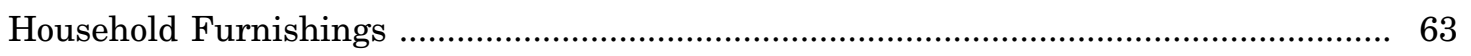

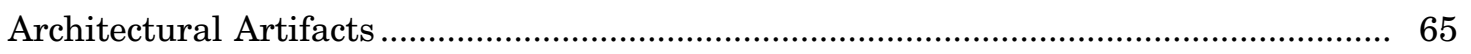

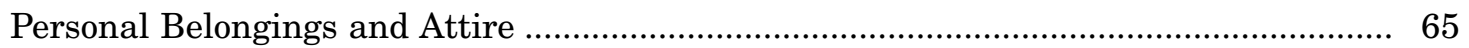

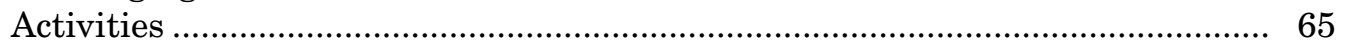

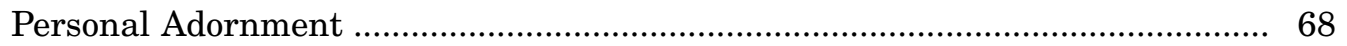

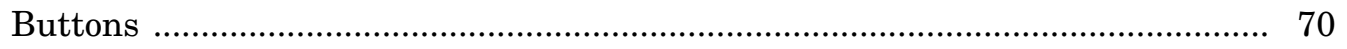

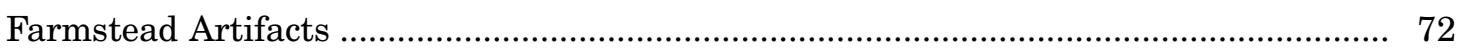

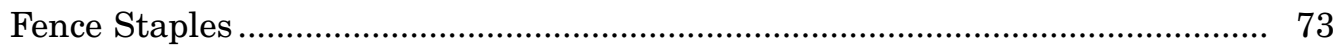

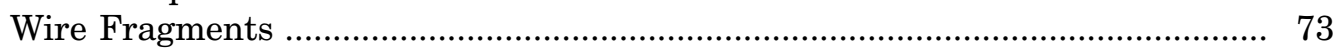

Miscellaneous Farmstead Artifacts ............................................................. 73

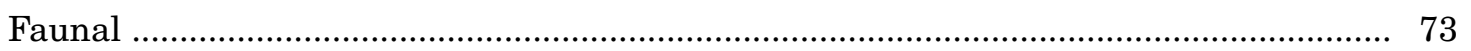

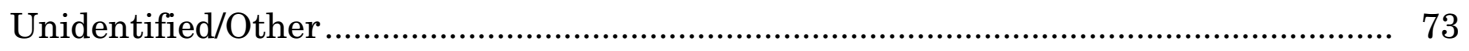

CHAPTER 6: THE RUBIN HANCOCK FARMSTEAD, CA. 1880-1916 …................................. 75

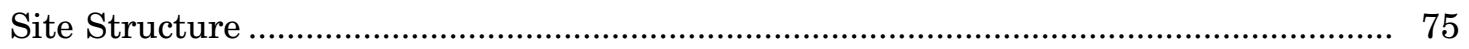

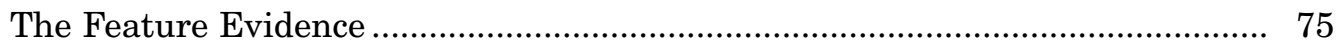

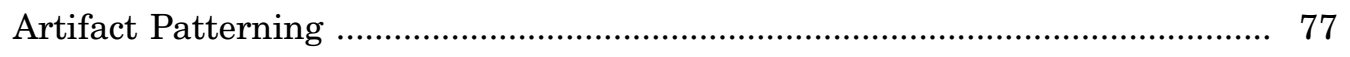

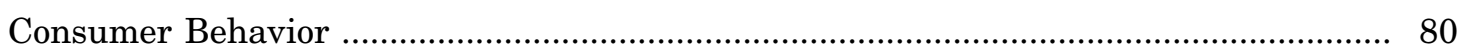

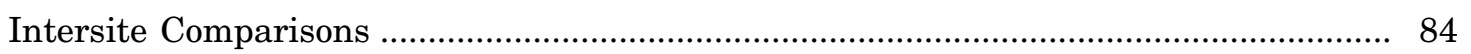

Waters Park, Travis County, Texas ........................................................... 85

The Town of Friendship, Delta County, Texas ................................................ 86

The Ned Peterson Farmstead, Brazos County, Texas ........................................ 88

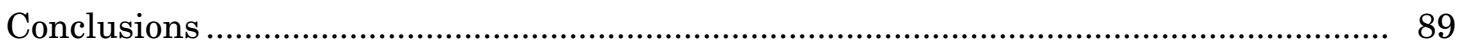

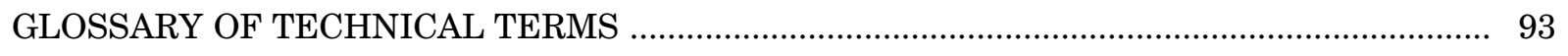

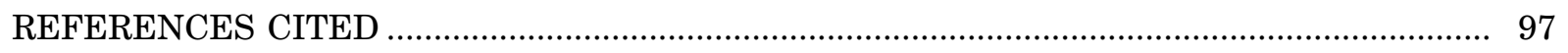

APPENDIX: Inventory of Historic Artifacts by Provenience

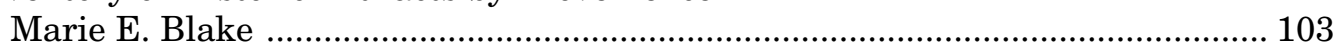




\section{LIST OF FIGURES}

1. Location map, 41TV875, the Rubin Hancock farmstead ................................................ 3

2. Site map showing topography, excavation units, and surface features ........................... 12

3. Excavations in the core historic area of 41TV875, facing grid west ................................. 13

4. Elizabeth and Rubin Hancock ...................................................................................... 16

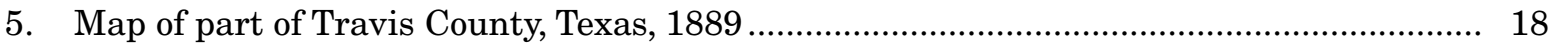

6. Genealogy of the Rubin Hancock family ........................................................................... 20

7. Mattie Hancock Hansborough …............................................................................... 21

8. Martha Ann Hancock Walker, ca. 1896 ........................................................................... 21

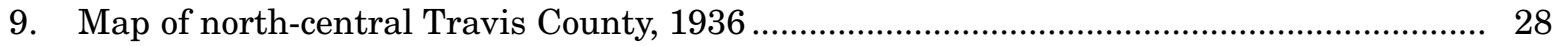

10. Advertisement for sale of lots at Duval ......................................................................... 30

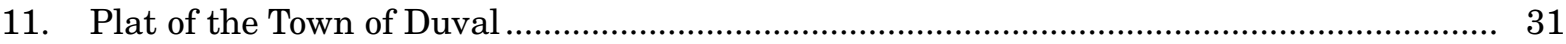

12. Section of 1910 USGS map of north-central Travis County showing the locations of Duval, Waters Park, and other communities ..................................................................... 32

13. Map of roads in north-central Travis County, 1898-1902, retraced in 1915, showing schools and land owners with the project area shaded .................................... 37

14. Cross section of hand-dug well and photograph of well opening ...................................... 42

15. Plan of the chimney hearth and house foundation as exposed in excavations in the core historic area

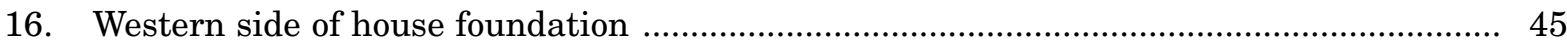

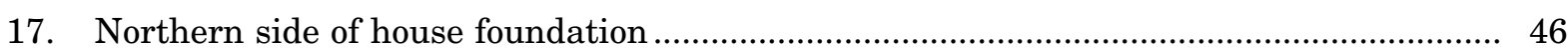

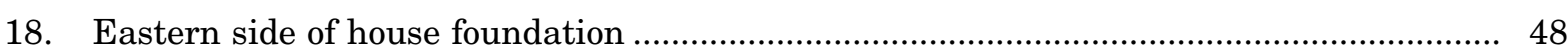

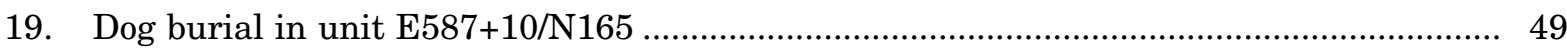

20. Possible outbuilding foundation in units E588+55/N50, E588+55/N55, and E588+60/N50

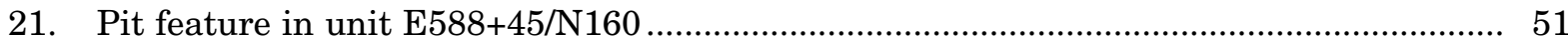

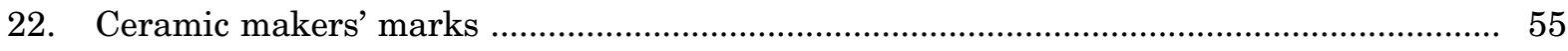

23. Hand-painted Japanese porcelain cup-plate ................................................................... 56

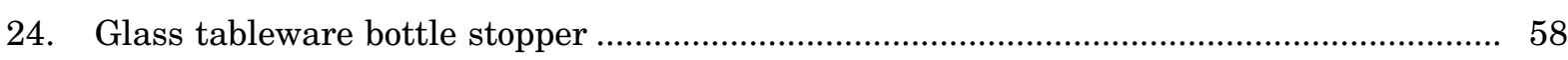

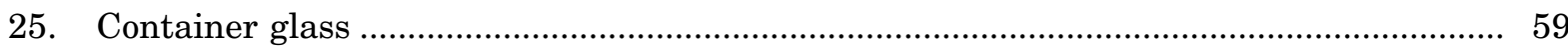

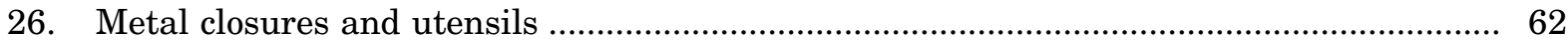

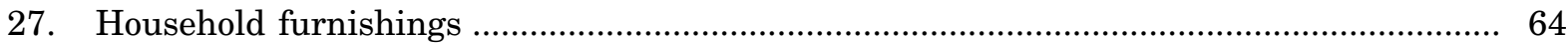

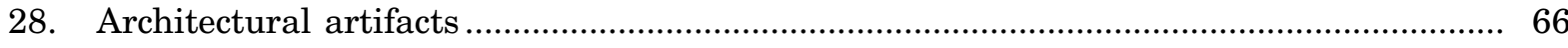

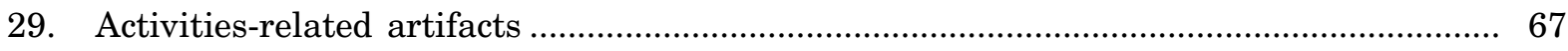

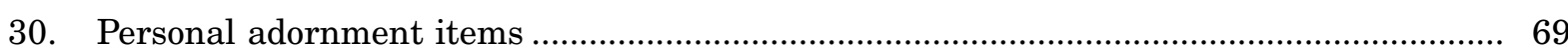

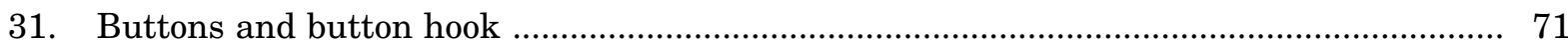

32. Layout of the Rubin Hancock farmstead based on cultural features .............................. 76 
33. 1937 aerial photograph showing the Rubin Hancock farmstead ................................... 78

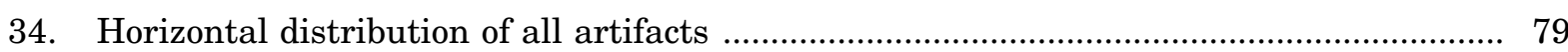

35. Horizontal distribution of cut nails ............................................................................ 81

36. Horizontal distribution of personal items ................................................................ 82

37. Horizontal distribution of refined earthenware ............................................................ 83

\section{LIST OF TABLES}

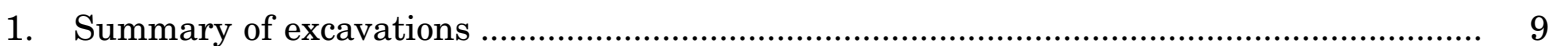

2. Summary of historic artifacts from 41TV875 ............................................................. 54

3. Inventory of ceramic and glass artifacts by provenience …........................................... 105

4. Inventory of metal artifacts, buttons, and personal attire/belongings artifacts by provenience

5. Inventory of architectural, farmstead, household/furnishings, and other artifacts by provenience 


\begin{abstract}
From 1984 to 1987, a series of survey, testing, and excavation projects was undertaken by the Texas State Department of Highways and Public Transportation (SDHPT, now the Texas Department of Transportation, TxDOT) at site 41TV875, the Rubin Hancock farmstead in Travis County. In 1998, TxDOT contracted with Prewitt and Associates, Inc., to complete the analysis, report production, and curation requirements for the mitigation work on both the prehistoric and historic components of the site.

The results of the prehistoric investigations are reported in a separate volume (Gadus et al. 2000). This volume details the history and archeology related to occupation of 41TV875 by the African American Hancock family from ca. 1880 to 1916. All previous investigations by SDHPT are discussed in detail. Using previous and current research, a thorough history of the Hancock family is presented. Rubin and his wife, Elizabeth, as well as many of their family members, had been slaves of the prominent Austin judge, John Hancock. Upon emancipation, Rubin and his three brothers along with their families became landowning farmers in the area north of Austin, which eventually developed into the small African American community of Duval. This historical research has been linked to the archeological features and material culture to develop an understanding of rural African American lifeways in central Texas at the turn of the century. This analysis has been compared and contrasted with research done at several other localities, including the adjacent Anglo American community of Waters Park, the African American community of Friendship in Delta County, and the farm owned by African American Ned Peterson in Brazos County.
\end{abstract}




\section{ACKNOWLEDGMENTS}

A variety of people worked in cooperation to bring this project to a successful completion. At the Texas Department of Transportation (TxDOT), Nancy Kenmotsu provided general oversight for completion of reports on both the historic and prehistoric components at 41TV875. Diane Dismukes at TxDOT managed the historic portion of the project and provided useful comments on the draft report. All original survey, testing, excavation, archival research and informant interviews done by TxDOT were undertaken or supervised by John W. Clark Jr. His tireless efforts on behalf of the Rubin Hancock site have preserved an important page in Texas history. The TxDOT excavation crew withstood a sweltering Texas summer and inundation by fire ants to work at 41TV875. During the two months of fieldwork, crew members included Gregory Hunter, Pat Garrett, Pat Corber, Tim Kibble, James Justice, Benji May, David Klipple, Wayne Young, Chuy Gonzalez, James Kaspar, and Randy Tesch. Informants Alma Shelby and Lillian Robinson provided Clark with a wealth of information available nowhere else.

Terri Myers of Hardy, Heck, Moore, and Myers, Inc., served as the Project Historian, expanding the archival and oral informant research begun by Clark. She authored Chapter 3 and worked closely with others on the project to share the results of her efforts. Mary S. Black of the Department of Curriculum and Instruction at The University of Texas at Austin developed a seventh-grade history unit plan for Texas public schools based on the actual history and archeology from the Rubin Hancock site.

The Project Historian is indebted to Eleanor Davis Thompson, Rubin Hancock's greatgranddaughter, for her ongoing assistance throughout the project and for use of her family photographs; to Mabel Walker Newton, Rubin Hancock's granddaughter, for her generous and open interview; and to Karen Collins for sharing her extensive research on John Hancock and his families. Others who contributed to the research include: Mrs. Andrew Coleman, whose father, Arch Adams, was one of the leaders of the St. Stephens Missionary Baptist Church in Waters Park; the Reverend Isaac Fontaine III, former pastor of St. Stephens Missionary Baptist Church in Waters Park; the current pastor, the Reverend Burnell J. E. McQueen; Eva Lindsey, who introduced the historian to the W. H. Passon Historical Society, an organization dedicated to the documentation of African American history in Austin and Travis County; Carolyn Jones, president of the society; the members of the W. H. Passon Historical Society; and the staff at the Austin History Center, State Library and Archives, Texas Historical Commission, and General Land Office.

Production of this report by Prewitt and Associates was a team effort. Ross C. Fields served as the Principal Investigator, patiently guiding the work in progress as well as reading and editing multiple drafts of the report. Marie E. Blake was the Project Historical Archeologist. Her primary tasks were to review all existing materials on 41TV875, analyze the artifacts and write all report chapters (except Chapter 3). Sandra L. Hannum prepared all of the figures in the report, in addition to generating the distribution maps from artifact data. Brian J. Wootan assisted Sandra with the graphics by scanning the artifact photos used as figures in Chapter 5. Karen M. Gardner managed all of the lab tasks, including preparing the collection for curation and assisting with the creation of the Appendix. Tracie L. Stone and Kyle Killian handled repackaging of the assemblage for curation. Audra L. Pineda was responsible for editing and report production.

Special thanks go to Teresita Majewski, who was kind enough to answer questions about porcelain for the artifact analysis and supply useful references. Marsha Prior of Geo-Marine, Inc., provided assistance to the Texas Historical Commission in reviewing the draft report and provided a number of helpful comments. Jack Rehm and Jim Cazares of Yellow Dog Photo took care of the project photographic needs, especially by making prints from original 1987 negatives and photographing the artifacts. 


\section{INTRODUCTION}

This report describes cultural resources investigations carried out at the historic component of 41TV875, the Rubin Hancock site, by the Texas State Department of Highways and Public Transportation (SDHPT, now the Texas Department of Transportation, TxDOT) in summer and fall 1987. This work was undertaken as part of the SDHPT's Parmer Lane project. The proposed project route extended FM 734 (Parmer Lane) from FM 1325 (Burnet Road) west to FM 620.

After survey and testing, SDHPT recommended the site as eligible for inclusion in the National Register of Historic Places under Criterion D. A nomination form was completed, and the site was determined eligible through consultation with the Advisory Council on Historic Preservation. Because it had been deemed eligible, a "No Adverse Effect Determination Report and Treatment Proposal" was developed for 41TV875. That plan included archival research and archeological excavation and was developed in consultation with SDHPT, the Advisory Council, and the State Historic Preservation Officer at the Texas Historical Commission. In 1987, Texas Antiquities Committee Archeology Permit No. 630 was issued for excavation of 41TV875. The fieldwork was supervised by John W. Clark Jr.- a member of the cultural resources staff at SDHPT, who also did the initial archival research and oral history work.

The mitigation plan was designed to address the historic archeological resources associated with the Rubin Hancock occupation. However, the excavations also revealed a prehistoric component consisting of three burned rock concentrations and abundant lithic artifacts for which additional effort was required. Other tasks specific to the prehistoric component included taking a soil profile column, collecting samples of burned rocks, and collecting samples of sediments associated with features.

Upon completion of the fieldwork, all artifacts, records, photographs, and other forms of documentation were returned to the SDHPT offices. Most of the artifacts were processed in the laboratory (i.e., they were washed, labeled, and inventoried) and some archival and oral history research was completed, however, final analysis and report production remained unfinished. In fall 1992, TxDOT contracted with the Texas Archeological Research Laboratory (TARL), The University of Texas at Austin, to conduct an evaluation of the records and materials from 41TV875. TARL made recommendations on research topics and a proposed budget appropriate for report production that would satisfy the requirements of the Antiquities Permit (Headrick 1993). In 1998, TxDOT contracted with Prewitt and Associates, Inc., to complete the analysis, report production, and curation requirements for the mitigation work on both components of $41 \mathrm{TV} 875$.

\section{PROJECT OBJECTIVES}

This project has four objectives, all of which revolve around describing the excavations and other research concerning 41TV875 begun in 1987. The primary objective is to produce a technical report (this volume) that describes and interprets the historic, African American occupation of 41TV875 by Rubin Hancock and his family. Artifact and feature analyses are utilized as the primary sources of archeological 
data. To place the Hancock occupation into a context of the experience of rural African Americans in central Texas in the late nineteenth and early twentieth centuries, additional archival and oral history research is included.

Next, as an outgrowth of the technical report, a curriculum unit plan for use at the seventh-grade level has been developed under state education standards. The unit plan focuses on the African American occupation of the site and how archeology provides insight into all aspects of history. The third objective is analysis of the prehistoric component at 41TV875; this is accomplished in a separate volume (Gadus et al. 2000). Finally, all materials, records, and artifacts related to this project have been prepared for curation at TARL.

\section{REPORT ORGANIZATION}

This report contains six chapters. Chapter 1 provides an introduction to the project, including a history of the consultation between agencies and a statement of the project objectives. It concludes with a description of the site setting. Chapter 2 details the history of the project. Specific attention is given to the survey and testing efforts at the site and the methods employed by SDHPT during the data recovery excavations, including the research design, preliminary archival research, initial oral history interviews, and archeological fieldwork. The amount and nature of the excavations are explained and presented in text, table, and map form. Chapter 3 includes the historical background of the Rubin Hancock occupation based on archival and oral informant research performed by John Clark Jr. and Terri Myers. Chapters 4, 5, and 6 directly address the archeological remains of the Rubin Hancock occupation at 41TV875. Chapter 4 describes the cultural features found in the excavations, Chapter 5 focuses on the artifacts, and Chapter 6 addresses site structure, intersite comparisons, and conclusions. References cited and a glossary of technical terms are offered after the final chapter, along with an inventory of the historic materials recovered by provenience.

\section{SITE SETTING}

When it was recorded, the Rubin Hancock site was located in north Austin, Travis County, Texas (Figure 1). It was situated on the east bank of Walnut Creek near its head, $600 \mathrm{ft}$ westnorthwest of the Southern Pacific railroad tracks and $100 \mathrm{ft}$ north of the Waters Park baseball park. The site sat at the foot of a low hill. The site was bounded on the north by an abandoned east-west road, on the east by a ditch for a buried sewer line, on the south by a barbed wire fence, and on the west by a stone yard fence and an abandoned fence line indicated by a linear growth of hackberry trees (Clark 1985a:2).

At the time it was excavated, the site was vegetated with large and small live oaks, junipers, and hackberries that tended to form alignments along former fence lines. Other vegetation included smaller shrubs and a variety of short and tall grasses and forbs, particularly east of the site in what was previously a plowed field. Areas adjacent to the site were wooded, with the exception of the Waters Park baseball complex to the southeast (Clark 1985a:2).

The sediments were a mixture of alluvial and colluvial deposits, and soil depth varied from east to west across the site. In the eastern portion, sediment was almost nonexistent with Cretaceous limestone bedrock exposed in some areas. Soil depth increased substantially toward Walnut Creek, with deposits up to $6 \mathrm{ft}$ thick or more in some areas. The sediments consisted of sandy loam and light clay originating from overbank deposition by Walnut Creek and slopewash from the hill on which 41TV875 sits. The deposits contained small limestone pebbles (2-3 $\mathrm{mm}$ in diameter) (Clark 1985a:2). 



\section{PROJECT HISTORY}

\section{SURVEY AND TESTING}

On August 9, 1984, personnel from SDHPT surveyed the proposed route for the Parmer Lane extension. Eight sites were recorded in or near the right of way. Seven had been recorded previously and included both prehistoric and historic components. Only one new site was recorded, 41TV875. It was described as a historic housesite that predated 1937. It was the only site out of the eight that was recommended for further work because of its undisturbed condition and the presence of metal and glass artifacts.

Initial testing was scheduled to start during the week beginning February 25, 1985. At that time, the land had not been acquired by the state and was still owned by the Burnet Road Land Joint Venture. A variety of surface cultural features were reported. A hand-dug, stone-lined well was present on the eastern side of the site. A galvanized metal pipe for a later drilled well was reported ca. $20 \mathrm{ft}$ to the west. Immediately east of the drilled well was an animal pen constructed of juniper posts and barbed wire. Many cut nails were reported in one of the posts. In the northwest area of the site, two segments of a low, dry-laid stone wall were observed. The north-south section was approximately $80 \mathrm{ft}$ long and turned east for approximately another $40 \mathrm{ft}$. It was hypothesized that this wall represented the lower portion of a post and barbed wire fence. An abandoned roadbed was noted north of the site (Clark 1985a:4), and an artifact scatter was observed across the site surface. Artifacts included numerous tin cans, sheet iron, barbed wire, barrel hoops, and wire, as well as single glass and ceramic sherds. Only the cut nails in the fence post were considered to be temporally diagnostic, suggestive of pre1890 construction (Clark 1985a:4).

The testing effort consisted of a metal detector survey designed to locate concentrations of buried artifacts/metal. A grid of $20-\mathrm{ft}$ squares was staked out and linked to the right of way center line. The grid was limited to the defined boundaries of the site. SDHPT staff performed the survey on February 27, 1985. Several areas of surface and subsurface metal were detected and plotted on a topographic map. Positive metal detector readings were fairly evenly distributed across the area. Based on the results of the metal detector survey, it was determined that the area of intensive occupation $(140 \times 100 \mathrm{ft})$ was smaller than the total grid area. It also was noted that no concentrations of metal were detected in the area believed to have contained the house, as indicated by the presence of alignments of stones on the surface (Clark 1985a:7).

In addition to the archeological fieldwork, archival research was conducted on the history of the site. A brief chain of title was presented, along with an indication of a cloud on the title. Research revealed that the site had been occupied by an African American family from ca. 1870 to 1920 , and that Rubin Hancock was in residence on the property in 1881 . The author suggested that research on such a site could fill an important data gap. Archeological work had been performed at antebellum slave and freeBlack sites, as well as postbellum Anglo American sites, but little work had been done to address postbellum African American occupations (Clark 1985a:6, 8).

At the end of the testing effort, it was concluded that 41 TV875 met the eligibility requirements for listing in the National Register 
of Historic Places under Criterion D. Clark (1985a:6, 9) argued that the date range of occupation had been established through archival sources, surface features were present, the site was seemingly undisturbed, and concentrations of artifacts/metal had been located with the metal detector survey. $\mathrm{He}$ concluded, therefore, that the site had the potential to address questions of a scientific nature. Based on the results of testing and the subsequent recommendations, a data recovery proposal was prepared for 41TV875.

\section{DATA RECOVERY METHODS}

This section presents the methods employed by SDHPT for data recovery at 41TV875. Specific discussions include the research design, preliminary archival research, initial oral history interviews, and methods used in the archeological fieldwork.

\section{Research Design}

The research design for data recovery at 41TV875 (Clark 1985b) outlined 12 objectives for the work and focused exclusively on the historic component. Those objectives encompassed data deemed recoverable from both archival and archeological sources. Five of the objectives were discussed in greater length, and specific methods were offered to recover the necessary data. All objectives were then distilled into three common goals for the research. Those goals were to "develop information on (1) the level of integration of the inhabitants of the area into national and local markets, (2) material manifestations of ethnicity and social status," and (3) artifact patterning as a manifestation of culture (Clark 1985b:7). Also included in the research design was a brief description of the personnel, duration, curation, and reporting plan for the excavation (Clark 1985b:8, 9).

\section{Preliminary Archival Research}

Subsequent to the discovery and eventual mitigation of 41TV875, preliminary archival research was conducted by SDHPT to identify the occupants of the site and to better understand the historical context of the archeological remains recovered. The chain of title was researched for the land on which 41TV875 is situated. Although there appeared to be a cloud on the title to the land, the initial efforts gave a good understanding of the development and settlement in the immediate vicinity. Other important documents located included Rubin Hancock's 1916 will, census material, latenineteenth- and early-twentieth-century maps of the surrounding communities, school census rolls, and marriage records. In researching the Rubin Hancock site and the nearby Waters Park community, which was investigated by SDHPT at about the same time in connection with the North MoPac project, over 2,100 pages of archival material were collected. A number of repositories were utilized in the archival research, including The Center for American History at The University of Texas at Austin, the Texas State Library and Archives, the Travis County Courthouse, and the Austin History Center.

\section{Initial Oral History Interviews}

Perhaps even more important than the archival research were the initial oral history interviews conducted by SDHPT. Unlike archival material that is available for an indefinite amount of time, valuable data from first-person recollections become scarcer as time passes. Older individuals who lived at the time and in the place being studied can forget details or even pass away, thus losing those insights forever. Clark conducted two extremely important interviews in October 1987. One was with 73-year old Lillian Robinson, great-niece of Rubin Hancock through her mother, Sophie. The second was with 78-year old Alma Shelby, a granddaughter of Rubin through her mother, Mattie. Both women were familiar with 41 TV875 when Rubin occupied it, and they supplied details that would not have been available otherwise. They were interviewed by phone and asked a set of questions covering their personal information; genealogies; and what they knew about site layout and available services, local economic pursuits, school, church, and named individuals from the community. They answered the questions with varying amounts of detail. Additional information was provided as the informants saw fit, and they also generously supplied historic photographs of Hancock family members. 


\section{Archeological Fieldwork}

Data recovery excavations at 41TV875 were initiated beginning the week of July 20, 1987, and they were completed during the week ending October 9, 1987. The investigations were performed under the direction of John W. Clark Jr., and under the general supervision of Dr. Frank A. Weir, Director of Archaeological Studies for SDHPT.

Al McGraw of SDHPT directed the first week of work at the site. During that time, the grid system for the excavation was established. All measurements and coordinates were made in the English/standard system. The center line stations for the Parmer Lane right of way were utilized as the baseline. Specifically, stations 586 through 589 were used to designate west-east measurements on the grid. Distances were designated in 5 -ft increments east of a given station, e.g., E587+20 would indicate a location $20 \mathrm{ft}$ east of center line station 587 . The northsouth axis was designated with a northing coordinate, with the N100 line along the right of way center line. Northing coordinates ranged from N0 at the southern end of the site to N200 at the north end, all falling within the Parmer Lane right of way corridor. Each excavation unit was assigned a coordinate designation with reference to its southeast corner.

Clark took over direction of the fieldwork on August 3, 1987. He maintained a log for each day of work at the site. All units were excavated by hand with a shovel or trowel when deemed necessary. All sediments were screened through $1 / 4$-inch-mesh hardware cloth. Due to the extreme thinness of the deposits in the eastern portion of the site where the historic component was primarily located, no vertical levels were used. Most of those units yielded only one level of deposits before limestone bedrock was encountered, usually at an average depth of 0.2 to $0.3 \mathrm{ft}$ and generally no more than $0.5 \mathrm{ft}$. In the western portion of the site where most of the prehistoric materials were encountered, the deposits were radically deeper, up to $6 \mathrm{ft}$ or more in some places. In that area, the units usually were excavated in 0.5 -ft increments.

As excavation progressed, each level of each unit was assigned a unique bag number. The bag numbers were assigned in numerical order on an as-needed basis and did not necessarily correspond with the sequence of levels within a unit. For example, Level 1 of unit E588+40/N100 was started on August 11 and assigned bag number 44 . Further work was not carried out in that unit until October 2, so Level 2 was assigned bag number 175. Assignments were recorded on a SDHPT bag log form which included information on bag number, unit coordinates, level, depth, description, and date.

Each excavation unit and its corresponding levels were documented on SDHPT record forms. Each form indicated the unit designation, the corresponding bag number(s), dimensions of the unit, the recorder's name, and the excavation date. In cases of shallow units with one level, a description of the matrix was given. In cases of deeper units with multiple levels, changes in soil color and inclusions were noted by level on one record form. Individual level forms were not utilized. The recovery of prehistoric tools (usually identified projectile points) also was often noted by level, and outlines sometimes were drawn on the record form. Presence or absence of artifact types such as historic materials or lithics was noted in deeper units. When encountered, the presence of gravels or bedrock at the base of a unit was indicated. Horizontal location relative to fence lines, the well, or other surface features was noted for units when appropriate. Units in the historic area of the site were identified relative to the site layout, such as "east of the house." The presence of historic features, such as the chimney hearth, within a unit was noted. Occasionally, historic features were sketched on the record forms. Separate feature forms or feature numbers were not utilized. Elevations were not taken on a regular basis, but some were indicated on the forms. Elevations were recorded more systematically during the first week of work and during work on the prehistoric component late in the project.

Besides sketches included on record forms, a variety of maps, plans, and profiles were drawn. A composite site map was drawn which included all subsurface excavations, historic surface features, modern surface features, some subsurface features, vegetation (identified to species), topography, site grid, and the interpreted location of the house. Fifteen plans and profiles were drawn of rock concentrations uncovered at the site. One specifically depicts the chimney hearth and a portion of the foundation. 
A plan view and cross section were drawn of the hand-dug well at 41TV875. Special efforts were made to explore the well and its contents. The well was open and had been used for refuse disposal during the twentieth century. This practice probably began with the advent of the drilled well as a primary source of water. No controlled excavation was undertaken, but an attempt was made to sample the deposits within the well. Fourteen boxes of modern debris were retrieved from the well and returned to the SDHPT lab. The intent was to dig beyond the modern debris and perhaps encounter historic deposits. However, at a depth of ca. $23 \mathrm{ft}$ below the surface, a void approximately $5 \mathrm{ft}$ deep was encountered. Eventually, the effort was abandoned due to the threat of structural collapse within the well. Historic deposits never were reached.

In addition to drawings, many photographs were taken. Some rolls have accompanying photo logs, whereas most do not. Four types of photography were used: $35-\mathrm{mm}$ color slides (122 frames); 35-mm black-and-white prints (80 frames); 1 1 $\frac{1}{2 \times} 2$-inch black-and-white prints (30 frames); and $2 \frac{1}{4} \times 2^{1 / 4}$-inch black-and-white prints (69 frames). Most aspects of the site were recorded photographically, including surface and subsurface features, profiles, and the general site area. Especially useful are the many "aerial" photographs of the site area taken from the bucket of a cherry picker.

The artifacts recovered were packaged and sent to the lab at SDHPT for washing and cataloging. In the lab, bag numbers were converted into lot numbers. For example, what was bag number 44 in the field became lot number 44 in the lab and in the specimen inventory. During lab processing, prehistoric and historic materials were separated, and each class of material was sorted into smaller analytical units and identified. For example, prehistoric materials were sorted into categories such as identified projectile points, bifaces, primary flakes, etc. Historic materials were sorted into categories such as ceramics by ware type, glass by color, different types of nails, and so on. In general, all materials were sorted into fairly specific categories. A specimen inventory was prepared which included lot number, number of specimens, description, location (horizontal and vertical), and associated references. Many finely rendered illustrations of both prehistoric and historic artifacts were included in the specimen inventory. A percentage of the artifacts were labeled with site and lot numbers. Artifacts were bagged according to lot number in the same categories listed in the specimen inventory. The bags were labeled on the exterior in indelible black ink with site number, lot number, artifact count, and description.

\section{SUMMARY OF FIELDWORK ACCOMPLISHED}

Excavation at $41 \mathrm{TV} 875$ was implemented in stages due to the additional effort required for the prehistoric component. When completed, 87 units were excavated, all of which measured $5 \times 5 \mathrm{ft}$ with the exception of one $2.5 \times 2.5-\mathrm{ft}$ excavation unit (Table 1, Figure 2). In addition, three trenches were excavated with a Gradall.

The initial effort focused on the historic component, although both historic and prehistoric artifacts were recovered. The first period of work consisted of 23 days between July 28 and August 28, 1987, with a crew of five or six. As previously mentioned, the deposits in the core historic area were shallow, and units located there were excavated no more than one level deep before bedrock was encountered (Figure 3). Not all units excavated during this period were shallow, however, and historic materials were recovered from the upper levels of all units regardless of their location across the site. Seventy-nine of the units (representing 144 levels), and three Gradall trenches were excavated during the first phase of work. Trench 1 was $70 \mathrm{ft}$ long, and Trenches 2 and 3 were $20 \mathrm{ft}$ long. Trench 1 was excavated to crosssection what appeared to be a filled stream channel, and the two shorter trenches were dug in an effort to locate a possible privy. No indication of a privy feature was found. Profiles were drawn of Trenches 1 and 3. Fill removed from the trenches was not screened.

The second phase of work focused on the prehistoric component and was conducted over 12 workdays between September 9 and October 7, 1987. Crew size varied but never was smaller than two individuals. Eight new units were excavated. Units E587+00/N160 and E587+00/ N170 were opened first, followed by units E587+00/N165 and E587+00/N155 in the area adjacent to Trench 3 . The final work took place in units E587+00/N175, E586+95/N170, 
Table 1. Summary of excavations

\begin{tabular}{|c|c|c|c|}
\hline Unit & $\begin{array}{l}\text { No. of } \\
\text { Levels }\end{array}$ & Depth (ft) & Comments \\
\hline E586+50/N160 & 3 & 1.5 & bedrock at base \\
\hline $\mathrm{E} 586+80 / \mathrm{N} 100$ & 2 & 1.0 & bedrock at base \\
\hline E586+80/N145 & 4 & 2.0 & bedrock at base \\
\hline $\mathrm{E} 586+80 / \mathrm{N} 165$ & 9 & 4.5 & \\
\hline $\mathrm{E} 586+80 / \mathrm{N} 195$ & 9 & 3.5 & ended in gravels \\
\hline $\mathrm{E} 586+85 / \mathrm{N} 75$ & 3 & 1.5 & \\
\hline E586+90/N175 & 3 & 1.5 & only southeastern quad excavated to retrieve lithic "cache" \\
\hline $\mathrm{E} 586+95 / \mathrm{N} 170$ & 5 & 2.5 & \\
\hline E586+95/N175 & 9 & 4.5 & \\
\hline $\mathrm{E} 587+00 / \mathrm{N} 155$ & 3 & 1.5 & large rocks at base \\
\hline $\mathrm{E} 587+00 / \mathrm{N} 160$ & 3 & 3.0 & only south half excavated to maximum depth \\
\hline $\mathrm{E} 587+00 / \mathrm{N} 165$ & 2 & 1.5 & \\
\hline $\mathrm{E} 587+00 / \mathrm{N} 170$ & 4 & 2.3 & \\
\hline $\mathrm{E} 587+00 / \mathrm{N} 175$ & 9 & 4.5 & uneven bedrock at base \\
\hline $\mathrm{E} 587+10 / \mathrm{N} 165$ & 1 & 0.5 & unit includes dog burial \\
\hline $\mathrm{E} 587+15 / \mathrm{N} 5$ & 3 & 1.5 & \\
\hline $\mathrm{E} 587+20 / \mathrm{N} 40$ & 1 & 0.5 & gravel at base \\
\hline $\mathrm{E} 587+25 / \mathrm{N} 120$ & 12 & 6.0 & gravel present \\
\hline $\mathrm{E} 587+25 / \mathrm{N} 130$ & 12 & 6.0 & gravel at base \\
\hline $\mathrm{E} 587+25 / \mathrm{N} 160$ & 6 & 3.0 & bedrock at base \\
\hline $\mathrm{E} 587+45 / \mathrm{N} 20$ & 3 & 1.5 & gravel at base \\
\hline $\mathrm{E} 587+45 / \mathrm{N} 100$ & 1 & 5.0 & entire unit dug in one level to $5 \mathrm{ft}$ \\
\hline $\mathrm{E} 587+50 / \mathrm{N} 55$ & 5 & 2.5 & gravel at base \\
\hline E587+55/N155 & 1 & $<0.5$ & \\
\hline $\mathrm{E} 587+55 / \mathrm{N} 160$ & 1 & $<0.5$ & \\
\hline E587+55/N165 & 1 & $<0.5$ & \\
\hline $\mathrm{E} 587+60 / \mathrm{N} 150$ & 1 & $<0.5$ & \\
\hline E587+60/N175 & 1 & 0.16 & \\
\hline E587+60/N180 & 1 & 0.13 & \\
\hline $\mathrm{E} 587+65 / \mathrm{N} 120$ & 1 & $<0.5$ & \\
\hline $\mathrm{E} 587+65 / \mathrm{N} 175$ & 1 & 0.77 & \\
\hline $\mathrm{E} 587+65 / \mathrm{N} 180$ & 1 & 0.36 & \\
\hline $\mathrm{E} 587+70 / \mathrm{N} 140$ & 1 & 0.2 & \\
\hline $\mathrm{E} 587+75 / \mathrm{N} 115$ & 1 & $<0.5$ & \\
\hline $\mathrm{E} 587+75 / \mathrm{N} 140$ & 1 & 0.2 & \\
\hline $\mathrm{E} 587+80 / \mathrm{N} 100$ & 1 & $<0.5$ & \\
\hline E587+80/N140 & 1 & 0.31 & \\
\hline $\mathrm{E} 587+80 / \mathrm{N} 160$ & 1 & $<0.5$ & \\
\hline $\mathrm{E} 587+85 / \mathrm{N} 20$ & 5 & 3.0 & \\
\hline
\end{tabular}


The Rubin Hancock Farmstead, 1880-1916

Table 1, continued

\begin{tabular}{|c|c|c|}
\hline Unit & $\begin{array}{l}\text { No. of } \\
\text { Levels }\end{array}$ & Depth (ft) Comments \\
\hline$\overline{\mathrm{E} 587+85 / \mathrm{N} 90}$ & 1 & $<0.5$ \\
\hline $\mathrm{E} 587+85 / \mathrm{N} 95$ & 1 & $<0.5$ \\
\hline $\mathrm{E} 587+90 / \mathrm{N} 125$ & 1 & $<0.5$ \\
\hline $\mathrm{E} 587+95 / \mathrm{N} 100$ & 1 & $<0.5$ \\
\hline $\mathrm{E} 588+00 / \mathrm{N} 140$ & 1 & 0.2 \\
\hline $\mathrm{E} 588+00 / \mathrm{N} 145$ & 1 & 0.2 \\
\hline $\mathrm{E} 588+00 / \mathrm{N} 150$ & 1 & 0.2 \\
\hline $\mathrm{E} 588+00 / \mathrm{N} 155$ & 1 & 0.34 \\
\hline E588+05/N60 & 1 & 0.05 \\
\hline $\mathrm{E} 588+05 / \mathrm{N} 130$ & 1 & $<0.5$ \\
\hline $\mathrm{E} 588+05 / \mathrm{N} 135$ & 1 & $<0.5$ \\
\hline $\mathrm{E} 588+05 / \mathrm{N} 140$ & 1 & $<0.5$ \\
\hline E588+05/N145 & 1 & $<0.5$ \\
\hline $\mathrm{E} 588+05 / \mathrm{N} 150$ & 1 & 0.2 \\
\hline $\mathrm{E} 588+05 / \mathrm{N} 155$ & 1 & $<0.5$ \\
\hline $\mathrm{E} 588+10 / \mathrm{N} 115$ & 1 & $<0.5$ \\
\hline $\mathrm{E} 588+10 / \mathrm{N} 130$ & 1 & $<0.5$ \\
\hline $\mathrm{E} 588+10 / \mathrm{N} 135$ & 1 & $<0.5$ \\
\hline $\mathrm{E} 588+10 / \mathrm{N} 140$ & 1 & $<0.5$ \\
\hline $\mathrm{E} 588+10 / \mathrm{N} 155$ & 1 & $<0.5$ \\
\hline $\mathrm{E} 588+10 / \mathrm{N} 160$ & 1 & 0.2 \\
\hline $\mathrm{E} 588+10 / \mathrm{N} 165$ & 1 & $<0.5$ \\
\hline $\mathrm{E} 588+15 / \mathrm{N} 145$ & 1 & $<0.5$ \\
\hline $\mathrm{E} 588+15 / \mathrm{N} 155$ & 1 & $<0.5$ \\
\hline $\mathrm{E} 588+15 / \mathrm{N} 160$ & 1 & $<0.5$ \\
\hline $\mathrm{E} 588+20 / \mathrm{N} 80$ & 1 & $<0.5$ \\
\hline $\mathrm{E} 588+20 / \mathrm{N} 100$ & 1 & $<0.5$ \\
\hline $\mathrm{E} 588+20 / \mathrm{N} 135$ & 1 & 0.36 \\
\hline $\mathrm{E} 588+20 / \mathrm{N} 155$ & 1 & $<0.5$ \\
\hline $\mathrm{E} 588+20 / \mathrm{N} 160$ & 1 & $<0.5$ \\
\hline $\mathrm{E} 588+25 / \mathrm{N} 40$ & 1 & $<0.5$ \\
\hline $\mathrm{E} 588+25 / \mathrm{N} 125$ & 1 & $<0.5$ \\
\hline $\mathrm{E} 588+25 / \mathrm{N} 160$ & 1 & $<0.5$ \\
\hline $\mathrm{E} 588+30 / \mathrm{N} 130$ & 1 & $<0.5$ \\
\hline $\mathrm{E} 588+30 / \mathrm{N} 145$ & 1 & $<0.5$ \\
\hline E588+30/N155 & 1 & $<0.5$ \\
\hline E588+35/N135 & 1 & $<0.5$ \\
\hline $\mathrm{E} 588+35 / \mathrm{N} 140$ & 1 & $<0.5$ \\
\hline $\mathrm{E} 588+35 / \mathrm{N} 150$ & 1 & $<0.5$ \\
\hline
\end{tabular}


Table 1, continued

\begin{tabular}{lccl}
\hline Unit & $\begin{array}{c}\text { No. of } \\
\text { Levels }\end{array}$ & Depth $(\mathrm{ft})$ & Comments \\
\hline E588+40/N15 & 1 & $<0.5$ & \\
E588+40/N60 & 1 & $<0.5$ \\
E588+40/N100 & 2 & $<0.5$ \\
E588+40/N120 & 1 & $<0.5$ \\
E588+45/N140 & 1 & $<0.5$ & \\
E588+45/N160 & 1 & $<0.5$ & \\
E588+55/N50 & 1 & $<0.5$ & \\
E588+55/N55 & 1 & $<0.5$ & \\
E588+60/N50 & 1 & $<0.5$ & \\
Trench 1 & n/a & 10.0 & no artifact recovery \\
Trench 2 & n/a & $<0.5$ & \\
Trench 3 & n/a & 2.75 & \\
\hline
\end{tabular}

E586+95/N175, and E586+90/N175. The last two units contained what was interpreted as a lithic cache. Other work completed during this final period included collection of five burned rock samples, seven matrix samples from a burned rock cluster, and soil samples from four different soil zones within unit E587+00/N175.

\section{SUMMARY OF PROJECT HISTORY}

From 1984 to 1987, personnel from SDHPT conducted work at 41TV875, the Rubin Hancock farmstead. Survey, testing, and data recovery were perfomed along with archival and oral history research. However, final analysis and report production remained unfinished. In 1998,
TxDOT contracted with Prewitt and Associates, Inc., to complete the analysis, report production, and curation requirements for the mitigation work at 41TV875.

The three research goals established in the data recovery research design (Clark 1985b) were pursued in the 1998-1999 analysis. The first goal, to study consumer access to local and national markets, is addressed from a historical perspective in Chapter 5, and directly in a discussion of consumer behavior in Chapter 6 . The second goal, to examine ethnicity and social status, also is addressed in Chapters 3, 5, and 6 . The third goal, to use artifact patterning to study culture, is the specific focus of a section of Chapter 6. 
The Rubin Hancock Farmstead, 1880-1916

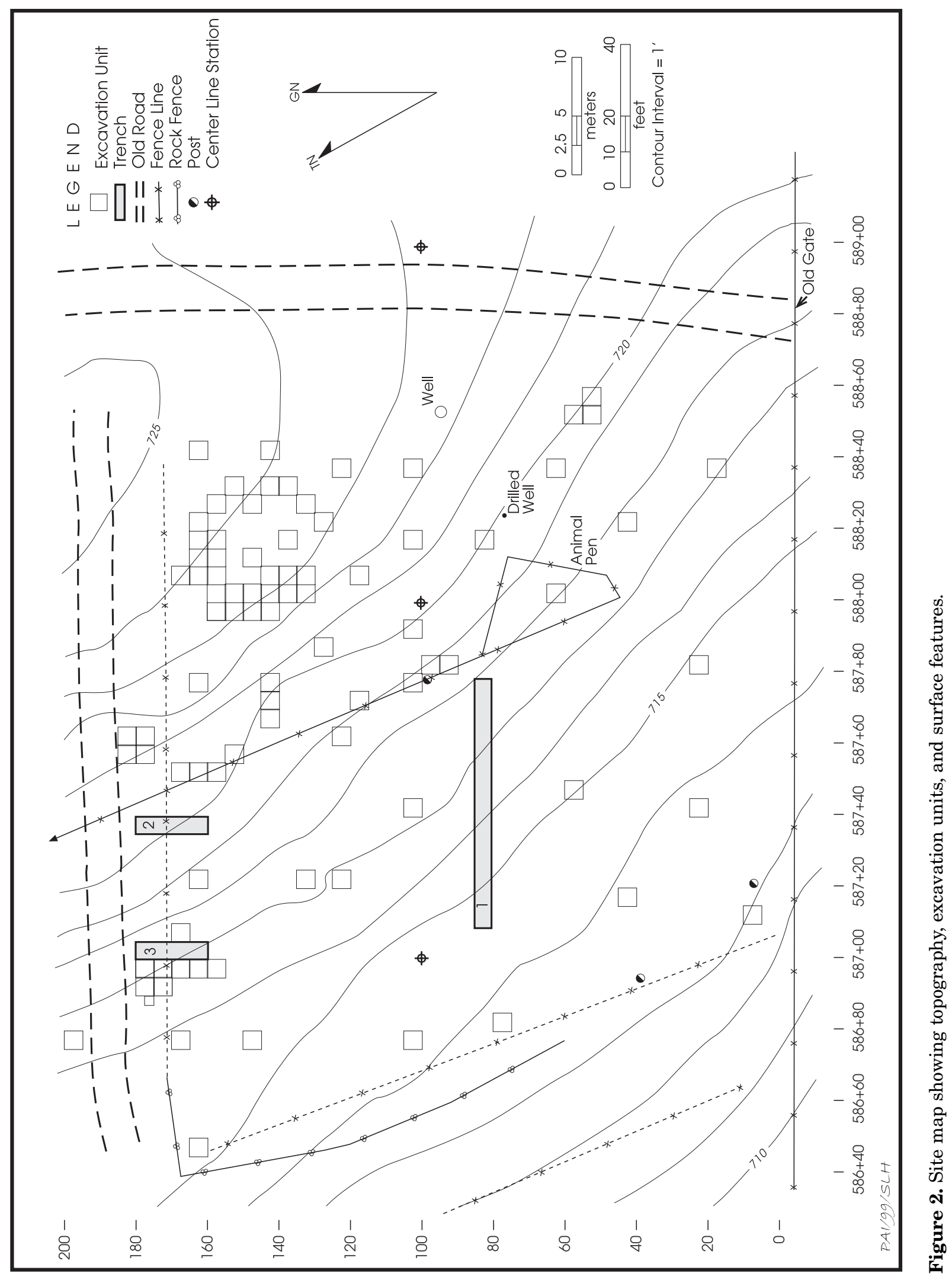




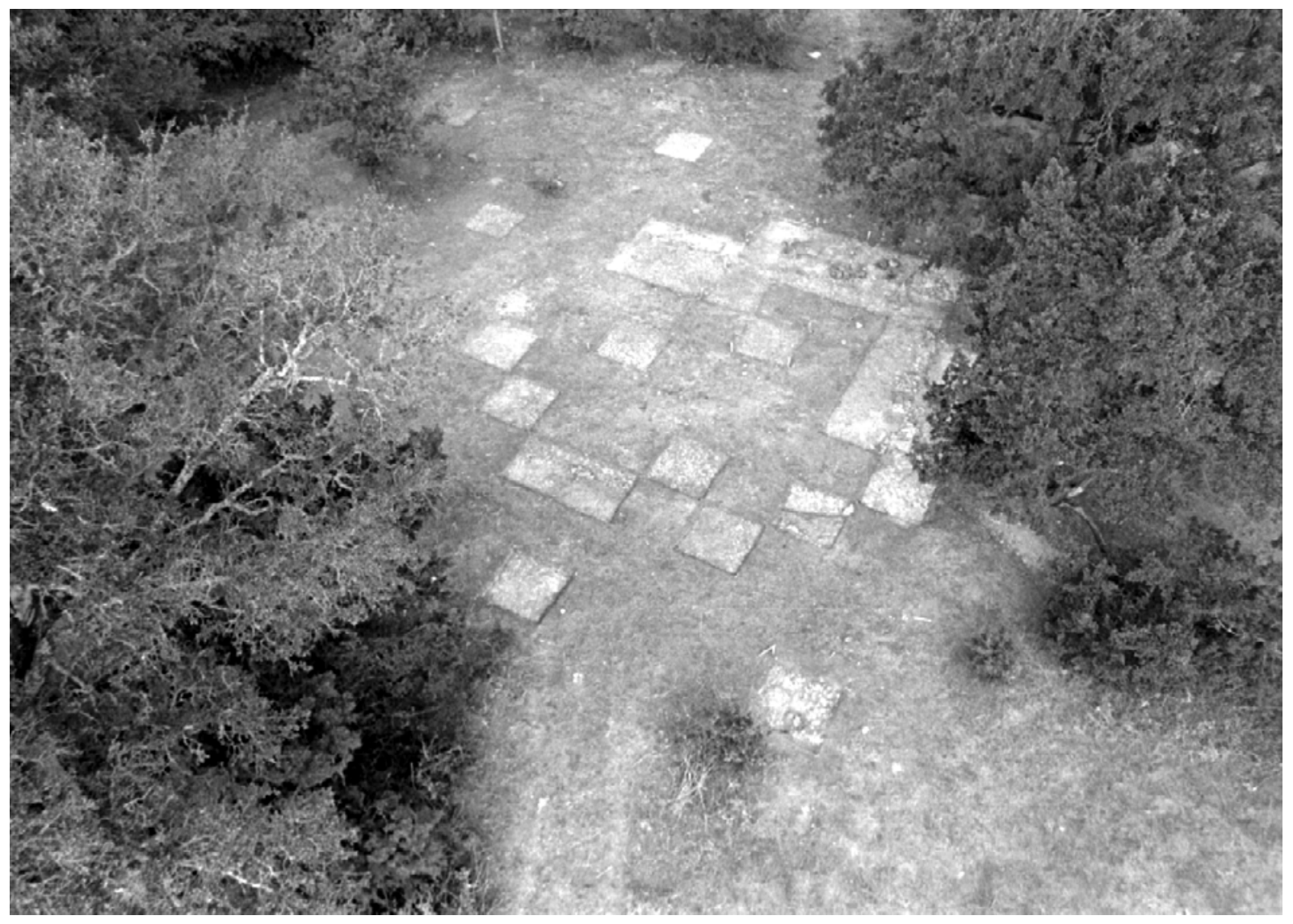

Figure 3. Excavations in the core historic area of 41TV875, facing grid west. 



\section{HISTORICAL BACKGROUND}

Rubin Hancock (also Ruben and Reuben) and his wife, Elizabeth (Figure 4), were among the first generation of emancipated slaves to acquire and farm their own land in Travis County following the American Civil War. With few resources beyond their own labor and the possible assistance of Rubin's former master, Judge John Hancock, the couple built a productive farm, raised a family, and helped establish a small but stable community of African American farmers in north-central Travis County, about 10 miles north of the 1880 Austin city limits. The collection of farms was centered roughly along present-day Duval Road between the small communities of Duval, a station on the I\&GN Railroad, and Waters Park, on the A\&NW Railroad. The enclave included about a dozen farms, most of whose owners were related to one another by blood or marriage, a school for African American children, and a Baptist church that endures to the present.

Few facts concerning Rubin and Elizabeth Hancock are certain. According to census and deed records, neither could read or write their own names. Even the traces of information about the couple recorded in early county records are often fragmentary, misleading, or contradictory. Nevertheless, more is known about Rubin and Elizabeth than about many anonymous former slaves in the postbellum period, primarily because they owned property and maintained their homestead for more than half a century. As a result, they are known through deed, census, tax, and probate records, as well as through their descendants, many of whom still live in the Austin area. The few written records that document their official activities in Travis County, together with oral histories gathered from their descendants, offer a glimpse into the lives of rural Travis County African Americans in the period following emancipation and into the early twentieth century.

\section{RESEARCH METHODS}

Initial research concerning the history of Rubin and Elizabeth Hancock and the farmstead at 41TV875 entailed a review of materials compiled by John W. Clark Jr. as part of TxDOT's work at 41TV875 and the nearby Waters Park community, including a draft report on the Waters Park research (Clark 1998). Mr. Clark collected a great deal of information about Rubin and his family, primarily from interviews with his descendants and neighbors.

Subsequent research included detailed census and tax record research spanning the period from 1870 to 1940 for the Hancocks, their extended family, neighbors, and other African Americans in the area. Census records on file at the Texas State Library and Archives and the Austin History Center helped identify or clarify relationships among people associated with the project area. In particular, information was gathered on Anderson Peoples, who was related to Rubin Hancock's wife and who amassed many of the land tracts in the Duval and Waters Park area for later resale to his extended family and other freed slaves. Austin Democratic Statesman articles on file at the Austin History Center dating from the 1870s containing references and articles about the Duval community also were reviewed.

Extensive research of deed records, ad valorem tax records, assessor's abstracts, and land grants was conducted at the Austin History Center, Texas State Library and Archives, and 


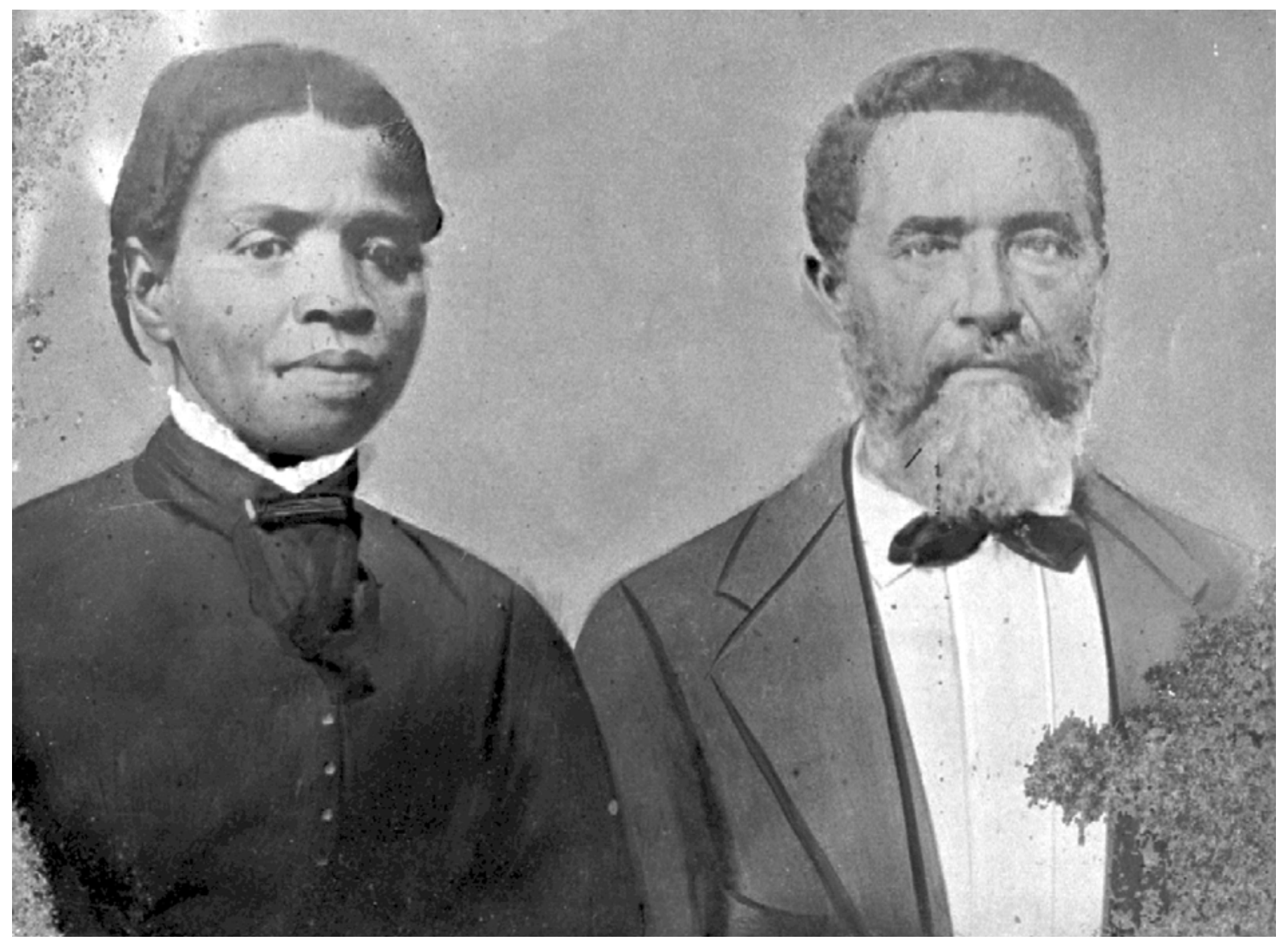

Figure 4. Elizabeth and Rubin Hancock. Photograph probably postdates 1889 but predates Elizabeth's death in 1899; courtesy of Lillian Robinson.

Texas General Land Office to augment Clark's earlier research. Gaps and clouds in the chain of title were clarified as much as possible through this research. In addition, several inconsistencies in the earlier research were resolved. Assessor's abstracts for the Thomas M. Fowler, James Rogers, and other nearby surveys were examined to trace land ownership over time. Ad valorem tax records extending from 1872 through 1940 provide land values for specific properties and other valuable information. Travis County tax plats on file at the Austin History Center include an 1880 plat of the town of Duval.

Vertical files and other sources at the Austin History Center provided background information on Judge John Hancock and his family. Agricultural census records (1850-1880) revealed significant information about farm ownership, products, and land values for both white and African American farmers in northcentral Travis County, including Rubin Hancock and his brothers. The 1860 slave schedules for John and George Hancock were among the most intriguing documents reviewed.

In addition to census, tax, and deed research, oral histories were undertaken to add to the existing information collected by Clark. Rubin Hancock's granddaughter, Mabel Walker Newton, and her niece, Eleanor Thompson, were interviewed and family photos obtained for inclusion in the narrative. The Reverend Jacob Fontaine III, a former minister and grandson of the organizer of St. Stephens Baptist Church (also St. Stephens Missionary Baptist Church and St. Stephens Church), provided the names of several people who had grown up in Waters Park. One of these, Mrs. Andrew Coleman, was interviewed as well. The Reverend Burnell J. E. McQueen, current pastor of the church, also was 
interviewed. Clark's original informants were not available for follow-up interviews; Lillian Robinson has passed away and Alma Mae Shelby could not be located. Other elderly members of the congregation could not be located or declined to be interviewed for this project. Karen Collins, who has conducted extensive research on the Martin Moore-John Hancock Farm in the present-day Austin neighborhood of Rosedale was interviewed on several occasions. She freely shared her research and written history of Judge Hancock's farm, as well as her personal collection of research notes, interviews, death certificates, and other information about Judge Hancock's slaves, including Rubin Hancock and his brothers.

Information about the Hancocks and their descendants and neighbors at Duval and Waters Park was compared with existing documentation of rural African American communities in central Texas during the same period. Research was conducted at the Austin History Center, the Carver Museum and Library, and the W. H. Passon Society for African American History. An Historical Outline of the Negro in Travis County (1940) by J. Mason Brewer, Travis County School records including The Defender (1936) and The Travis County School Annual: A Circular of Information (1905), and agricultural information including Haney and Wehrein's Social and Economic Survey of Southern Travis County (1916) were reviewed but found to be of little relevance to the African American communities at Duval and Waters Park. The archives and written materials produced by the Delta Sigma Theta Sorority were reviewed as well. With few exceptions, these sources concentrate on the history of African Americans within the city of Austin. An exception was found in Fontaine and Burd's (1983) book about Fontaine's grandfather's work organizing a network of Baptist churches in Austin and rural communities throughout Travis County in the late nineteenth century. This book was extremely helpful in identifying early residents of Waters Park and leaders in the St. Stephens Missionary Baptist Church.

\section{CHAIN OF TITLE: THOMAS M. FOWLER SURVEY LAND HISTORY}

The Rubin and Elizabeth Hancock farm- stead, an important part of the historic African American community of Duval-Waters Park in north-central Travis County, was carved out of the approximately 177-acre Thomas M. Fowler labor (Figure 5). The property had passed through several claimants and endured lengthy legal machinations before T. L. Wren secured title in 1880 and immediately resold the unimproved property to an African American, Anderson Peoples. Peoples in turn sold the land to former slaves, Rubin and Elizabeth Hancock, who were the first people known to have occupied the land and make improvements to it.

The Fowler Survey was the subject of conflicting claims of ownership before clear title was finally secured. Following the establishment of the Texas Republic, Thomas M. Fowler authorized Wilson Biggs to locate 1 labor of land (approximately 177 acres) on the east side of the Colorado River, to which he was entitled by virtue of Certificate No. 190, signed by the Board of Land Commissioners for Bastrop County on March 25, 1838. Bastrop County surveyor, Thomas H. Mays, surveyed "One Labor of Temporal land" on March 26, 1838, as recorded in Bastrop County (Bastrop County Deed Record D:346-347) and filed for record in Travis County on October 20, 1873 (Travis County Deed Record 48:235-236). The Fowler labor lay north of and adjacent to a 17-labor tract of land Mays had surveyed for James Rogers on February 22, 1838 (Texas. General Land Office 1888).

Fowler's claim soon was contested by Thomas Jefferson Chambers, a notorious and large-scale land speculator whose fluent Spanish had earned him a position with the Mexican government as surveyor general of Texas. He in turn acted as a paid agent on behalf of settlers in the Mexican state of Coahuila and Texas. According to his agent, Ira Lewis, Chambers was granted 8 leagues of land on the east bank of the Colorado River by the state of Coahuila and Texas on July 29, 1834. Lewis claimed that Chambers had the land located in what was then Bastrop County on June 20, 1835. Lewis then took the grant to the United States for safe-keeping, and by the time he returned in January 1840, other surveys, including Fowler's, had already been made on the land (Texas. General Land Office 1888).

In 1850, Chambers filed suit against Josiah 


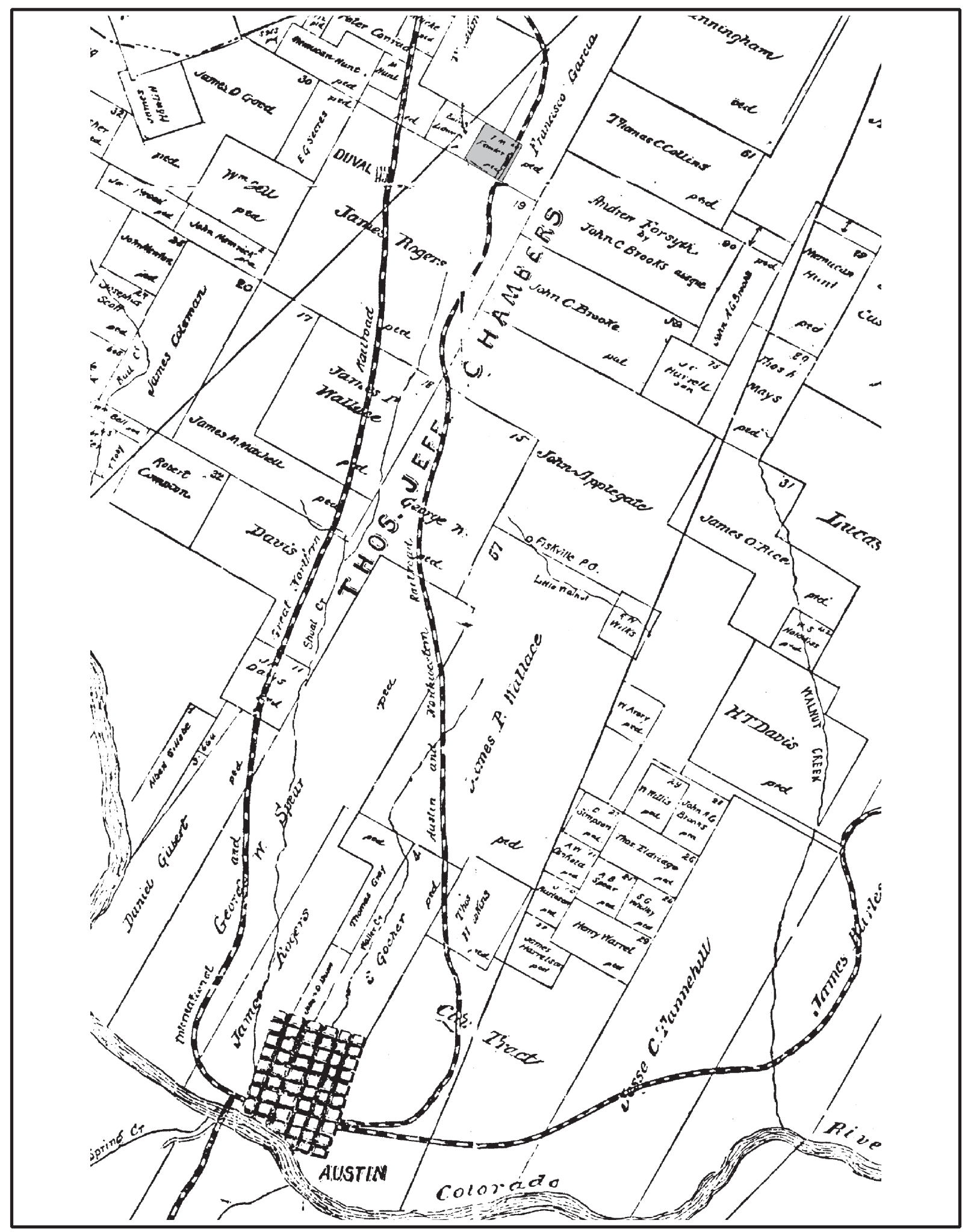

Figure 5. Map of part of Travis County, Texas, 1889. The Fowler Survey, on which Rubin Hancock's farm was located, is shaded. Courtesy of the Austin History Center, original on file at the Texas General Land Office. 
Fisk and 45 other settlers in the outlying portion of his 8-league grant. The case went through several trials before Judge O. M. Roberts remanded it for retrial. The Texas Supreme Court found in favor of the "Rights of Coahuila and Texas to its own land district," i.e., Chambers's grant was determined to be valid and therefore the superior title. Individual land owners held on for another 20 years before the suit finally was settled out of court. Some simply held on to their land through statutes of limitations. Finally, on September 11, 1888, the Court of Appeals officially awarded the Thomas M. Fowler patent to Wilson Biggs (Texas. General Land Office 1841, 1888), despite the fact that his heirs already had sold the property. Although other claims were made to the property, including one by John T. Harcourt, they too, were settled or dismissed, and Biggs's title remained intact. The T. J. Chambers Survey appears in dotted lines on the General Land Office's Travis County survey map in recognition of the claim.

By the time the Chambers conflict finally was cleared, Biggs had died leaving his widow, Celia Biggs, and children, John H. Biggs, David A. Biggs, Amanda Paschel and husband William, and Mary Gage, all of Nacogdoches, as heirs to the Fowler Survey. The Biggs heirs conveyed the entire 177-acre Thomas M. Fowler Survey to T. L. Wren of Austin in a special warranty deed dated November 16, 1880. Signed by all the Biggs heirs, the property was sold for $\$ 40$ cash (Travis County Deed Record 48:236-238). Wren promptly transferred the property to Anderson Peoples for $\$ 50$ cash and three promissory notes totaling $\$ 747.50$ to be paid within 2 years at 10 percent interest (Travis County Deed Record 48:239). The two transactions must have been negotiated concurrently because Wren had the deed to Anderson Peoples filed on December 17, 1880 (Travis County Deed Record 48:239-240), the same day the Biggs warranty deed and a proof of heirship were filed (Travis County Deed Record 48:238-239).

Anderson Peoples, possibly Elizabeth Hancock's brother or brother-in-law, appears to have been a broker of sorts for property within the Fowler Survey, and on January 1, 1881, Peoples and his wife sold 991/5 acres-"the North division of the T. M. Fowler Survey"-to Rubin and Elizabeth Hancock for $\$ 448.38, \$ 175$ cash and two promissory notes of $\$ 136.69$
(Travis County Deed Record 48:323-324). Later that year, both Hancock and Peoples conveyed a right of way through their adjoining properties to the A\&NW Railroad Company, which planned to build a rail line from Austin to Georgetown (Travis County Deed Record 52:40-42; 706:6364). Hancock lost about 4 acres of his farm to the right of way. In addition, the railroad separated a 12 -acre parcel on the east side of the tracks from the bulk of the Hancock property. In 1883, Rubin and Elizabeth sold the 12-acre parcel to Dorcas (also Dorkis) Gregg (Travis County Deed Record 58:452), a woman who also may have been Judge John Hancock's slave and Rubin's relative. Of the original 99 1/5acre parcel purchased from Peoples, about 83 acres remained. This parcel is the property historically associated with Rubin and Elizabeth Hancock. Except for a brief period just before his death in 1916, Rubin Hancock lived on his farm the rest of his life. The land remained the property of the Hancock heirs until Rubin and Elizabeth's last surviving daughter, Susie Dickerson, sold it in 1942.

\section{THE RUBIN AND ELIZABETH HANCOCK FAMILY}

Rubin Hancock was born a slave in Alabama about 1835 and was about 30 years old when he gained his freedom in 1865. Rubin already was married or otherwise committed to his lifelong mate, Elizabeth (born about 1846 in Tennessee), by that time, but no Travis County marriage records confirm the date or details. Though family life generally was encouraged for social stability and reproduction, slave marriages were not recognized legally in Texas (Campbell 1996:1082). As a result, they were not documented in county records before 1865 . Rubin and Elizabeth had at least one, and possibly two, of their five children by the time they were set free (Figure 6). Susie was born in 1865, and Melvina, who is thought to have been the oldest, was probably a few years old by then. About 1867, the couple's only son was born. Although his name is listed as Charley in the 1880 census, later affidavits and descendants identified the only Hancock son as John. Fannie was born about 1869, and Martha (Mattie), the youngest, about 1871 (Figure 7). Rubin and all of the children except the oldest child, Melvina, who probably was married to Charlie Smith and 
The Rubin Hancock Farmstead, 1880-1916

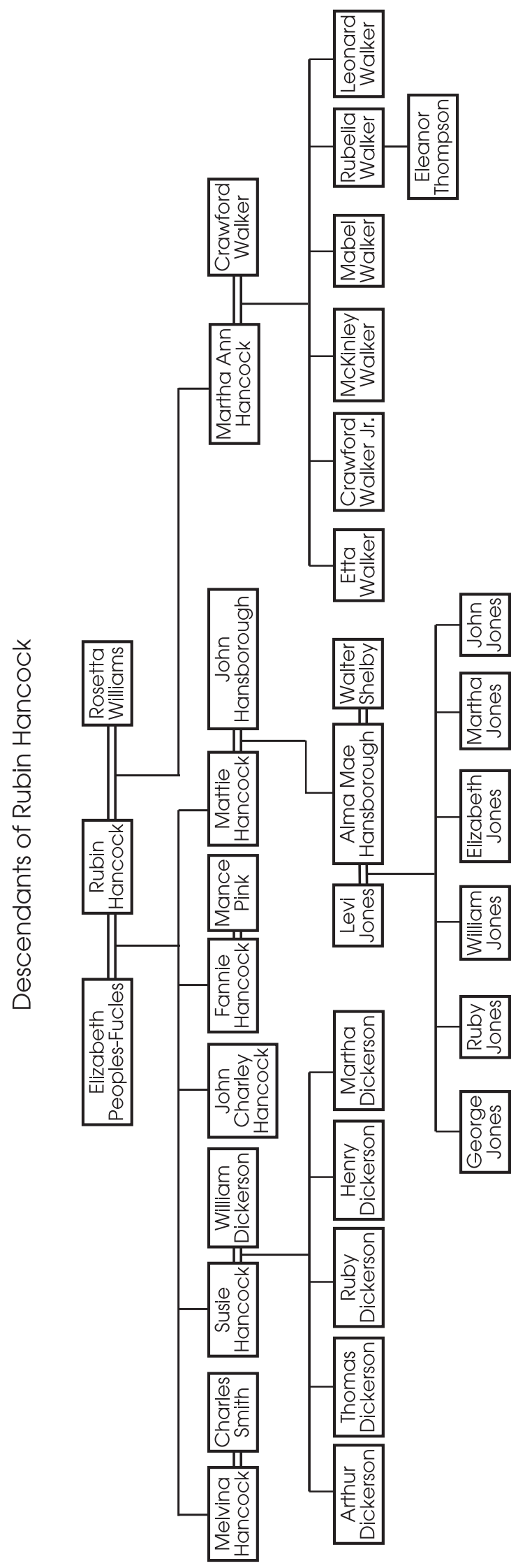

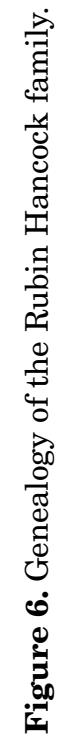




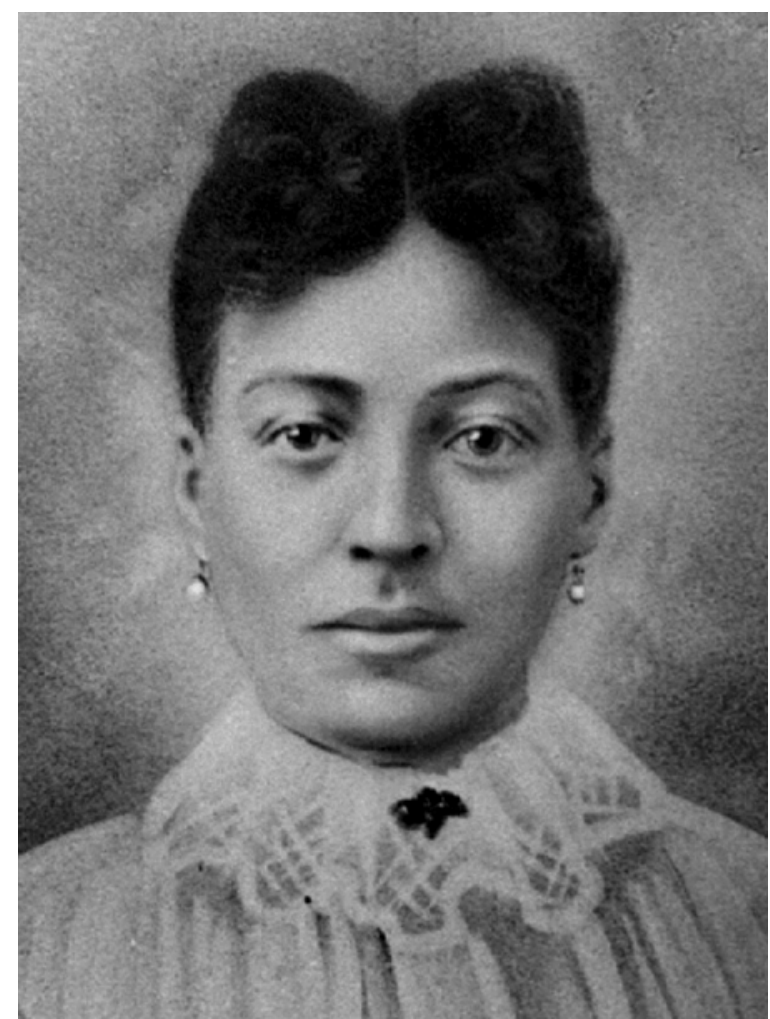

Figure 7. Mattie Hancock Hansborough. Courtesy of Lillian Robinson.

no longer living in the household, were represented as mulattos in the 1880 census, while Elizabeth was designated "B" for black.

In 1877, Rubin fathered another child, Martha Ann Hancock, with a woman named Rosetta Williams. Rosetta Williams may have lived near the Hancocks when Martha Ann was born, but she moved to Rogers Hill in Imperial Valley, a rural community in eastern Travis County, about 1886 . As a young child, Martha Ann (Figure 8) lived part of the time with her mother at Rogers Hill and part of the time with her father. She was treated as a member of the Hancock family and enjoyed good relationships with her father, Elizabeth, and her half-sisters, particularly Mattie, who was closest to her in age. She maintained close ties to her father and half-sisters throughout their lives (Newton 1999).

Rubin probably was living with his wife and children in Travis County throughout the 1870s. He was listed along with his three brothersPeyton, Salem, and Orange-among the "colored" registered voters of Travis County in the period 1867-1872, and in 1873 they were listed one after another on a voter registration list for Travis County's Precinct 17, as if they registered as a group (Collins 1999a). Like his brother Orange, Rubin and Elizabeth may have lived on the farm of Rubin's former master Judge John Hancock for a while after emancipation. It is possible that they worked for wages as farm laborers or were tenant farmers or sharecroppers.

The family had moved to the Thomas M. Fowler Survey sometime before 1880. Although the deed was not transferred until January 1 , 1881, Hancock and his family appear to have been living on the property when the 1880 census was taken. According to the agricultural schedule, Hancock rented his land for shares of the products. In other words, he was a sharecropper before he purchased his farm. It is not known how long Hancock occupied the land before he purchased it in 1881, but it was

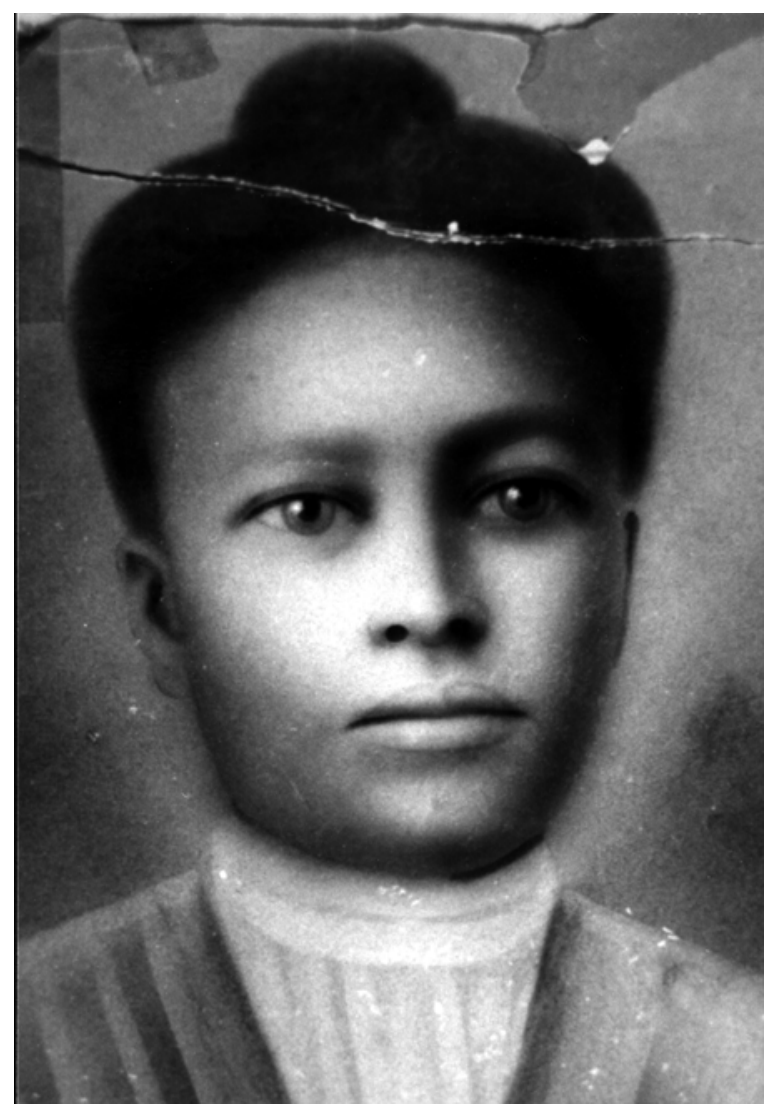

Figure 8. Martha Ann Hancock Walker, ca. 1896. Courtesy of Eleanor Thompson. 
probably not more than a year or two.

Between 1880 and 1900, Rubin and Elizabeth's daughters Susie, Fannie, and Mattie all married and started families of their own. Fannie married Mance Pink and moved to Mitchell County, but Susie and Mattie stayed close to their parents and the community in which they were raised. Susie married William (Bill) Dickerson, whose family had lived on Judge John Hancock's dairy farm in the presentday Rosedale neighborhood in Austin (near Burnet Road and 45th Street). Susie and Bill Dickerson lived near her husband's family for a while, but they also had a farm southwest of Rubin and Elizabeth's homestead (Shelby 1987). The couple had five children: Arthur, Thomas, Ruby, Henry, and Martha Dickerson Latson. Mattie Hancock married a man named Mack Oliver whom she later divorced before marrying a widower, John Hansborough. In 1896, Rubin's youngest daughter, Martha Ann, married a prosperous widower named Crawford Walker and went to live at his farm at Imperial Valley, between Austin and Webberville (Thompson 1999).

Despite their relative good fortune with the farm, the Hancocks experienced several tragedies during this period. The couple's only son, John, died about 1886 at the age of 21 . Their oldest daughter, Melvina, lost both of her children in early infancy. Then, both she and her husband died sometime before 1899. Finally, Elizabeth died in 1899-reportedly of tuberculosis-leaving Rubin alone at the homestead.

By 1900, Rubin was alone and in his sixties, and he probably required help running his farm. Despite his advanced years and presumed slower pace, Rubin apparently continued to work the farm, and its tax value increased from $\$ 1,000$ in 1900 to $\$ 2,400$, in 1910 . He had a network of family and friends nearby to help him.

Informant Mable Walker Newton (1999), who was Rubin's granddaughter, remembered Rubin's farm during the late period of his life. She visited there as a small child. She described his home as a comfortable house with two rooms under the main roof. The house was made of logs and it had lumber siding. The kitchen was a shed-type addition to the house that was not under the same roof. The kitchen had a flue for the stove. One room was the living room, which was where the fireplace was located. Newton remembered that both rooms had big windows, one in each room. The windows had glass with wooden shutters that could be closed over them. The garden on Rubin's farm had a fence around it to keep the chickens out. About 1904, John Hansborough purchased a 561/2-acre farm tract in the Francisco Garcia Survey which lay adjacent to and north of his father-in-law's farm. Rubin Hancock had once owned the property but sold it to N. S. Walton in 1892 (Travis County Deed Record 113:190). Hansborough purchased the farm from the Walton Estate after his first wife died, and he and Mattie lived across the road that divided their property from Rubin's. In 1909, the couple had one child, Alma Mae, who lived on her parents' farm until she was about 22 years old. Rubin's daughters Susie and Martha Ann also traveled to the Hancock farm regularly to visit their father and care for him when necessary (Newton 1999).

Long-time Waters Park resident Lillian Robinson recalled that Fannie Hancock, the wife of Salem Hancock's son Richard, took care of Rubin in his last years. Finally, when he got too old to live on his own, Rubin moved in with his daughter Susie and her family, who lived near the School for the Deaf at that time. Rubin died in 1916 and was buried next to Elizabeth at St. Paul's Cemetery in the St. Johns area near the old A\&NW Railroad crossing at Ohlen Road (Newton 1999; Robinson 1987; Shelby 1987). Shortly after her father's death, Susie and William Dickerson moved back to the farm where they lived at least part of the time until William's death in 1938.

In his will (Travis County Probate File 4499), Hancock divided his property among his and Elizabeth's three surviving daughters: Susan (Susie) Hancock Dickerson, Fannie Hancock Pink, and Mattie Hancock Hansborough. The parcels were of unequal size but comparable value. Sometime between 1902 and 1909, a subdivision of Hancock's property was made in which the 83 -acre homestead was divided into three tracts. The north tract contained the 10-acre housesite, while the other two tracts each contained 36.5 acres. After their father's death, Mattie and her family obtained the northernmost 10 acres of land, and Susie and her husband apparently owned the remaining 73 -acre farm. They appear to have maintained another home on the Dickerson 
property near the Rosedale neighborhood as well. There is no record to show that the Dickersons purchased Fannie Hancock Pink's share of Rubin's legacy, but Susie had acquired the property by 1920 when she paid taxes on the full 73-acre parcel (Travis County Assessor's Abstract of Land 1920).

Susie and Bill Dickerson and Mattie and John Hansborough continued to pay taxes on their farm property throughout the 1920s and 1930 s, but both families apparently gave up active farming in the $1930 \mathrm{~s}$. Although they continued to claim their farm property as their homesteads in the 1930-1940 county tax records, they no longer lived on their farms. Mattie died about 1935 and John Hansborough moved into Austin. According to their addresses in the 1935 tax records, Susie and Bill Dickerson had moved to Austin as well.

On February 2, 1942, Susie Dickerson conveyed 73 acres of the Hancock family farm to Earl and Flossie J. Gregory for $\$ 2,200$ (Travis County Deed Record 700:487-488). Mattie Hancock's 10-acre parcel was not part of the transaction, but the Gregorys subsequently acquired that parcel from Charlie Hays (Travis County Deed Record 728:160), who apparently obtained it from John Hansborough after Mattie's death. Thus, Rubin Hancock's original 83-acre farmstead was reunited under ownership by the Gregorys. They eventually conveyed the farm tract, along with the 561/2-acre parcel out of the Francisco Garcia Survey that once belonged to John and Mattie Hansborough, to J. W. Yett Jr. and his wife, Rose, in 1954 (Travis County Deed Record 1487:173).

According to Alma Mae Hansborough Shelby (1987), Rubin's house was moved into "town" in 1942, about the time the property was sold out of the family. Susie and John died shortly after the farm was sold. Martha Ann Hancock Walker, Rubin Hancock's youngest and last surviving child, died in Austin in 1955 (Thompson 1999). By that time, none of Rubin Hancock's descendants remained in the Waters Park area.

\section{ORIGINS OF THE RUBIN HANCOCK FAMILY IN TRAVIS COUNTY}

The earliest information about Rubin Hancock, his family, and the community that eventually grew up near his farm may be found in the history of Judge John Hancock, a prominent Austin lawyer, plantation owner, and legislator whose career and influence in Travis County spanned five decades. Hancock's parents, John Allen and Sarah Ryan Hancock, were originally from Virginia. They moved to Tennessee in the early nineteenth century and in 1819 to Alabama, where John was born in 1824.

Hancock studied law in Tennessee and moved back to Alabama where he was admitted to the bar in 1846. The following year, he joined his brother, George, in Texas. George had come to Texas in 1835 to join the fight for independence from Mexico. After the war, George worked as a surveyor, locating lands and acquiring substantial real estate in the new Republic. He also established himself as a successful merchant in Bastrop County before opening a store in Austin about 1845. He probably encouraged his younger brother to take advantage of the opportunities available to him in Texas.

John Hancock began his law practice as soon as he arrived in Austin and was elected judge of the Second Judicial Court in 1851, at the age of 26 (Lynch 1885:422); he also established one of the Austin area's largest farms. His initial holdings in the Spier League lay about 4 miles north of Austin, west and north of the present-day Rosedale subdivision near Burnet Road and 45th Street (Collins 1999b). By 1860 , his property included 20,000 acres of unimproved land and 300 acres of improved land. The cash value of the farm was $\$ 15,000$, and Hancock also owned $\$ 1,000$ worth of machinery and farm implements (U.S. Bureau of the Census 1860). Although Judge Hancock grew wheat, rye, oats, barley, and other crops on his property, his contemporaries considered it primarily a stock farm (Lynch 1885:422). According to the 1860 agricultural schedule, Hancock owned 11 horses, 4 asses and mules, 18 milch cows, 12 working oxen, 25 other cattle, and significantly more sheep (109 total) than any other farmer or rancher in the area. He also produced 1,200 pounds of butter and valued the worth of his slaughtered animals at $\$ 800$ (U.S. Bureau of the Census 1860). In total, Hancock's real estate was worth $\$ 60,000$ and his personal property was valued at $\$ 25,000$, making the judge one of the county's wealthier farmers in 1860 (U.S. Bureau of the Census 1860). 
In addition to his other "property," the 1860 census shows that Hancock owned 21 slaves. According to Rubin Hancock's descendants, he, along with his brothers, sisters, and mother, were brought to Texas with John Hancock (Shelby 1987). Since John Hancock was a young, unmarried man of 23 when he traveled to Texas in 1847, it is possible that his father, John Allen Hancock, gave the slaves to him to clear and work the land he intended to settle in his new home. However, ad valorem tax records list only 1 slave in Hancock's possession from 1848 to 1850 , and only 2 in 1851 . More slaves may have followed later, but it also is possible that they were not correctly tallied in the tax records. In any case, Hancock's tax records show a steady increase in the number of slaves he owned in the years following his arrival in Texas. He claimed 7 slaves in 1853, and 10 in 1855 . In 1856 , the number jumped to 19 , and by 1858 it increased to 24 . In 1860 , just before the Civil War, Hancock was shown to have only 15 slaves, but that number increased to 24 the following year. For the last 3 years of the war, 1863-1865, Hancock owned 25 slaves worth a total of $\$ 11,250$ (Texas. Ad valorem tax records 18481865).

Rubin Hancock and his brothers-Orange, Salem and Peyton-were almost certainly among the slaves listed in the 1860 census and in the later tax records. A narrative by Orange's daughter Emma states that her father was John Hancock's slave (Weeks 1937), and strong family traditions maintain that the other brothers were as well (Newton 1999; Shelby 1987). Census records show a variety of connections both among the brothers and between the brothers and their former owners and their families, including the use of family names and birthplaces. It is likely that all four brothers worked and lived on Judge Hancock's farm.

One of the unsolved questions about Rubin and his brothers concerns their parentage, for which there are conflicting accounts. A number of the Hancock slave descendants claim that John Hancock fathered their grandparents or great-grandparents. Orange Hancock's greatgrandson, Frank Wicks, stated that John Hancock was Orange's father (Collins 1999a), and Rubin Hancock's granddaughter, Mabel Walker Newton, said that it is common knowledge in her family that John was Rubin's father (Newton 1999). Another member of the
African American community at Waters Park, Lillian Daniels Robinson, told researchers that her mother, Sophie Hancock Daniels, was Judge John Hancock's daughter by his slave, Omi Roy (Robinson 1987). However, one of Rubin Hancock's granddaughters, Alma Mae Hansborough Shelby, indicated that Rubin and his brothers were Judge Hancock's halfbrothers. Given their ages-John Hancock would have been only 13 when Orange was born, between 11 and 14 when Rubin was born, and only about 6 years old when their brother Salem was born-this is the more likely case. In addition, John Hancock's father also was named John (John Allen Hancock), and that may have caused some misinterpretation in retelling the family history. Another item that favors John Allen Hancock as the father is found in census records covering the years $1870,1880,1900$, 1910 and 1920, in which Rubin, Orange, Salem, and Peyton consistently list their father's birthplace as Virginia. Judge John Hancock was born in Alabama while his father, John Allen, was born in Virginia.

Judge Hancock's large land holdings would have required substantial labor to keep them in production. Few improvements had been made to his property in the Spier League before he acquired it in the late $1840 \mathrm{~s}$, but between 1853 and 1854 he built a log house and made other improvements (Collins 1999c). His slaves, including Rubin and his brothers, probably began the hard work of clearing the land soon after they arrived in Travis County and most likely continued improving the property until they were freed in 1865. It would have taken years to clear, prepare, and plant the 300 acres of productive fields listed in the 1860 census. Therefore, the slaves most likely built the houses, cabins, barns, sheds, fences, and outbuildings necessary to support Hancock's household, slaves, and stock. By 1860, Hancock had 21 slaves occupying five slave houses which were probably all on this farm.

Despite his reliance on slavery, John Hancock was an avowed Unionist and vocal in his opposition to secession. In fact, Hancock was elected to the Texas legislature as a Unionist in 1860. The following year, after Texas joined the secessionists, Hancock refused to pledge his allegiance to the Confederacy and was removed from office. He continued to practice law in the state courts throughout most of the war. One of 
his most famous cases occurred in 1863, during the height of the war. It involved saving a wealthy Brazos River planter, Dr. R. R. Peebles, from being lynched by a mob who thought he had conspired to spread sedition about the Confederacy. Hancock jeopardized his own safety and reputation by invoking a writ of habeas corpus to remove Dr. Peebles from an unsecured prison and have the charges against him dropped. Hancock himself was forced to flee Texas for Mexico the following year when he was threatened with compulsory military service in spite of his strong antisecession sentiments. From Mexico, Hancock made his way back to the United States where he remained until the end of the war (Lynch 1885:425).

When he returned to Austin, Hancock resumed his law practice and continued to operate his farm, now with hired rather than slave labor. Shortly after the war, Hancock purchased the 521-acre Martin and Elizabeth Moore farmstead adjacent to his land in the Spier League, and his combined holdings contained about 4,000 acres. The Moores had built a log house, outbuildings, and fences on the site, and by the time Elizabeth Moore sold the farm to Hancock, it was worth close to $\$ 10,000$ (Collins 1999c:25). According to Orange Hancock's daughter, Emma, her father worked for Judge Hancock on a wage basis for a time after emancipation. Karen Collins (the present owner of the Moore-Hancock farmstead, with her husband, Mike) believes that Orange and his wife Rhody lived in the Moore log house for about 4 years before leaving Judge Hancock (Collins 1999c:25).

Although some of Hancock's white descendants claim that he freed his slaves before emancipation (Collins 1999d), no records to that effect have surfaced. Because Hancock's slaves were inventoried as his property for tax purposes for the year 1865 (Texas. Ad valorem tax records 1848-1865), they probably remained enslaved until June 19, 1865, when emancipation was announced throughout Texas. Nothing further is known about Hancock's other slaves and their response to freedom, but many ex-slaves remained with their former masters for some time after emancipation. Hence, it is possible that Rubin and the others may have spent some time on the Hancock farm before striking out on their own. Several of Rubin
Hancock's descendants have stated that Judge Hancock helped Rubin and his brothers start farms of their own after emancipation (Newton 1999; Thompson 1999), but like many other aspects of their history, no documentation has been found to verify his assistance.

What little is known about the lives of the Hancock brothers as slaves comes from a single account recorded in a 1937 Work Projects Administration (WPA) interview with Orange Hancock's daughter, Emma Hancock Weeks. A few additional pieces of information about this period come from family stories obtained from Rubin Hancock's descendants in oral interviews conducted between 1987 and 1999, but Emma Weeks's is the only first-hand account.

Emma Hancock Weeks was about 80 years old when she was interviewed as part of the WPA effort to collect histories from the dwindling numbers of former slaves. Alfred E. Menn conducted many slave narratives in central Texas and interviewed Emma at the small home she shared with her son, Frank Weeks, at 2203 Washington Avenue in Austin in October 1937. Menn's attempt to record her manner of speech, a characteristic common to the WPA slave narratives, is an awkward although well-intentioned effort to preserve a dying folk language.

In her narrative, Emma Hancock Weeks related her childhood memories of life as a slave, of emancipation, and her family's struggle to build a farm in north-central Travis County. Emma stated that her father, Orange Hancock, was Judge Hancock's slave, and she identified the mistress's name as Sue. John Hancock's wife was the former Susan E. Richardson. Emma recalled that her father always called his master "Judge." Orange Hancock was a field worker on Judge Hancock's cotton plantation. He also was a skilled blacksmith and stockman. Emma's mother, Rhody, was a house slave of Jim and Patsy Hollman, who owned a cotton plantation near Judge Hancock. Rhody cooked and performed housework and apparently lived with her children at the Hollman house. Emma mentioned that she slept in a little bed outside her mistress's room and indicated that the slave quarters were some distance from where she lived. The Hollmans appear to have owned members of an extended family because Emma mentioned that her grandfather, Jesse Hollman, acted as an overseer on the Hollman plantation. 
With different masters, Rhody and her children lived apart from Orange, but he was allowed to visit her on Wednesday and Saturday nights. Emma was born on the Hollman plantation about 1858, but she did not know her exact birth date (Weeks 1937:363-366).

Emma's recollections of slavery probably were influenced by the fact that she experienced it as a child and was not required to perform hard work. She was only about 8 years old when the institution was abolished in 1865. According to her narrative, both her elderly master and his wife indulged and spoiled her. She had fond memories of the Hollman daughters and grandchildren, as well. The Hollmans' granddaughters played with Emma and sewed new clothes for her. Once when she neglected her duties and stole into town with the master, her mistress scolded her but forbade Rhody from punishing the little girl. Emma's primary responsibilities were to assist her mistress and bring her cool water from the spring (Weeks 1937).

Although she did not recall the day she was set free, she did remember the day that her father came to the Hollman plantation to collect Rhody and her children, and she surmised that it was emancipation day. Following emancipation, Orange Hancock took his family back to his cabin on the Hancock place where he then worked for monthly wages for a time. While there, Emma and her mother occasionally visited their former mistress, by then a widow (Weeks 1937:367).

Their lives changed significantly when they moved from the plantation and went to work on the Davis farm, about 2 miles north of the Hancock place. Orange Hancock apparently worked as a tenant farmer or sharecropper; Emma recalled that Davis had several renters. Field work was hard enough for adults, but now the children were needed to chop and pick cotton and to chop corn to sustain the family. The most noteworthy "product" of the Davis farm, to Emma, was the number of rattlesnakes. Although she felt that she handled the field work well, Emma stated that she could never pick more than 150 pounds of cotton a day, for which she was chastised by her sister (Weeks 1937:368).

The family's occupation as sharecroppers or tenant farmers probably was similar to that of other emancipated slaves in central Texas at that time. The majority of rural African
Americans listed in the 1870 and 1880 Travis County census returns worked as farmers or farm laborers who rented, rather than owned, their homes and farms. Emma did not recall how long the family worked on the Davis farm, but it was "a long time" before her father bought some "ungrubbed and unfenced" land (Weeks 1937:368). This apparently refers to the farm that Orange Hancock and his family occupied by 1877 in north-central Travis County, in the vicinity of what later would become the DuvalWaters Park community.

\section{AFRICAN AMERICAN SETTLEMENT IN NORTH-CENTRAL TRAVIS COUNTY AFTER THE CIVIL WAR}

Before the Civil War, the part of Travis County more than a mile or two north of Austin was characterized by large tracts of sparsely settled land. Self-sufficient pioneers farmed some of their acreage, but much of the land remained in its natural state until after the war (Clark 1998:41). Agricultural census data from 1850-1870 show that more-intensive cultivation was under way in eastern Travis County in the vicinity of Webberville and Hornsby Bend, while northern Travis County was largely vacant or grazing land during that period.

After the war, many of the large landowners in the north-central part of the county began carving up their holdings for sale to the many new arrivals to Texas. New farms filled in the gaps between the previously far-flung homesteads along the major roads leading north toward Williamson County. During this time, African Americans began buying small parcels of farmland along Upper and Lower Georgetown Roads, diverging paths proceeding north from Austin to the Williamson County seat of Georgetown. These roads generally followed present-day Burnet Road (FM 1325) and North Lamar Boulevard, respectively.

All four Hancock brothers and several families related through marriage and/or servitude on the Hancock plantation established homesteads north of Austin in the decade following emancipation. According to family tradition, John Hancock purchased farms for his "mixed race" children and former slaves so they could get started in life (Newton 1999). This has not been confirmed in any official documents, however. All of the Hancock brothers-Salem, 
Rubin, Orange, and Peyton-purchased land in a narrow band lying north of Hancock's plantation on either Upper or Lower Georgetown Roads. Although not adjacent, their farms lay fairly close, within a few miles of one another.

Salem Hancock, the oldest of the brothers, is the first known to have owned his own land in Travis County. In 1871, Salem purchased a 5 -acre parcel including a house "on the West side of the Georgetown road-North of William Robinson's place," only 6 years after emancipation. He paid Harriet McKenzie $\$ 500$ "in coin" for the property (Travis County Deed Record W:707-708). Although it was small, the property lay in both the George W. Davis and the J. P. Wallace Surveys (Figure 9), straddling Georgetown Road (Travis County Deed Record $\mathrm{W}: 707-708$ ).

Salem already may have been farming in the area by the time he purchased the land and house. The agricultural census of 1870 shows that Salem rented a 45 -acre parcel of improved land near the Davis and McKenzie families. On this tract, Salem produced 600 bushels of Indian corn and raised some stock including 2 horses, 2 working oxen, 7 milch cows, and 10 swine valued at $\$ 200$. His cows produced enough milk to make 96 pounds of butter. The estimated value of all his farm production that year was only $\$ 90$ (U.S. Bureau of the Census 1870a). By 1874, Salem had increased his 5-acre farm to 12 acres, and by 1877 , he owned $271 / 2$ acres, all within the G. W. Davis survey, valued at $\$ 545$ (Texas. Ad valorem tax records 1874-1877). Both Judge John Hancock and his brother, George, owned land in the same survey, and it is possible that one or the other assisted Salem in purchasing his farm. None of his brothers appears in the 1870 agricultural census, and it is probable that they were working for others at that time. Within a decade of his first land purchase, however, Salem's younger brothers Rubin, Orange, and Peyton, and several other family members, all bought land in northern Travis County.

One of these family members, Anderson Peoples, purchased 12 acres of land in the James Rogers Survey, farther north near the future community of Waters Park. Peoples bought the land from Garland Colvin and his wife, Ellen, for $\$ 300$ (Austin Democratic Statesman, 26 March 1876:3; Travis County Deed Record 31:498). The Colvins had received the land from Ellen's father, Silas Summers, who was one of the earliest settlers in northern Travis County. The land adjacent to his home along Walnut Creek originally was known as Summers Grove, later renamed Waters Park (Clark 1998:45).

The Summers-Colvin parcel is the first recorded land sale in the area to Peoples, who was the first African American known to purchase land in the Waters Park region (Travis County Deed Record 31:498). Peoples's purchase was significant because he attracted other African Americans, many of whom were former Hancock slaves, to the Duval-Waters Park area. He acted as a broker in that he bought up large parcels in the Thomas M. Fowler and James Rogers Surveys and then resold smaller tracts to other African Americans. Peoples and his wife, Martha, also were instrumental in establishing St. Stephens Missionary Baptist Church, an institution that helped create a sense of community for the African American families in the area.

In 1877, Peyton Hancock, the youngest of the four Hancock brothers, purchased 50 acres of land from R. A. Rutherford for $\$ 750-\$ 200$ in cash and the rest in promissory notes payable by January 1879 . According to his deed, the parcel was located in the John Applegait (also spelled Applegate) Survey on the Austin and Georgetown Road, depicted as Lower Georgetown Road on later maps, 8 miles north of Austin (see Figure 9). The land was adjacent to a league of land that Rutherford had sold to George Casine (also spelled Kissine and Cassini), another African American farmer (Travis County Deed Record 55:29-30). Casine's wife, Minnie, may have been related to Peyton since her mother, who lived in the Casine household, was Susan Hancock (U.S. Bureau of the Census, 1870b, 1880a). Rutherford earlier had sold land in the same area to Henry Dickerson, another former slave, possibly of John Hancock or a neighbor, in 1873 and 1874 (Travis County Deed Record 55:29). Although Peyton Hancock's farm was not considered part of Waters Park or Duval, it was still fairly close to those communities and within 5 miles of John Hancock's farm.

A few years later, on January 4, 1882, Peyton expanded his farm by purchasing another 72 acres of land adjacent to his original parcel. The new farm cost $\$ 1,080-\$ 360$ cash and the rest in promissory notes to be paid by January 1 , 


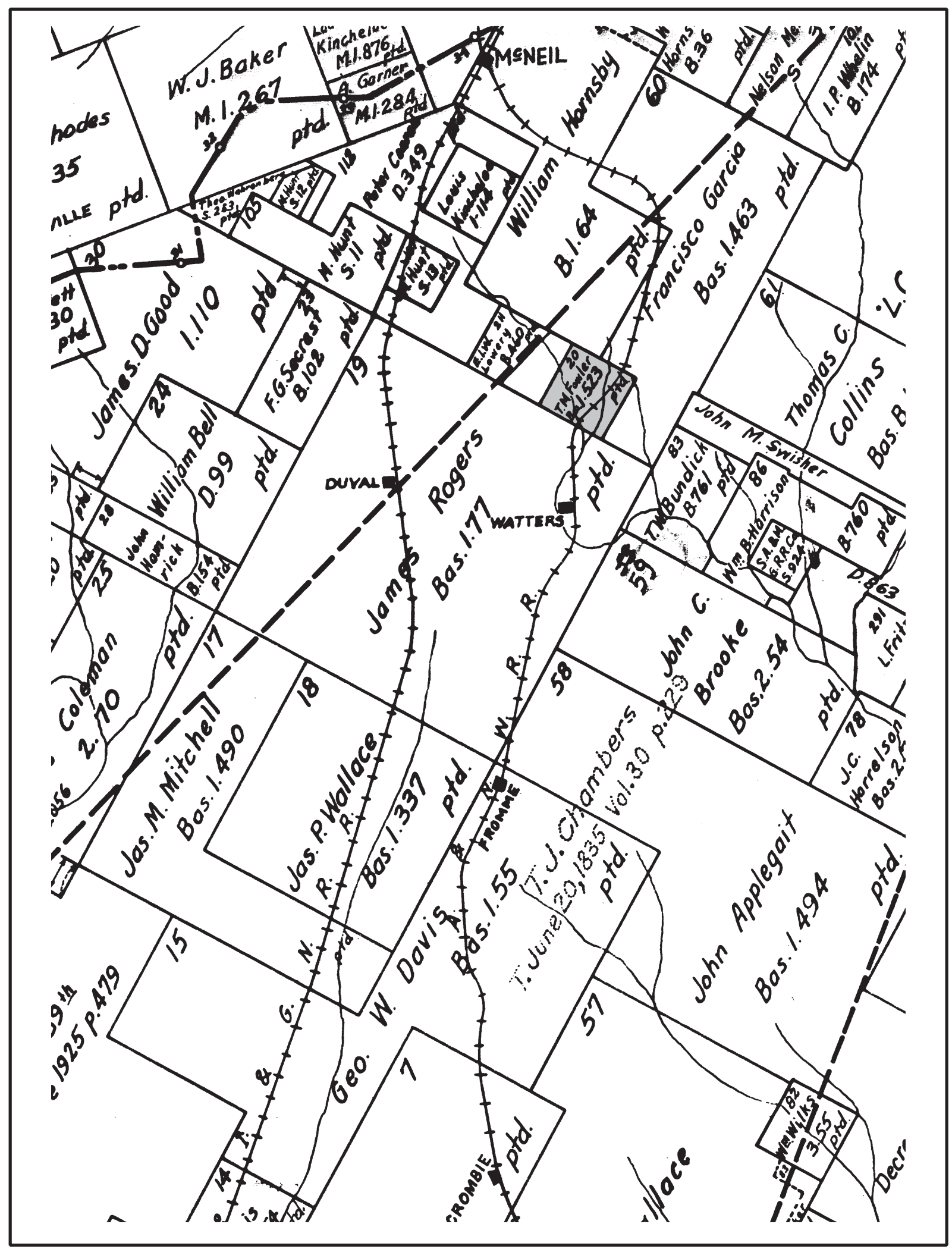

Figure 9. Map of north-central Travis County, 1936. The Fowler Survey, on which Rubin Hancock's farm was located, is shaded. Courtesy of the Texas General Land Office. 
1885. It was a substantial price for the period, and it is likely that the land was in cultivation or otherwise profitable at the time of the purchase. Also in the Applegait Survey and on the Austin and Georgetown Road, the new parcel lay a little north of the original parcel and was about 9 miles northeast of Austin (Travis County Deed Record 55:30-31). This area now contains a large subdivision including Dobie Middle School, north of Rundberg Road, east of Interstate Highway 35. Several street names in the subdivision, including Salem, Applegate, and Fiskville Road, date to the area's earliest rural development.

As Peyton purchased his first farm and Salem expanded his original holdings in the Davis Survey, their brother Orange bought a 100 -acre farm in the James Rogers Survey (see Figure 9). The property lay north of the Davis Survey and in 1877 was valued at $\$ 500$ (Travis County Assessor's Abstract of Land 1877). This probably was the "ungrubbed and unfenced" land mentioned in Emma Hancock Weeks's narrative, where Orange and his sons built the family's two-room log house.

Rubin Hancock was the last of the brothers to buy farmland in the area. Moving still farther north on Upper Georgetown Road, Hancock bought $991 / 5$ acres comprising the north division of the Thomas M. Fowler Survey from Anderson and Martha Peoples on January 1, 1881 (see Figure 9). He paid $\$ 175$ in cash and promised to pay two notes of $\$ 136.69$ each, for a total of $\$ 448.38$ (Travis County Deed Record 48:32324). Peoples and his wife apparently purchased the Fowler Survey with the intention of selling most of it, since they recently had purchased the 177-acre tract from T. L. Wren a few months earlier. The Fowler Survey was located on the "Water of Walnut Creek, about 101/2 miles North East from Austin" (Travis County Deed Record 48:239-240).

After selling Hancock the 991/5 acres, Anderson and Martha Peoples had a little more than 77 acres remaining of the T. M. Fowler labor. The land lay adjacent to an 18-acre tract in the James Rogers Survey that Anderson Peoples had purchased in 1877. The Rogers Survey probably contained their homestead, judging by its value relative to the Fowler land; in 1881 , it was assessed at $\$ 200$ for 18 acres compared with $\$ 200$ for 77 acres in the Fowler Survey (Travis County Assessor's Abstract of
Land 1881). An unrelated 1881 deed record mentions their dwelling near the west line of the Fowler Survey (Travis County Deed Record 49:249-250).

Although Orange and Salem Hancock already owned land in the Rogers and Davis Surveys, by the end of 1881 both brothers purchased farms farther north. Shortly after Rubin purchased his homestead on the Upper Georgetown Road, Orange purchased a 40-acre farm near the newly platted town of Duval. He paid Thomas T. Burns and his wife, Arbanna, a mere $\$ 60 \_\$ 52$ cash in hand with $\$ 8$ promised by September 1, 1881-for the farm tract carved from the northeast corner of the F. G. Secrest Survey (see Figure 9) where it met the northwest corner of the James Rogers Survey (Travis County Deed Record 51:342-343). Slightly west of the I\&GN tracks, Orange Hancock's new parcel lay northwest of the new town and about a mile west of Anderson Peoples's and Rubin Hancock's farms. He retained his 100-acre parcel in the Rogers Survey. About the same time, Salem appears to have sold his land in the Davis Survey and moved farther north. He purchased 107 acres in the James Rogers Survey (Travis County Assessor's Abstract of Land 1881). The farm lay between Orange's new property and Rubin's and Anderson Peoples's lands near the new A\&NW line that ran roughly parallel to Upper Georgetown Road.

There is no evidence that freed slaves intentionally formed a community in the vicinity of what would become Duval and Waters Park. Rather, it appears that the four Hancock brothers and other African Americans purchased land near one another along the main roads that connected them to markets in the early to mid-1870s. At first, the farms spread in a fairly linear progression northward along the main roads from the John Hancock plantation, but by the mid-1870s, when the I\&GN Railroad established Duval Station midway between Round Rock and Austin on its new track, a small community began to take shape.

\section{ESTABLISHMENT OF DUVAL AND WATERS PARK}

About 1876, the I\&GN hired John C. Duval, veteran of the Texas War for Independence, the Mexican War, and the Civil War, to locate and 
survey property that the company had acquired from the State of Texas (Anderson 1967:9). The first mention of construction at Duval appeared in an 1876 Austin newspaper article about the push to complete an extension of the I\&GN Railroad between Austin and the new station of Round Rock. The railroad was predicted to have cars running by September 1876, in time for the "early fall trade." It further mentioned that the first "important" station west of Rockdale, situated 34 miles from Austin on Mustang Creek and directly on the "great cattle trail," was to be called Taylor and that a new station called Duval would be created between Austin and Round Rock (Austin Democratic Statesman, 30 April 1876:3).

By late summer, the Statesman staff expressed skepticism that the new Duval Station would be open for business by August 20 , as projected by the railroad company (Austin Democratic Statesman, 17 August 1876:3). In September, the newspaper staff was proven partially correct when it was treated to a tour of the new stations at Duval and Round Rock, where 2 months earlier "not a house adorned the spot." Reporters saw nearly 50 completed houses and numerous stores at Round Rock, and they predicted that the Williamson County town soon would compete with Austin for "the frontier and inland trade." In contrast, at Duval there was "nothing but stones and stumps and brush and trees and a host of men busy at work on the railroad and about a dozen carpenters putting up a section house." However, lumber was on the ground for a depot, and telegraph had service already been extended to the station. Railroad contractors predicted that it would be open for business within a month (Austin Democratic Statesman, 13 September 1876:3), and by the first of October the right of way on the upper route between Austin and the Duval Station had been secured.

Ira H. Evans, secretary of the I\&GN, placed an advertisement for the sale of town lots at "the New Town of Duval at the old Rogers Mill" in the Austin Democratic Statesman (13 September 1876:3) in late September (Figure 10). Evans announced that, while the station was the present terminus of the road, it was only "nine miles from the city, within 300 yards of a large spring and surrounded by fine agricultural country" (Austin Democratic Statesman, 27 September 1876:2). The auction

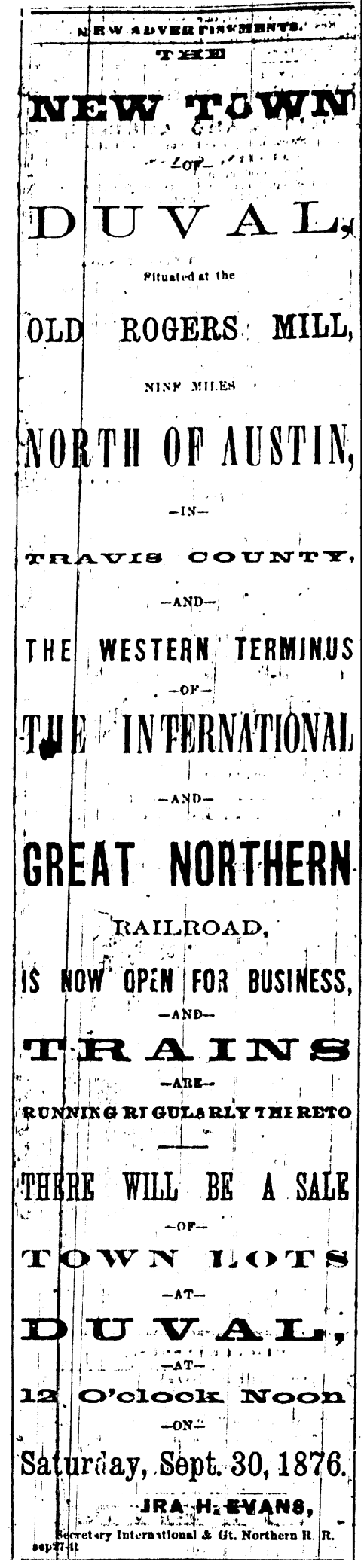

Figure 10. Advertisement for sale of lots at Duval. 
was held on Saturday, September 30, 1876, but in spite of Evans's glowing report, not a single lot sold. Several lots were put on the block, but the few people present declined to bid (Austin Democratic Statesman, 1 October 1876:3). No explanation was given for the lack of sales. Perhaps Duval was overshadowed by the intense promotion and industry at nearby Round Rock, or perhaps some serious shortcomings were found with the property.
Occasionally, Duval appeared in newspaper notices such as the one announcing that the Young Men's Democratic Club would be stopping at "Webberville, Oatmanville, Waters Park, Duval and Merriltown [sic]" to give political speeches or debates (Austin Democratic Statesman, 15 October 1876:2). A 16-lot plat for Duval was filed on December 20, 1880 (Figure 11), but the town never developed as intended, and it fell into obscurity as quickly as it had come into being.

In 1881, when the A\&NW Railroad laid track through Rubin Hancock's farm on its way north, it began promoting a new community at Summers Grove, renamed Waters Park (also known as Watters or Waters), about half a mile south of Hancock's land (Figure 12). Promoted by the railroad company as a recreational destination for Austin residents, Waters Park enjoyed some degree of success as a resort in the years following its establishment in 1882. By the 1890s, Waters Park had eclipsed Duval. The A\&NW Railroad developed picnic grounds and a park on the 5-acre Summers Grove site and advertised free admission for Austin citizens (Clark 1998:45). Like nearly all such railroad endeavors, the park probably was promoted as an attraction for future

Figure 11. Plat of the Town of Duval (Travis County Plat Maps, Vol. 1). 
The Rubin Hancock Farmstead, 1880-1916

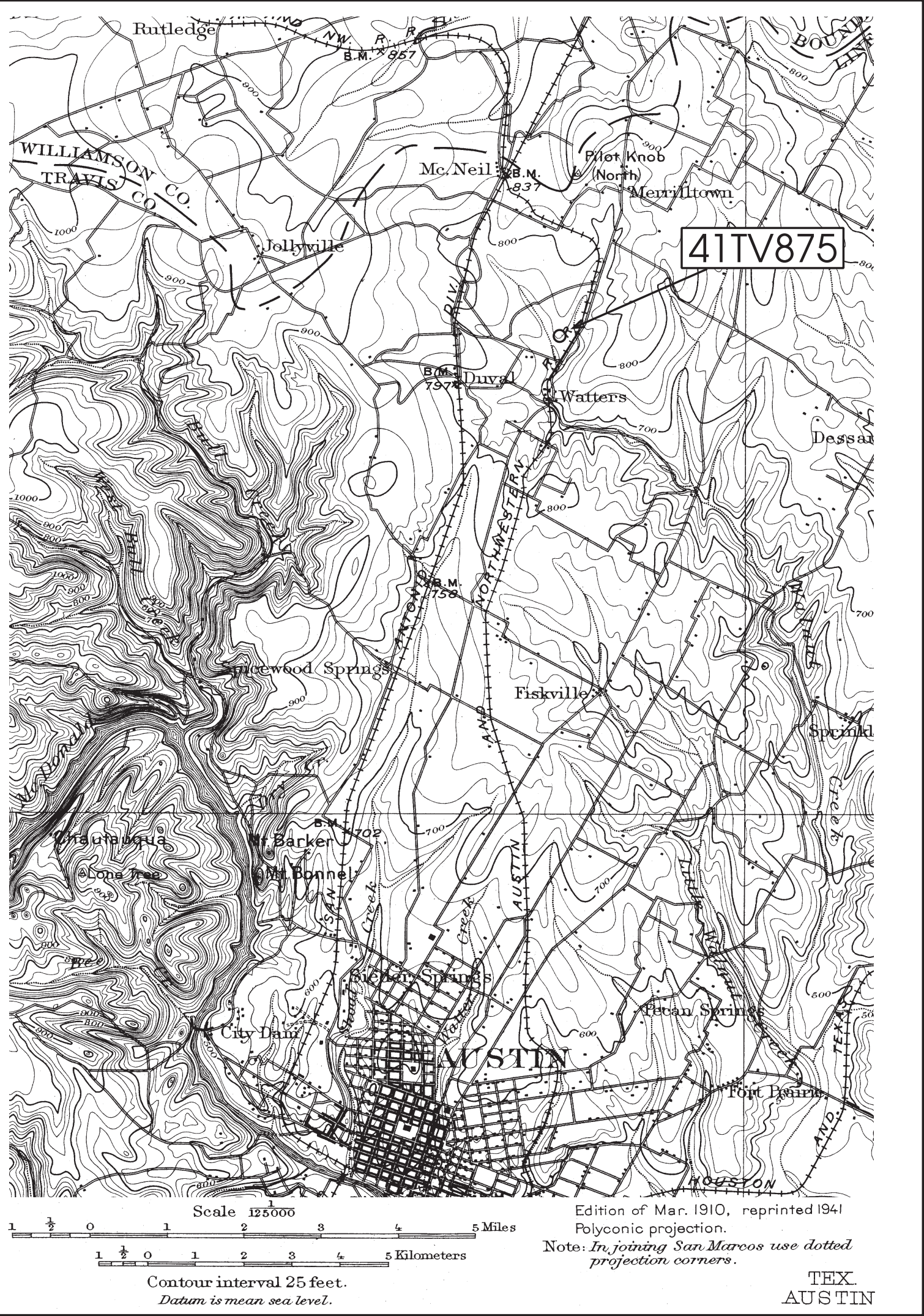

Figure 12. Section of 1910 USGS map of north-central Travis County showing the locations of Duval, Waters Park, and other communities. 
land sales. Waters Park never grew to rival other railroad stations of its era, like nearby Round Rock or Taylor, but its small businesses did a fair tourist trade in the 1890 s and early 1900s. It may have been a sign of things to come when the post office at Waters Park was discontinued in 1905. World War I spelled the demise of Waters Park. Train excursions to the picnic grounds and swimming holes ceased during the war and never were resumed afterward. The community's significance as a recreation spot declined. As a result, the enterprises that previously centered on a tourist economy dwindled in importance.

By the time the railroads were promoting Duval and Waters Park, many African American families destined to become permanent residents in the community, including the four Hancock brothers, were already living on farms in the vicinity. When the 1880 census was taken, Rubin Hancock; his wife, Elizabeth; and their children, Susie, John, Fannie, and Mattie, were already living on their farmstead on Upper Georgetown Road, as were their kinsmen, Anderson and Martha Peoples. The oldest daughter, Melvina, appears to have left home by the time her parents bought their farm. Other families who lived in the area in the 1880s included preacher James Daniels and his family, who lived immediately north of Rubin Hancock; Daniels's son, Simon Daniels Sr., his wife, Sophie Hancock Daniels, and their children, including Lillian Daniels Robinson; Will Robinson and his wife, Sarah Fucles, a relative of Anderson and Martha Peoples (Fucles); and J. S. Hansborough and his family (U.S. Bureau of the Census 1880a). From oral histories conducted with descendants Lillian (Hancock Daniels) Robinson, Alma Mae (Hancock Hansborough) Shelby, and Mabel (Hancock Walker) Newton, nearly all of the African American families who lived on neighboring farms between Duval and Waters Park were related to one another by blood, marriage, or previous condition of servitude. Thus, while these families lived rural lifestyles, they were not isolated from other African American contacts.

\section{THE AFRICAN AMERICAN COMMUNITY IN THE LATE NINETEENTH CENTURY}

Life for the Rubin Hancocks and the other
African American farm owners in the DuvalWaters Park area probably was typical of other small farm families in central Texas during the latter part of the nineteenth century. As soon as they acquired their farms, they must have built a small frame house of two or three rooms, dug a well, erected some outbuildings, and fenced enclosures for horses and livestock. According to descendants of these African American farmers, most people had some acreage in cotton, corn, and oats, and they would have started vegetable gardens for their personal use. According to his granddaughters, Rubin Hancock raised corn, oats, and a little cotton, and he maintained two gardens. Descendants recall that the Hancocks had a good orchard where they grew peaches and plums (Newton 1999; Shelby 1987). They relied on their livestock and dairy cows for cash and made a relatively good living (Newton 1999). Although the 1880 census noted that Elizabeth and virtually all the neighboring women were "keeping house," without doubt, they contributed to the farm production and probably were in charge of making butter and selling eggs for extra money. Rubin and Elizabeth's son worked on the farm by the age of 13, as did other young men and boys. Daughters helped with chores as well.

Although Hancock was renting his farm when the 1880 agricultural census was taken, he purchased the property within the year. His land, fences, and buildings were valued at $\$ 600$, and the estimated value of all farm production totaled \$200. Hancock reported that he had 35 acres of tilled, improved land, with $\$ 35$ worth of farm implements and machinery and $\$ 125$ in livestock, including 3 horses, 2 working oxen, 5 milch cows, 4 other cattle, 3 calves, 5 swine, and 20 barnyard fowl. His milch cows produced 300 pounds of butter made on the farm, and his chickens produced 150 dozen eggs (U.S. Bureau of the Census 1880b).

Of the 10 farms grouped together with Rubin's in the 1880 agricultural census, his was the least valuable, but it also was the only rented farm among them. The group was racially mixed with seven Whites and three African Americans. All of the White-owned farms carried greater value than any of the African American farms, with White-owned farms averaging a little more than $\$ 1,100$ compared with African American-owned farms 
at an average of $\$ 700$ per farm. Rubin had planted 25 of his 35 cultivated acres in Indian corn, which produced 50 bushels of corn in 1879 . He also had 3 acres in oats, which yielded a 25bushel crop. The census also shows that Hancock had 15 acres in cotton-more than any other farmer in his group-yielding 2 bales, and he was the only one to grow sweet potatoes, devoting 4 acres to produce 7 bushels of potatoes. In 1879 , he cut 8 cords of wood estimated to be worth about $\$ 25$. From the number of acres devoted to different products, it appears that Hancock rotated his crops or had more land in cultivation than the enumerator counted. With the exceptions of cotton and sweet potatoes, Hancock's crops and livestock seem to have been similar to other nearby farmers. Like all the farmers in his area, he devoted most of his land to corn with some acreage in cotton (U.S. Bureau of the Census 1880b).

One way in which Hancock and his neighbors differed from other African American farmers-and indeed many White farmers - in central Texas during the late nineteenth century was that they owned their own farms. Most rural African Americans in Travis County worked as farm laborers, tenant farmers, or sharecroppers from the late nineteenth century through the first half of the twentieth century. In this regard, the former slaves of the DuvalWaters Park area enjoyed rare status as property owners.

The 1880s and 1890s appear to have been fairly good years of modest gains for Rubin Hancock and his neighbors. Tax records indicate that Hancock's original 99-acre farm was worth $\$ 300$ in 1881, and even after he sold 12 acres to Dorcas Gregg and granted several acres of right of way to the A\&NW Railroad, his property's value had increased to $\$ 340$ by 1885 . In addition, his livestock increased from 10 head of cattle worth $\$ 60$ in 1881 , to 20 cattle worth $\$ 200$ in 1885 (Texas. Ad valorem tax records 1881-1885). By 1898, Rubin Hancock's 83-acre farm was worth $\$ 1,000$ (approximately $\$ 11.76$ per acre), a three-fold increase from 1885 . His livestock, however, decreased in value from $\$ 10$ a head in 1885 , to only $\$ 5$ apiece for 6 head of cattle in 1898. By the turn of the century, Hancock appears to have had an established agricultural operation that compared well with those of his kinsmen who were farming in the same area. For instance, his brother Orange's farms were valued at $\$ 700$ for 100 acres ( $\$ 7$ per acre) in the James Rogers Survey and $\$ 80$ for his 40 -acre tract ( $\$ 2$ per acre) in the Secrest Survey. Peyton's 107.5-acre farm in the Applegait Survey to the southeast was more valuable than most of the farms in the Fowler, Secrest, and Rogers Surveys. It was assessed at $\$ 1,075$ in 1885 , or $\$ 10$ per acre (Texas. Ad valorem tax records 1885-1900).

While much can be learned about life in the Duval-Waters Park area during the latter part of the nineteenth century based on documentary evidence, the slave narrative of Emma Weeks, Orange Hancock's daughter, provides a rare first-person account. Emma reported that one of her primary tasks as an adolescent on the family farm between 1870 and 1876 was to milk the cows. She milked as many as eight cows twice a day, which supplied enough milk to make butter for the family and to sell. Her mother, Rhody, went by buggy to individual families where she sold about 10 pounds of butter per week for "two bits" (about twenty-five cents) per pound (Weeks 1937:369). According to Emma, the family used both barter and cash to maintain their livelihood in the 1870s. While Orange and his brother received stock as payment for rounding up cattle, Rhody received cash for butter and probably eggs (Weeks 1937:369). The family also was able to support a hired man, although it is not known whether he was paid in wages or board. Orange Hancock hired a man thought to have been brought from Africa named Joe Slick to help on the family farm. Joe Slick boarded with the family, and Hancock trusted him to plow and plant crops in his absence (Weeks 1937:370).

Emma reported that after slavery she attended school for a single winter where she learned to read a little but not write. An African American woman named Bettie Hill taught classes in a small log schoolhouse in the country, although its location remains unknown. Emma stated that she didn't have a chance to go to school much. Most likely, she and her siblings were needed on their family farm. Social life consisted of occasional dances and attending church. Joe Slick played the banjo and taught the young people to dance (Weeks 1937:268). Emma enjoyed going to a Baptist Church with her brothers and sisters on alternate Sundays. The church's location is not known, but it may have been an early incarnation of St. Stephens 
Missionary Baptist Church.

The St. Stephens Baptist Church probably was the most significant religious and social institution for the African American community in the Duval-Waters Park area during the late nineteenth century. Although St. Stephens Church was not officially organized until 1887 , the congregation's history recounts that area residents met in a one-room frame building about $11 / 2$ miles west of the later church site (currently at 3505 Adelphi Road, which is old Duval Road) by the early 1870 s. The earlier building, which lay in the vicinity of Duval Station, served the surrounding African American community as both church and school (Fontaine and Burd 1983:48; St. Stephens Missionary Baptist Church 1998). Services probably were held on an irregular or semiweekly basis, according to the schedules of itinerant preachers who traveled from church to church in such rural areas.

Completion of the A\&NW Railroad in the early 1880s drew greater numbers of African Americans to the Waters Park area, warranting the organization of a more permanent church. In 1887, the Reverend Jacob Fontaine, minister of Austin's First Baptist Church, organized the St. Stephens Baptist Church at Waters Park. A former slave of Edward Fontaine who was rector of Austin's St. David's Episcopal Church, Jacob Fontaine organized many African American churches, including Sweet Home (Clarksville 1877) and New Hope (Wheatville 1887), in the expanding city and rural communities after emancipation (Fontaine and Burd 1983:42-45).

The Reverend Stephen Smith served the church as its first pastor, followed by James Daniels, a lifelong leader in the congregation. Anderson Peoples, James Daniels, and George Ross were its deacons. Other early members included Alonzo Johnson, Frank Robinson, Albert White, Jack Black, Burl Adams, and Alonzo King. Waters Park residents Arch Adams, Orange Hancock, Callie Harris, P. D. Organs, Will Robinson, George Manor, Ben Sheperd, and Deacon Simon Daniels Sr. all made significant contributions to the establishment and continuation of the church (Fontaine and Burd 1983:48; St. Stephens Missionary Baptist Church 1998). Absent from the roster are Rubin Hancock and his wife, who were members of St. Paul Baptist Church, which was located several miles south of Waters Park on the
A\&NW Railroad near present-day Ohlen Road (Newton 1999).

In 1888, shortly after St. Stephens Church was organized, Anderson Peoples and his wife donated 1 acre of land in the Fowler Survey to the church (Fontaine 1999:48). The acre, which contained a building, lay at the northwest corner of the Peoples' property where it joined Rubin Hancock's homestead (Travis County Deed Record 82:165-167). Records are unclear as to the construction date for the church building. According to written histories, the St. Stephens congregation built a church on the Peoples' donated land in 1913, but there is no mention of an earlier building. It is possible that the congregation met in the building noted in the Peoples' 1888 deed until a new building was constructed on the site in 1913. To date, written records, church histories, and interviews with long-time residents have revealed no further information about where the congregation met from 1887 to 1913.

When Anderson and Martha Peoples donated their property, they included a stipulation in the deed requiring that "school is allowed to be taught in the building now situated on said acre" (Travis County Deed Record 82:165-167). It is the first known record of a school for African American children in the Waters Park area, and the building apparently predated the church organization. The school must have played an important role in the lives of these emancipated slaves. Census records reveal that few of the adult members or older children of the extended Hancock family learned to read and/or write. Neither Rubin nor Elizabeth Hancock could sign their names; instead they made "their mark"-an X-to indicate their signatures on legal documents. Among their generation of freedmen within the extended family, only Martha Peoples is known to have been able to write her own name. It may have been her interest in education that prompted the deed stipulation requiring that a school be allowed to operate in the building she and her husband donated to the church. Because Rubin Hancock and his immediate family were members of St. Paul's Baptist Church, which also had a school, it is possible that his children attended school there. Unlike their parents, Rubin and Elizabeth's children all learned to read and write, and Susie is thought to have been a teacher for a short time (Collins 1999b). 
In 1913, the St. Stephens congregation built a new church on the Peoples' 1-acre site. That is also the first year in which the St. Stephens School appears in Travis County school records. Until that time, school may have been taught on a voluntary or impermanent basis. With the construction of a new sanctuary, however, the school became institutionalized and was recognized as a Travis County rural school. It appears on a 1915 school district overlay map at the southwest corner of Rubin Hancock's farm where Duval Road makes a sharp turn to the south (Figure 13). Several Hancock family members were listed in the 1913-1924 school rosters, including Rubin and Elizabeth's granddaughter Alma Mae Hansborough (Shelby 1987), Salem's grandchildren Ruth and L. G., and Orange's son Tommie and grandson Dee (Shelby 1987). Also known as Watters Park Colored School, the school continued to operate from the church through the mid-1920s and served African American students from as far away as Pflugerville (Coleman 1999; Shelby 1987).

\section{THE AFRICAN AMERICAN COMMUNITY IN THE TWENTIETH CENTURY}

Although the I\&GN and A\&NW Railroads passing through the project area afforded many new business opportunities-particularly at Waters Park-African Americans appear not to have taken active commercial roles in the new community, which was dominated by White businesses and farmers. From their earliest occupation of the land through the 1930s, African Americans almost exclusively worked as farmers or farm laborers in this area, although a few worked as laborers for the railroads. A significant number, like Rubin and Orange Hancock, Anderson Peoples, P. D. Organ, John Hansborough, and James Daniels, owned their own farms and enjoyed a certain autonomy and status unknown to the field laborers, tenant farmers, and sharecroppers who comprised the majority of rural African Americans in Travis County from the 1880 s to the 1930 s.

In general, the original African American farms in the Duval-Waters Park area remained in the hands of first- or second-generation owners in the period ranging from about 1888 through the 1910s. For these farmers, many of whom were born into slavery, property ownership, protected family relationships, and status as leaders within their church and school communities translated to a relatively high level of success. After the turn of the century, however, fewer African American families purchased new farms in the area. While many of the old-timers still owned homesteads purchased in the 1870s and 1880s, newcomers and even the children of original settlers tended to be renters rather than owners. In addition, greater numbers of White farmers, including German and Swedish families, moved into the area and bought up farm land as Travis County's population grew in the new century. At the same time, hundreds of Mexican citizens flooded into Travis County beginning about 1910, as the Mexican Revolution forced thousands of people to flee their homeland. While many Mexican families lived in the McNeil area (see Figure 12) where they found work at the Austin White Lime Company, others moved to Waters Park. African Americans may have been faced with inflated land prices caused by greater demand and fewer jobs due to competition from recent immigrants. In any case, the number of African American families in the area encompassing Waters Park and Duval declined from the 1880 census to the 1910 and 1920 returns (U.S. Bureau of the Census 1880a, 1910, 1920).

The 1880 census for Travis County, Precinct 4 , enumerated 215 families/households, of which 30 percent $(\mathrm{n}=65)$ were described as Black or Mulatto, 69 percent $(\mathrm{n}=149)$ were described as White, and 1 percent $(n=2)$ were described as Hispanic. By 1920, the enumeration districts were divided somewhat differently, but the project area would have been encompassed by the Anderson Mill, Merrilltown, Summit, and McNeil subgroups. Waters Park and Duval were not specifically named, but they would have been located in the Merrilltown and Summit groups. Taken together, those two areas were populated by 134 families, with 11 percent $(\mathrm{n}=$ 15) being Hispanic, 68 percent $(n=91)$ being White, and only 21 percent $(n=28)$ being Black.

By 1915, Rubin Hancock was the only one of his brothers still living in the Duval-Waters Park area. Orange died in 1908 and Peyton died by 1915 (Texas. Ad valorem tax records 1915). Salem disappeared from the tax and census records (Texas. Ad valorem tax records 1915; 


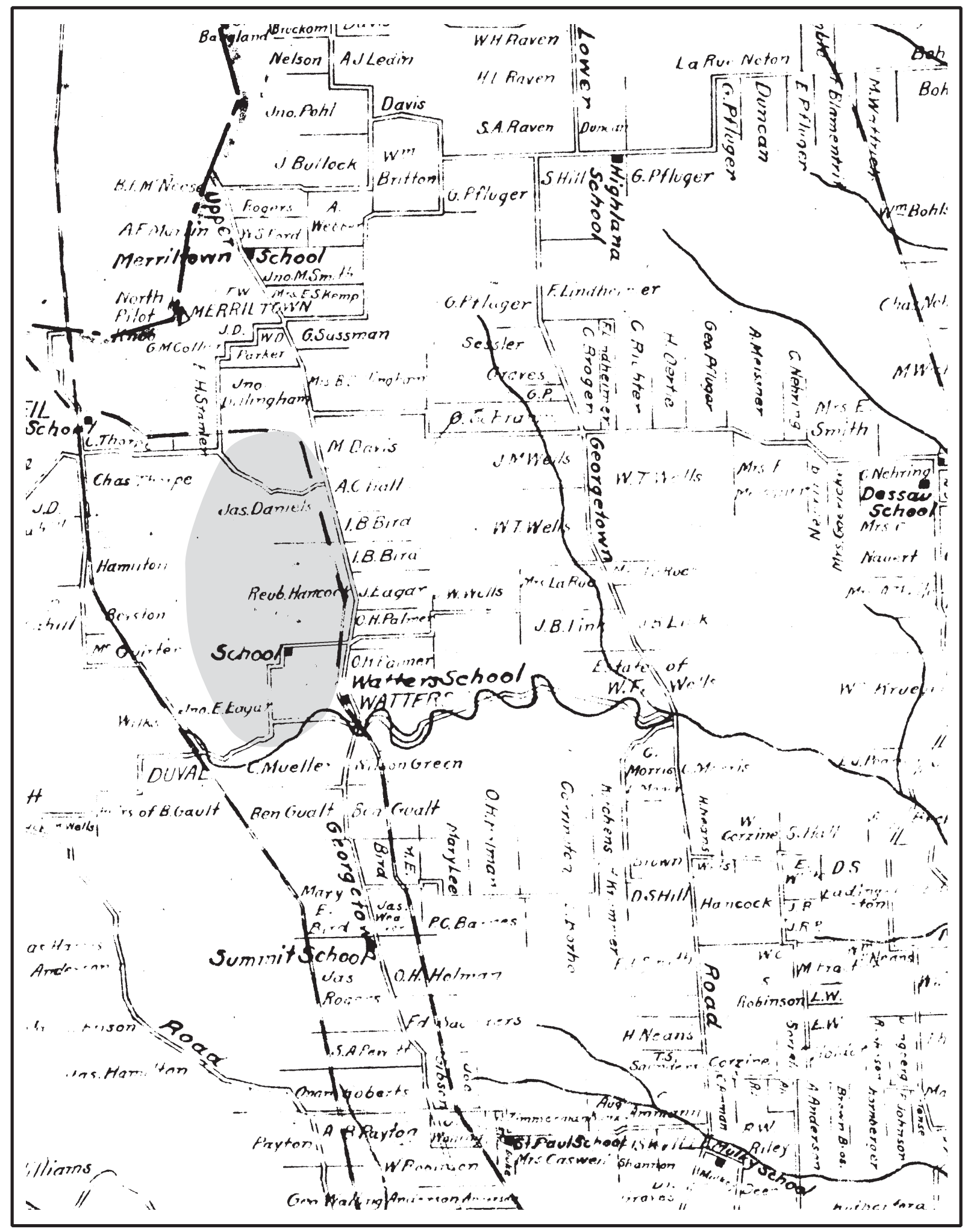

Figure 13. Map of roads in north-central Travis County, 1898-1902, retraced in 1915, showing schools and land owners with the project area shaded. Courtesy of the Austin History Center. 
U.S. Bureau of the Census 1910, 1920), and Anderson Peoples moved to south Austin (Morrison and Formey 1909). Rubin Hancock died the following year, leaving his land to his three daughters by his wife Elizabeth.

From oral histories and rural school records, it appears that of all Rubin's children, only Mattie Hancock Hansborough lived at Waters Park her entire life. She and her husband, John, established a farm immediately north of her father in the Francisco Garcia Survey (see Figure 9), and they retained the adjacent 10 acre tract of Rubin Hancock's farm as well. Shortly after Rubin's death, however, his daughter Susie Dickerson and her husband, William, moved back to the farm and either built a house across from Mattie Hancock Hansborough or occupied their father's house.

By 1920, the demographic composition of the Waters Park area had changed significantly from that at the turn of the century. Both Waters Park and Duval had declined in importance as rural hubs after World War I, and neither community is identified in the 1920 census. The advent of the automobile and better roads had a tremendous impact on rural communities. They gave farmers greater direct access to outside markets, reducing the importance of the rural railroad stations such as those at Duval and Waters Park. Automobiles also gave rural residents the opportunity to travel greater distances for shopping and recreation, and they began to go to market in Round Rock, Pflugerville, and Austin, where businesses offered better variety, services, and prices than they could find in their country stores.

Although it was a period of general prosperity for the nation as a whole, farm prices declined after World War I when military demands and inflated cost of agricultural products ceased. Farmers had a hard time making ends meet, and many young people began to leave the country for new jobs in the city. Others left to pursue educational goals. In Waters Park and most other rural communities in Travis County, there were no high schools for African American students. Students who wanted to go beyond grade school boarded with families in Austin so that they could attend L. C. Anderson High School. Many never returned home to the farm after they graduated (Coleman 1999; Newton 1999).

After the turn of the century, distinctly new separate community enclaves existed within the small geographic area of north-central Travis County roughly lying between the old Upper and Lower Georgetown Roads. The enumeration district that contained this area in 1920 was comprised of the Merrilltown, McNeil, Anderson Mill, and Summit subdistricts, all within Justice of the Peace Precinct No. 4. Neither Duval nor Waters Park was named a subdistrict in 1920 . Each subdistrict had defining demographic characteristics, but the African American community around Waters Park was divided between the Merrilltown area to the north and the Summit area to the south. The Merrilltown subdistrict stopped just north of Rubin and Elizabeth Hancock's old farmstead, which was included in the Summit subdistrict.

The Merrilltown subdistrict included property along both the Merrilltown and Fiskville Roads, as well as surrounding territory. The subdistrict consisted almost entirely of farm tracts whose heads of household were listed as farmers; the older sons living within the households were listed as farm laborers. In this subdistrict, women universally were shown as having no occupation-not even "keeping house"-regardless of their status as wives or heads of their own households. Both African American and white families lived in the subdistrict, including two of the early settlers and organizers of the St. Stephens Missionary Baptist Church, Simon Daniels Sr. and his wife, Laura. Daniels owned his farm free and clear also were in the subdistrict on Merrilltown Road. Daniels's son, Simon Daniels Jr.; his wife, Sophie Hancock Daniels; and their daughters, Sophie, Sally Mae, Stella, and Silesta (Celesta), also lived in the subdistrict on Merrilltown Road. Other African Americans in the subdistrict included the families of Sarah King, Monroe Mercer, and Will Robinson (U.S. Bureau of the Census 1920).

In contrast, the McNeil subdistrict was dominated by Mexican-born residents, most of whom either worked at the lime kiln-the community's largest employer-or for the I\&GN Railroad (U.S. Bureau of the Census 1920). According to the 1901 publication, Austin Texas Illustrated, McNeil was founded as a company town that served the interests of the Austin White Lime Company, one of the largest lime works in Texas at that time (Newning 1901). The community's only store at the turn 
of the century was the company commissary, and nearly everyone within a few miles of the plant was employed by Austin White Lime. Some worked directly for the company in the lime works or cooper shop where they made barrels to transport the lime, while others cut and hauled the wood needed for production (Newning 1901:39). Twenty years later, when the census was reported, little had changed. Nearly everyone who was not a farmer worked for the lime company in one way or another. Of the 244 people in the McNeil subdistrict, 166, or nearly 70 percent, had Spanish surnames and nearly all of those were Mexican born. Immigration dates ranged from 1896 to 1917, but the majority came to the U.S. in 1910 . Nearly all lived with their wives, but few had children listed in the households, possibly because they intended to return to their families in Mexico. White Americans and the few European immigrants who lived in the subdistrict generally owned or worked on farms, although there was one mercantile operation and one railroad foreman among this group. No African Americans were enumerated in the McNeil subdistrict.

Unlike the McNeil subdistrict with its large Mexican and Mexican-American population and the Merrilltown area where both African American and White residents lived and worked, the Anderson Mill area was populated entirely by non-Hispanic Whites. The subdistrict was relatively small, with a total of 56 residents, who all lived on farms.

The Summit subdistrict contained most of the area associated with the Duval-Waters Park vicinity. It was the largest of the four subdistricts in the enumeration district, with 997 residents. Consisting largely of farmers and railroad laborers, the area had both African American and White residents with some Mexican-born residents, although non-Hispanic Whites dominated the area. In addition to farmers, the Summit subdistrict had the greatest variety of occupations, with a barber, grocery store manager, minister, wood yard laborer, several stock farmers, and 18 railroad workers divided between the H\&TC (formerly the A\&NW) and I\&GN Railroads. With the exception of the I\&GN section foreman who was German, all of the railroad workers were Mexican born. The only woman in the subdistrict who was identified as being employed was an African American who worked as a servant in a private home (U.S. Bureau of the Census 1920).

Descendants of Rubin, Orange, and Salem Hancock lived in the Summit subdistrict in 1920. Among them were Mattie Hancock Hansborough, her husband, John, and their only child, Alma Mae. Mattie's cousin, Salem Hancock's son Richard, lived on the adjacent farm with his wife, Fannie, and their children, Ruth and L. G. Other nearby households associated with St. Stephens Church included the Peter Organ, J. S. Hansborough, and John Louis families. All of the African American household heads in this area were listed as farmers or farm laborers, with their farms being interspersed among white farms (U.S. Bureau of the Census 1920).

Although individual census information is not available for the $1930 \mathrm{~s}$, tax records for that decade indicate that property values declined tremendously from 1900 and 1920. Many longestablished White and African American families in the area disappeared from the tax rolls. By that time, nearly all of the original African American settlers had died, while others sold or abandoned their farms and moved off the land or otherwise gave up property ownership.

However, several families who owned land in the Thomas M. Fowler Survey in 1920 owned the same parcels 20 years later. In 1940, Rubin Hancock's daughter, Susie Dickerson, lived in the Fowler Survey, next to Archie Adams, a lifelong member of St. Stephens Church. Her husband, William, died in 1938, leaving Susie as sole owner of 28 acres valued at $\$ 560$ and 45 acres valued at $\$ 90$. The 45 -acre tract was listed as Dickerson's homestead. Although her sister Mattie also died by 1940, Mattie's husband, John Hansborough, still owned his farm in the F. Garcia Survey (a 20 -acre tract valued at $\$ 400$ and a 36.5 -acre tract valued at $\$ 80$ ), as well as the 10-acre tract in the Fowler Survey (valued at $\$ 20$ ), left to Mattie by her father. The combined 10-acre Fowler and 36.5-acre F. Garcia parcels were Hansborough's designated homestead tracts. In addition to Rubin Hancock's heirs, Archie Adams and his wife still owned a 36-acre parcel (valued at \$500) out of the Fowler Survey that appears to have been part of Anderson Peoples's early farm (Texas. Ad valorem tax records 1940). 
The Dickerson and Hansborough tracts account for the disposition of Rubin Hancock's 83- acre farmstead that he held at his death. Since both Dickerson and Hansborough listed the land as their homesteads, it is assumed that they occupied the land. Susie Dickerson signed an affidavit filed in Travis County (Travis County Deed Record 706:63-64) stating that she and her husband moved to the site after her father died in 1916. However, varying addresses for the Dickersons through the 1930s indicate that they may not have lived on the farm continuously throughout the period. By 1940, the only Hancocks living in the vicinity of the project area were Fannie, Richard Hancock's wife, and John Hancock, a descendant of Salem or Orange, who owned a 98-acre tract of land in the James Rogers survey near the old Rubin Hancock farm. John Hancock's land was valued at $\$ 780$, a little less than $\$ 8$ per acre. Fannie Hancock lived on a 1-acre tract of land adjacent to the Fowler Survey worth $\$ 50$. Richard Hancock no longer appeared in the tax records and may have been dead by that time (Texas. Ad valorem tax records 1940). The African American-owned parcels were generally smaller and appear to have been less valuable than nearby white-owned farms in 1940. For instance, E. H. Gault owned 200 acres in the Rogers Survey valued at $\$ 1,800$, and a second tract of 235 acres in the same survey was assessed at $\$ 1,000$ (Texas. Ad valorem tax records 1940).

During World War II, both John Hansborough and Susie Dickerson sold the farms that had been in the Rubin Hancock family since 1881 -more than half a century. As the older generations of African American farm owners passed from the area in midcentury, the community founded by former slaves continued to dissipate until there were only a few elderly people left in the area. In the early $1970 \mathrm{~s}$, the community's only institution, St. Stephens Missionary Baptist Church, burned. Few of the remaining 38 members still lived in the area, and most felt that a new church should be built in East Austin where most of the congregation had moved. Mrs. Lillian Robinson, granddaughter of founding member James Daniels, made a strong case for keeping the church in its historic setting, and a new church was built on the original site donated by Anderson Peoples. Begun in 1973 and completed in 1978, the church continued to serve its scattered congregation for another 20 years. In 1988, Mrs. Robinson documented the church's history to place a Texas Historical Marker on its grounds (Texas Historical Commission 1988).

After the church was rebuilt, new pastors attracted many new members and the congregation rebounded dramatically. Indeed, the membership had grown so large by 1998 that a new complex was built about half a mile southwest of the 1978 church. Today, St. Stephens Missionary Baptist Church claims more than 800 active members from Travis, Williamson, Hays, and Caldwell Counties. Few are drawn from the immediate neighborhood, which has changed significantly from open fields and country roads to modern housing developments with new schools and shopping areas in the past quarter century (McQueen 1999).

Some of the old names have been attached to the new subdivisions and apartment complexes that replaced the farms that once spread along Duval Road, but almost nothing of the original Waters Park community remains. The 1978 St. Stephens Church still stands on its original site (formerly Duval Road and now Adelphi Road), but it is leased to the congregation of St. John the Forerunner Orthodox Church. The building is one of the area's few surviving cultural resources associated with the original African American settlers of Duval-Waters Park. Though a Texas Historical Marker was placed on the site in 1988 , it was relocated to the grounds of the new church in 1998. Still, the new congregation embraces its historic beginnings which were recounted in the church dedication ceremony in 1998.

Today, countless descendants of community pioneers, including Rubin Hancock, Orange Hancock, Salem Hancock, James Daniels, Archie Adams, P. D. Organ, J. S. Hansborough, and Will Robinson, still live in Travis County, primarily in Austin. They and their families contribute to all aspects of their now largely urban society, as their grandparents and great-grandparents once contributed to the rural community at Duval and Waters Park. 


\section{CULTURAL FEATURES}

\section{4}

\section{ANALYSIS METHODS}

Upon commencement of this project, all records, documentation, and artifacts were transferred from TxDOT to the offices of Prewitt and Associates. The first task was to organize and assess the records and become familiar with their contents. Within the collection, many documents were represented in duplicate. These were sorted into one complete set of records that were either originals, or the most original copies. All duplicates were retained as a separate set. The most original set of records was organized by document type, such as maps, field records, photographic materials, notes on archival research, correspondence, and the like. These materials were read and reviewed to gain an understanding of the Rubin Hancock site and the work undertaken there. The full set of records was photocopied onto archival paper in preparation for curation. Photographic materials were labeled and packaged for curation according to the standards required by the Texas Archeological Research Laboratory.

These records, in combination with the artifacts, were used to generate all data, tables, and maps presented in this report. This report is intended to be an accurate description of the work and the site as documented. Records were cross-checked with each other to ensure consistency of data. John W. Clark Jr. and other individuals with first-hand knowledge of the excavations were consulted to answer questions or solve discrepancies arising from the site records. Additional archival and oral informant research was performed, and additional secondary materials were used in the analysis of the raw data. The use of information supplementary to that resulting from the original work was intended to enhance the final product and not as a substitution for previous efforts.

\section{FEATURE DESCRIPTIONS}

A variety of surface and subsurface historic features were recorded at the Rubin Hancock farmstead. In this analysis, they have been interpreted as two wells (one hand dug, one drilled), the chimney hearth and rubble associated with the house foundation (indicated by rock alignments and artifact distributions), five fences or fence lines, an animal pen, two trash dump areas, the yard area, the garden area, a dog burial, two possible outbuilding foundations, and a pit feature. Each feature is described in detail below.

\section{Hand-dug Well}

The hand-dug well was one of the first features recorded at the site and one of the most prominent components of the cultural landscape that was observed on the surface (Figure 14). It was located on the eastern side of the site in what probably was the main side yard area southeast of the house. The mouth of the well was exposed at ground surface and was roughly circular with a maximum opening diameter of ca. $4.5 \mathrm{ft}$. The well had a straight shaft lined with natural limestone blocks in its upper ca. $2.5 \mathrm{ft}$. A rough concrete mortar was used to lay the limestone. A few limestone blocks were built up above the ground surface, suggesting that originally the limestone lining was of a greater height. It is unknown if any other superstructure was ever associated. Immediately below the limestone lining, timbers were 
The Rubin Hancock Farmstead, 1880-1916

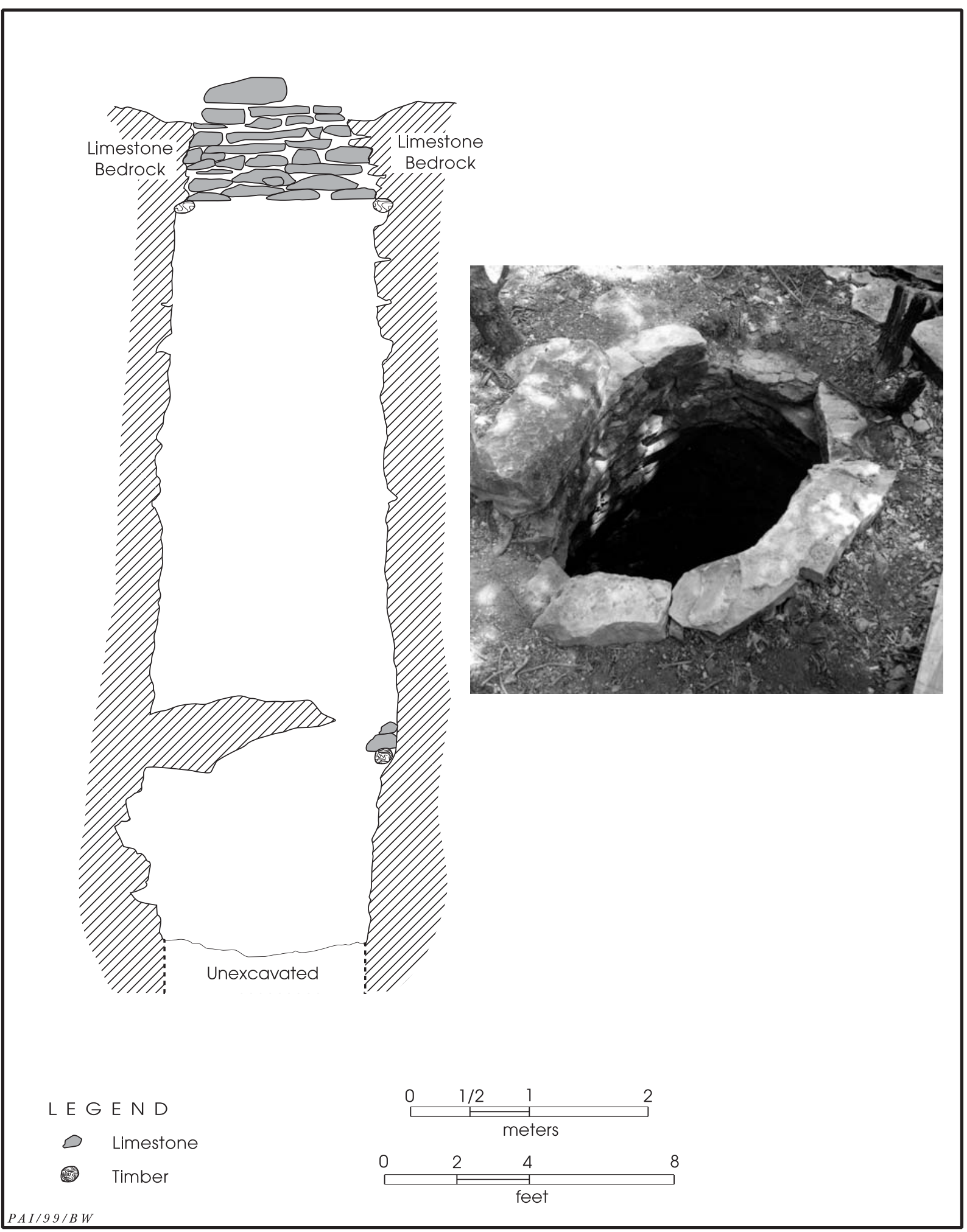

Figure 14. Cross section of hand-dug well and photograph of well opening. 
used for shoring. There is evidence for the use of timber shoring deeper in the shaft, with one timber being in situ ca. $17.5 \mathrm{ft}$ below the surface. The well was dug into the natural limestone bedrock to an unknown total depth. The open well shaft had been used for refuse disposal during the twentieth century. A variety of modern jars, cans, wire, and similar materials were collected from the surface around the mouth of the well. Modern refuse was removed from the well to a depth of ca. $23 \mathrm{ft}$, below which the deposits remained unexcavated. It was hypothesized that the water table was present at ca. $34 \mathrm{ft}$ below the ground surface.

\section{Drilled Well}

The second well at 41TV875 was a drilled well. It probably relates to use of the site after Rubin Hancock's occupation, as his 1916 will specifically mentions a single well at his homestead and the hand-dug well clearly predates the drilled one. According to map measurements, this feature was located approximately $30 \mathrm{ft}$ west of the hand-dug well. It also was in the main side yard area of the house. It consisted of a galvanized metal pipe extending above the ground surface. No artifacts or excavations were associated with the drilled well. No evidence of a superstructure was associated, but a windmill (at least) would have been necessary for pumping water.

\section{Chimney Hearth and House Foundation}

The most important subsurface historic features uncovered were the chimney hearth and house foundation. Although these are functionally different features, they are discussed together here because they serve to define the area of the house itself, which is a crucial aspect of the farmstead. The various components of the chimney hearth and house foundation were exposed in the following units: E588+00/N140, E588+00/N150, E588+00/N155, E588+05/N130, E588+05/N135, E588+05/N145, E588+05/N150, E588+05/N155, E588+10/N155, E588+10/N160, E588+15/N155, E588+15/N160, E588+20/N155, E588+20/N160, E588+25/N160, E588+30/N155, and E588+35/N140 (Figure 15).

The house outline was defined by discontinuous sections of natural limestone block alignments. These alignments were interpreted as the foundation for a frame structure. The foundation was defined best along its western and northern sides. It was less defined along the eastern side, and the southern side of the house was not represented by any feature or stone alignment.

The western side of the house foundation consisted of four sections of roughly linear north-south-oriented limestone rocks. The southernmost section was located in units E588+05/N130 and E588+05/N135 and consisted of about four stones, west of which was a slight dip downslope (Figure 16a). The next section to the north was located in unit E588+00/N140. It was made up of three larger stones and a cluster of smaller stones (Figure 16b). Farther to the north was a more substantial section of the western perimeter. It was located in units E588+05/N145, E588+05/ $\mathrm{N} 150$, and E588+00/N150. There were about seven larger stones loosely clustered with several smaller ones (Figure 16c). The portion of the feature that represented the northwestern corner of the house foundation was located in unit E588+00/N155. It was a small group of ca. four stones. A fragment of a cast iron stove burner was associated with this cluster (Figure 16d).

The northern side of the house foundation was by far the most well defined section. It was composed of two portions: an east-west-oriented alignment of natural limestone, and the chimney hearth with associated rubble. The east-west rock alignment was located between the northwestern corner of the foundation and the chimney hearth, mostly in units E588+05/N155, E588+10/N155, and E588+15/N155 (Figure 17a; see Figure 15). A concentration of window glass was recorded in the southeastern corner of unit E588+05/N155 (see Figure 15). This ca. 10-ft-long section of foundation consists of both large and small stones with occasional flecking of charcoal.

The chimney hearth foundation and associated rubble were located in units E588+15/N155, E588+15/N160, E588+20/N155, $\mathrm{E} 588+20 / \mathrm{N} 160$, and E588+25/N160 (Figure 17b). The chimney hearth foundation was a squared U-shaped feature with several large tabular limestone slabs, many medium-sized stones, and a greater occurrence of charcoal/ash (see Figure 15). Some of the large slabs showed evidence of burning. Stone rubble associated 


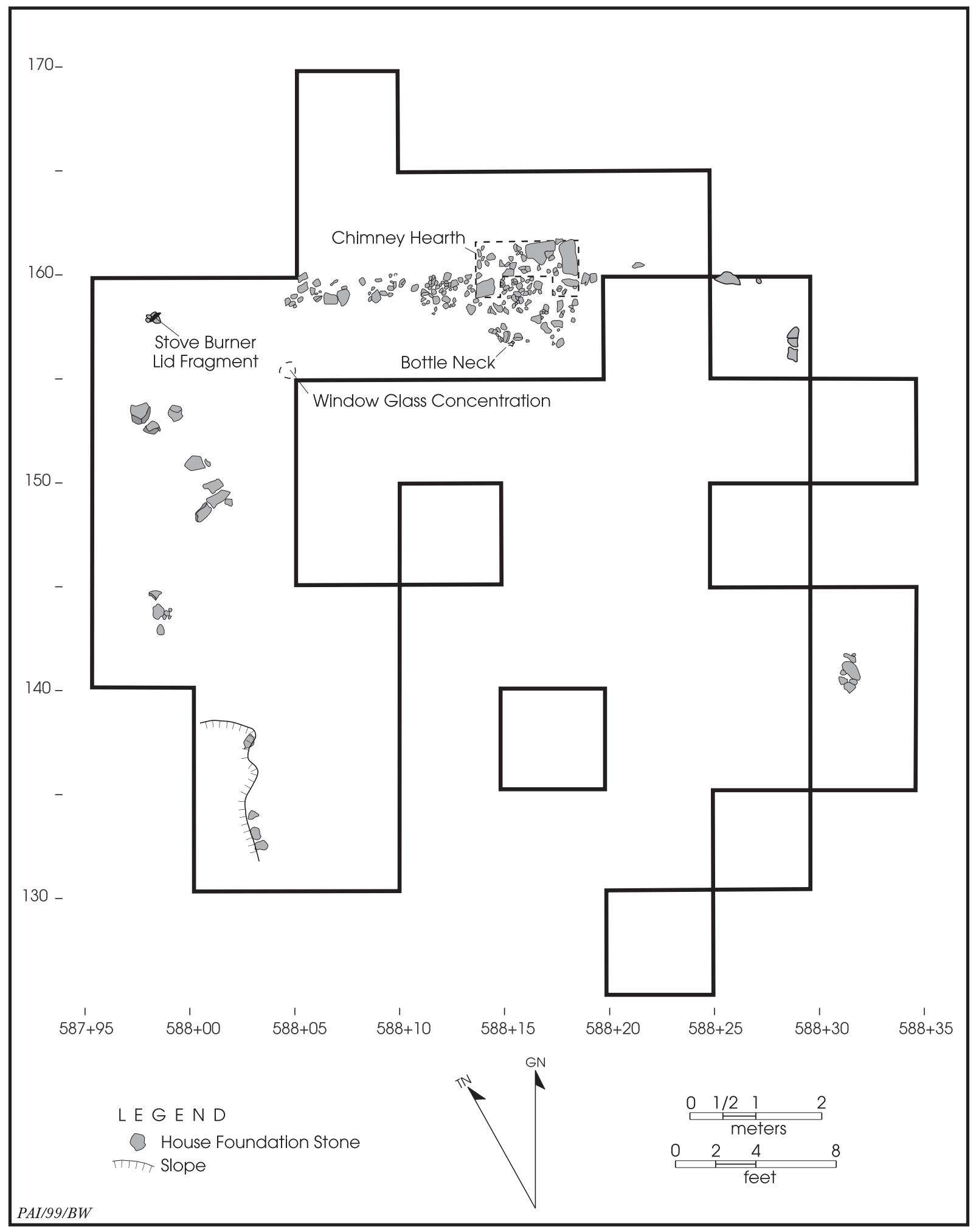

Figure 15. Plan of the chimney hearth and house foundation as exposed in excavations in the core historic area. 


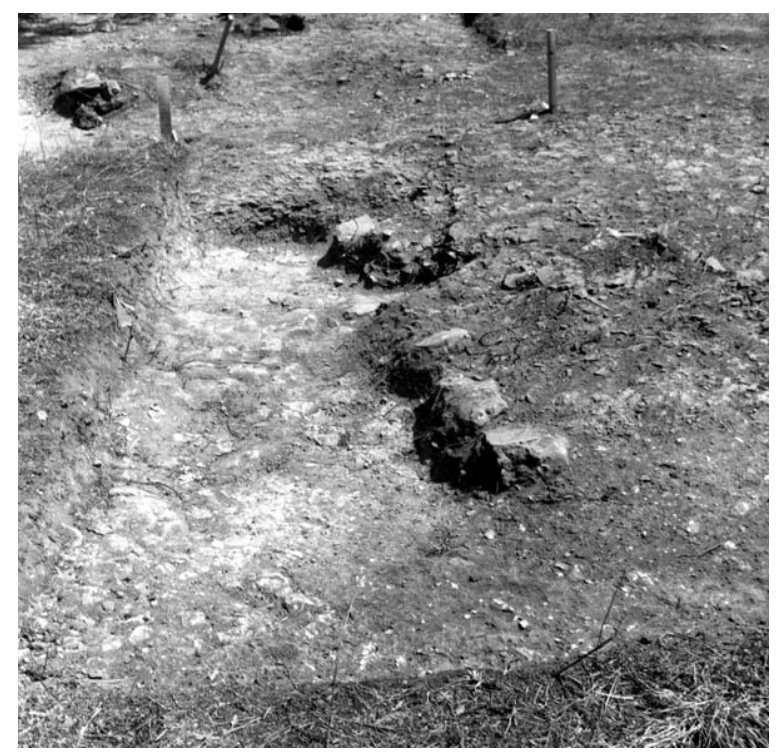

a

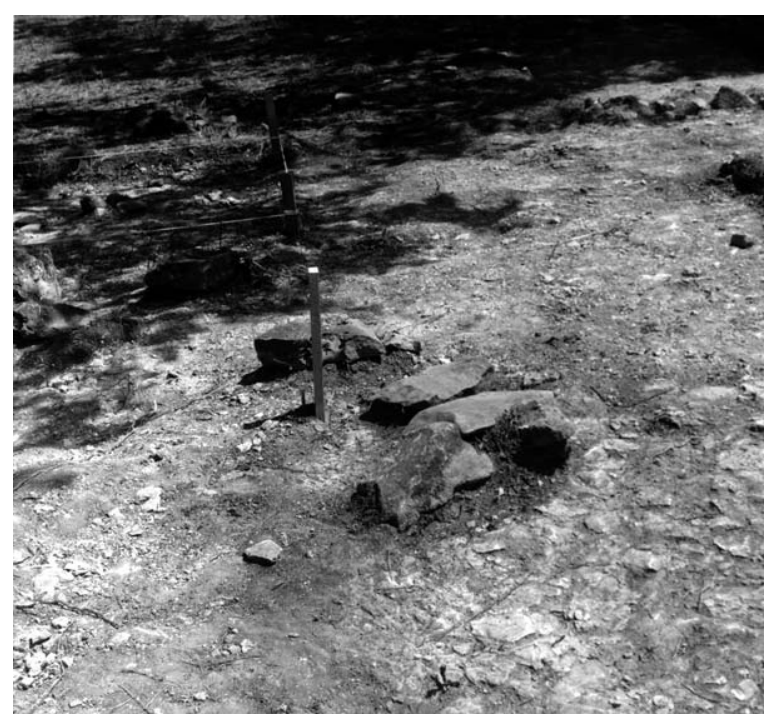

C

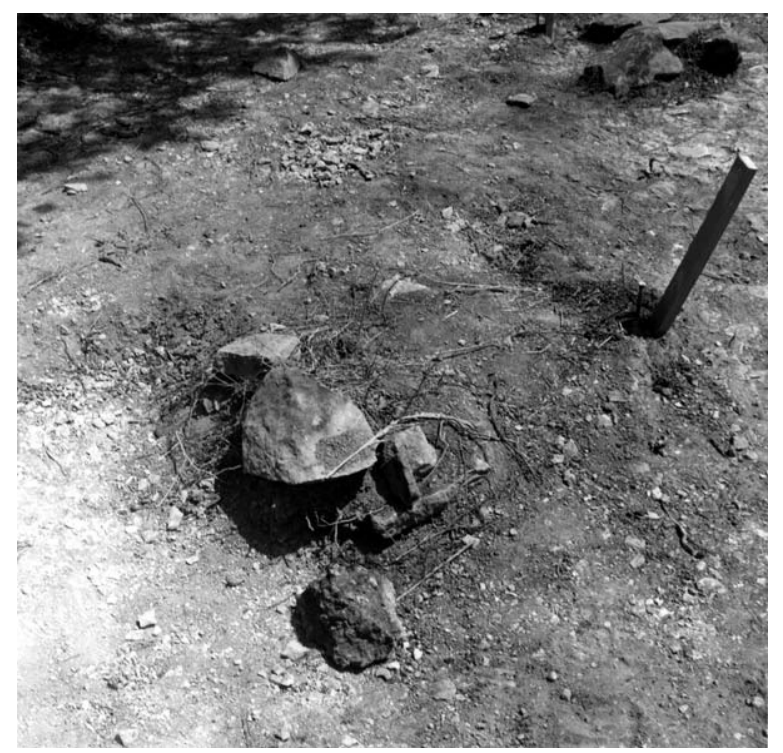

b

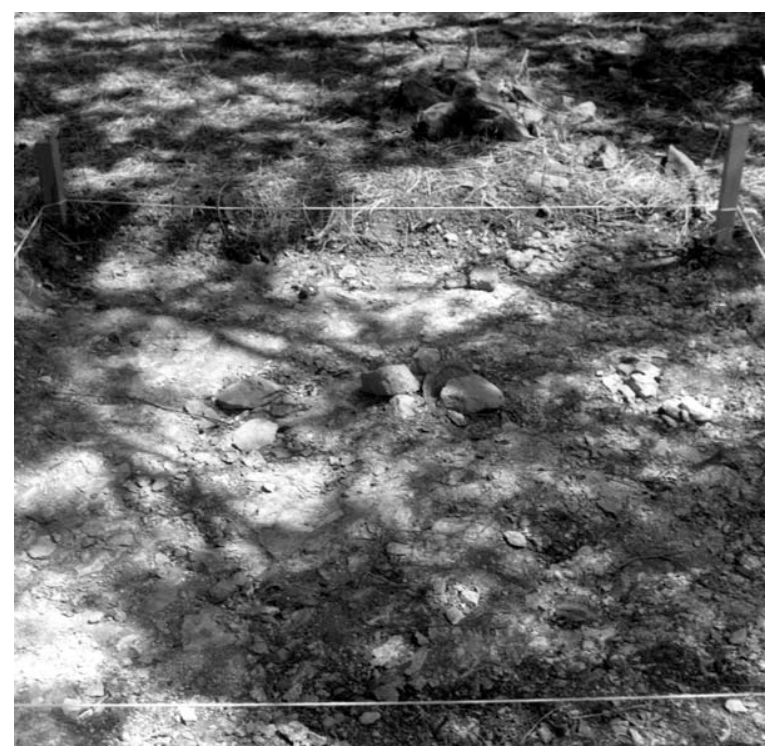

d

Figure 16. Western side of house foundation. (a) Stone alignment in units E588+05/N130 and E588+05/ N135; (b) stone alignment in unit E588+00/N140; (c) stone alignment in units E588+05/N145, E588+05/N150, and E588+00/N150; and (d) stone alignment in unit E588+00/N155.

with destruction of the chimney hearth was scattered primarily to the south of the feature, although small amounts of rubble were present to the east. The rubble consisted mostly of medium-sized stones. A bottle neck was recorded in association with the southernmost extent of the rubble.

Of the three sides of the house represented by rocks, the eastern side was the least well defined (see Figure 15). A feature interpreted as the northeastern corner of the foundation was present in unit E588+30/N155. There were two limestone alignments that formed an L shape. The northern alignment was oriented east-west and consisted of one large stone clustered with several smaller stones. The 


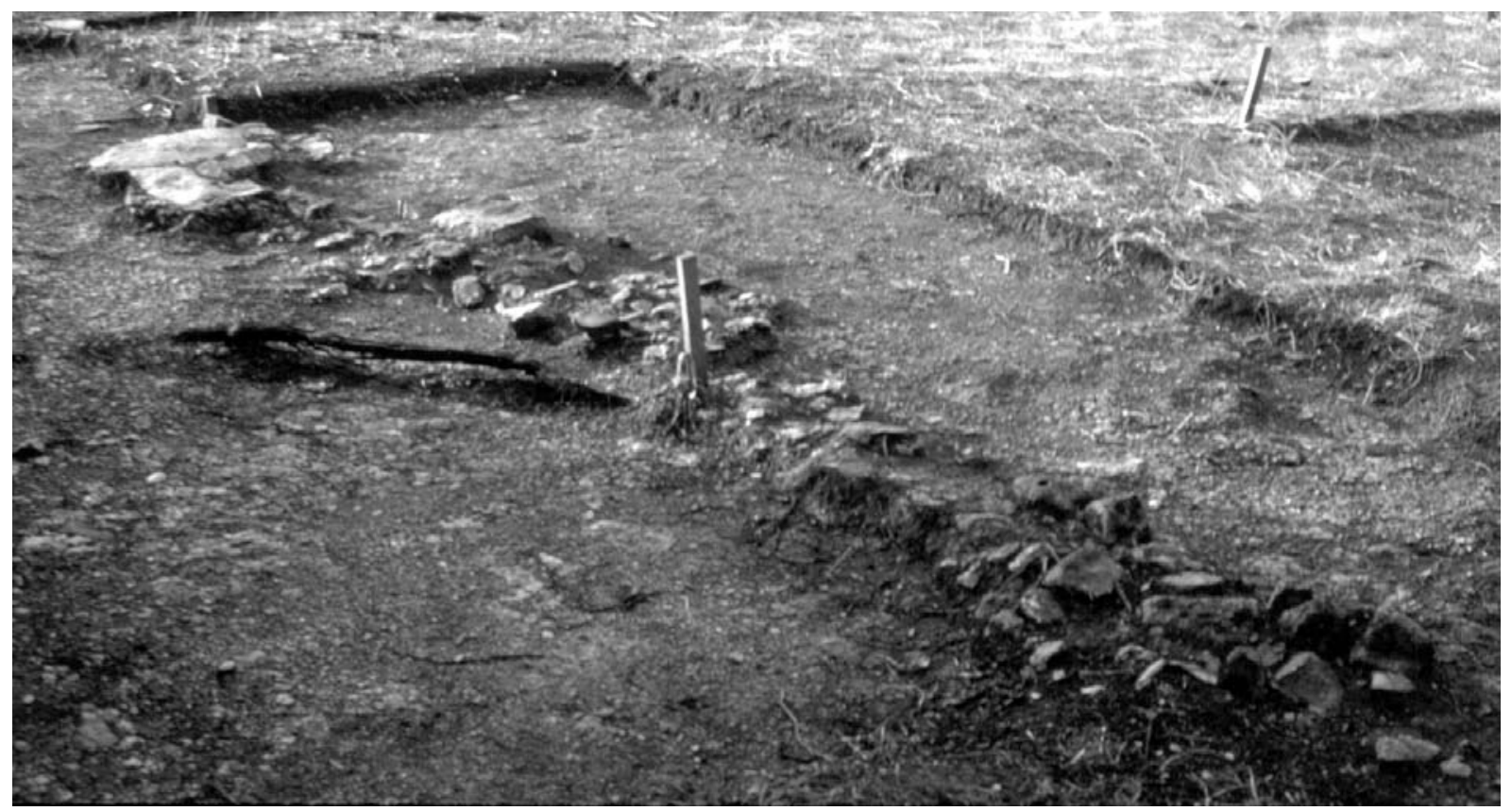

a

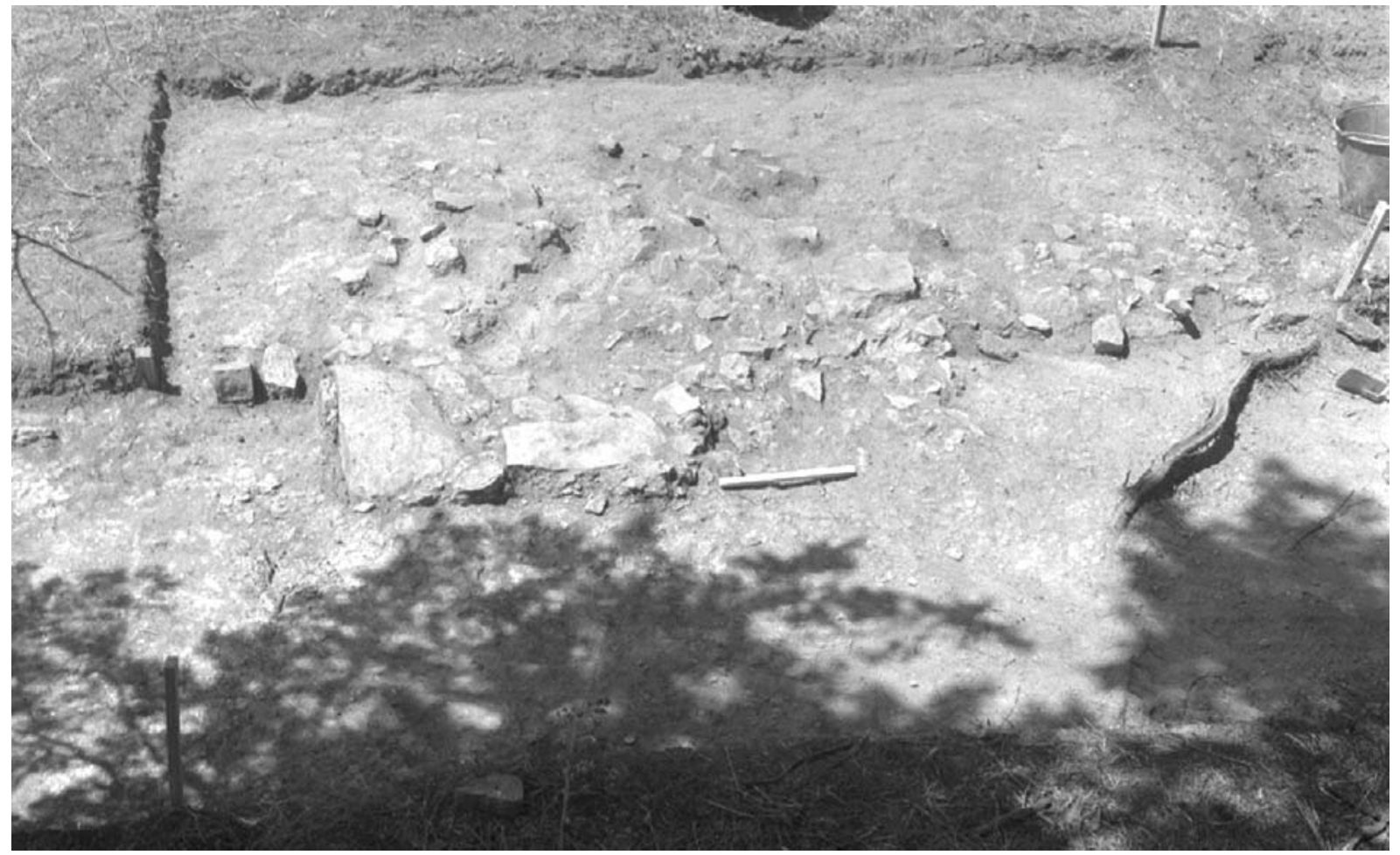

b

Figure 17. Northern side of house foundation. (a) Stone alignment in units E588+05/N155, E588+10/N155 and E588+15/N155, facing southeast; (b) chimney hearth foundation in units E588+15/N155, E588+15/N160, E588+20/N155, E588+20/N160, and E588+25/N160, facing south. 
southern alignment was oriented north-south and consisted of a cluster of small rocks slightly separated from three large adjacent rocks (Figure 18a). The only other extant portion of the foundation on the eastern side of the house was in unit E588+35/N140. It was a dense cluster of ca. eight medium-sized to large rocks (Figure 18b).

While there was no concrete evidence for the southern side of the house foundation, it is assumed that the southernmost western foundation alignment indicates the possible position of the fourth side of the foundation. That would suggest a square structure ca. $30 \mathrm{ft}$ in diameter, although some other shape or orientation remains a possibility.

Artifact distributions also were taken into account when defining the location of the house. Specifically, artifact densities were noted as being higher in areas interpreted as being outside or around the house, whereas artifact densities were lower in areas that would have been under the house. For example, it was noted in unit E588+05/N145 that there were far fewer artifacts in the east half of the unit (i.e., east of the foundation alignment) as compared to the west half.

\section{Fences and Fence Lines}

Five fences or fence lines were identified as surface features. These are important features because they serve to delineate space and define the garden and yard areas. They also may represent different fencing or repair episodes, as evidenced by changes in construction materials over time. Regardless of the types of materials used for construction, alignments of trees were noted and used to indicate where fence lines had been historically, especially in cases where portions of fences had fallen down.

The westernmost fence may have been an original feature at the Rubin Hancock farmstead, or at least one of the older examples. It was located in the northwestern portion of the site and defined that corner of the garden area. It had two sections, was constructed of drylaid stones, and was assumed to be a base for a post and wire fence, such as the one adjacent to it. This was the only section of fence that utilized stone in construction. According to map depictions, the longest section of this fence was oriented north-south and exhibited a slight curve along its length. It was ca. $90 \mathrm{ft}$ long. At its northern end, it made a $90^{\circ}$ turn eastward. The east-west-oriented section was ca. $25 \mathrm{ft}$ long. At one time, this fence line probably continued farther east to form a barrier at the north end of the site and to separate the house area from the east-west road that the fence parallels.

A fence of different construction materials apparently replaced the stone fence at the west end of the site. Located ca. $5 \mathrm{ft}$ east of the older fence, it was constructed of cedar posts and barbed wire. It was straight and oriented along a north-south axis. It was approximately $122 \mathrm{ft}$ long. It probably was built when the older fence was no longer able to serve its intended purpose. This fence, and the older adjacent one, apparently served to separate the cultivated garden area from the surrounding natural wooded area and aided in keeping animals and other trespassers out of the crops.

Another potentially original or older section of fencing was present in the middle of the site. It also was oriented along a north-south axis. It separated the yard from the garden and stretched almost the full width of the farmstead. The fence was constructed of cedar posts and barbed wire. It terminated on its southern end at an animal pen of roughly triangular shape with maximum measurements of $20 \times 35 \mathrm{ft}$. There was a post just north of the pen that had several cut nails in it, which suggests that it was of late-nineteenth-century construction.

Little information is available about the eastwest fence line at the south side of the site, other than the fact that it had an "old gate" at its eastern end. Photographic evidence suggests that it was post and barbed wire. It also may have been contemporaneous with Rubin Hancock's occupation.

Photographic evidence also indicates that more-recent fencing made of metal posts and barbed wire was present at 41TV875. Its exact location, length, and orientation are unknown. It appears to date to the twentieth century.

\section{Yard and Garden Areas}

As mentioned above, one of the primary functions of the fences at the Rubin Hancock farmstead was to define space. The farmyard and garden areas were fenced on the north, west, and south sides. There is no evidence for fencing along the east side of the house. Instead, 


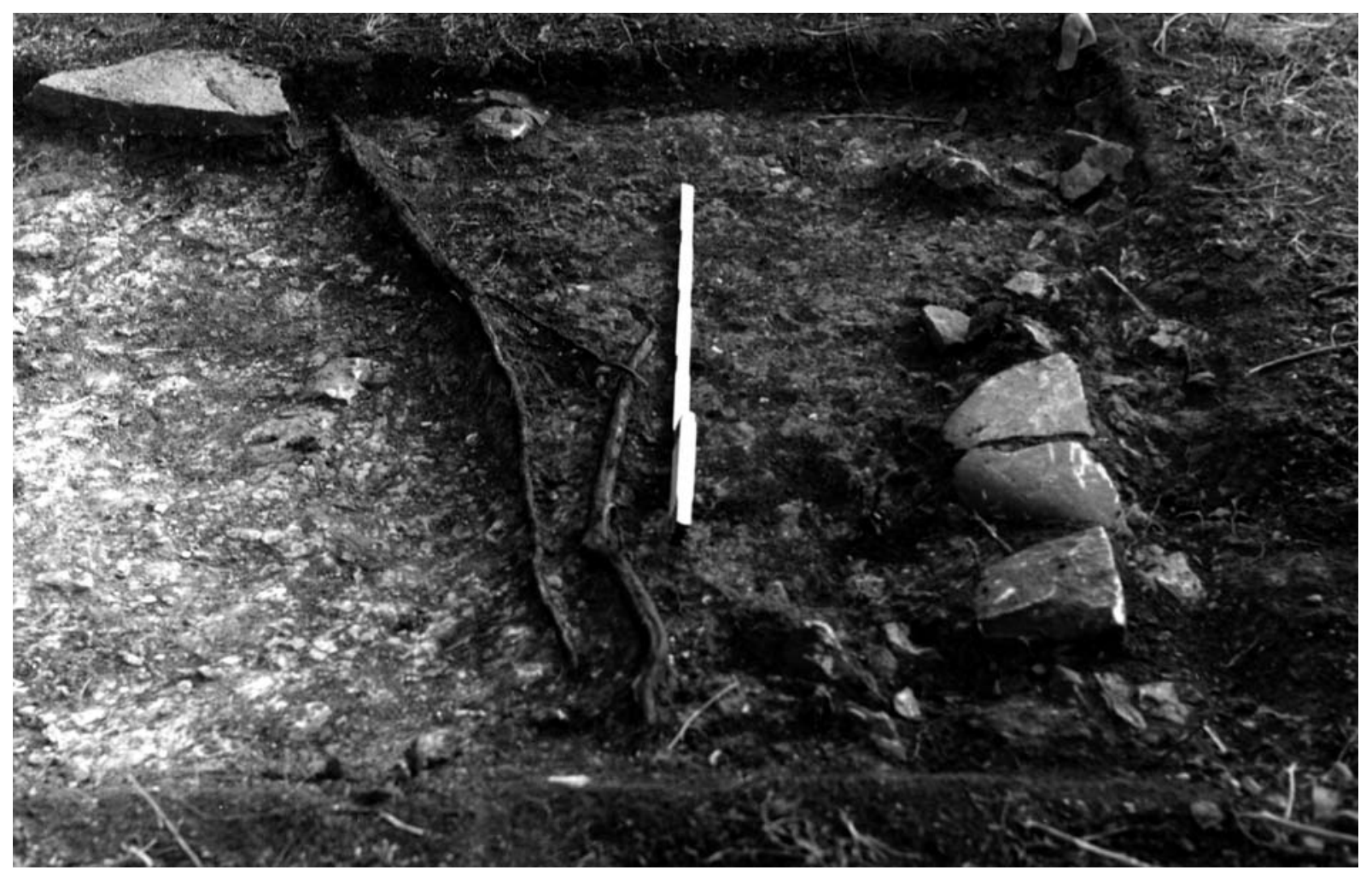

a

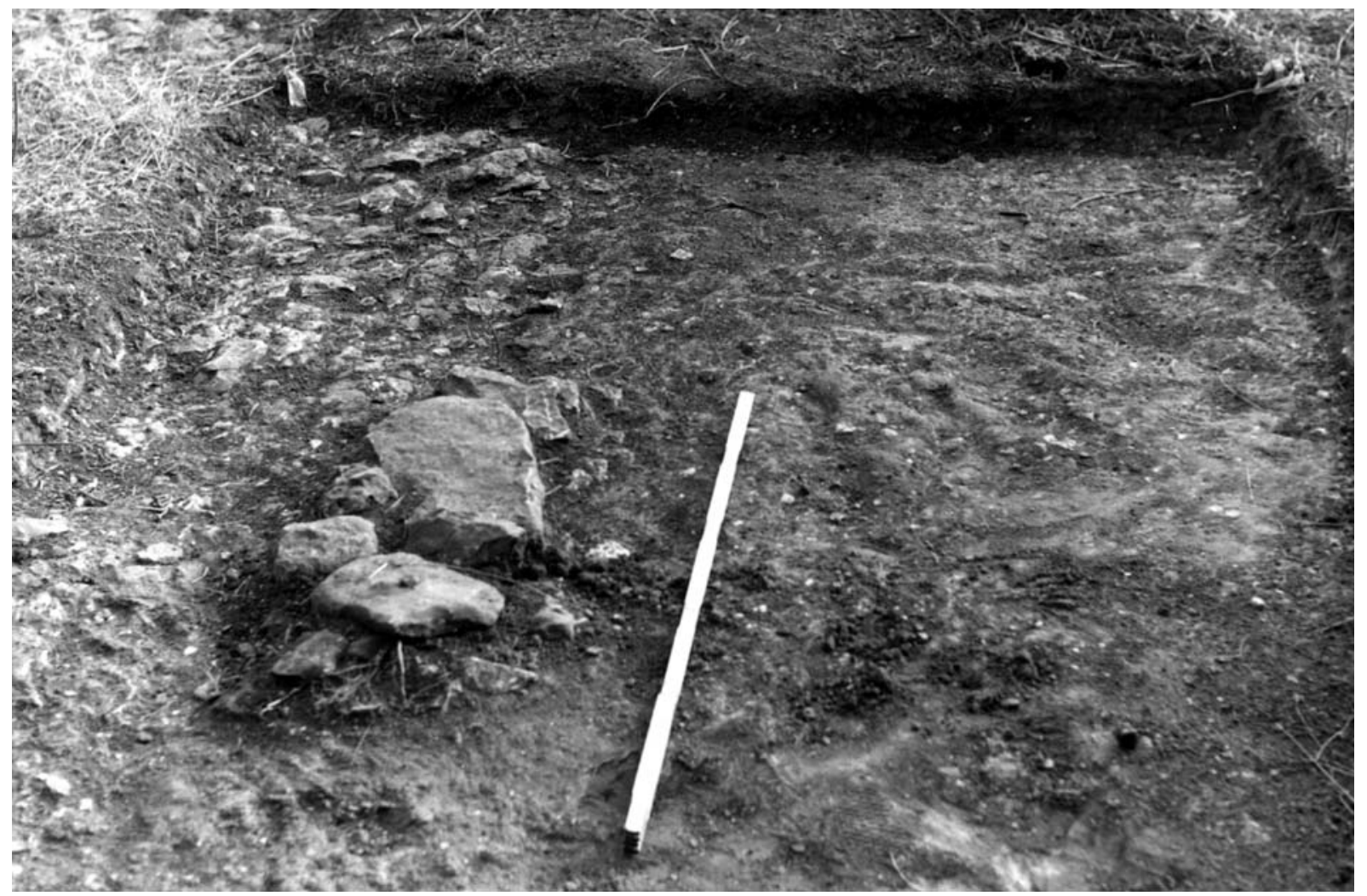

b

Figure 18. Eastern side of house foundation: (a) northeastern corner in unit E588+30/N155; (b) rock cluster in unit E588+35/N140. 
a north-south road defined that side of the site, which probably represented the front of the house. A fence bisected the immediate farmstead area, thus separating it into two functionally different spaces. To the east of the fence was the house, its yard, and farmstead support features (such as the two wells and the animal pen). This area measured roughly $150 \mathrm{ft}$ north-south by $80 \mathrm{ft}$ east-west. The north-south fences were oriented to magnetic north, whereas the house was oriented at approximately $20^{\circ}$ east of magnetic north and the east-west road actually ran ca. $35^{\circ}$ off of a true east-west orientation. This difference of orientation made for somewhat unusual parallelogram-shaped yard and garden spaces.

To the west of the fence was the cultivated garden space. It was similar in size and shape to the yard area, measuring approximately $150 \mathrm{ft}$ north-south by $85 \mathrm{ft}$ east-west. The size of the garden was slightly more than a one-third of an acre. A small cultivated space such as this would have been used to grow produce for home consumption. Other agricultural products for market resale would have been produced in other fields on Rubin Hancock's acreage.

\section{Dog Burial}

A dog burial was encountered during excavation along the northern fence line of the garden area (Figure 19). It was revealed initially in the east wall of Trench 3. Subsequent to its discovery, it was exposed further with the excavation of unit E587+10/ N165. The large animal had been placed in a pit dug in the dark brown sandy loam of the garden. A portion of the body rested on stones, but if that was intentional or coincidental is unknown. Approximately 5 inches of soil had been placed on top of the dog. No artifacts were discovered in association. At some point, the burial was somewhat disturbed by an unknown agent, and portions of the skeleton were disarticulated. The excavators noted that the vertebrae were very arthritic. Subsequent examination of the remains during analysis confirmed the advanced arthritic condition evident in the skeletal remains (Joan E. Baker, personal communication 1999). This suggests that the dog died at an old age and was buried as a beloved family pet.

\section{Trash Dumps}

An area containing dumped historic refuse was observed on the ground surface along the fence that separated the yard from the garden, just north of the animal pen. It was described as having much debris, some of it large, including a pile of barbed, hog, and bailing wire. Some of these items were collected. This dump would have been located in a back/side yard area of the farmstead. The dump was explored with three units: E587+80/N100, E587+85/N90, and E587+85/N95.

Another surface dump area was reported to the north of 41TV875, beyond the formal site boundaries. Little was recorded with reference to its exact location, size, shape, or composition. A collection of diagnostic materials was made $(\mathrm{n}=41)$, which consists primarily of ceramics, glass, and some metal. It was hypothesized that this was a refuse dump location shared by the occupants of Rubin Hancock's household and the neighbors to the north (perhaps the Hansboroughs) (John W. Clark Jr., personal communication 1999). Most of the artifacts are consistent in type and date with the assemblage excavated from 41TV875. However, other artifacts are present which date to the 1930 s

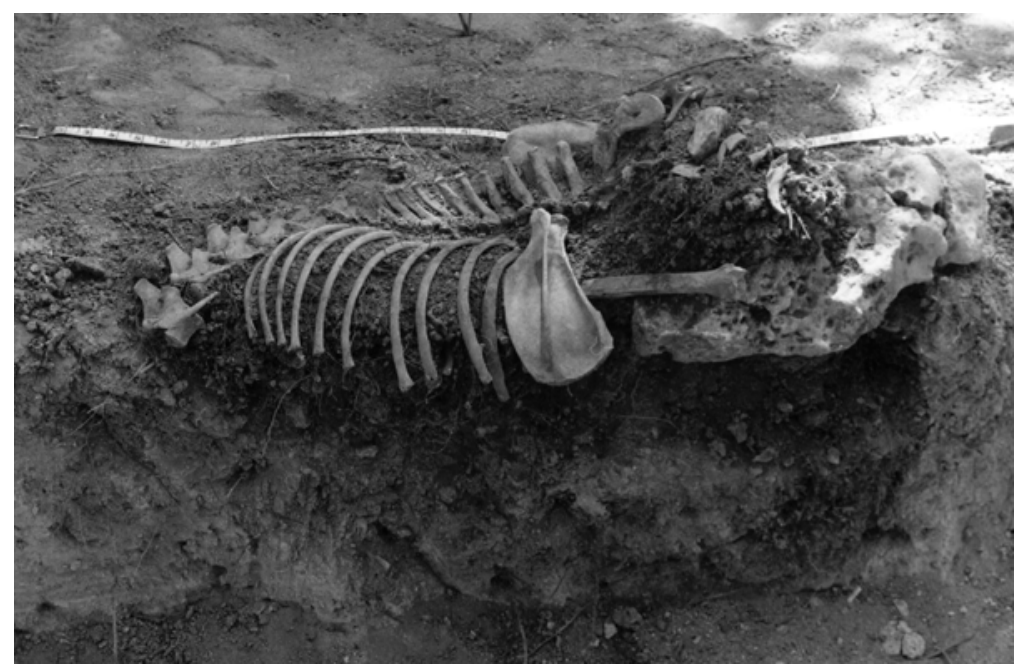

Figure 19. Dog burial in unit E587+10/N165. 
and $1940 \mathrm{~s}$, a period later than that represented at 41TV875. Although it is possible that some of the materials are from the Hancock household, it appears to be a mixed assemblage with insufficient information to allow for separation of components. The interpretation of these artifacts is limited due to their unclear associations.

\section{Possible Outbuilding Foundations}

Although not recorded as formal features on record forms, two unidentified rock concentrations/alignments were mapped. The first of these was a rock concentration noted across three units located south of the house foundation at E588+55/N50, E588+55/N55, and E588+60/N50 (Figure 20). A plan drawing and photographs of the concentration were made, but no other details, interpretations, or identifications were offered. The feature consisted of a rock alignment and an associated cluster of rocks located in an area of extremely thin soils. The alignment was in units E588+55/ $\mathrm{N} 50$ and E588+60/N50. It was oriented northeast-southwest and was made up of 14 medium-sized rocks. Directly north of the western end of the alignment was a cluster of 7 medium-sized to small rocks located in unit E588+55/N55. Alignments and clusters of this sort are the archeological signatures interpreted as the foundation for the house elsewhere on the site. Following that example, it is possible that this rock feature represents a foundation for an outbuilding.

A similar alignment feature was recorded in unit E588+40/N100. It was an L-shaped alignment oriented along the same axis as the house foundation. The north-south segment, measuring ca. $2.5 \mathrm{ft}$ long, consisted of 19 medium-sized and large stones, including 2 prehistoric lithic cores. The east-west alignment consisted of 6 medium-sized and small stones. Again, it is possible that this represents the corner of a foundation for an outbuilding.

Farms typically have a variety of

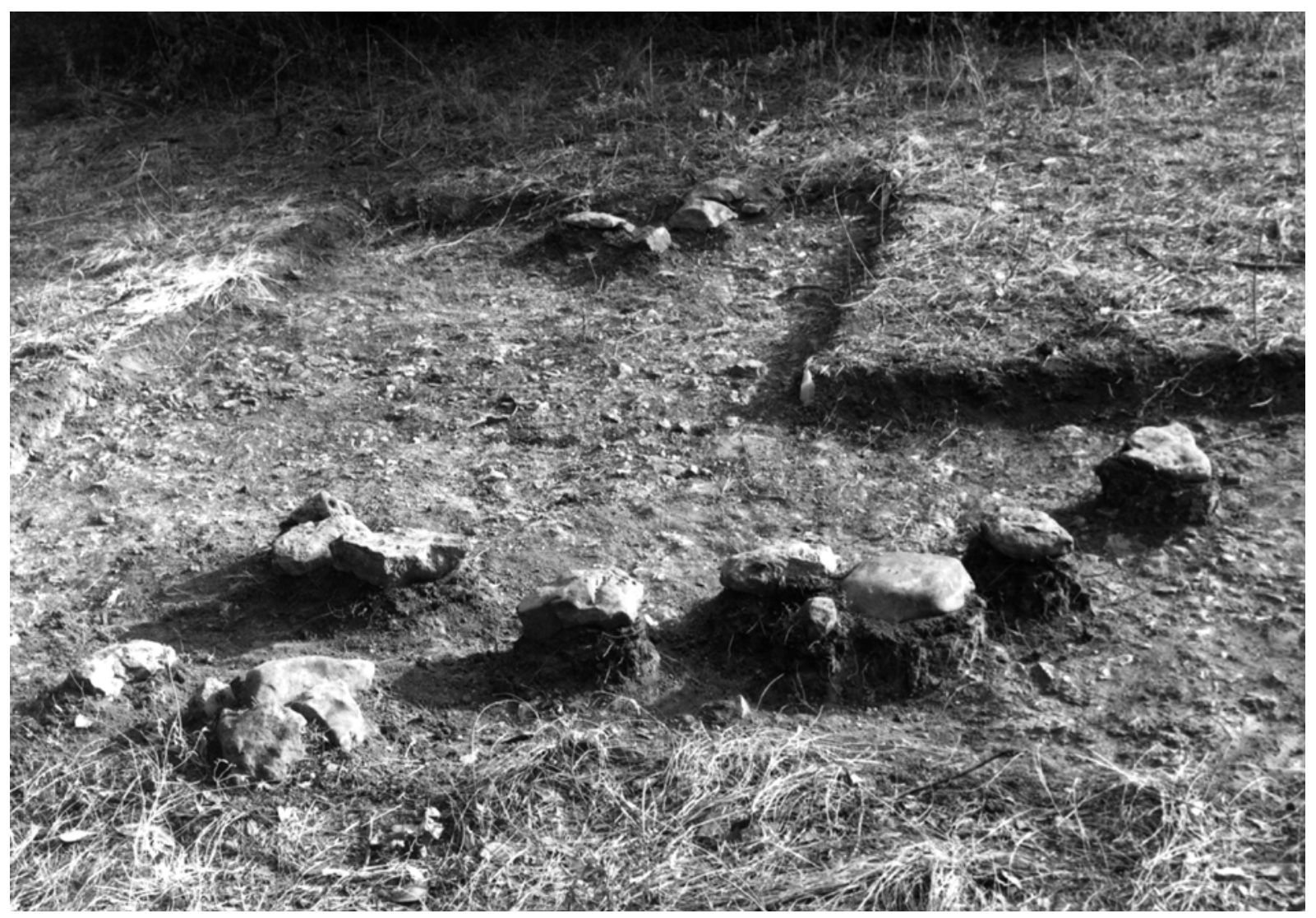

Figure 20. Possible outbuilding foundation in units E588+55/N50, E588+55/N55, and E588+60/N50. 
outbuildings or support features associated with agricultural activities, some of which are commonly located in the yard. Few such buildings were identified at 41TV875. The two features described above were located in an area of the yard obviously utilized as an activity area, as evidenced by the presence of the two wells and the animal pen. These rock features could represent the remnants of square or rectangular foundations. The southern of the two would have had a minimum interior space of $6 \mathrm{ft}$ and would have been oriented along the same north-south axis as the fences. Such outbuildings may have served as sheds, storage buildings, or similar structures.

\section{Pit Feature}

Another feature for which only a tentative identification can be made is the pit feature encountered in unit E588+45/N160 (Figure 21). This location was east-northeast of the house foundation in an area of thin soils. The excavators noted a depressed area in most of the unit. Plan view and profile drawings were made, and a photograph was taken. No other interpretations or information was offered. The

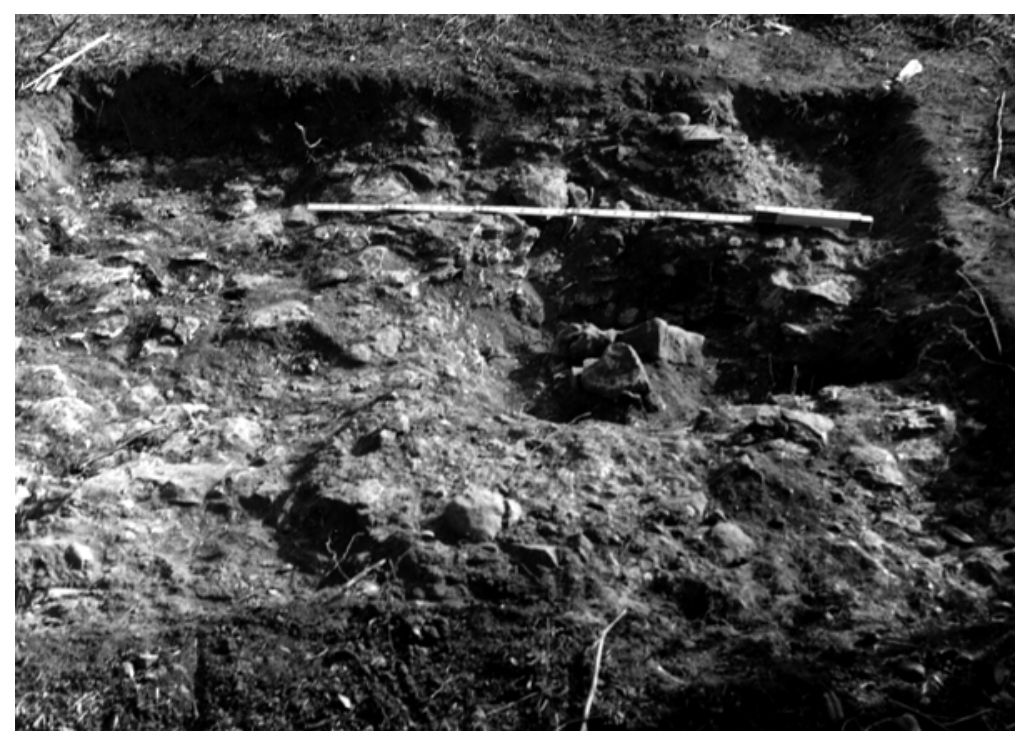

Figure 21. Pit feature in unit E588+45/N160. feature was circular to ovoid in plan, with an average diameter of ca. $2 \mathrm{ft}$. The east side was somewhat elongated. In cross section, the feature was ca. 6 inches deep and basin shaped with a flat bottom and sloping sides. It appeared to have been excavated out of the eroding limestone bedrock, or perhaps it utilized a natural depression. Approximately four medium-sized rocks were present in the bottom center of the pit. Three more medium-sized rocks, including two burned ones, were recorded lying on bedrock immediately north of the pit. A concentration of ash measuring $0.75 \times 1.5 \mathrm{ft}$ was present east of those rocks. The exact nature of the feature fill is unclear because the sediments removed from the pit and from the rest of the unit were not separated from one another.

It is not possible to make a definitive identification of this feature. However, several factors can contribute to a tentative interpretation. Its location within the core historic area suggests that the feature was historic in origin rather than prehistoric. The pit shape as well as the presence of burned rocks and ash indicate that it might have been a burn pit of some sort. The fact that the burned rocks and ash were adjacent to, rather than inside, the pit points to a possible cleaning episode. The relatively small size, lack of evidence of more intensive burning, and lack of burned artifacts argue against habitual burning activities at this location, such as the burning of trash. Instead, it appears that this represents an activity that was performed only once in this location and then moved to another part of the yard, or a seldom-practiced or specialized activity. Examples of these might include burning of trash in a barrel, boiling laundry, manufacture of soap or candles, smoking small batches of meat, scalding hogs, or outdoor cooking. 



\section{ARTIFACTS}

\section{ANALYSIS METHODS}

The historic artifacts recovered were processed and cataloged by the SDHPT laboratory after the excavations were completed. However, because some of the methods used at that time do not meet current curation standards, the materials were repackaged for curation at TARL. The original bags and all original designations, descriptions, identifications, and notations associated with the artifacts were retained during laboratory processing by Prewitt and Associates.

During analysis, all of the historic materials were sorted to determine which artifacts have interpretive value. The guiding principal utilized to decide which artifacts should be kept and which ones should be analyzed in depth was an assessment of the diagnostic characteristics of the materials. Artifacts that potentially could provide information relevant to temporal and/ or functional questions were selected for analysis.

All ceramics were examined. In general, ceramic as a material is extremely durable and survives well in archeological contexts. Therefore, diagnostic attributes that allow for dating and identification of function usually are present. Also, there are copious published comparative data on ceramics of all sorts, making them that much more useful in analysis.

Glass also survives relatively well in archeological contexts and, therefore, was studied. As a material, glass typically falls into three functional categories-container, tableware, and window glass. The study of container glass (especially marked examples) can be especially informative for questions of consumer behavior and consumption patterns.
Glass (and ceramic) tableware can be examined in terms of foodways. On a site such as 41TV875 with somewhat limited surviving architectural evidence, the presence (and potential patterning) of window glass can be helpful in reconstructing the presence and placement of house windows.

Ferrous (and other) metal is a somewhat problematic material. Because of rust and corrosion, it does not survive nearly as well as ceramics and glass in archeological contexts, and diagnostic attributes often are lost. Metal also continues to degrade over time. Metal that is highly fragmented or unidentifiable due to rust has little interpretive value, and such items were not considered worthy of close examination. However, metal items (such as buttons, furniture hardware, clothing fasteners, etc.) that retained their diagnostic attributes and were identifiable, were studied. Tin can fragments were analyzed only if complete enough to indicate manufacturing method. Nails (both cut and wire) were not subjected to special study because they occur in such large quantities, vary so little between individual specimens, and provide limited information once they have been identified. Although faunal remains can be important because of the information they supply about foodways, the small collection from 41 TV875 was not subjected to formal analysis.

Although not all of the historic artifacts were selected for detailed study, all artifacts were included in the analysis (excluding abundant modern trash from the hand-dug well). As many artifacts were identified as possible, although some have insufficient diagnostic attributes to allow for functional identification. In such cases, material type 
identifications were utilized. All artifacts were quantified by count; none were quantified by weight. Analysis focused on materials with the greatest amount of diagnostic information as a way to address temporal, spatial, and functional questions.

The data were managed utilizing a spreadsheet organized by provenience and artifact categories. The provenience data included lot numbers, unit northing and easting coordinates, and level designations. Artifact categories were defined by both the material and functional categories most represented at the site. The major artifact categories were ceramics, table glass, container glass, metal, buttons, personal attire and belongings, architectural, farmstead, household and furnishings, faunal, and unidentified/other. All artifacts recovered from the Rubin Hancock farmstead are summarized in the Appendix.

Data were entered directly by the analyst. During the course of the analysis, some of the original information recorded by SDHPT personnel was reassessed. For example, some artifacts that originally had been unidentified were classified functionally during the current analysis. In other cases, some of the original identifications provided for the artifacts were felt to be inaccurate. In those cases, the identification was changed to a different, moreaccurate identification or listed as unidentified, as appropriate. Finally, some identification changes reflected an update in terminology utilized to describe materials (especially glass).

\section{OVERVIEW OF THE ASSEMBLAGE}

A total of 9,086 historic artifacts were recovered from the excavations at the Rubin Hancock farmstead. These are summarized in Table 2.

The assemblage is dominated by tin can fragments and container glass sherds, primarily from bottles and jars. While both of these classes of artifacts potentially can provide information on the date of occupation, trade networks, and foodways, most of these artifacts are of limited diagnostic value since they are represented primarily by fragments of the container body. The ceramics group, which typically is highly informative, is only 4 percent of the total assemblage and contains few decorated, marked, or otherwise diagnostic sherds. In this assemblage, wire fragments (ca. 6 percent) make up a larger percentage than do the ceramics. Cut and wire nails combined constitute almost 25 percent of the assemblage. The proportion of cut to wire nails can be very important for site interpretation, and in this case, it supports the age of the occupation derived from the archival and oral history data.

\section{CERAMICS}

The 360 ceramic sherds consist of a limited variety of refined wares and utilitarian stonewares. Systematic crossmending of ceramic sherds was not undertaken and, therefore, the minimum number of vessels is not known. However, selected crossmending was undertaken for the most diagnostic ceramics.

The assemblage consists of 65 percent $(n=$ $235)$ refined ware types. Refined wares are defined as undecorated whiteware/ironstone $(\mathrm{n}=$ $140)$, undecorated semiporcelain $(\mathrm{n}=1)$, latestyle transfer-printed whiteware $(\mathrm{n}=12$, including the Willow pattern), and porcelains ( $\mathrm{n}=82$, including both bone china and hard-

Table 2. Summary of historic artifacts from 41TV875

\begin{tabular}{lcc}
\hline Artifact Group & $\begin{array}{c}\text { Number of } \\
\text { Artifacts }\end{array}$ & Percentage \\
\hline Ceramics & 360 & 4.0 \\
Table Glass & 54 & 0.6 \\
Container Glass & 2,063 & 22.7 \\
Tin Cans (fragments) & 2,069 & 22.8 \\
Miscellaneous Metal & 258 & 2.8 \\
Household and Furnishings & 83 & 0.9 \\
Cut Nails & 1,532 & 16.9 \\
Wire Nails & 686 & 7.6 \\
Window Glass & 419 & 4.6 \\
Miscellaneous Architectural & 59 & 0.6 \\
Personal Belongings and Attire & 217 & 2.4 \\
Fence Staples & 74 & 0.8 \\
Wire Fragments & 519 & 5.7 \\
Miscellaneous Farmstead & 60 & 0.7 \\
Faunal & 508 & 5.6 \\
Unidentified/Other & 125 & 1.4 \\
\hline
\end{tabular}


paste porcelain). Most of the refined ceramics appear to represent table and tea wares, with little evidence for toilet or kitchen ware vessel shapes. A limited number of decorative styles are evident, including only late-style transfer printing and enameling (over-glaze hand painting).

The remaining 35 percent $(n=125)$ of the ceramics consist of utilitarian ceramics. All utilitarian ceramic forms recovered are stoneware. No unrefined earthenwares were recovered. Slip-glazed stoneware, salt-glazed stoneware, and yellowware are the types represented. Limited crossmending was done by SDHPT, and vessel forms within the assemblage include a mixing bowl,jugs, probable crocks/jars, and a German mineral water bottle. None of the utilitarian wares have additional surface decoration.

\section{Makers’ Marks}

Seven fragmentary makers' marks are present. Two marks on undecorated whiteware sherds are fully identifiable (Figure 22). The first is a black-printed Royal arms-style underglaze mark with the partial word "...IN"

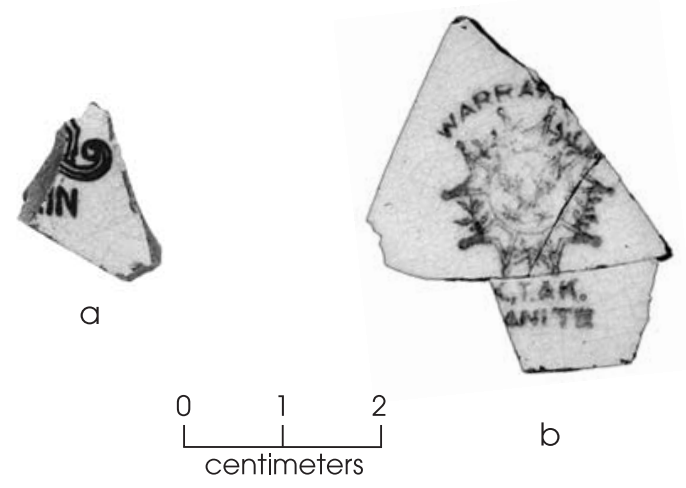

Figure 22. Ceramic makers' marks. (a) Charles Meakin ; (b) Knowles, Taylor and Knowles.

(Figure 22a). This mark was used by the British manufacturer Charles Meakin from 1876 to 1889 (Praetzellis et al. 1983:55, 102).

The second identifiable mark consists of three crossmending undecorated whiteware sherds from units E587+55/N160 and E587+55/ N155. It is a black-stamped mark underglaze with a stylized star motif surrounding an eagle. The word "WARRAN..." arches over the top, and the words "K.T.\&K./...ANITE" run on two lines below (Figure 22b). This mark was used by the American company Knowles, Taylor and Knowles from ca. 1890 to 1907 (Gates and Ormerod 1982:119).

Because these two periods of ceramic production do not overlap, these two vessels (and likely others) may represent two different acquisitions of household ceramics, perhaps even the purchase of replacement pieces as older vessels were broken during use. It also is interesting to note that the older mark represents a British product whereas the newer mark represents an American product. This trend closely mirrors the development of the American ceramics industry at the turn of the century that displaced the British as the dominant supplier of ceramics to America (Gates and Ormerod 1982:5).

Three other marks are partially identifiable. It is not possible to identify the specific manufacturers, but the marks do supply other information about the vessels on which they appeared.

A hard-paste Japanese porcelain cup plate was crossmended from 46 sherds recovered in unit E587+15/N5. It is decorated with a floral design that is enameled in blue, green, reddish orange, and dark yellow (Figure 23). Small amounts of gilding survive around the rim of the cup-plate. Both the vessel form and the presence of gilding indicate that this piece was manufactured for export rather than as a traditional Japanese ceramic type.

The cup-plate bears an almost illegible mark on the back that reads "MADE / IN / JAPAN" in green. Generally, a mark such as this specifying the country of origin postdates 1891 , when such a designation was included to comply with the American import laws of the McKinley Tariff Act (Godden 1964:11, 427). However, some references state that from 1891 to 1921 wares exported from Japan were marked "Nippon" and only after 1921 was the phrase "Made in Japan" used to mark wares (Majewski 1996:807). Although this is the conventional wisdom on the topic, there is archeological evidence to the contrary. Japanese hard-paste porcelains marked "Japan" or "Made in Japan" have been recovered from a 1915 context in Walnut Grove, California (Costello and Maniery 1988:27), from 


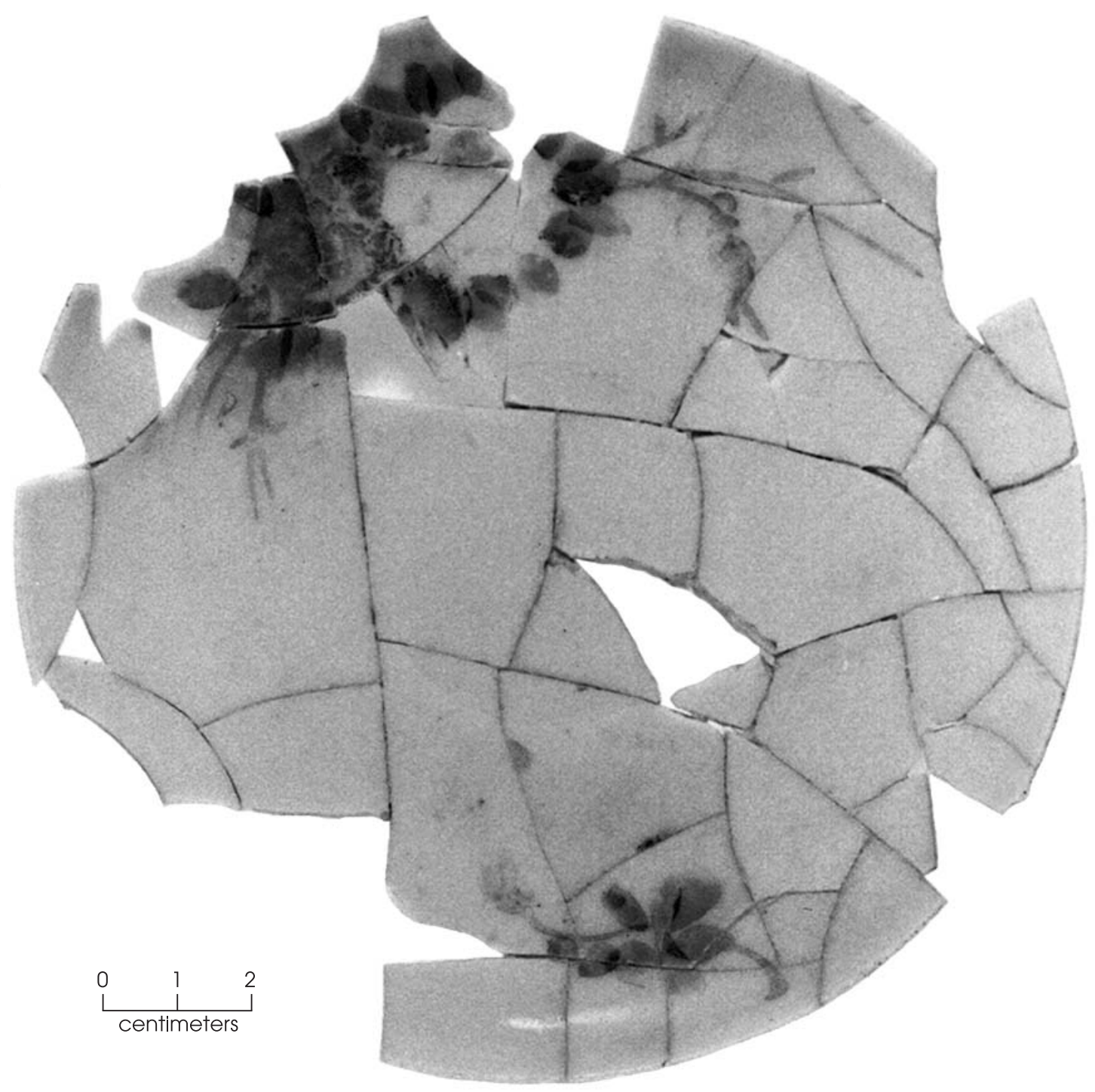

Figure 23. Hand-painted Japanese porcelain cup-plate.

a pre-1915 context in Arizona (Teague 1980:72), and from a 1907-1910 context in Ventura, California (Bente 1976:462). Therefore, the most likely date for the example from 41 TV875 is ca. 1900-1916.

The other two sherds with partially identifiable marks were recovered from units E588+20/N80 and E588+05/N130. Both are fragmentary impressed marks from a single German salt-glazed stoneware bottle. The mark would have been located near the shoulder of the bottle. It has inner and outer circles which contain the letters "...-WO..." and "...-M..." around the circumference. Below the circular mark are at least two lines of text. The letters "...RE..." occur on the first line. Fragments of the body and neck also were recovered. Although the cylindrical German bottle is a commonly recognizable nineteenth-century vessel form, the mark recovered from 41TV875 does not match any of the known marks reported in the literature (Munsey 1970:138-139; Schulz et al. 1980:15, 116; Switzer 1974:15; Wilson 1981:32). German cylindrical stoneware bottles typically 
contained gin, various liqueurs, or, more commonly, mineral water. Mineral waters of all sorts were valued in the nineteenth century for their reputed medicinal value. Those from Germany were most popular from ca. 1870 until World War I.

The remaining two marks are too fragmentary to provide substantive information. One was recovered from unit E587+55/ N160 (the same provenience as the Knowles, Taylor, and Knowles mark). It is a black mark printed underglaze on whiteware. It is a rampant Royal Arms-style mark (like the Charles Meakin mark). However, British, American, and foreign manufacturers used Royal Arms-style marks widely during the nineteenth and twentieth centuries (Godden 1964:552). The other mark was recovered from unit E587+60/N150. It consists of three crossmending undecorated whiteware sherds. The curved edge of an impressed mark is visible but too fragmentary to identify.

\section{Utilitarian Stonewares}

The only utilitarian vessel forms recovered from 41 TV875 are stoneware $(n=115)$ and yellowware $(n=10)$. With the exception of the salt-glazed German mineral water bottle discussed above, the vessels all appear to be hollowware forms designed for preparation, cooking, and storage of foodstuffs.

Yellowware, although technically a partially vitrified, buff-colored earthenware with a clear glaze (Sussman 1997:77), is functionally most similar to stoneware. The sherds of yellowware from 41TV875 appear to represent a single vessel-a mixing bowl. The sherds were recovered from units $\mathrm{E} 587+55 / \mathrm{N} 160(\mathrm{n}=1)$, $\mathrm{E} 587+25 / \mathrm{N} 160(\mathrm{n}=5), \mathrm{E} 587+00 / \mathrm{N} 160(\mathrm{n}=3)$, and the dump location north of the site $(n=1)$. The bowl has a simple hemispherical shape with a slightly thickened lip. A white slip glaze is present on the interior surface, and no other decoration is present. Although both British and American manufacturers produced yellowware vessels with white slip interiors, it is more commonly seen in the English examples (Leibowitz 1985:101, 105). Yellowware production began in England in the late 1820s, and was produced by British and American potters to the 1930s (Leibowitz 1985:9). The undecorated example from this assemblage probably dates to the turn of the century.

The remainder of the utilitarian wares consist of stoneware with a dark brown slip glaze on the interior and exterior surfaces. Greer (1981:197) notes that this glazing combination became especially popular in American stoneware manufacture during the last quarter of the nineteenth century. Although it is extremely difficult to determine an exact point of origin for such common stoneware types, Texas had a productive stoneware industry from the mid-nineteenth century to the early twentieth century that would have supplied the local needs for utilitarian vessels. In 1900, a stoneware pottery was present in Falls County, only three counties northeast of Travis County (Lebo 1987:122).

One of the more interesting examples of slip-glazed stoneware from 41TV875 is a rim sherd that features a hole for a bail handle. A vessel such as a batter jug or other similar form would have been fitted with attachments for a bail handle to facilitate pouring (Greer 1981:7879). Batter jugs typically had lids as well. This rim does have a lip or ledge upon which a lid would rest.

\section{GLASS}

With a few exceptions, the glass artifacts examined fall into three major categories: table glass, container glass, and window glass. Although all are of the same material type, their functions are vastly different and, therefore, are discussed separately. Table and container glass are addressed in this section, while window glass is included in the discussion of architectural items.

\section{Table Glass}

Glass tableware is defined as those vessels associated with the consumption of food or drink, such as tumblers or serving dishes, as well as decorative glass forms such as vases (Jones and Sullivan 1989:127). Glass tableware would have been used in conjunction with ceramic or other tablewares. A small, but interesting, group of glass tableware $(n=54)$ was recovered from the Rubin Hancock site. Glass types represented are clear/colorless sodalime glass $(n=20)$, clear/colorless lead glass $(n=$ 4 ), opaque white glass ( $\mathrm{n}=5$, also called milk 
glass), solarized glass ( $\mathrm{n}=20)$, and pinkish red flashed glass $(n=5)$. All vessels exhibit mold manufacture, particularly press molded.

The most interesting specimens are the four sherds of lead glass. There are two crossmends among the four sherds, and all sherds belong to a single hollowware vessel. Unfortunately, not enough of the vessel is present to make a morespecific determination of either vessel type or pattern.

Lead glass commonly was used for the production of pressed tablewares until the 1860 s, when it generally was superceded by the use of cheaper soda-lime glass (Jones and Sullivan 1989:12). Lead glass was still used for tablewares after the $1860 \mathrm{~s}$, but it was much more expensive than the soda-lime glass equivalent and, therefore, more of a status item. Because the Hancocks had been slaves, it is unlikely that they would have been in possession of older/antebellum "heirloom" items after emancipation. Thus, it appears that they acquired at least one piece of fine lead glass tableware for their own household during their tenure at the farm.

Other less expensive glass tablewares also would have lent to the presentation of a socially acceptable late-Victorian household. At the turn of the century, American manufacturers produced pressed table glass in a large array of vessel types, decorative patterns, and colors (Mace 1991:50-51). A variety of different patterns are present in the Hancock assemblage. None of the patterns have been identified, and most appear to be hollowware vessels. This suggests that, instead of owning a set of matched table glass, different patterns and/or colors were used together as complementary vessels.

Although it was not possible to identify most of the glassware vessel forms, one of the artifacts provides a potential vessel identification. A glass bottle stopper was recovered from unit E588+05/N135 (Figure 24). This example is an undecorated "mushroom stopper," which is characterized by a flat finial that sits horizontally on a neck (Jones and Sullivan 1989:155). The shank of the stopper has been ground to fit the bottle for which it was manufactured. This indicates that the stopper is a closure from a tableware vessel rather than from a commercial container, as the latter more commonly were sheathed in cork rather than ground to aid in a tight fit. The cost of manufacturing glass closures for commercial containers made it generally prohibitive, although they were used for some products (Jones and Sullivan 1989:152). In tablewares, glass stoppers most frequently were used on decanters and cruets (Mace 1991:49, 106). Therefore, such a vessel is probably one of the unidentified glass tablewares in the assemblage.

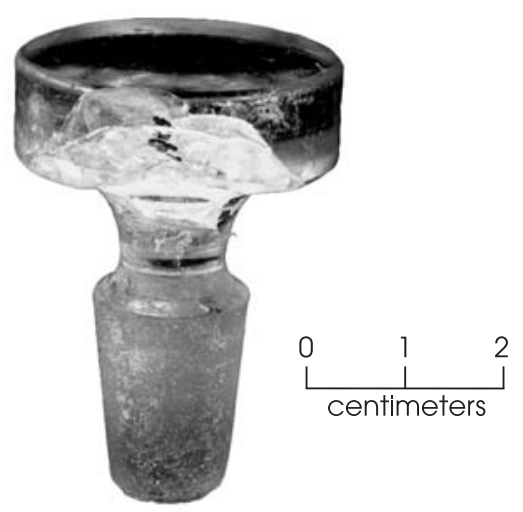

Figure 24. Glass tableware bottle stopper.

\section{Container Glass}

The 2,063 sherds of container glass make this artifact category one of the largest in the assemblage. Colors of container glass include clear/colorless $(n=895)$, olive green $(n=103)$, amber/brown ( $\mathrm{n}=242)$, aqua $(\mathrm{n}=402)$, solarized $(\mathrm{n}=360)$, cobalt blue $(\mathrm{n}=45)$, and opaque white/ milk glass $(\mathrm{n}=16)$. No systematic crossmending of container glass sherds was undertaken to calculate a minimum number of vessels present in the assemblage. While body sherds make up most of the container glass, the finishes, bases, and embossed markings were examined to gain a better understanding of the types of containers, their contents, and manufacturers. Examples of the most diagnostic items are discussed below as representative of the assemblage as a whole.

The oldest specimens are the olive green glass sherds $(n=103)$. Dark olive green glass typically was used for making bottles holding 6 ounces or more and is associated with cylindrical wine and beer bottles of British 


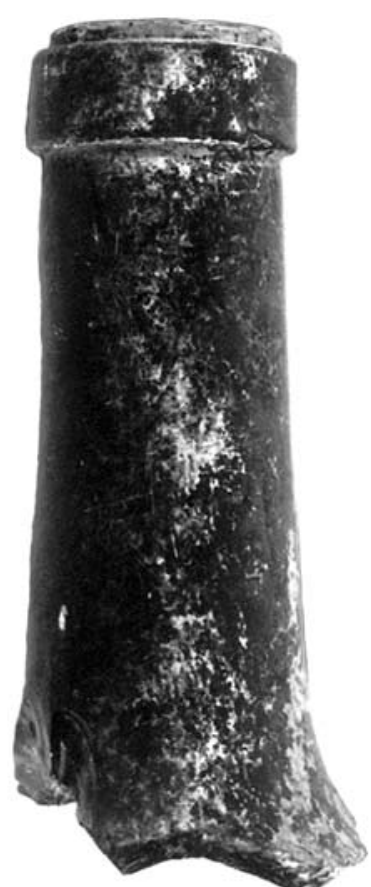

a

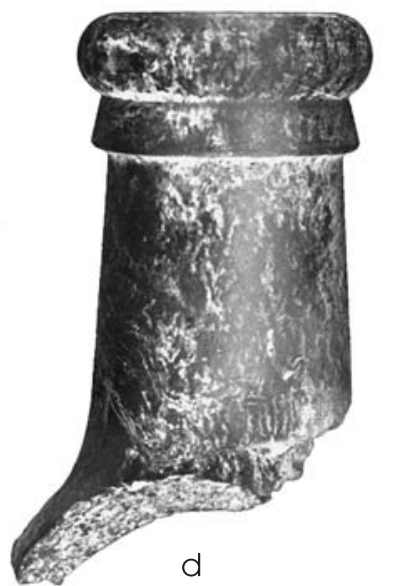

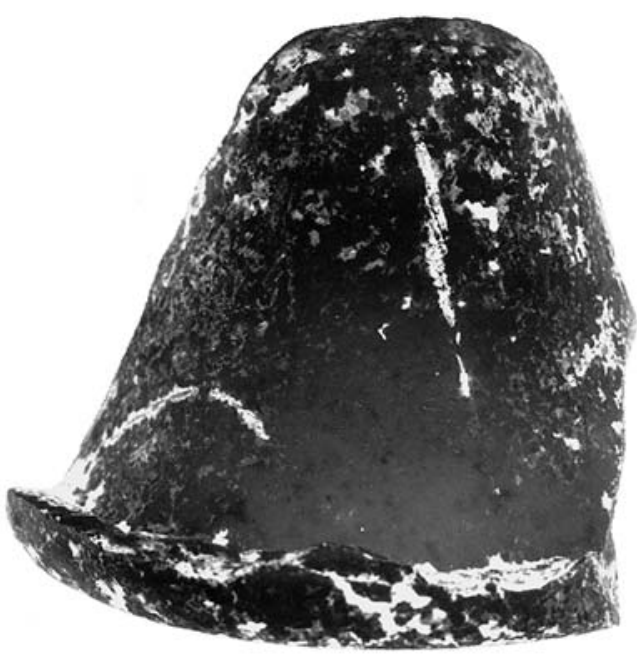

b

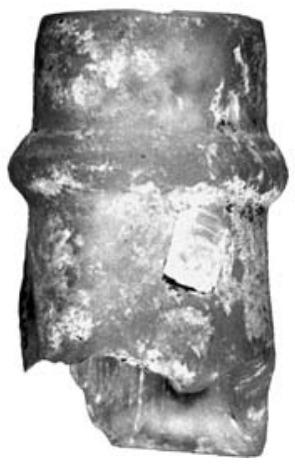

e

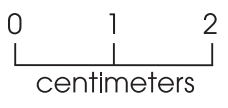

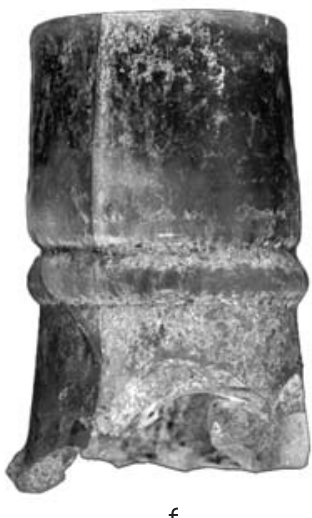

f

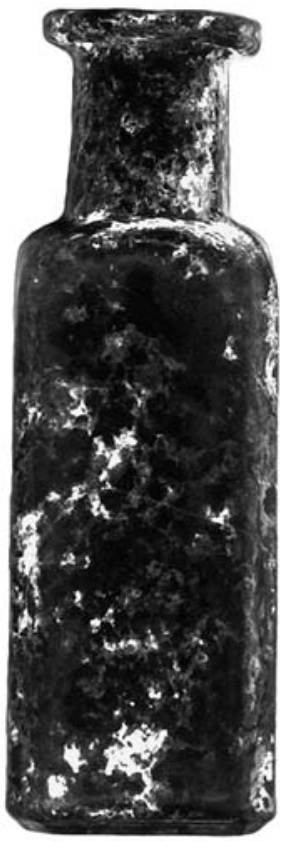

C

Figure 25. Container glass. (a) Champagne finish; (b) champagne pushup; (c) whole proprietary medicine bottle; (d) double-bead finish; (e) straight finish with ball neck; (f) patent finish; (g) brandy finish.

manufacture (Jones 1993:33). Diagnostic elements consisting of a finish (Figure 25a) and a base pushup (Figure 25b) were recovered in units E588+05/N130 and E587+00/N160, respectively. The finish has a wide, flat, applied string rim that was formed with a finishing tool.
The lip has been fire polished. This style of finish is called a champagne finish and typically was used on champagne bottles. It also sometimes was used for wine bottles, however, and it was common for these types of bottles to be kept and reused (Jones 1986:14). The base has a rounded 
heel with a conical pushup and portion of a mamelon. This type of base pushup also is associated commonly with champagne bottles (Jones and Sullivan 1989:87). Bottles of this type are of pre-1850 manufacture (Jones 1986:5), but its presence in this assemblage most likely is due to curation of the bottle, either for the sake of its contents or for reuse of the bottle.

One whole bottle was recovered from unit E588+05/N135 (Figure 25c). It is made of brown glass and measures $31 / 2$ inches tall. It is square in cross section with chamfered corners, and it has a wide prescription lip. The size, shape, and glass color make it consistent with a bottle type typically used for medicine, most probably of the proprietary variety.

The medical field at the turn of the century was still developing, and people sought relief for a wide range of physical and mental ailments from commonly available medicines. Two groups of drugs were available. The first were proprietary or patent medicines that could be purchased from traveling peddlers, local stores, and by catalog. Production of these concoctions was not regulated until passage of the Pure Food and Drug Act in January 1907. Proprietary medicines often contained large quantities of alcohol, opiates, or ingredients with no medicinal value at all. The second type of medicine available were ethical or prescribed medicines that often were associated with pharmacies, apothecaries, or druggists, who commonly packaged their medicines in bottles embossed with the establishment's name (Munsey 1970:174). Although medicinal preparations could be packaged in many different kinds of containers, liquids often were sold in bottles with paper and/or embossed labels. The period of ca. 1850 to 1907 was a peak time for the use of proprietary and ethical medicines in embossed label bottles (Fike 1987:3). The whole bottle recovered from the Rubin Hancock farmstead most likely had an entirely paper label.

Although sherds from embossed label bottles were recovered at 41TV875, most are too fragmented to identify to specific product. The one exception consists of 12 aqua glass sherds recovered from unit E588+05/N130. The fragmentary embossed label reads "...UMF.../ ...EMICA..." The full embossed label would have read "RUMFORD / CHEMICAL WORKS."
The product contained in the bottle was called "acid phosphate tonic and nerve food." The product was patented in 1868, produced in Rhode Island, and designed for making a healthy "lemonade" (Fike 1987:48). Although the term phosphate has other technical meanings, in this period it also was a slang word that meant a drink made with carbonated water and flavor, the earliest form of soda, which originally was believed to have healthy benefits.

Patent and proprietary medicines, as well as many other products such as shoe polish, blueing, flavorings, etc., were packaged in glass bottles with a variety of different finishes, such as the examples recovered at the Rubin Hancock farmstead. In addition to the examples discussed above, other finish types represented include the double-bead finish (Figure 25d), a straight finish with a ball neck (Figure 25e), a patent finish (Figure 25f), and a brandy finish (Figure 25g). As the name indicates, brandy finishes were used on brandy and other liquor bottles.

Bottles with these types of finishes and small mouths most commonly were sealed with corks, sometimes in combination with wire, a foil capsule, or wax to cover the cork and improve the seal. It was common in the late nineteenth and early twentieth centuries for patent or proprietary medicine bottles sealed with corks to be sold with a small, single-use cork ring. The cork ring could remove the stopper and then serve as a handle (Jones and Sullivan 1989:149-150). Such a cork ring was recovered from unit E588+05/N145.

\section{METAL}

The primary category into which metal artifacts from 41 TV 875 are classified is tin can fragments, of which there are 2,069 specimens. This is the largest category of artifacts in the assemblage.

\section{Tin Cans}

Most of the tin cans are represented by body fragments, which are almost entirely nondiagnostic. However, portions of can ends and side seams are present, thus indicating the variety of can types and associated products utilized at the Rubin Hancock farmstead.

At least five different can types are 
represented: hole-in-cap cans, key-wind cans, spice cans, embossed cans, and sanitary cans. Each type is discussed below.

Hole-in-cap cans represent a manufacturing technique used from ca. 1810 to ca. 1930 (Rock 1987:12). A well-preserved example was recovered from unit E587+80/N100. This specimen is cylindrical in shape with a filler hole (ca. 11/2 inches in diameter) at one end. Once the can was filled with food, a cap with a small center vent hole was placed over the filler hole and soldered in place. The entire can and its contents then would have been heated, and once the excess moisture and air were expelled, the vent hole would have been sealed with a drop of solder (Rock 1987:19). The period from the 1860 s to the 1900 s saw a boom in the canning of all varieties of fruits and vegetables in hole-in-cap cans (Rock 1987:48). This specimen has an overall diameter of $33 / 8$ inches, which is consistent with a "No. 2" size, and it would have been $49 / 16$ inches in height. Such cans typically were used for canned foods including baked beans, beans (string, white, lima, and kidney), corn, mixed vegetables, soup, okra, tomatoes, peas, spinach, succotash, blackberries, blueberries, cherries, gooseberries, peaches, pears, pineapple, plums, raspberries, strawberries, herring roe, and oysters (Rock 1987:92-96). Considering the limitations of food preservation methods in this period, especially in a hot climate, the availability of such a wide variety of stable canned foodstuffs would have been a great advantage.

The remains of key-wind cans are represented by both can fragments and a can key. A corner portion of a flat, rectangular-style key-wind can was recovered from unit E587+80/ N100. This type of key-opening, nonreclosable can was invented in 1866 (Rock 1987:69). This particular example is of the kind where the entire top panel of the can tears out. The most common contents for this can were sardines, which were packed mostly in California (Rock 1987:58-59). Other products packed in this sort of can include large hams, poultry, and processed meats. This can type was favored for these foods because they could be removed from the packaging in one piece (Rock 1987:69).

A variation on the key-wind can is the type opened with a key wind strip that removes a scored strip between the body of the can and its lid (Rock 1987:107). A small can key recovered from unit E588+05/N145 would have been used on a key wind strip. Although the technology was developed in the mid-1860s, it was not used widely until its adoption by the meat packing industry in Chicago in the 1890s. The Edwin Norton company developed a tapered tin with a key wind strip in 1895 for meat products such as corned beef, fresh beef, roast beef, beef tongue, lunch tongue, whole ox tongue, and boiled ham. The can was somewhat problematic because once opened it could not be reclosed (Rock 1987:74, 107). Reclosable key opening cans were developed ca. 1910 and were used primarily for nuts, candy, coffee, shortening and dried milk (Rock 1987:70).

The remains of one spice can were recovered from unit E587+65/N120. It is equipped with a dredge top to facilitate its use as a dispenser. Little information is available about the development of spice cans or their recovery on archeological sites. Rock (1987:74) notes that spice cans were available in a wide range of sizes and shapes and were used primarily for seasonings. Elsewhere, Rock (1984:110) states that logging camp sites often are marked by large-capacity tin cans, evaporated milk cans, and condiment tins, which perhaps would include spice cans.

One tin can top with an embossed label was recovered from unit E587+90/N125. It measures $2^{3 / 4}$ inches in diameter. A shallow groove runs across the middle of the top, and on either end are the soldered remains of what appear to be a bail-type/wire handle or opening device. An exact morphological match for this end type or method of manufacture has not been located in the literature on tin cans. However, the embossed label does provide important information. Arching around the upper circumference, the label reads "SCREW TO LEFT." Underneath that, in a series of three lines of text above the handle groove, it continues with "PAT'D / JAN. 31, '63 / MAR. 4, '73." Underneath the handle groove are two lines of text which read "DEC. 7, 1880 / MADE BY," and arching underneath, "NORTON BROS CHICAGO." Based on the information provided on the lid itself, this was some sort of screw-top can probably designed to be reclosable and reusable. Its contents are unknown, but it was probably a product like coffee or baking powder that was intended for consumption over a period of time and that would not spoil readily once 
the can was opened. The manufacturer was Norton Brothers of Chicago. Based on their patent dates, they had an established history in the canning business which had started in the United States in the 1840s (Busch 1981:96). Their initial patent date of 1863 for this design suggests that it probably was spurred by the Civil War, since food rations in cans were heavily utilized. The reliance on canned food in that period firmly established it as a safe and reliable food source for the civilian population after the war and beyond. In 1883, Norton Brothers went on to introduce a fully mechanized can manufacturing process that allowed them to produce 2,500 cans per hour (Busch 1981:97).

The most common can type represented in the Hancock assemblage is the sanitary can. It was invented in 1898, and its major technical innovation was the double-folded seam, thus eliminating the use of solder to seal the can. This fully automated process could manufacture 25,000 cans a day. The use of the sanitary can by food packers grew during the early part of the twentieth century, and it has become the standard form of tin can used today (Rock 1987:22).

\section{Other Metal Artifacts}

Three percent of the total assemblage is represented by miscellaneous metal artifacts $(n=258)$. A few of these items are identifiable, such as the artifacts discussed below. However, the bulk of this category consists of jar and bottle lids and items such as fragmentary straps, bars, and rods that are unidentifiable to more-specific functional categories.

Among the moreinformative artifacts in this class are metal container closures and utensils, which provide additional hints about family foodways and consumption patterns at the Hancock farmstead. A metal seal; (c) fork.
Hutchinson stopper (Figure 26a) from unit E588+10/N165 actually provides indirect information about the glass assemblage that was not observable directly. Hutchinson stoppers were used as closures for glass soda water bottles. As innovations were made in the closure types used for carbonated water, bottle types changed as well. The year 1879 saw the patented innovation of the Hutchinson's Patent Spring Soda Bottle Stopper. The closure consisted of a looped wire with a rubber gasket on the end. After filling the bottle, the spring stopper would be pulled up into the short neck of the bottle so that the rubber gasket formed a seal inside against the base of the neck. The force of the carbonation kept the stopper in place. When sealed, the tip of the wire loop protruded beyond the lip of the bottle, and hitting the top of the wire loop opened the bottle. Hutchinston stoppers typically were reused until the rubber gasket wore out (Jones and Sullivan 1989:162). Hutchinson stoppers were

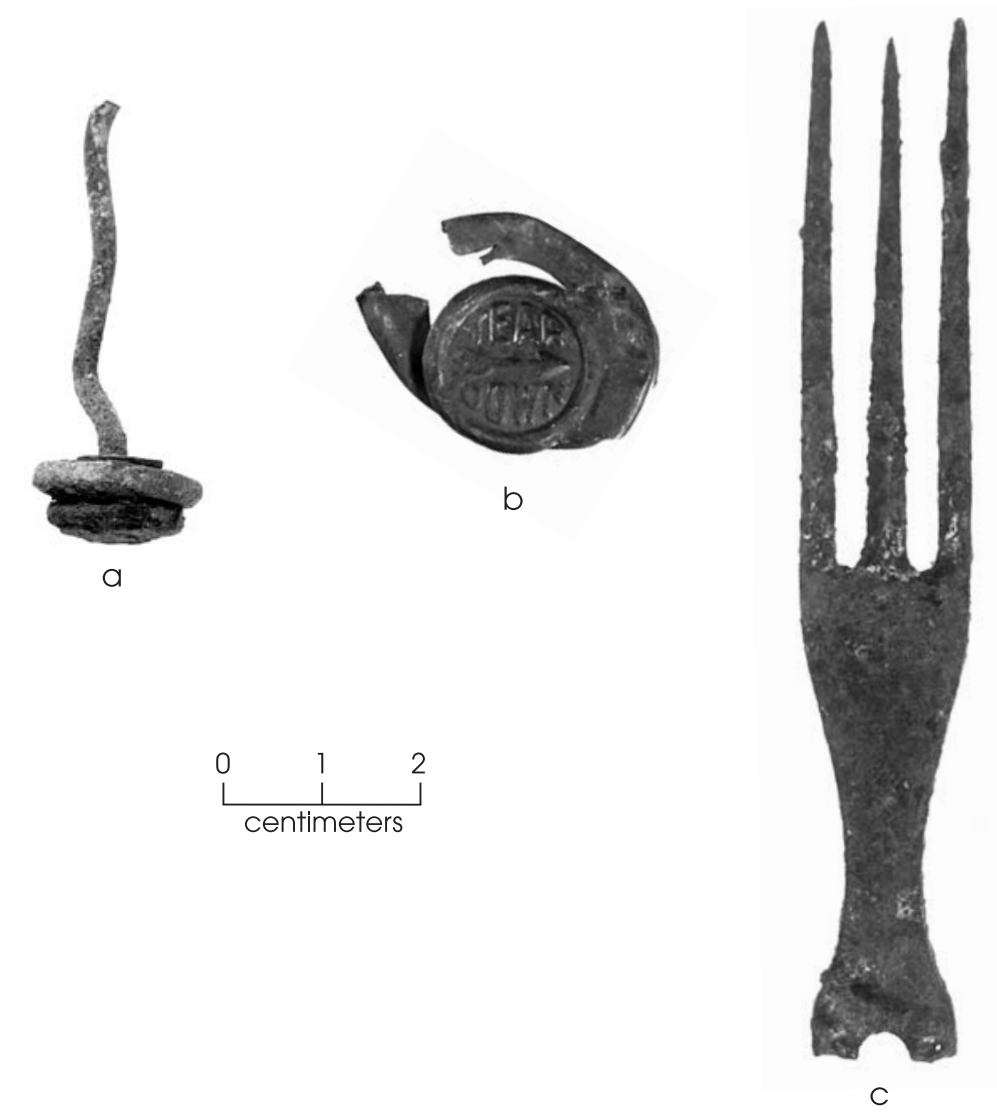

Figure 26. Metal closures and utensils. (a) Hutchinson stopper; (b) Goldy 
popular in their time, but they were not used later than the 1920s when they were deemed unsanitary and their use was restricted (Munsey 1970:105).

Another kind of metal closure for glass bottles is the Goldy seal (Figure 26b). Three such seals were recovered, one each from units E587+75/N140, E588+00/N140, and E588+05/ $\mathrm{N} 150$. The Goldy seal is a type of aluminum tearoff band cap, as is clearly specified in the directions on the top of the cap itself. The initial date of use on bottles was 1897 (Bender 1986:34). Alseco Seals of New Kensington, Pennsylvania, manufactured the Goldy seal. Although they also were manufactured for wide-mouthed containers, only bottle-sized seals were recovered from 41TV875. They typically were used on condiment bottles such as ketchup as well as other foods and medicines.

As a complement to the foodways-related artifacts made of ceramics, glass, and metal, a brief mention is made here of the related utensils. A small group ( $\mathrm{n}=5)$ of interesting utensils was recovered from the Hancock farmstead, including an especially good example of a three-tine fork from unit E586+60/N100 (Figure 26c). Both eating utensils and cooking utensils were recovered. Eating utensils include two three-tine forks and a tang from an unknown eating utensil. All three of these utensils are metal with handle tangs that would have had bone or wood plates fastened to them with pins. The 1897 Sears, Roebuck \& Co. catalog offered sets of six knives and six forks with this same style of handle starting at $\$ 0.40$ a set (Israel 1968:107). The cooking utensils include the blade from a large knife and an enameled tin cooking utensil handle. The mass production of affordable enameled tin cookware in every imaginable form began in the 1870 s (Vogelzang and Welch 1981:6). Other examples of enameled tin wares in the Hancock assemblage include a coffee pot lid and strainer, a pot/pan handle, and a washtub.

\section{HOUSEHOLD FURNISHINGS}

Eighty-three artifacts are in the category of household furnishings. These are primarily items that represent the furniture and accessories, both practical and decorative, that were used by the Hancock family in their home. For the most part, these items were durable goods and not disposable ones. Artifacts such as these give insight as to the interior of the house and its contents.

The largest group of artifacts within the household furnishings category is kerosene lamp chimney glass $(\mathrm{n}=25)$. An informant reported that electricity did not come to the area until the 1940s (Robinson 1987), which probably means that this house was never electrified. Therefore, the use of kerosene lamps for illumination would have been necessary for the Hancocks as well as the rest of the community.

Three different kinds of finishes for lamp chimneys were recovered, all of which are crimped varieties (Figure 27a). One older example (Figure 27a, left) is made of lead glass and has a hand-crimped finished. Two later examples are solarized glass and were made with a crimping machine. The "pie crust" edge (Figure 27a, right) was made with a machine patented in 1877 (Woodhead et al. 1984:62).

Part of a kerosene lamp base was recovered as well. It is represented by three solarized glass sherds, all of which crossmend, from units E587+80/N100, E588+05/N140, and E588+30/ N130. The base has a pressed design on the interior that can be seen through the smooth exterior. The pattern is called "Carlisle" and was manufactured in both hand and stand lamp varieties. Not enough of the specimen from 41TV875 survives to determine which type it was. The "Carlisle" pattern lamp was manufactured after 1880 (Thuro 1976:263).

Another accessory present in the Hancock household was a clock, of which three gears and a clock winding key were recovered (Figure 27b, c). Four different types of clocks were available in this period: the tall case clock, the mantel clock, the shelf clock, and the wall clock. It is unknown which one of these the parts recovered from the farmstead represents. American manufacturers produced large numbers of clocks in the second half of the nineteenth century, the most common of which was the wood case shelf clock (Mace 1991:118).

In terms of larger pieces of furniture, two can be identified from hardware, others from archival sources. An iron caster and socket set was recovered from unit E588+05/N135 (Figure 27d). A matching furniture caster without socket was recovered from unit E588+30/N130. Furniture casters were manufactured in different sizes and socket styles depending on 

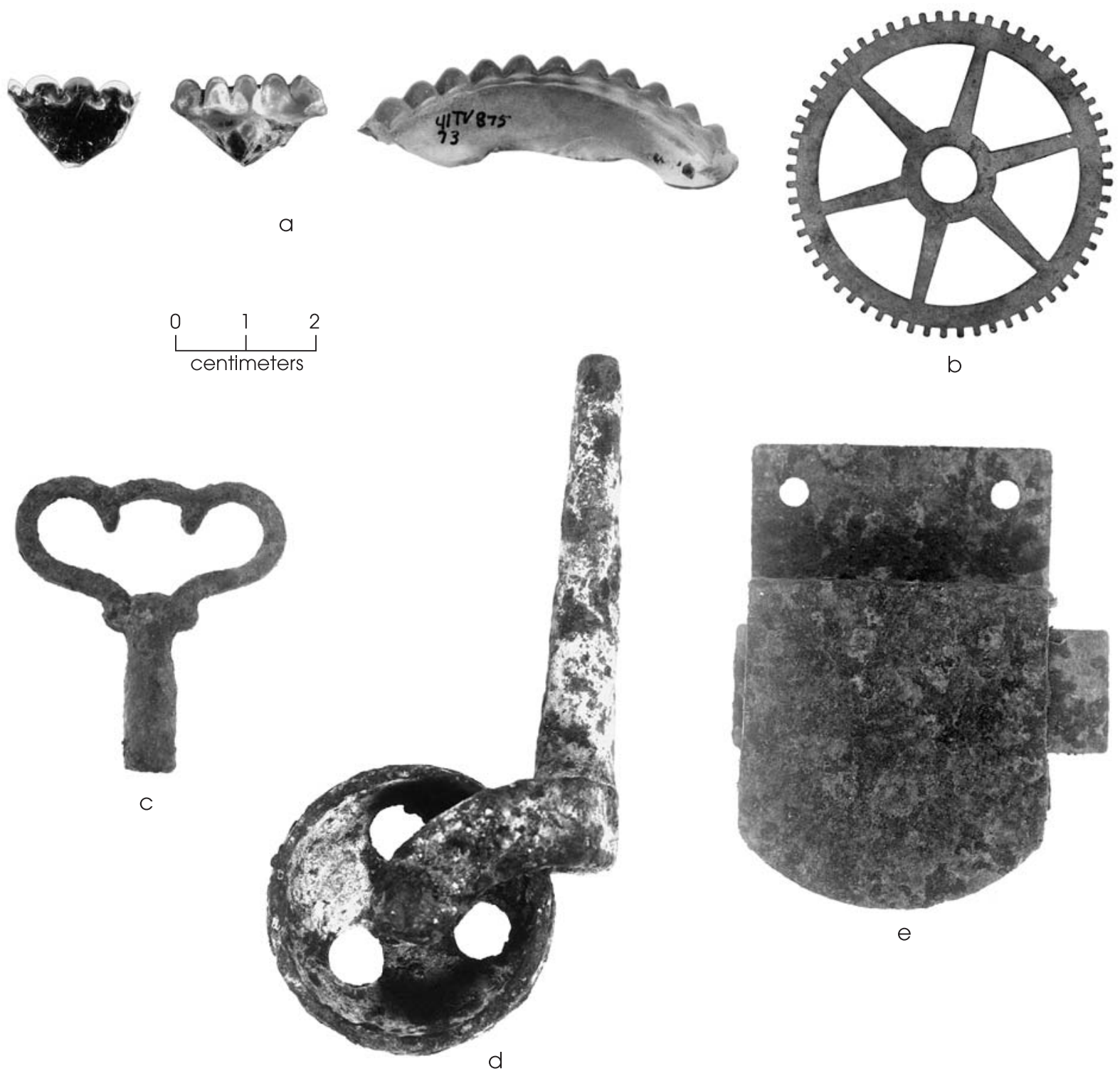

$\mathrm{b}$

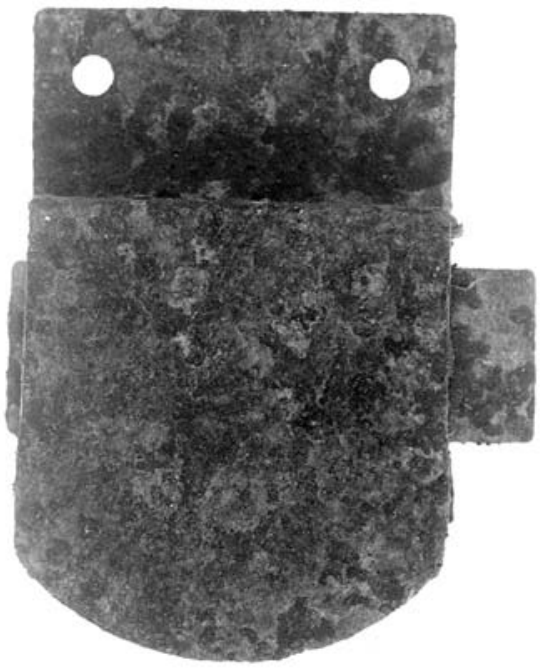

e

Figure 27. Household furnishings. (a) Lamp chimney finishes; (b) clock gear; (c) clock key; (d) bed caster; (e) trunk lock.

the type of furniture for which it was intended. This particular kind would have been used with a wooden bed frame (Russell and Erwin Manufacturing Company 1865:159). Metal beds were not common until the twentieth century (Mace 1991:125).

A second piece of furniture hardware was recovered from unit E588+35/N140. It is a lock of the type used on a trunk (Figure 27e). This is the upper portion of the lock that would have been affixed to the lid and would have closed onto a corresponding plate with keyhole on the body of the trunk (Russell and Erwin Manufacturing Company 1865:135). Trunks were used not only as luggage, but also as storage space, which most likely was the case at the Hancock house. A variety of different sizes and styles were manufactured in large quantities from the 1870s into the twentieth century, and all featured at least one lock (Mace 1991:146). Such a secure object could have served as a repository for valuables in the 
Hancock house, or simply as storage for bulky items such as blankets or linens.

A variety of other household furnishings are in the assemblage. They include upholstery/ furniture tacks $(n=10)$, latch parts $(n=2)$, cast iron stove fragments ( $\mathrm{n}=15$ ), cast iron skillet/ pot fragments $(\mathrm{n}=4)$, a kettle handle, metal washtub fragments $(\mathrm{n}=3)$, a picture hanger, and the utensils and enameled tin kitchenware discussed previously. Two possible electrical parts also are included; they most likely represent car parts.

Rubin's 1916 will provides a few additional clues as to furnishings contained in the Hancock house. In making provisions to divide items between his three daughters, he gave "one bureau with glass attached and having three drawers" to Mattie, "one large warderobe [sic] with double doors" to Susie, and "the rest of the household and kitchen furniture" to Fannie. Based on the combined archeological and archival information, the Hancock family appears to have created for themselves a modestly prosperous home.

\section{ARCHITECTURAL ARTIFACTS}

A total of 2,696 specimens are in the architectural artifacts group. Of that number, nails dominate $(\mathrm{n}=2,218)$. Both cut and wire nails were recovered, with cut nails being over twice as numerous $(\mathrm{n}=1,532)$ as wire nails $(\mathrm{n}=$ 686). The large number of nails correlates with the presence of frame buildings on the property. The ratio of cut to wire nails indicates that the original construction of the house and any outbuildings utilized cut nails and that subsequent additions and repairs to structures were made using wire nails, although there could have been mixed use as well.

Another large group of architectural artifacts is window glass sherds $(\mathrm{n}=419)$. The distribution of window glass was analyzed for this site (see Chapter 6), but no other specific analyses were done. Measuring window glass thickness for use as a chronological tool was not undertaken since the chronology of the site is well documented through other more-diagnostic artifacts and the archival evidence. The presence of window glass indicates that the house had several windows, which would have been typical for a turn-of-the-century house.

The remaining specimens in the architectural group $(n=59)$ consist of an assortment of items, including roofing tacks and nails, wood screws, a piece of lead pipe, a piece of milled lumber, mortar fragments, and a piece of clay tile. Also included are three pieces of door hardware. The first of these is a mortise lock from unit E587+55/N165 (Figure 28a). A mortise lock is one equipped with a protruding bolt that fit into a corresponding slot on the door frame, as in many modern doorknobs. This specific kind of lock is an "upright rim knob lock." The latch was designed to be reversible, and it could be installed either right- or left-handed. In a nineteenth-century hardware catalog (Russell and Erwin Manufacturing Company 1865:17), a matching example was sold "packed with escutcheon plates and screws." The escutcheon plate that fits this lock was recovered from unit E588+10/N155 (Figure 28b). For an additional cost, this lock kit could be purchased "with mineral knobs and jappaned [sic] mountings." The doorknob shaft would have fit through the square hole in the lock face. Although none of the mountings were recovered, a of set mineral knobs was recovered-one from unit E588+35/ N135 and one from unit E588+00/N140 (Figure 28c). This dark style "mineral" door knob actually was a ceramic consisting of two different colors of clay that were mottled to give an agate or marbled effect.

\section{PERSONAL BELONGINGS AND ATTIRE}

Artifacts in this category are items that primarily are considered to have been individual personal possessions. Although there is no way to know to what degree belongings were shared among family members, things like jewelry or clothing are typically utilized by one person at a time. This category is small, consisting of only 217 specimens.

\section{Activities}

Many of the personal belongings recovered correlate with specific activities that would have been carried out by various members of the family. Sewing is an activity in evidence at the site. A fragment of a possible sewing machine part was recovered, but it is likely that most of the Hancock needlework was done by hand. In addition to the buttons and clothing fasteners 


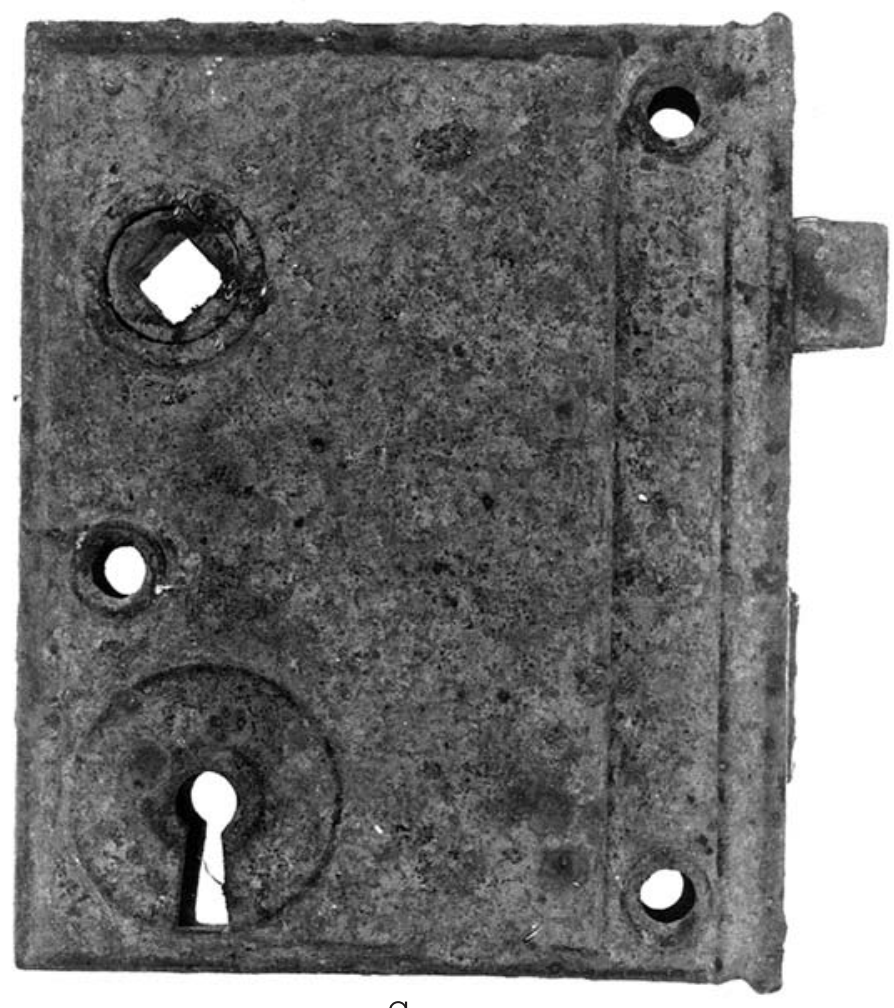

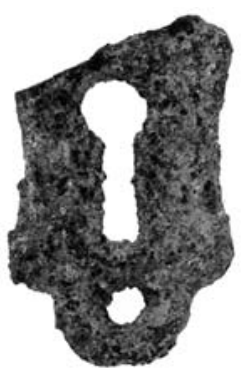

b

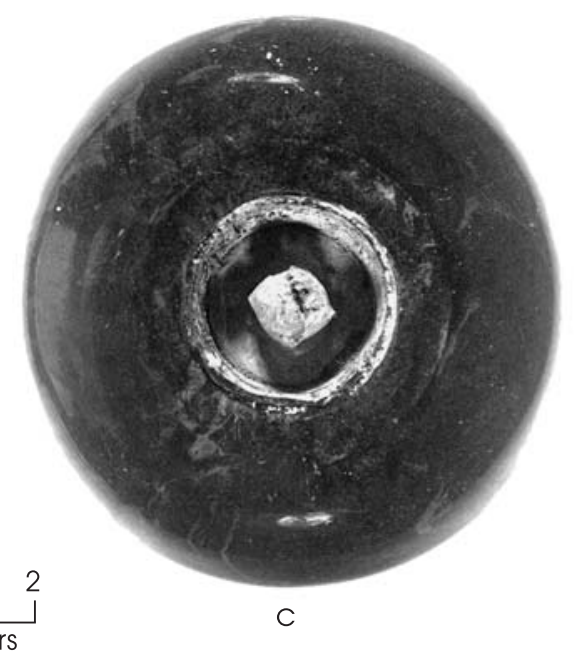

Figure 28. Architectural artifacts. (a) Upright rim knob lock; (b) escutcheon plate; (c) “mineral” door knob.

discussed below, sewing scissors are represented by 10 fragments representing at least two different pairs of scissors, including a largely intact example excavated from unit E588+00/ N140 (Figure 29a).

A single straight pin (Figure 29b) was recovered from unit E588+05/N140. It is not surprising that sewing artifacts were recovered from this domestic context. Throughout the nineteenth century, women of all sorts counted sewing, both plain and fancy, as one of many necessary household tasks. Farm wives would have been responsible for making everyday/ work clothes for the entire family, and most probably a set of "Sunday best." Linens, quilts, and other bed coverings also were commonly produced in the rural home. Some of those items were purely functional, whereas some featured fine needlework. Elizabeth Hancock would have had the sewing and mending for a family of seven to tend to on a year-round basis. As her four daughters grew, she would have taught them those skills, they would have learned to help with the family sewing, and they would have continued sewing for their own families once married.

As for Rubin, agricultural pursuits would have occupied most of his time. In addition to farming, Rubin probably hunted and fished to supplement the family diet with meat. A fishing reel part and 13 pieces of ammunition were recovered. This low number of firearms-related artifacts probably relates to the fact that Rubin would have hunted in undeveloped areas away from the house, thus spending his ammunition elsewhere.

Of the 13 pieces of ammunition recovered, four different types are represented: 12-gauge shotgun shell heads $(\mathrm{n}=5), .22$-caliber long cartridges $(n=4), .22$-caliber short cartridges 


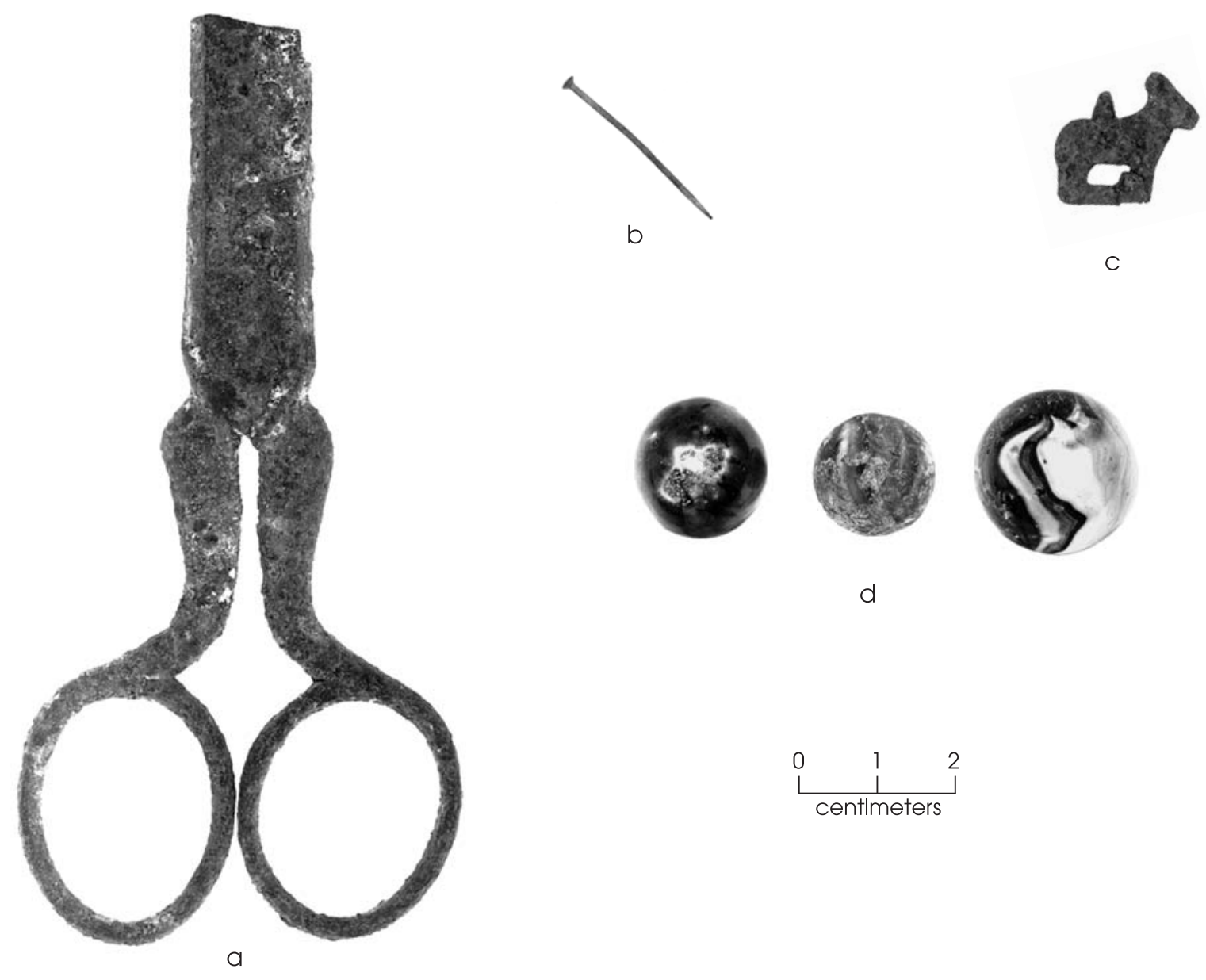

Figure 29. Activities-related artifacts. (a) Sewing scissors; (b) straight pin; (c) tobacco tin tag; (d) marbles.

( $\mathrm{n}=3$ ), and one 410-gauge shotgun shell head (Barnes 1993:394). Ten have identifiable headstamps.

Four brands of 12-gauge shotgun shells are present. "Repeater," "Nublack," and two examples of "Ranger" are all products of the Winchester Repeating Arms Company of New Haven, Connecticut. These brands were available from the late 1870s until the early 1900s (Vinson 1968:91). The U.S. Cartridge Company of Boston, Massachusetts, is represented by one brand, "Defiance." The U.S. Cartridge Company started in 1864, then sold to National Lead Co. in 1911, after which they continued to produce U.S. cartridges until the late 1920s. The "Defiance" brand is one of the later products (Vinson 1968:92, 93).

Two identified brands of .22-caliber long rim-fire cartridges are present. Both are from the Union Metallic Cartridge Company of Bridgeport, Connecticut. Both feature an impressed "U" headstamp, which was used after 1885 (Barber 1987:48). The second kind of headstamp is "Super X," which was made by the Western Cartridge Company of East Alton, Illinois, after 1927 (Barber 1987:86). This cartridge probably represents hunting or sport shooting at the site area after Rubin's death. The two .22-caliber short rim-fire cartridges are of the same brand with an impressed " $\mathrm{H}$ " within a circle headstamp. These cartridges also are products of the Winchester Repeating Arms Company; the company used this headstamp between ca. 1880s to 1895 (Barber 1987:55).

Very little direct evidence was recovered of how any of the Hancocks spent their leisure time. Certainly, activities shared with family, community, and church would have been 
important. Otherwise, it can be assumed that the Hancocks indulged in the simple pleasures common to the period. The recovery of three mule-shaped tobacco tin tags indicates that plug tobacco was a product used on the Hancock farm, probably by Rubin. The best example of this tag type was recovered from unit E588+35/ N150 (Figure 29c). It features the outline shape of a mule along with two small tabs, one at the top and one at the bottom, that would have been pressed into the face of the tobacco plug as a label. Although all examples from the site are completely rusted, originally they would have carried a painted label. Chewing tobacco was at its peak of popularity ca. 1890, and 19 different varieties of plug tobacco were available in the 1897 Sears, Roebuck and Company catalog (Boyd et al. 1994:181; Israel 1968:24).

While growing up, the Hancock children would have had their own share of work and play. Work probably consisted of schooling as well as chores. Since it is known that both Rubin and Elizabeth were illiterate, the artifacts related to writing probably belonged to their children. Those items include a paper clip, slate pencils $(n=3)$, and paper staples $(n=2)$.

In all likelihood, most of the forms of play would not have left archeological remains. Homemade toys fashioned from biodegradable materials, play with other children, and the entertainment value of a child's imagination do not leave physical traces. Although a small group $(n=7)$, some commercial toys were recovered, including porcelain doll fragments and marbles. In addition, single fragments of both a harmonica and a pocket knife could have contributed to the pastimes of any member of the Hancock family.

Three different types of decorated marbles have been identified (Figure 29d). Two handmade marbles were found in unit E588+20/ $\mathrm{N} 155$, and one machine-made marble came from unit E588+35/N140. The Bennington-type marble (Figure 29d, left) is made of clay and has a brown mottled glaze. Although named for the Bennington pottery in Vermont that produced brown mottled glazed wares, this type of marble was not produced exclusively at that location. The irregularity in the glaze is from the marble resting against another surface during firing. This type of marble was produced and available throughout the nineteenth century (Grist 1993:36; Randall 1979:7).
The handmade glass marble (Figure 29d, center) has a surface covered with impact marks, an indication of much use. It is a "transparent swirl" marble with a multicolored solid core of red, blue, white, green, yellow, and pink. Slight bulges are present at opposite sides of the sphere, indicating hand manufacture with a pontil. This type of marble was manufactured and available from ca. 1840 to ca. 1910 (Grist 1993:19; Randall 1979:7).

The machine-made marble (Figure $29 \mathrm{~d}$, right) also exhibits a number of surface impacts. It is a glass "slag" marble in brown and white (Grist 1993:63). Production of machine-made marbles began ca. 1910 and continues to the present (Randall 1979:7).

\section{Personal Adornment}

Personal attire in the form of clothing, shoes, accessories, and items related to grooming is a primary way in which people throughout time have communicated identity, social status, and group membership. Archeologically, these items and the ideas they represent usually are captured only by the recovery of hardware, fasteners, and small parts made of metal, glass, or ceramic. A varied assortment of artifacts are in this category. In addition to the artifacts discussed below, grooming items include a bone toothbrush head, a hairpin, and bone comb teeth $(\mathrm{n}=2)$.

Clothing fasteners and buckles are represented by 49 specimens that correspond to both female and male clothing items. Both corset steels and "corset clasps" were recovered, such as the example from unit E588+30/N155 (Figure 30a). From a modern perspective, fashionable women's undergarments during the nineteenth century were impractical at the very least. However, the Hancock women were required to perform a multitude of demanding household tasks as well as production of goods like butter and eggs as cash products, and they may not have had the luxury to be concerned with the fashion demands of the gentlewoman in their everyday lives. Still, late-Victorian society had certain parameters within which people were expected to behave. At the turn of the century, the constraints of acceptable female attire were becoming less rigid, but the standard was still that most of the body be covered from neck to wrist to ankle (Willett and Cunnington 


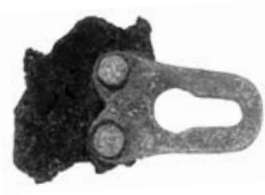

a

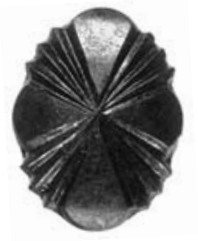

b

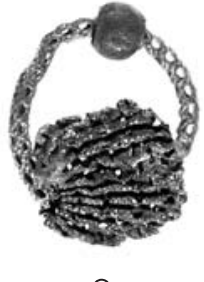

C
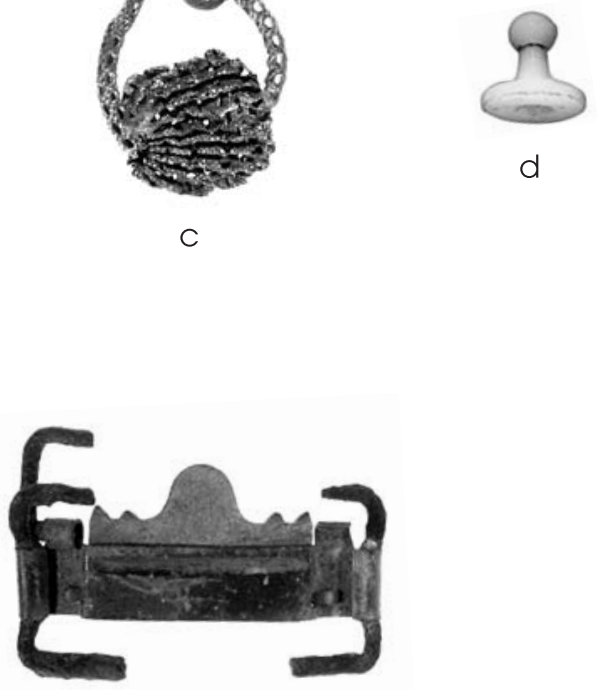

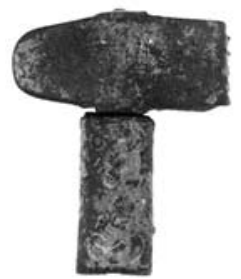

e
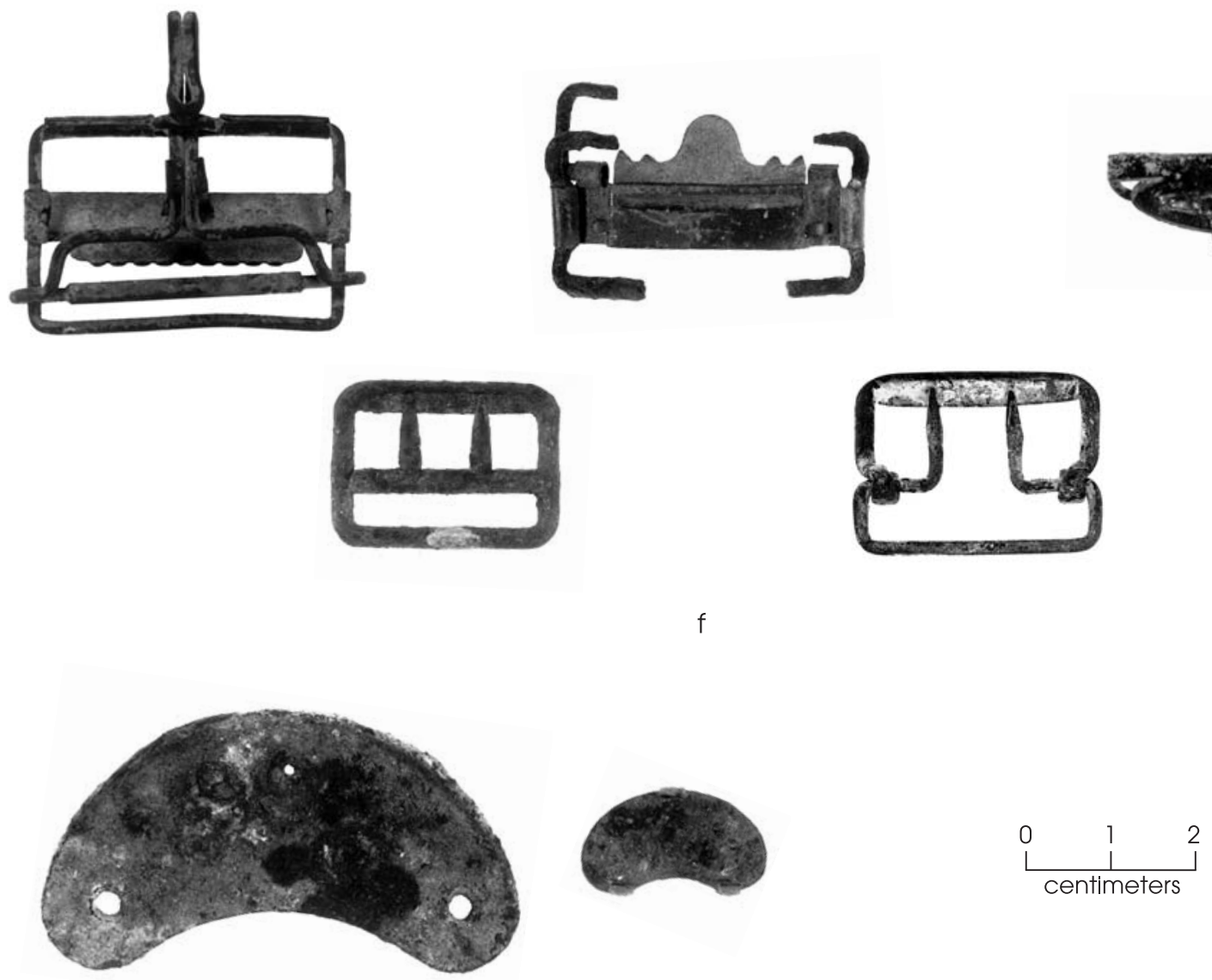

g

Figure 30. Personal adornment items. (a) Corset clasp; (b) black glass jewelry inset; (c) gold-plated pendant; (d) shirt stud; (e) Wizard cuff holder; (f) buckles; (g) shoe heel plates.

1992:194-195). Wearing a corset was part of the genteel female costume. In the 1890s, "it was a girl's ambition to have, at marriage, a waistmeasurement not exceeding the number of years of her age - and to marry before she was twenty-one" (Willett and Cunnington 1992:197198). It was exactly in this period when the Hancock's daughters all married. Although it is not known to what degree they followed the latest fashions, archeological evidence suggests that to some degree they conformed to societal norms. Photographs of Elizabeth, Mattie, and Martha Ann Hancock also indicate that they did strive to present themselves as well groomed and respectably dressed women of their times (see Figures 4, 7, and 8).

Two other artifacts offer insight as to how the Hancock women adorned themselves for 
dressy occasions, such as Sunday church services. Two pieces of jewelry were recovered. The first is a black pressed-glass jewelry inset from unit E588+05/N140. (Figure 30b). It is oval in shape and has a design of converging lines. It probably was set into a brooch pin or other similar type of jewelry. Black glass was a common substitute for the more expensive jet that was fashioned into jewelry and buttons. Black jewelry of either sort became generally popular in the period 1861 to 1890, spurred by Queen Victoria's period of mourning (Pool 1987:288). Both Elizabeth and Mattie are wearing black "mourning jewelry" lace pins in their photographs (see Figures 4 and 7).

The second piece of jewelry was recovered from unit E588+05/N135. It is a gold-plated filigree ball charm (Figure 30c). This type of pendant was found most commonly on ladies' vest chains and was entirely decorative. Vest chains were available in different styles, but they were almost always gold or gold plated (Israel 1968:410-413).

Men's attire during this period was somewhat less constrictive than women's, but what was deemed fashionable was no less codified. Class and status were delineated clearly by mode of dress. Again, as a farmer, the dictates of fashion probably were not one of Rubin Hancock's daily concerns. But some occasions would have called for finer apparel than that worn on a daily basis. Two artifacts recovered during excavations are associated with men's dress clothes: a shirt stud (Figure 30d) from unit E588+20/N155 and a cuff holder (Figure 30e) from unit E588+30/N155.

From about the late 1850s, buttons had been replaced on dress shirts by the use of studs (Willett and Cunnington 1992:138). They were used variably as fasteners on cuffs, collars, and shirt fronts. Studs were available in a wide range of styles and materials, from the most basic like the porcelain example illustrated, to the fanciest solid gold studs. As with women's fashions, by the 1890s men's wear was becoming more relaxed. It became acceptable to show much of one's shirt front, and for the first time the turned down "polo collar" so familiar today became acceptable (Willett and Cunnington 1992:188). It is on this type of exposed dress shirt front that a shirt stud would have been worn. Close inspection of the undated photograph of Rubin shows him wearing exactly this style of shirt with studs (see Figure 4), suggesting that the picture was taken sometime during the 1890 s.

Not visible in that photograph are the cuffs on Rubin's shirt. It is possible that he was wearing a pair of "Wizard Cuff Holders," one fragment of which was recovered during excavations. The cuff holder functioned like a cuff link by means of a clip on one end and spring clasp on the other. The device was patented in 1889 (Israel 1968:221).

Buckles and fasteners from everyday work clothes are much more prevalent in the assemblage and were recovered all across the site. A minimum of five different intact types are present (Figure 30f), and other fragmentary examples are present as well. Adjustable and slide buckles of different sizes and types were used widely on clothing at the turn of the century. Men's, women's, and children's clothing items such as garters, suspenders, hose supporters, belts, pants, vests, and overalls all utilized buckles. One innovative slide buckle design (on the far left in Figure 30f) is marked "PAT, JULY, 15, 1890."

Other hardware items associated with attire are two heel plates (Figure $30 \mathrm{~g}$ ). These metal plates were designed to "prevent boots and shoes from wearing off at the heels" (Israel 1968:208). Heel plates would have been an economical way to help prolong the usability of the family's shoes, which most likely had to be purchased locally or by catalog. The larger example is a size designed for men's shoes and would have been affixed to the heel with small nails. The smaller example would have been for children's or women's shoes. Three prongs protruding from the heel plate affixed it to the heel. Including the two heel plates, 55 specimens from shoes were recovered, including recognizable leather shoe parts and metal eye grommets.

Related to the attire category are umbrellas and parasols. Four umbrella/parasol ribs were recovered. Whereas umbrellas are practical items for inclement weather, parasols are fashion accessories. Not enough of these specimens survived to indicate which forms were present at the Hancock farm.

\section{Buttons}

Buttons were by far the most common 
clothing fastener used at the turn of the century. Fifty-two buttons were recovered from the site. Materials used include shell, porcelain, metal, glass, and composition. Buttons made from shells commonly are called "pearl" or "motherof-pearl" buttons, depending on the type of shell used. Shell buttons were produced in an almost limitless range of sizes and styles. The Hancock assemblage contains 15 shell buttons, representing two commonly seen forms. Both illustrated examples were recovered from unit E588+30/N155. One is a two-hole sew-through button, and the other a four-hole sew-through button (Figure 31a, left and right respectively). These simple buttons were utilized heavily on underclothing, but the late nineteenth and early twentieth centuries saw a great increase in their use on other items as well. This period was the first time in which the ready-made clothing industry saw growing success, particularly selling garments through mail-order catalogs. Fashions also were changing in such a way that more buttons were being used. Finally, the protection of American markets by the McKinley Tariff in 1890 allowed the domestic development of the shell button industry (Claassen 1994:66-67).

Metal has been a popular material for buttons for a long time because of its durability. Sixteen metal buttons were recovered at the Rubin Hancock farm. Although they vary in type, the brass stud-style overall/jeans rivet is the most common. Rivets serve the same purpose as buttons on jeans and workpants and are used in conjunction with hooks and slide buckles on overalls. Three distinctive metal buttons were recognized. One from unit E588+20/N155 has decoration consisting of an elaborate series of concentric circles (Figure 31b, left). The second, from unit E588+05/ N140, has an embossed label on its face (Figure $31 \mathrm{~b}$, center). The one line of text that arches around the top reads "H. \& H.'s," and the second that arches around the bottom reads "BULL DOGS." The two lines are separated from one another on each side by a single dot. The background features fine crosshatching. The third button, from unit E588+35/N150, is slightly different from a rivet stud. The face has two faint lines of text in script that appears to read "Harris Patent" (Figure 31b, right). The back of the button is fashioned somewhat like a snap with a corresponding stud and two washers by which it was affixed to the fabric. This is a "hand snap"
Figure 31. Buttons and button hook. (a) Shell; (b) metal; (c) porcelain; (d) glass; (e) button hook. 
type button for which no sewing was required. Advertisement of this product touted that "by the use of these buttons the traveling man, the farmer, the laborer, the mechanic, the growing boy and his father, of any profession, can instantly replace his missing buttons" (Israel 1968:320). Perhaps Rubin resorted to using hand snap buttons once he became a widower and his daughters had moved away. The production, advertisement, and use of a product like this are an indication that sewing fell almost exclusively within the realm of women's work. These metal rivets and buttons represent the everyday work clothes-jeans, overalls, work shirts-that would have been the common attire for the Hancock family on the farm, especially Rubin.

Porcelain buttons are equally well represented ( $\mathrm{n}=15)$. Commonly called "china" buttons, plain white sew-through porcelain buttons were often utilitarian. However, three decorated examples were recovered. The "pie crust" type (Figure 31c, left) is a four-hole sewthrough button with radiating lines around the circumference. It was recovered from unit E588+20/N135. A single fragment of a four-hole sew-through calico button (Figure 31c, center) was recovered from unit E588+15/N145. It has a small repeating floral design in brown. Calico buttons were decorated by means of transfer printing in the same manner of ceramic tablewares (Pool 1987:281). The third porcelain button (Figure 31c), was recovered from unit E588+15/N155. It is fragmentary, has a metal loop shank attachment on the back, and is made of bisque (unglazed) white porcelain. The button has a conical shape but is otherwise undecorated. This button probably was made for dressier women's clothing.

The fanciest buttons recovered are those made of glass $(n=5)$. Glass was not the preferred material for buttons because of its fragility. However, glass buttons were imported into the United States during the nineteenth century, primarily from Czechoslovakia or Bohemia (Pool 1987:283). Three of the glass buttons in the assemblage are common black glass "mourning" style buttons. The other two are more uncommon types (Figure 31d). Front and back views of one fragmentary example (Figure 31d, left and center) show that it was blown into a mold. It has a floret-shaped face made of clear glass, with a center of turquoise glass. A metal loop shank is inserted in the back. It came from unit E588+35/N150. The other example, from unit E588+00/N140, is a small whole button made of lead glass (Figure 31d, right). It was made in a mold and has a "self shank" attachment. That is, the sew-through loop on the back is part of the button itself. The face is convex and has 18 facets. Elizabeth Hancock's dress front, as shown in Figure 4, has buttons that appear to be of a very similar type to this excavated example.

A button hook was recovered from unit E588+30/N155 (Figure 31e). Because of the quantity of buttons used to fasten both clothes and shoes, button hooks were used to make the task faster and easier. The hook was passed through the hole or loop and then used to pull the button into place (Mace 1991:128). A button hook commonly was included as part of a dresser or toilet set along with brushes, combs, hand mirrors, etc., all of which could have handles made of mother-of-pearl, ivory, celluloid, or silver plate. However, this example is a much more utilitarian specimen. It is made entirely of ferrous metal with a simple looped handle. Although highly corroded, close inspection of the flattened part of the handle reveals that it was embossed with an apparent advertising label. Most of the embossing is no longer legible, with the exception of a portion that reads "...AUSTIN TEX." Most probably, this item was purchased at a store in Austin and the embossed label advertised that establishment. This artifact makes a direct connection between the Hancock family and the businesses within Austin proper. Although Austin was farther from the Hancock farm than the stores in the small surrounding towns, Austin would have offered a wider selection of goods. In all likelihood, shopping trips into Austin were done periodically.

\section{FARMSTEAD ARTIFACTS}

Artifacts in this category consist of items related to the practices of farming and any support activities that would have been confined primarily to areas such as the yard, fields, or outbuildings. This category is subdivided into three groups of artifacts: fence staples $(n=74)$, wire fragments $(\mathrm{n}=519)$, and miscellaneous farmstead artifacts $(n=60)$, for a total artifact count of 653 . 


\section{Fence Staples}

The most obvious purpose for fence staples is in the construction of barbed wire fences. As fasteners, fence staples actually were manufactured in four different lengths ranging from $3 / 4$ inch to $1 \frac{1}{2}$ inches. The smaller examples were intended for woven fencing, while the larger examples were intended for barbed or smooth wire fencing (Israel 1968:43). The presence of nails in some fence posts at the site indicates that an expedient mix of fasteners was used in fence and pen construction. It also is possible that fencing staples were used for tasks other than fence construction around the farmstead.

\section{Wire Fragments}

Wire fragments of every variety are classified in this category. Types recovered include plain/smooth wire of varying gauges, barbed wire, livestock wire, and wire obviously utilized for construction or repair tasks. Of the farmstead artifacts, wire fragments constitute the largest portion (79 percent). This large proportion indicates the general usefulness and versatility of all types of wire on a farm.

\section{Miscellaneous Farmstead Artifacts}

Sixty artifacts are classed as miscellaneous farmstead artifacts. They include large

fasteners such as spikes, nuts, bolts, etc., which related to farm machinery, wagons, or carriages.
All harness, tack, and livestock equipment is included, such as harness buckles, horseshoes, and horseshoe nails. Most interesting is a wiffletree center clip recovered from unit $\mathrm{E} 588+35 / \mathrm{N} 150$. The wiffletree is part of the harness gear that keeps a pair of horses abreast while pulling a plow or wagon. This metal object would have been affixed to the center of the yokelike wiffletree, acting as an attachment point for the rest of the harness gear (Spivey 1979:23).

\section{FAUNAL}

The faunal assemblage consists of 508 animal bones, with both whole and fragmentary specimens present. Bones from the dog burial constitute 17 percent of the faunal assemblage $(n=87)$. Although the assemblage was not the subject of a formal analysis, the remainder of the collection probably represents animal bones associated with historic foodways of the Hancock family.

\section{UNIDENTIFIED/OTHER}

This category represents 1.4 percent of the total assemblage $(n=125)$. These are items for which no functional identification could be determined (such as wood fragments), or items that do not fit well into the functional categories as established (such as limestone fragments). For the most part, because many of these objects are unidentified, they provide little in the way of interpretive value. 



\section{THE RUBIN HANCOCK FARMSTEAD, CA. 1880-1916}

\section{SITE STRUCTURE}

Two primary forms of archeological data can contribute to an understanding of the layout of the Rubin Hancock farmstead: features and artifacts. The two data sets provide different kinds of information, with features chiefly reflecting the built environment and artifact patterning addressing the use of space and activity areas.

\section{The Feature Evidence}

Although individually some of the features have limited interpretive potential, taken as a group they provide a reasonably good understanding of how the core area of the Hancock farmstead might have been arranged and used (Figure 32). The house foundation is of central importance to understanding the layout of the farmstead. Archeological excavation revealed that the building was roughly $30 \mathrm{ft}$ square, making for approximately $900 \mathrm{ft}^{2}$ in which Rubin and Elizabeth lived and raised their four children, joined at times by Rubin's daughter (by Rosetta Williams) Martha Ann, Rubin and Elizabeth's oldest child, Melvina, apparently was married and no longer part of the household by the time they moved to 41 TV875. There is no indication that the house was more than one story tall.

Based on the relative arrangement of the house, the yard and garden, the fence lines, and the two old roads, the front of the house most likely faced grid east (southeast). That orientation would have placed the front of the house facing the main access road, whereas the yard, garden, and fences would have been to the sides and rear.
Some details about the house interior can be gleaned from a variety of sources. The fireplace was centered on the north wall of the building. This suggests that that part of the house was a primary living area. The actual plan of rooms within the house is not known, but it is possible to propose some possible arrangements of space. There is evidence for only one fireplace, and because at the turn of the century cooking normally was done with cast iron stoves, it is likely that the fireplace was in a main living area, not a kitchen. The house definitely had a specific area utilized as a kitchen. Rubin Hancock himself mentioned "kitchen furniture" separate from "household furniture" in his will. Also, cast iron fragments found in the excavations include pieces identified as stove burners and cooking vessels. Finally, informant Lillian Robinson (1987) specifically mentions a stove.

The recovery of a cast iron stove burner lid fragment in association with the house foundation in unit E588+00/N155 could be a coincidence, or it could suggest that the kitchen area was located in the northwestern corner of the house. If so, the kitchen would have been at the rear of the house, just across the backyard from the garden. Such a location would help isolate the smells and heat of the kitchen as much as possible in the hot summer months. It would have been in a room adjacent to the living area with the fireplace, thus helping concentrate heat sources during winter. In the cold months, the warmer areas of the house could have been utilized more heavily for sleeping areas.

Families at the turn of the century living in rural farmhouses often utilized their space in a less formal manner, using rooms for multiple purposes that changed with the seasons to best 
The Rubin Hancock Farmstead, 1880-1916

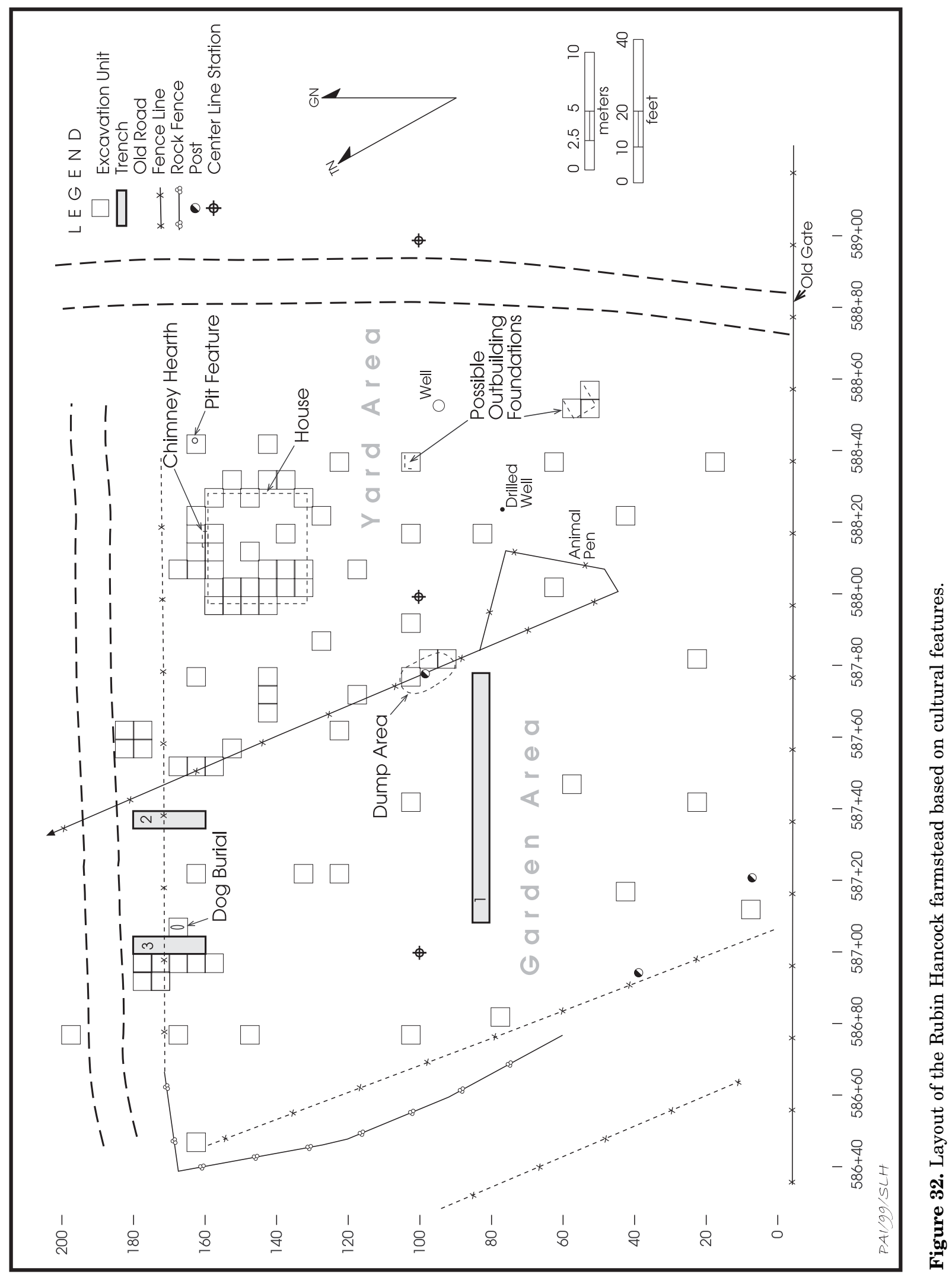


suit their needs. Such was the case in the ca. 19001946 Mission household in Calhoun County, Texas (Gadus et al. 1999:169), as well as at the ca. 1910 Moser farmstead in Arkansas (StewartAbernathy 1986:132-133).

By far, the best corroborating evidence concerning the farm layout is that provided by the 1937 aerial photograph of the site area (Figure 33). This photograph was taken after Rubin's death in 1916 but before the house was moved in 1942. The high degree of correlation between the archeological and photographic evidence suggests that the layout of the farm changed little over those years. None of the smaller farmstead features, such as the well, are visible in the photograph due to the scale, the poor resolution, and the tree cover. However, the larger use of space and its divisions are clear.

The west end of the house can be seen peeking out from under a copse of trees, and the gable-end roof can be seen. The yard is visible in the areas around the house, especially to the south and west. There is a clear delineation visible between the yard and the distinctive parallelogram-shaped garden area to the west. Roads border the core homestead to the north and east, while a smaller road runs along the south side. Large cultivated fields lie to the east of the site. To the west are wooded areas and small agricultural plots or pastures.

\section{Artifact Patterning}

One of the primary goals originally set forth for research at 41 TV875 was to examine the "horizontal patterning of artifacts and the functional pattern of artifacts as a manifestation of culture" (Clark 1985b:7). Therefore, as part of the work reported here, distributions of selected artifact classes were plotted and an analysis of those distribution patterns was attempted. Because most of the historic component was in very thin deposits, vertical distributions were not investigated.

The distributions of 12 artifact groups were examined: all artifacts, refined ceramics, utilitarian ceramics, table glass, all container glass, olive green container glass, solarized container glass, tin can fragments, window glass, cut nails, wire nails, and personal artifacts. These groups were selected because they were considered to be the most appropriate for addressing questions relating to changes in the use of space over time and for locating activity areas across the farmstead. For example, the distribution of cut nails vs. wire nails could potentially pinpoint areas of later construction or repairs, as denoted by the clustering of wire nails. In another example, differential distribution patterns of refined ceramics vs. utilitarian ceramics could denote different activity areas in the yard, such as the difference between an actual work area (utilitarian ceramics) and a refuse disposal area (refined ceramics). The results of the distribution studies are of varying utility.

One of the most informative distribution maps proved to be the patterning of all artifacts across the site (Figure 34). While all of the excavation units yielded artifacts, there is a notable difference in total artifact counts between units in the northern half of the site and those in the southern half. All of the units with high artifact counts (108+) and most of those with moderate frequencies (45-100) are in the northern part, while most of the southern units have low frequencies (2-41). This concentration of artifacts in the northern half of the site relates to the use of space.

The Hancock house was located in the northeastern section of the study area. Between the house and the fence to the west would have been a small back yard area (see Figure 32). The area immediately around the house and in the back yard would have been heavily utilized work spaces for performing both household and farmstead tasks by the entire Hancock family, and this appears to be reflected in the high artifact densities there. The recovery of artifacts in an area that would have been under the house suggests that the foundation of the structure might not have been continuous or closed. Instead, it could have been similar to piers that would have lifted the house above ground level, leaving a crawl space underneath. Over the long years of occupation by the Hancock family, materials made their way under the house, possibly by yard sweeping, a practice that informant Lillian Robinson (1987) reported.

The house and yard were separated from the garden to the west by a fence, and high artifact counts from units along this fence indicate that this area was utilized for refuse disposal. The presence of a surface dump (see Figure 32) supports this conclusion. The area at the northern edge of the garden appears to 


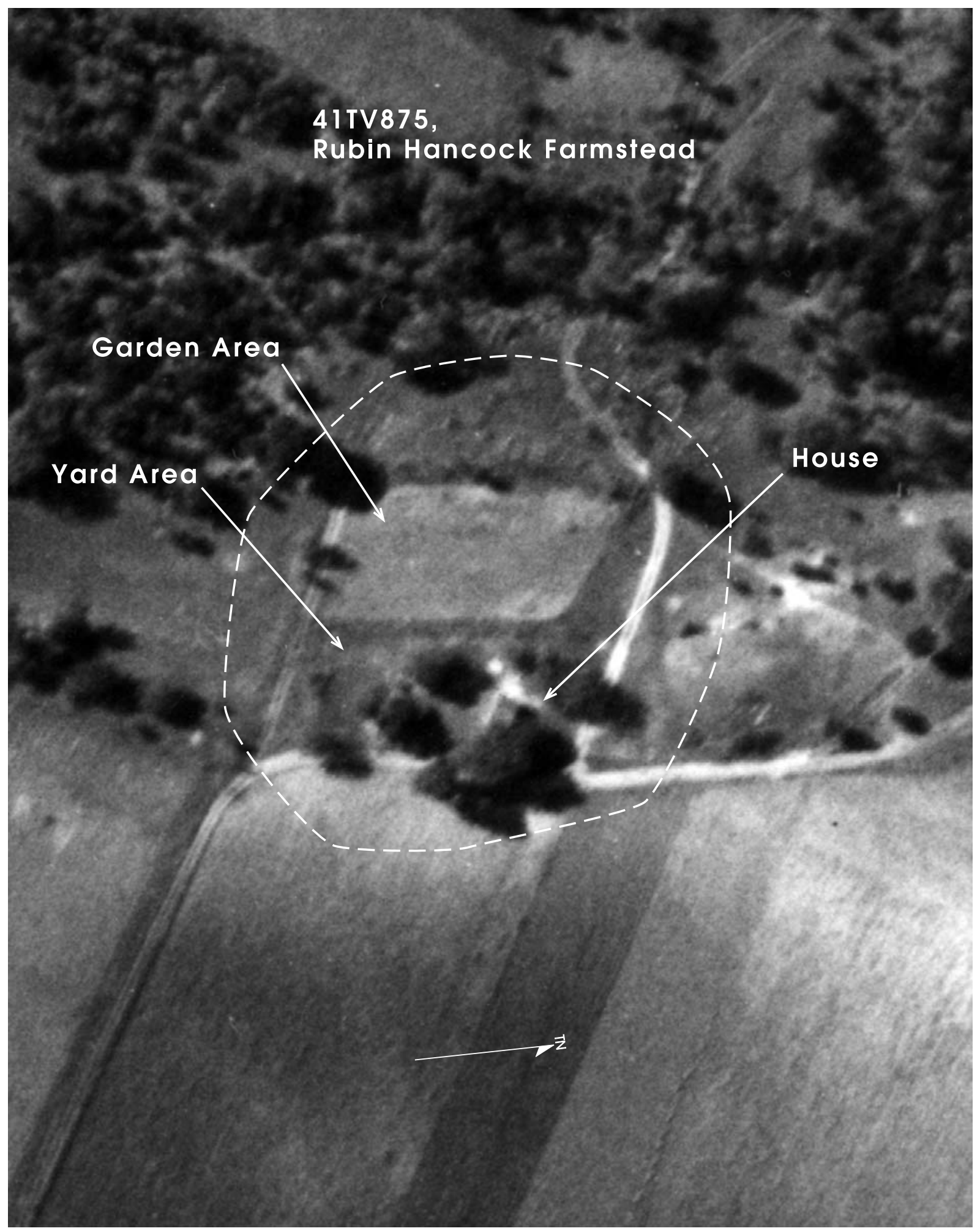

Figure 33. 1937 aerial photograph showing the Rubin Hancock farmstead. 


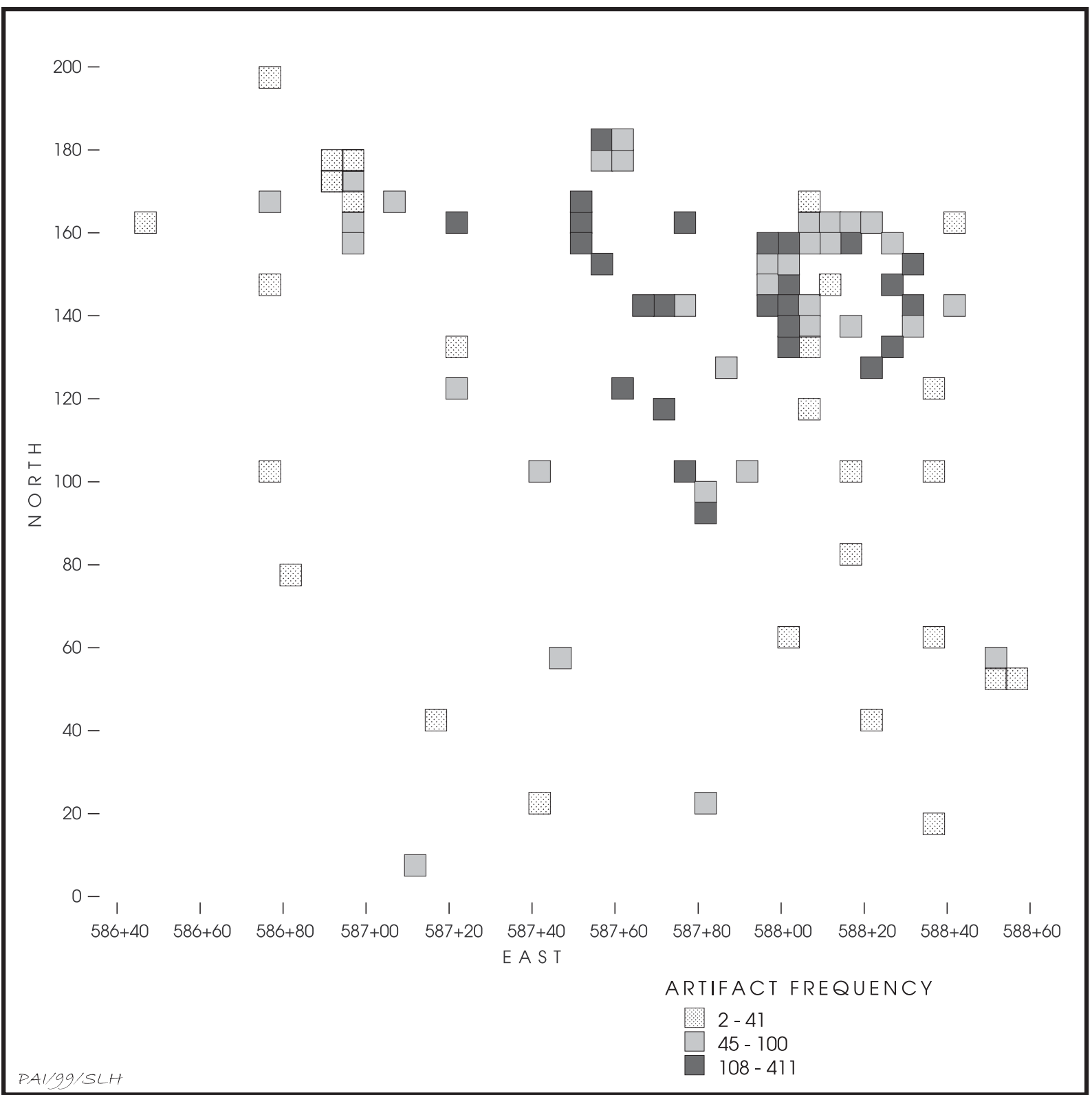

Figure 34. Horizontal distribution of all artifacts.

have been used in a more limited fashion for trash discard as well, based on the presence of the dog burial and six units with moderate to high artifact counts.

The generally sparse artifact recovery from the garden area proper emphasizes the fact that the garden would have been active with planting, cultivation, and harvesting, and would not have been used as a place to dispose of nonbiodegradable refuse. The generally low artifact counts in the southern part of the yard near the wells, the animal pen, and the possible outbuildings suggest that this portion saw less intensive activity, although it likely experienced substantial traffic to and from the well, the garden, the animal pen, and the possible outbuildings.

The two largest artifact categoriescontainer glass (recovered from 91 percent of the units) and tin can fragments (recovered from 
89 percent of the units)—have distributions that nearly mirror the total artifact distribution. These are concentrated around and under the house, in the back yard, and along the fences at the east and north sides of the garden, apparently reflecting a mix of household activities, yard sweeping, and trash disposal. Solarized glass is a subset of container glass and was recovered from fewer units (47 percent), but it also was concentrated around the house and in the back yard near the garden fence. Another smaller subset, olive green glass, was found in 24 percent of the units, with the highest frequencies also in the back yard near the fence.

Two other large artifact categories-cut nails (recovered from 84 percent of the units) and wire nails (recovered from 68 percent of the units)—have distributions that are quite similar to one another but somewhat different than the total artifact distribution. Not surprisingly, the nails are especially concentrated in the house area (Figure 35); only cut nails are illustrated because of similarities in the two distributions. These undoubtedly represent items lost during construction and repair of the house over the years, with some, perhaps, reflecting limited dismantling when the house was moved. The similarities in the distributions of the two nail types do not point to any temporal trends in construction and repair. Both cut and wire nails were recovered in moderate numbers from the units at the possible outbuilding foundations (see Figure 32). This lends support to the functional identification of these areas and suggests that the outbuildings were part of the original farmstead.

The other class of architectural items, window glass, was much less widely distributed (recovered from only 14 percent of the excavation units) and was found only along the west side of the house and in the small back yard just to the west. Details of the super11structure's construction are sparse, but it is known that the house was a square frame structure with a gabled roof. The number of windows and their placement on the different façades are not known. Likely, there were windows on more sides of the house than just the back, despite the fact that window glass was recovered only from that area. It is possible that the distribution pattern observed relates to moving the house ca. 1942, rather than any activity that took place during the Hancock occupation. For example, the windows may have been removed preparatory to moving the house and stored in the back yard.

Also concentrated in the house area are personal items (Figure 36). Fifty-five percent of the units yielded artifacts in this category, and all 13 units with high frequencies are immediately around or under the house. Some of these may be items that were lost through the floorboards of the house rather than discarded.

Three categories tend to occur mostly in the yard behind the house and along the garden fence to the west, with lower frequencies in the immediate vicinity of the house. These are refined earthenware (recovered from 39 percent of the units; Figure 37), utilitarian ceramics (recovered from 23 percent of the units), and table glass (recovered from 13 percent of the units). This distributional pattern appears to reflect primarily intentional trash disposal near the fence separating the yard from the garden. The fact that the two types of ceramics are distributed similarly suggests that their occurrence cannot be tied to activity areas in the yard.

\section{CONSUMER BEHAVIOR}

This artifact assemblage, primarily items representing glass bottles and tin cans, provides some interesting insights into the consumer products purchased and utilized by the Hancock family. As previously mentioned, these two categories of artifacts make up 45 percent of the assemblage.

Recent scholarship by Mullins (1999) provides a new context in which to interpret consumer behavior and data on commercial goods from African American archeological sites. Mullins's work is a comparison of latenineteenth- to early-twentieth-century African American occupation sites of varying economic status in Annapolis, Maryland. Several aspects of African American consumer behavior are examined, some of which are especially relevant to a study of the Hancock family. Mullins notes a marked pattern of the consumption of nationally produced brands with a corresponding lack of locally produced products, as identified by goods packaged in embossedlabel bottles (Mullins 1999:25).

During the study period, the most common 


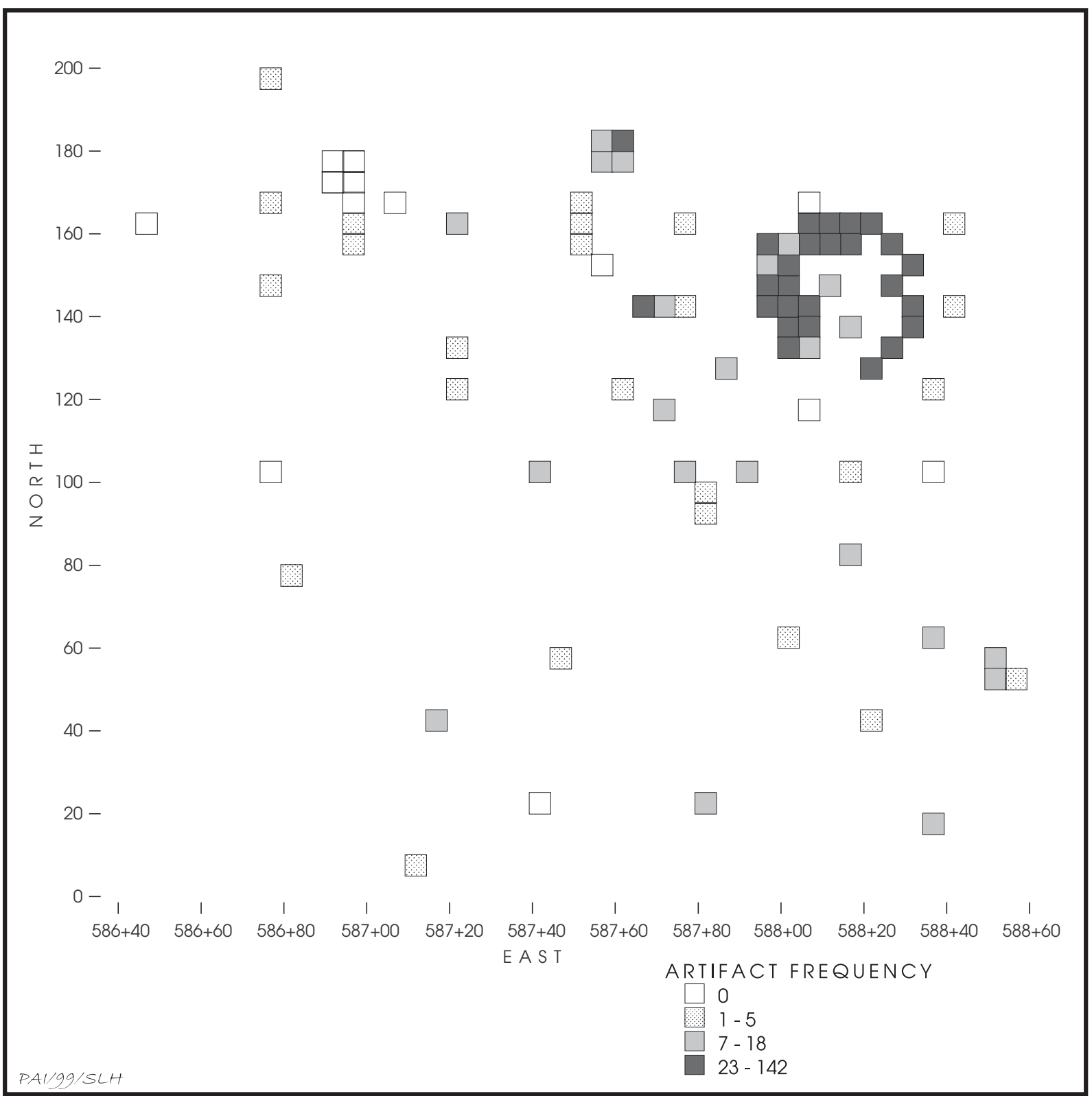

Figure 35. Horizontal distribution of cut nails.

and economical source of goods took the form of bulk dry goods sold from barrels, as loose goods, or locally bottled products sold by community merchants; such products were easily altered or adulterated, and could be of questionable quality. Goods purchased in bulk would leave very little archeological evidence, although local products packaged in bottles or jars might be marked with the name of the local business.

In contrast to bulk or loose goods, the $1870 \mathrm{~s}$ saw an increase in the distribution of nationally produced brand-name products in sealed containers. The wider distribution market made them accessible to a larger group of consumers. Nationally produced brands purchased either from catalog or via community merchants were goods produced, packaged, and sealed outside the local market, whether bottled, bagged, wrapped in paper, or canned (Mullins 1999:25). A huge variety of goods were available 


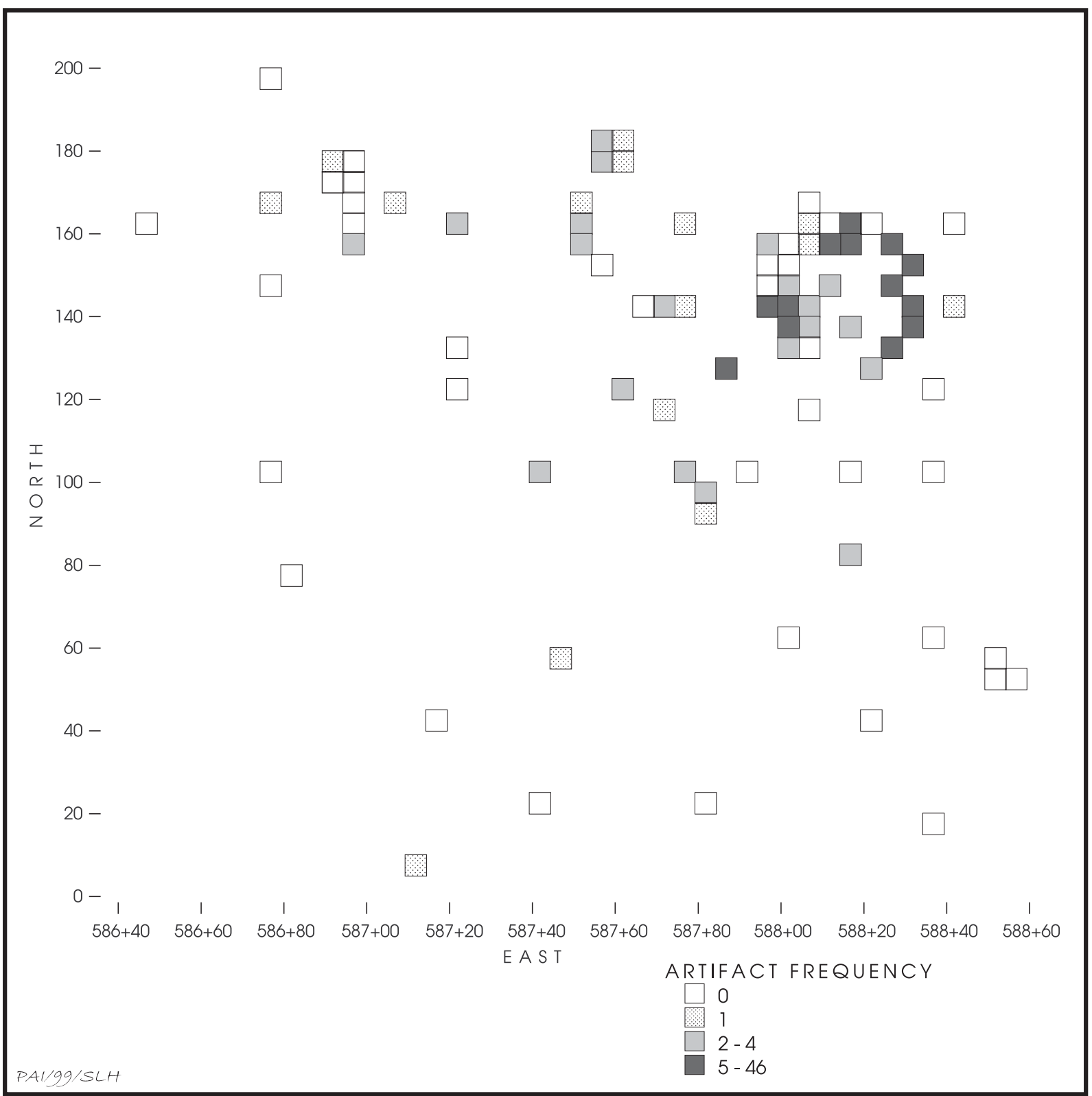

Figure 36. Horizontal distribution of personal items.

commercially, including food, beverages, condiments, medicines, beauty aids, and cleaning products. Archeologically, the remains of their packages or containers, most commonly tin cans and glass bottles and jars, would represent those products. Such containers potentially can be identified as to contents and point of manufacture based on embossed labels and makers' marks, thus enabling a study of consumer access and choice. Because of the limits of the 41 TV875 assemblage, it is not known to what degree the Hancocks utilized store vs. catalog shopping. However, it is possible that such questions could be pursued with a more appropriate and larger assemblage. By identifying labeled or marked containers, they could be sorted into groups of local goods (designated by a local business name), brandname goods (designated by a nonlocal business location with a wide commercial distribution), 


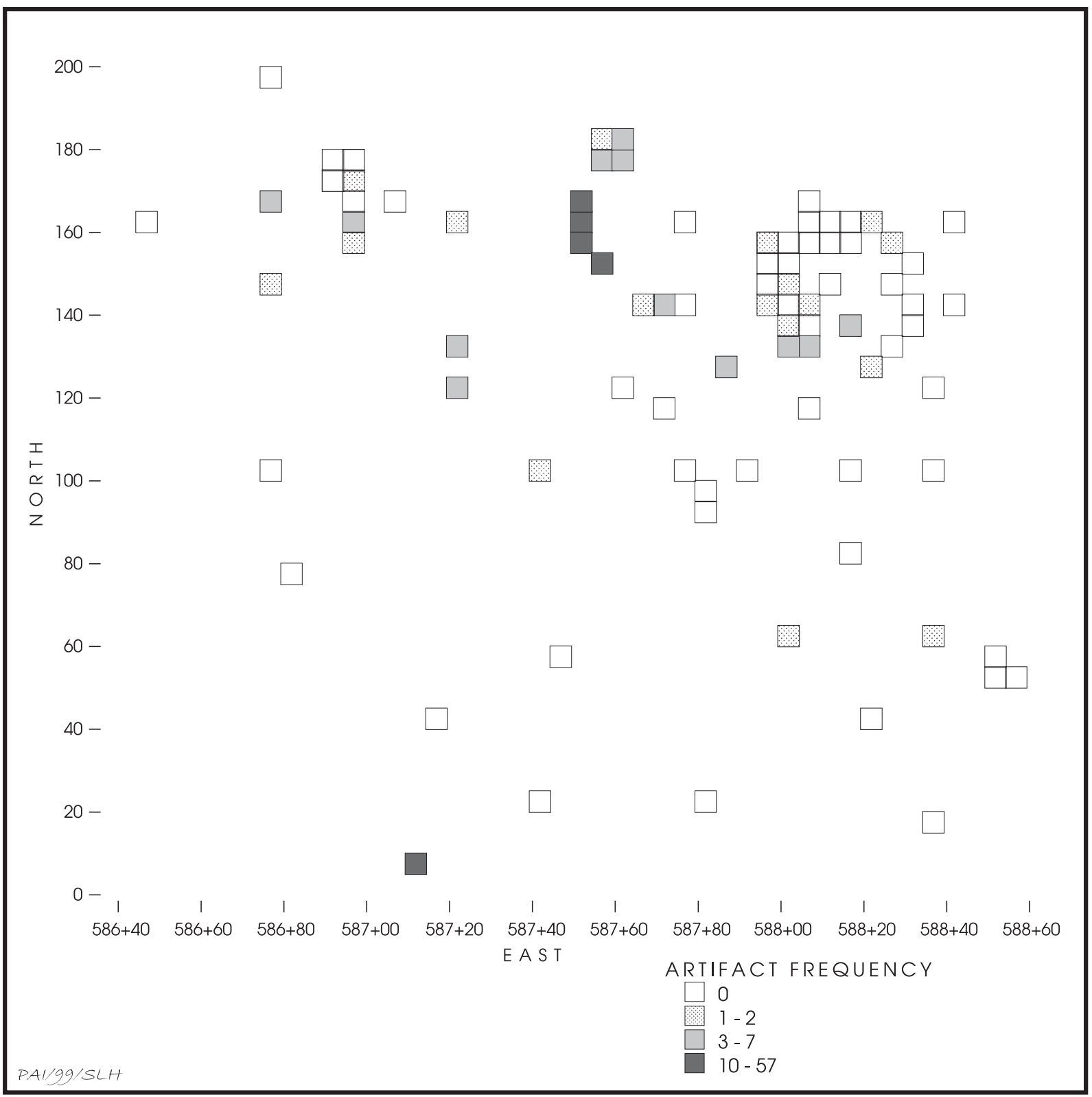

Figure 37. Horizontal distribution of refined earthenware.

and catalog goods (designated by brandnames only sold through catalogs, such as Sears).

For the consumer, commercial products provided goods of guaranteed quantity and quality. Mullins (1999:25) argues that brandname "consumption was a tactic which circumvented local marketer's racism and reflected African Americans' aspiration to the consumer privileges trumpeted in brand advertising". Several facts about the Hancock family suggest that they might have practiced consumer tactics that emphasized value for purchase price as well as a kind of "conspicuous consumption" of the type equated with successful members of the dominant society. Containers such as bottles and cans from commercial goods dominate the artifact assemblage recovered from their farmstead. Although few are identifiable as to definite point of origin, none of the consumables appear to be 
local, and products from outside the local market are definitely present, such as Rumford's from Rhode Island and Norton Brothers of Chicago. Canned foods and other products are by definition sealed containers, and they are in ample evidence. It is important to note that Rubin's son-in-law, Crawford Walker (husband of Martha Ann) had his own cannery operation, thus suggesting a potential source of local yet reliable canned food for the neighboring African American population.

An African American community certainly was present in the area where the Hancock family lived, but it lacked community services such as a store. By necessity, African American consumers would have been able to shop only at stores owned by whites. By purchasing namebrand products in sealed containers from such stores, African American consumers in the Duval/Waters Park area would have been assured of the quality and value of that purchase. Alternatively, any catalog purchase would have proved sufficiently anonymous so as to avoid any racism in the consumer transaction. As an African American community established by individuals who all had been slaves, there is no doubt that in one form or another, subtle or overt, these people experienced racism and in turn sought autonomy and success in their lives after emancipation.

Mullins makes an additional point directly linked to archeological evidence that might be relevant to the Hancock site. He cites several studies in Maryland and Washington, D. C., that found comparatively large numbers of buttons on African American sites. He correlates those findings with archival evidence of large numbers of African American women employed in service positions such as laundresses, domestics, seamstresses, and cooks (Mullins 1999:33). At the Hancock farmstead, no archival evidence was available about any additional employment that the Hancock women might have had. This primarily is due to the fact that census enumerators in the area routinely listed very little information about female occupations. Based on historical trends, the recovery of buttons, clothing fasteners, buckles, and sewing equipment at the Hancock farm is at least suggestive that one or more of these women could have been taking in laundry or sewing as a means of earning supplemental income.
As an archeological comparison, data on the percentage of buttons in total artifact assemblages were examined for 20 latenineteenth- to mid-twentieth-century Texas farmstead sites. In addition to 41TV875, the sites consist of: 1 from the Friendship community in Delta County (41DT208); the main occupation of the Ned Peterson family in Brazos County (41BZ115); 1 from the African American community at Long Mott in Calhoun County (41CL9); 6 from the Richland Creek area in Freestone and Navarro Counties (41FT156, 41FT163, 41FT164, 41NV102, 41NV267, and 41NV306); and 10 from the Joe Pool Lake area in Dallas and Tarrant Counties (41DL181, 41DL183, 41DL190, 41DL191, 41TR39, 41TR40, and two components at 41DL192). Of the 20 sites, 7 represent African American landowners, 2 represent African American tenants, 2 represent Anglo American tenants, and 9 represent Euro-American (Anglo, German, and French ancestry) landowners (Carlson 1995; Gadus et al. 1999; Green et al. 1996; Jurney et al. 1988; Jurney and Moir 1987). Buttons represent an average of 0.25 percent of the total assemblage for these sites. In comparison, buttons from the Hancock farmstead represent 0.5 percent of the total assemblage, twice the average. Although the overall numbers are not large, they are at least suggestive of an activity not readily observable via other data. As Cheek and Friedlander (1990:55) note in their discussion of ethnicity and material culture correlates, trends such as relatively high frequencies of buttons on African American sites "can be seen as differences in behavior that are due to membership in an ethnic group. ... As such they relate to everyday behavior that continually reaffirms the existence of a group." In this case, the behavior could be the common practice of African American women taking in sewing and laundry to earn supplemental income.

\section{INTERSITE COMPARISONS}

One of the goals of most archeological data recovery projects is to include comparative data to make the recognition of larger trends and patterns possible. The scale of the analysis is changed from looking at a single site, to adopting a more general community or societal perspective. However, for such a task to be 
possible, data sets must be comparable. The information must be gathered, analyzed, and presented in an analogous fashion. These requirements become problematic when examining turn-of-the-century farmsteads in Texas. Most of the work has been undertaken by different researchers from different institutions, at different times, and with different research questions. Since there is no one standard approach, finding a comparable data set for the Rubin Hancock site is a challenge.

\section{Waters Park, Travis County, Texas}

One of the most obvious choices is to look to the draft report of work done immediately to the south for the Waters Park project. Clark (1998) presents an incredible amount of information about the histories of the families associated with the archeological sites impacted by the construction of a north addition to MoPac (Loop 1). All these sites are at least superficially connected to 41TV875 in that they are in the same area, represent the same general time period, and relate to the same groups of people who lived in the Waters Park/Duval area at the same time as the Hancock family. Despite the seemingly easy connections, several factors make comparisons difficult.

The Parmer Lane extension project involved one site- the Rubin Hancock farmstead-while the MoPac extension project involved approximately eight sites of widely varying types. Historic sites recorded in the right of way include 41TV391 (the Rogers Spring site, mostly nineteenth century), 41TV291 (J. P. Wallace site, mid nineteenth century), 41TV632 (railroad section house), 41TV633 (Summers site, ca. 18721950), 41TV634 (tavern, twentieth century), 41TV635 (community dump, early to mid twentieth century), and 41TV636 (Waters Park bridge, early twentieth century) (Clark 1998:1521). While the MoPac extension sites have been analyzed to a point, the report on this work has not yet been finalized. In addition, the research emphases for the projects were distinctly different. Clark's (1998) stated paradigm is one of cultural ecology, whereas this study more heavily emphasizes the importance of historical and societal context.

Clark's emphasis on the historical importance of ecology in the lives of families is well taken in that most of the families in the project area were farmers. The success or failure of farming as an economic venture is highly dependent on ecological factors such as soil quality, access to water, and the vicissitudes of weather. In that respect, the experiences of the families associated with the various sites would have been very similar. The interpretive power of a cultural ecological paradigm lessens, however, when analysis focuses on the historical context within which these communities were set.

Nature does not discriminate when beleaguering the land with drought, flood, or insect infestations. However, the resources with which a farmer can respond to bad times, be they due to nature's wrath, illness in the family, or other factors, historically were linked to the hierarchical divisions of society based on race. Archival research in the project area clearly illustrates that, after emancipation, farms under white ownership were consistently larger, more valuable, of better quality, and more productive. This in no way reflects any lack of effort or expertise by African American farmers. These African Americans were the same people who had, before emancipation, been responsible for the success and bounty of their White masters' farms and plantations. Once freed, African Americans faced much resentment and many obstacles. Many families, such as those of the four Hancock brothers, had to start from the very beginning. The fact that they did become landowners and successful farmers is due entirely to their tenaciousness as individuals and their cooperation within the collective African American community.

Clark (1998) characterizes this area as a "multi-ethnic community," implying racial harmony and thus appearing to gloss over the issues of interaction. It is true that Waters Park and Duval had inhabitants who were of different racial backgrounds, but they still segregated themselves into their own cultural groups. Descriptions of life in the Duval-Waters Park area in the early twentieth century by informants Lillian Robinson (1987) and Alma Shelby (1987) make it clear that interaction between Anglo Americans and African Americans was limited. African Americans generally operated within their own sphere with their own churches, schools, friendships, and family ties. Although Waters Park was marketed 
primarily as an excursion locale, most African Americans did not interact with tourists to the area. Instead, exchange between the groups took the form of African Americans selling surplus farm products to local merchants or individuals. Eggs were sold in Austin, whereas local White merchants brokered chicken, milk, and butter. In exchange, staple products were purchased. Apparently, the two or three local stores sold "ice, canned goods, sugar, coffee, bacon, candy, cartridges and kerosene, but no fresh produce" (Clark 1998:26). Some surplus produce from African American farms was sold via local stores, or could be bought "downtown," presumably in Round Rock or Austin (Robinson 1987).

Some African Americans also worked for Whites doing seasonal farm tasks. Clark (1998:27) notes that "much of the farm labor was done by local black families." A few of the men worked for the railroad, and some women worked as domestics/servants in White households (including the Governor's Mansion and the Capitol). African American women taught school at St. Stephens, and one woman, Fanny Hancock, served as the local midwife (Robinson 1987). Generally, Blacks and Whites led very separate lives.

Another central theme for the Waters Park study is the change "brought on by the construction of railroads through the project area resulting in the building of the community of Waters Park" (Clark 1998). In this respect, Clark and the authors of this volume came to the same conclusions about the impact of the railroad on Duval and Waters Park. In terms of establishment of the town centers, Duval was relatively unsuccessful despite its proximity to railroad access and development efforts. In contrast, the very existence and survival of Waters Park were linked directly to the presence of the railroad. Its primary function as an excursion destination was made possible by the railroad, and once its appeal as such waned, it fell into decline (Clark 1998:42).

Some of the best comparisons between the Waters Park project and the Hancock farm research can be made with reference to the railroad and its differential use patterns by Black and White populations in the area. Most of Clark's (1998) commentary about the railroad focuses on the larger societal impacts of its presence. As stated, Waters Park owed its existence to the railroad. By extension, the same could be said of most of the White-owned businesses in Waters Park, which were fed by "excursion trains [that] brought people from Austin to play ball, picnic, and go swimming" (Clark 1998:2). Most of the families mentioned as being associated with the park and the businesses, either as patrons or owners, were White.

The African American community seems to have maintained a very different relationship with the railroad and the transportation opportunities it allowed. Both Lillian Robinson (1987) and Alma Shelby (1987) stated that their families did not ride the train. Instead, a horse and buggy were used for transportation. However, the railroad was used as transportation for goods. Most families produced farm surplus that was sold for cash. Cotton, corn, cane, milk, and cheese were loaded on the train at the Duval station and shipped to Round Rock for sale (Robinson 1987).

Although some Black families did picnic at Waters Park (Shelby 1987), for the most part their lives were parallel but separate from those of Whites. Families in Duval also enjoyed playing baseball, having picnics, and attending concerts. But most commonly these activities were coordinated with St. Stephens Church and were held on church grounds (Robinson 1987; Shelby 1987).

\section{The Town of Friendship, Delta County, Texas}

Perhaps more suitable for comparisons with the research done at the Rubin Hancock farm is the study done of the African American town of Friendship in Delta County, Texas. Although located in northeast Texas, the community there shows many intriguing similarities to Duval. In 1994, Geo-Marine, Inc., conducted "an intensive archival and oral history review, coupled with limited archaeological investigations, of the small post-Reconstruction era African American com-munity of Friendship" as a part of the cultural resources management program at Cooper Lake (Green et al. 1996:xi). Three farmsteads were examined: 41DT192 (John Derrick, ca. 18971956), which also included a sorghum mill, store, and restaurant; 41DT208 (John Hancock, ca. 1889-1920s); and 41DT249 (Wallace 
Carter, ca. 1917-1958) (Fields et al. 1997:99). Just as Duval was linked to Waters Park, Friendship had a relationship with the nearby White community of Klondike. Indeed, these two pairs of related towns seem to have had many commonalities. Green et al. (1996:45) state that "Friendship can be considered a community although it lacked any real commercial endeavors within its boundaries" which served to link it closely with the businesses available in Klondike. In a similar way, Duval was linked with the surrounding White communities, especially Waters Park, as a source of commercial access. Another way in which Friendship mirrors Duval is that the three archeological sites studied at Friendship all represented African American landowners, just as Rubin Hancock and his brothers were landowners.

The depiction of Friendship and Klondike emphasizes peaceful interaction, which also would be a fair characterization of Duval and Waters Park. Green et al. (1996:36) explain this relationship in terms of acculturation, that is, "the processes and results of former slaves adapting into the dominant white culture in order to survive the stresses experienced after freedom." However, issues of racism and segregation are not emphasized.

In terms of archeological research, the excavations included in the study are not analogous to those undertaken at 41TV875. Only testing-level subsurface investigations were undertaken, whereas the Hancock farm was the subject of mitigative excavations over a much larger area. As a result, the artifact assemblage recovered at 41 TV875 is much larger than those recovered at any of the three Delta County sites. Only 41DT208, the John Hancock site (probably no relation), has a similar period of occupation, ca. 1889-1920s. The other sites were occupied well into the 1950 s and had suffered more impacts.

Although 41DT208 is the best candidate for comparison, a brief synopsis of the site reveals its limitations. The 24-acre John Hancock farm was purchased in 1889, and additional land was rented for cotton production (Green et al. 1996:101). Research indicates that there was a frame house with a mudcat chimney. It was theorized that the house underwent multiple renovations to accommodate the 10 children in the family. Informants identified a possible barn area as well. The area was tested with fifty-two $0.5 \mathrm{x} 0.5-\mathrm{m}$ test pits and six backhoe trenches. No historic surface features were identified with the exception of ornamental plants, and only one subsurface feature was identified, the probable remains of the chimney. A total of 1,538 artifacts were recovered from testing, which were categorized into the following groups: domestic/furnishings $(\mathrm{n}=694)$; architectural ( $\mathrm{n}=$ $600)$; personal $(\mathrm{n}=43)$; activities $(\mathrm{n}=42)$, and indeterminate $(n=159)$ (Green et al. 1996:99 116). The artifacts identified are types common to historic sites of this period. Because of the differences in numbers of features identified, volumes of sediment excavated, and assemblage sizes, only basic comparisons are possible.

Despite the limitations of the three Delta County sites, by combining their archeological data with copious archival and oral history information, a profile of African American farming at Friendship was developed. Several propositions are put forward. Initially, to be a successful African American land-owning farmer, a degree of racial tolerance must exist among the Anglo population in a given area. Green et al. (1996:35, 36) point out that, in 1890, 26 percent of the African American population of Texas were landowners. By 1900, that number had increased to 31 percent. Although that still represents a minority of the population, obviously in some communities African Americans were finding people from whom to buy land. In the case of African American land ownership in Duval, this proposition is at least partially true, although the degree to which their former master might have helped the four Hancock brothers remains unresolved. Despite that, there is evidence that Blacks purchased land by their own hard work. The interplay between Whites selling land to prospective Black buyers in Duval was somewhat buffered by the fact that Anderson Peoples bought a large tract of land and then sold portions of it to family members.

The next proposed requirement for land ownership is money for the purchase. Green et al. (1996:36) note various ways in which an African American could have raised such funds-severance from former masters, land sold on credit from former masters, and by making public land claims. But by far, the most common technique was sharecropping. Research indicates that Rubin Hancock sharecropped on 
his land before its purchase. Also, the other Hancock brothers raised money for land acquisition by performing farm labor.

According to Green et al. (1996:36), the establishment of a successful African American farmstead also is dependent on accessibility to freshwater springs and creeks and the suitability of the soil for cotton farming. This certainly appears to be true for central Texas, as was pointed out by Clark (1998). Rubin Hancock's farm was situated next to Walnut Creek-an excellent source of water. However, since the agricultural products were somewhat more diversified in central Texas than northeast Texas, the dependency on cotton farming and the importance of soil suitable for it were lessened. In addition to some cotton, Rubin grew corn, oats, sweet potatoes, potatoes, and vegetables, and he produced dairy products.

The final proposition is that a successful African American farm needed to have an efficient division of labor within the household. Families studied at Friendship were large and sometimes composed of extended families. Tasks were assigned by sex and age, and some chores were undertaken by entire families (Green et al. 1996:36, 39). To some extent, this statement is true of all farm families, despite ethnicity, although cooperation among families and within the African American community was a somewhat more important survival technique than within the larger, white-dominated society. Within the families of the four Hancock brothers, apparently all family members worked, and it is probable that members of the extended family assisted one another as needed. As for Rubin Hancock's family, the amount of division of labor varied over time. While the Hancock children were young, they would have had a different set of tasks than when they grew older. For most of the history of the family, Rubin was the only adult male present. Rubin and Elizabeth had only one son who died by the age of 21. The oldest daughter, Melvina, married and left home before the Hancock family bought their farm in the Duval area. Daughter Fannie also married and left the area. However, daughters Susie and Mattie married and stayed in the area. Because Elizabeth died in 1899, it was the families of Susie and Mattie who assisted Rubin on his farm.

Green et al. (1996:39) conclude by emphasizing the importance of family, com- munity, and the church in the success of landowning African American farmers. In Friendship, the Colored Methodist Episcopal Church established in 1885 provided a cohesive influence on the community just as St. Stephens did for the families at Duval.

\section{The Ned Peterson Farmstead, Brazos County, Texas}

Research at the Ned Peterson Farmstead (41BZ115) in Brazos County, Texas, provides another study with many similarities to the Rubin Hancock project. The site represents a single farmstead owned by an African American family and occupied primarily between 1893 and ca. 1913, although the land remained in the family until 1931 (Carlson 1995:iv). Brazos County is located in east-central Texas, which is geographically much closer to Travis County than the Delta County sites. In a similar manner to the Hancock project, archeology at the Peterson farm was augmented with copious archival and oral history information.

Work at 41BZ115 was carried out between 1993 and 1995 by the Center for Environmental Archaeology at Texas A\&M University (TAMU) as mitigation of impacts to the site by construction of TAMU's wastewater treatment plant along White Creek (Carlson 1995:vi). Like the sites examined at Friendship, the Peterson farm was examined archeologically only at the testing level (Thoms 1993). Thus, that excavation was carried out at a much smaller scale than those at the Hancock farm. The historical research of the Peterson farm was considered to be the appropriate mitigation, with results of previous testing simply incorporated into the larger research effort.

Turning to the archeology itself, a brief synopsis of the excavations at the Peterson farm illustrates more clearly how this site is and is not comparable to 41TV875. Ned Peterson's farming efforts actually are represented by two related sites, $41 \mathrm{BZ} 115$ and $41 \mathrm{BZ} 118$, both located on the bank of White Creek and on the 150-acre tract bought by Peterson in 1893 (Carlson 1995:9). Informants described the house as a dogtrot-type log cabin. Surface features consisted of a brick and sandstone rubble pile, a brick- and sandstone-lined well, and a large live oak. Aerial photographs dating from 1932 and 1940 aided in locating other 
farmstead structures (Carlson 1995:13). The primary site, 41BZ115, had been partially destroyed by a borrow pit. The remaining portion was defined as having three concentrations of artifacts. Two of these were investigated with seven $0.5 \times 0.5-\mathrm{m}$ test units and five backhoe trenches. The only subsurface feature encountered was a brick footing (Carlson 1995:13). The total assemblage recovered from both surface and subsurface contexts consisted of 1,063 artifacts, 54 percent of which was glass (Carlson 1995:15).

Site 41BZ118 was located approximately $2,000 \mathrm{ft}$ southwest of 41BZ115. Based on aerial photograph evidence, the sites historically were linked by a trail. Surface features consisted of a small stock tank, an artifact scatter, and a sandstone pile. No archeological testing was undertaken. The date of occupation was estimated at ca. 1888-1935 (Carlson 1995:17).

As with attempted comparisons with the Delta County sites, these two sites in Brazos County were the subject of much less excavation, had fewer surface and subsurface features, and much smaller artifact assemblages than the Hancock farm. Thus, neither is ideal for detailed comparisons. However, it is possible to make some comparisons on a general scale. Perhaps one of the most significant contributions to African American archeology presented in Carlson (1995:1-3) is a brief overview of current research and theory. It emphasizes that "research goals must go beyond the search for a forgotten people, ethnic artifacts and status differences" (Carlson 1995:1). This closely mirrors Mullins's (1999:25) objection to the constant practice of studying African American consumerism relative to the perceived white consumer "norm." Instead of pursuing those old paradigms, Carlson (1995:1) encourages "studies concerning prejudice and racism vs. those of interracial harmony."

Carlson's emphasis on the study of prejudice and racism vs. interracial harmony is the same idea Green et al. (1996) present as the key to a successful African American farmstead-racial tolerance. In all case studies cited, African Americans became successful landowning farmers primarily due to their own efforts, but also because they were given the opportunity to do so at a time when American society as a whole was rife with prejudice and discrimination.

There are several interesting similarities and differences between the Peterson and Hancock occupations. Like Hancock, Peterson acquired the land for his farm by purchase with money he had earned through sharecropping and wage labor (Carlson 1995:103). However, unlike any of the other studies examined, the sites associated with the Peterson family occupations were not linked directly to an African American community or town. It appears that there were several small surrounding communities, both black and white, where the Petersons went to church and could patronize various commercial establishments (Carlson 1995:103). For the Petersons, it seems that the support network of the extended family superceded that of the community.

\section{CONCLUSIONS}

This project had three goals that were pursued with archival, oral history, and archeological data from 41TV875, the Rubin Hancock farm. The first goal was to study consumer access to local and national markets. Archival research, especially of the agricultural censuses, revealed the extent to which Rubin Hancock's family, and those of his three brothers, contributed to and were independent of the market economy. Each farm produced subsistence crops and products to feed their own families, in addition to producing some surplus for sale. Rubin also grew some cotton that was exclusively a cash crop. In this respect, the Hancocks needed little from commercial markets and were themselves suppliers of farm goods to local urban markets. Oral history informants expanded that knowledge with discussions of specific details, such as the types of fruits and vegetables grown in the Hancock family gardens and orchards. Informants indicated that their farm surplus was loaded on the train at Duval for shipment to Round Rock, or sometimes sold to local White storeowners and sometimes even sold in Austin. They also noted that only certain staple goods and some manufactured products were purchased in the local stores that carried limited stock. The material culture assemblage recovered archeologically indicated that purchases were made of commercial goods, typically in cans or bottles packaged outside the local market. Preserved foodstuffs could have helped the family extend their ability to store 
food despite the lack of electricity or modern facilities. It also is possible that the purchase of prepackaged products allowed the Hancocks to avoid bulk items of questionable quality for sale in White-owned establishments.

The second goal was to study ethnicity and social status. Archival and oral history research were the most effective resources for this question. Many types of primary resources such as censuses (both population and agriculture), school records, marriage records, etc., include an indication of ethnicity. Therefore, it was possible to reconstruct the location and composition of different ethnic populations. It also was possible to learn that White-owned farms were worth more than Black-owned farms, but despite that the Hancocks were landowners in a time when many others of either ethnicity were sharecroppers or tenants. Informants were able to give first-hand accounts of their lives and experiences, as well as those of their families. It is only through them that racial interaction could be explored. Although there are no written records to document the familial links between the prominent, White Hancock family and the black Hancocks who had been their slaves, oral tradition was a rich source that linked them together in intimate ways. Archeological data were less effective at addressing questions of ethnicity, although some possible links were explored. However, social status can be linked directly to material culture. The Hancocks had acquired for themselves through their own hard work a comfortable life complete with both the necessities and some of the trappings of genteel respectability. Archeological remains indicated the presence of belongings such as Japanese porcelain, lead glass tableware, fasteners from dress clothes, and jewelry, just to name a few.

The third goal was to look at artifact patterning as a way to study culture. An examination of the horizontal patterning of certain artifact classes revealed how the Hancocks used space around their farm. The yard areas immediately around the house were utilized heavily for activities, whereas hightraffic areas were kept clean of refuse. Trash was dumped along fence lines and at the north end of the garden, but the garden area itself was relatively free of debris because it would have been active with planting, cultivation, and harvesting. Although this third goal was directed at utilizing archeological data, oral history did contribute as well. Informants provided descriptions of the farm and the activities carried out there. In this case, archival documents offered little data, with an exception of indicating which crops were grown on the farm.

Based on the comparative examples examined, both family and community solidarity were important factors in the history of African Americans in Texas. In each case, the nuclear family was cultivated carefully and served as the basic unit within which individuals functioned. Families worked together for their own common good to acquire both the necessities of life, as well as the finer things that were the markers of success. Extended families also often worked in a cooperative fashion that served to ensure the prosperity of all their members. At the very least, this kind of cooperative behavior was an effective adaptive technique. It is possible that the strong emphasis on family ties stemmed from similar values extolled in their African heritage. Most obviously, the importance of family was strongly encouraged in the American ideology which constantly surrounded them, but which they were not always allowed to participate in when they were slaves. Perhaps once they were given the opportunity, African Americans were eager to embrace the behaviors of equality that were approved of by the dominant society. Once emancipated, they were not stigmatized by fragmented family structures. By their own self-determination, they could live in whole family units with loved ones as they chose, and were no longer subjected to the will of a master.

Close familial ties also would have been encouraged by organized religion, and many African American families were active in various Christian congregations. As an extension of that trend, nuclear and extended African American families cooperated on an even larger community scale, oftentimes with the church playing a central role. These interlocking institutions galvanized African Americans into viable groups that helped their members survive and thrive even in the face of a generally hostile dominant society. In this way, it could be said that racism was a factor in the everyday lives of rural, central Texas African Americans at the turn of the century. They may 
not have had altercations on a daily basis, but they would have been well aware of societal constraints placed upon them that were derived from racist philosophies. The specific techniques employed to resist or avoid those constraints are difficult to document for the Hancock family specifically, but the possibilities could be numerous and variable.

In a final analysis in which all archival, oral, and archeological evidence is weighed together, a few defining characteristics of the Hancock farm and family become clear. Through a combination of accommodation and resistance, the family members put forth a great amount of effort to achieve a level of equality. Based on the material culture recovered from Rubin Hancock's farmstead, his family was not without pleasures and comforts. They worked hard for what they had, and they appear to have been able to reach a level of success. It appears as if they were seeking all the advances that emancipation and Reconstruction seemed to promise. They met with some triumphs and some defeats. All of the Hancock brothersRubin, Salem, Orange, and Peyton-were able to own their own farms. Each registered to vote and each married and had their own familiesmembers of which still prosper in the Austin area. The Hancock family was part of an African American community, and although it was not formally organized, it was closely linked by marriage and blood ties. This community had its own church and school. However, before these people came, nothing existed in this quiet locale north of Austin. All of these accomplishments were created by the will and effort of a group of people who had just come out of the bonds of slavery. They were survivors of slavery-not its victims. Freedom was sweet and they made the most of it. 

GLOSSARY OF TECHNICAL TERMS 
Cut Nails: Nails that are square in cross section and manufactured by a machine that sliced them from sheet iron. Most commonly used in nineteenth-century construction (Noël Hume 1991:253-254)..

Finish: A term used to describe entire upper portion of a glass container. The finish technically consists of the bore (opening), the lip (the external, upper part), and the string rim (a protruding ledge or ring near the top of the neck) if present. Glass containers can have any number of finishes, usually dictated by the function of the container and type of closure. Many distinctive finishes have specific names, such as a double-bead finish, a patent finish, or a straight finish (see text for examples) (Jones and Sullivan 1989:76-77).

Ironstone: Also called white granite, this is a semivitreous or vitreous white-bodied ware, often with molded decoration. Commonly used beginning in the $1840 \mathrm{~s}$, it was popular through the 1910s (Majewski and O'Brien 1987:120124).

McKinley Tariff: This 1890 tariff was designed to protect domestic industry by levying extremely high duties on imports, thus making it difficult for foreign goods to compete in the American market. One practical effect for the ceramics industry was the requirement of marking the country of origin on wares beginning in 1891, thus making it a useful dating tool (Godden 1964:11; Litwack et al. 1987:462).

Pontil: An iron rod used for the hand production of glass items. It can leave a variety of different marks on the finished product, indicative of the manufacturing process employed (Jones and Sullivan 1989:21).

Solarized Glass: Also commonly called amethyst or lavender glass. Solarized glass results from manufacturers producing colorless glass by including manganese as a decolorant. However, after prolonged exposure to the ultraviolet rays of the sun, glass made with manganese turns a pale purple. This manufacturing technique was most common from the last quarter of the nineteenth century until World War I (Jones and Sullivan 1989:13).

Tang: A projection by which a tool or utensil, such as a fork, is attached to its handle (Noël Hume 1991:178).

Whiteware: A nonvitreous white-bodied earthenware most commonly used after 1820 (Majewski and O’Brien 1987:121).

Wire Nails: Nails that are round in cross section and made by machine. Wire nails were not used commonly until the late nineteenth century and most are associated with twentieth-century construction (Noël Hume 1991:254). 


\section{REFERENCES CITED}

Anderson, John Q.

1967 John C. Duval: First Texas Man of Letters. In Southwest Writers Series 2, edited by James W. Lee. Steck-Vaughn Company, Austin.

Austin Democratic Statesman

Barber, John L.

1987 The Rimfire Cartridge in the United States and Canada: An Illustrated History of its Manufacturers and their Products, 1857 to 1984. Armory Publications, Tacoma, Washington.

Barnes, Frank C.

1993 Cartridges of the World. 7th ed. DBI Books, Inc., Northbrook, Illinois.

Bastrop County

Deed Records

Bender, Nathan E.

1986 Early 20th Century Commercial Closures. Paper presented at the annual meeting of the Society for Historical Archaeology, Conference on Underwater Archaeology, Sacramento.

Bente, Vance G.

1976 Good Luck, Long Life. In The Changing Faces of Main Street, edited by Roberta S. Greenwood. San Buenaventue Redevelopment Agency, Ventura, California.

Boyd, Douglas K., Jay Peck, Steve A. Tomka, Karl W. Kibler, and Martha Doty Freeman 1994 Data Recovery at Lake Alan Henry (Justiceburg Reservoir) Garza and Kent Counties, Texas: Phase III, Season 3. Reports of Investigations No. 93. Prewitt and Associates, Inc., Austin.

Busch, Jane

1981 An Introduction to the Tin Can. Historical Archaeology 15(1):95-104.

Campbell, Randolph B. 1996 Slavery. In The New Handbook of Texas,
Vol. 5:1081-1083. The Texas State Historical Association, Austin.

Carlson, Shawn Bonath (editor)

1995 African American Lifeways in EastCentral Texas: The Ned Peterson Farmstead (41BZ115), Brazos County, Texas. Reports of Investigations No. 3. Center for Environmental Archaeology, Texas A\&M University, College Station.

Cheek, Charles D. and Amy Friedlander

1990 Pottery and Pig's Feet: Space, ethnicity, and Neighborhood in Washington D.C., 1880-1940. In Historical Archaeology, 24(1):34-60.

Claassen, Cheryl

1994 Washboards, Pigtoes, and Muckets: Historic Musseling in the Mississippi Watershed. Historical Archaeology 28 (2).

Clark, John W., Jr.

1985a Archaeological Testing and Preliminary Archival Investigations of the Ruben Hancock Site, 41TV875, Travis County, Texas. Texas State Department of Highways and Public Transportation, Highway Design Division, Austin.

1985b Research Design for Mitigation of the Ruben Hancock Site, 41TV875, Travis County, Texas. Texas State Department of Highways and Public Transportation, Highway Design Division, Austin.

1998 Under Four Flags: History and Archeology of Loop One North, Travis County, Texas (Draft report). Texas Department of Transportation, Environmental Affairs Division, Archeology Studies Program, Report 2, Austin.

Coleman, Mrs. Andrew

1999 Telephone interview with Mrs. Andrew Coleman, January 14, 1999, Austin, Texas, by Terri Myers. 
Collins, Karen

1999a Original research notes.

1999b Telephone interview with Karen Collins, January 18, 1999, Austin, Texas, by Terri Myers.

1999c 1999 Rosedale Ramble. Privately published, Austin.

1999d Interview with Karen Collins, May 12, 1999, Austin, Texas, by Terri Myers.

Costello, Julia G., and Mary L. Maniery

1988 Rice Bowls in the Delta: Artifacts Recovered from the 1915 Asian Community of Walnut Grove, California. Occasional Paper 16. Institute of Archaeology, University of California, Los Angeles.

Fields, Ross C., Marie E. Blake, and Karl W. Kibler 1997 Synthesis of the Prehistoric and Historic Archeology of Cooper Lake, Delta and Hopkins Counties, Texas. Reports of Investigations No. 104. Prewitt and Associates, Inc., Austin.

Fike, Richard E.

1987 The Bottle Book: A Comprehensive Guide to Historic, Embossed Medicine Bottles. Gibbs M. Smith, Inc., Salt Lake City.

Fontaine, Rev. Isaac III, and Gene Burd

1983 Jacob Fontaine: From Slavery to the Greatness of The Pulpit, The Press and Public Service. . . A Legacy of Church, Campus and Community. Eakin Press, Austin.

Fontaine, The Reverend Isaac III

1999 Interview with The Reverend Isaac Fontaine III, January 14, 1999, Austin, Texas, by Terri Myers.

Gadus, E. Frances, Marie E. Blake, and Karl W. Kibler 2000 The Prehistoric Components at the Rubin Hancock Farmstead, 41TV875, Travis County, Texas. Technical Reports No. 44. Prewitt and Associates, Inc., Austin

Gadus, E. Frances, Marie E. Blake, Martha Doty Freeman, and Karl W. Kibler

1999 National Register Testing of Prehistoric and Historic Sites and Survey of Placement Areas, Channel to Victoria Project, Calhoun and Victoria Counties, Texas. Reports of Investigations No. 121. Prewitt and Associates, Inc, Austin.
Gates, William C., Jr., and Dana E. Ormerod 1982 The East Liverpool, Ohio, Pottery District: Identification of Manufacturers and Marks. Historical Archaeology 16 (1-2).

Godden, Geoffrey A.

1964 Encyclopaedia of British Pottery and Porcelain Marks. Bonanza Books, New York.

Green, Melissa M., Duane E. Peter, and Donna K. Shepard

1996 Friendship: An African-American Community on the Prairie Margin of Northeast Texas. Miscellaneous Report of Investigations No. 81. GeoMarine, Inc., Plano.

Greer, Georgeanna H.

1981 American Stonewares: The Art and Craft of Utilitarian Potters. Schiffer Publishing, Ltd., Exton, Pennsylvania.

Grist, Everett

1993 Everett Grist's Big Book of Marbles: A Comprehensive Identification and Value Guide for Both Antique and MachineMade Marbles. Collector Books, Paducah, Kentucky.

Headrick, Pamela

1993 A Draft Evaluation of Documentation and Materials from 41TV875, The Reuben Hancock Farmstead, Travis County, Texas. Texas Archeological Research Laboratory, The University of Texas at Austin.

Israel, Fred L. (editor)

19681897 Sears Roebuck Catalogue. Chelsea House Publishers, New York.

Jones, Olive

1986 Cylindrical English Wine and Beer Bottles, 1735-1850. Studies in Archaeology, Architecture and History. National Historic Parks and Sites Branch, Environment Canada-Parks. Minister of the Environment, Ottawa.

1993 Commercial Foods, 1740-1820. Historical Archaeology 27(2):25-41.

Jones, Olive, and Catherine Sullivan

1989 The Parks Canada Glass Glossary for the Description of Containers, Tableware, Flat Glass, and Closures. National 
Historic Parks and Sites Branch, Canadian Parks Service, Ottawa.

Jurney, David H., and Randall W. Moir

1987 Historic Buildings, Material Culture, and People of the Prairie Margins: Architecture, Artifacts, and Synthesis of Historic Archaeology. Richland Creek Technical Series, Volume V. Archaeology Research Program, Institute for the Study of Earth and Man, Southern Methodist University, Dallas.

Jurney, David H., Susan A. Lebo, and Melissa M. Green

1988 Historic Farming on the Hogwallow Prairies: Ethnoarchaeological Investigations of the Mountain Creek Area, North Central Texas. Joe Pool Lake Archaeological Project, Volume II. Archaeology Research Program, Institute for the study of Earth and Man, Southern Methodist University, Dallas.

Lebo, Susan A.

1987 Local Utilitarian Stonewares: A Diminishing Artifact Category. In Historic Buildings, Material Culture, and People of the Prairie Margin: Architecture, Artifacts, and Synthesis of Historic Archaeology, edited by David H. Jurney and Randall W. Moir, pp. 121142. Richland Creek Technical Series, Vol. V. Archaeology Research Program, Institute for the Study of Earth and Man, Southern Methodist University, Dallas.

Leibowitz, Joan

1985 Yellow Ware: The Transitional Ceramic. Schiffer Publishing, Ltd., Atglen, Pennsylvania.

Litwack, Leon F., Winthrop D. Jordan, Richard Hofstadter, William Miller, and Daniel Aaron

1987 The United States: Becoming A World Power, Vol. II. Prentice Hall, Inc. Englewood Cliffs, New Jersey.

Lynch, John D.

1885 The Bench and Bar of Texas. NixonJones Publishing Company, St. Louis, Missouri.

Mace, O. Henry 1991 Collector's Guide to Victoriana. Wallace-
Homestead Book Co., Radnor, Pennsylvania.

Majewski, Teresita

1996 Historical Ceramics. In Three Farewells to Manzanar: The Archeology of Manzanar National Historic Site, California, Part 3: Appendices and References, edited by Jeffrey F. Burton, pp. 793-862. Publications in Anthropology 67. Western Archeological and Conservation Center, National Park Service, U.S. Department of the Interior, Tucson.

Majewski, Teresita, and Michael J. O'Brien 1987 The Use and Misuse of NineteenthCentury English and American Ceramics in Archaeological Analysis. In Advances in Archaeological Method and Theory, Volume II, edited by Michael B. Schiffer, pp. 97-209. Academic Press, San Diego.

McQueen, The Reverend Burnell J. E.

1999 Interview with The Reverend Burnell J. E. McQueen, April 13, 1999, Austin, Texas, by Terri Myers.

Morrison and Formey

1909 Austin City Directory. Morrison and Formey, Galveston, Texas.

Mullins, Paul R.

1999 Race and the Genteel Consumer: Class and African-American Consumption, 1850-1930. Historical Archaeology $33(1): 22-38$.

Munsey, Cecil

1970 The Illustrated Guide to Collecting Bottles. Hawthorn Books, Inc., New York.

Newning, Charles.

1901 Austin Texas Illustrated: Famous Capital City of the Lone Star State. Southwest Publishing Company, Houston, Texas.

Newton, Mabel Walker

1999 Interviews with Mabel Walker Newton, January 29 and November 22, 1999 , Austin, Texas, by Terri Myers.

Noël Hume, Ivor

1991 A Guide to Artifacts of Colonial America. Vintage Books, New York. 
Pool, Juliann C.

1987 Appendix V: Fanthorp Inn: A Study of Nineteenth and Twentieth Century Buttons. In Archeological Excavations at Fanthorp Inn State Historic Site (41GM79), Grimes County, Texas, 1982, by J. David Ing and John Hart, pp. 277293. Texas Parks and Wildlife Department, Historic Sites and Restoration Branch, Austin.

Praetzellis, Mary, Betty Rivers, and Jeanette K. Schulz

1983 Ceramic Marks from Old Sacramento. California Archeological Reports No. 22. Cultural Resource Management Unit, Resource Protection Division, Department of Parks and Recreation, Sacramento.

Randall, Mark E.

1979 Marbles as Historical Artifacts. Marble Collectors Society of America. Trumbull, Connecticut.

Robinson, Lillian

1987 Interview with Lillian Robinson, October 12, 1987, Austin, Texas, by John W. Clark Jr.

Rock, James T.

1984 Cans in the Countryside. Historical Archaeology 18(2):97-111.

1987 A Brief Commentary on Cans. Cultural Resource Management, Klamath National Forest, Region 5, Department of Agriculture, U.S. Forest Service.

Russell and Erwin Manufacturing Company 1865 Illustrated Catalogue of American Hardware of the Russell and Erwin Manufacturing Company. Unabridged Reprint in 1980. The Association for Preservation Technology, Baltimore, Maryland.

St. Stephens Missionary Baptist Church

1998 St. Stephens Missionary Baptist Church Dedication Ceremony (commemorative booklet), Austin, Texas.

Schulz, Peter D., Betty J. Rivers, Mark M. Hales, Charles A. Litzinger, and Elizabeth A. McKee

1980 The Bottles of Old Sacramento: A Study of Nineteenth-Century Glass and Ceramic Retail Containers, Part I. California Archeological Reports No.
20. Department of Parks and Recreation, Sacramento.

Shelby, Alma Mae

1987 Interview with Alma Mae Shelby, October 15, 1987, Austin, Texas, by John W. Clark Jr.

Spivey, Towana (editor)

1979 A Historical Guide to Wagon Hardware \& Blacksmith Supplies. Contributions of the Museum of the Great Plains No. 9. Lawton, Oklahoma.

Stewart-Abernathy, Leslie C.

1986 The Moser Farmstead-Independent but not Isolated: The Archeology of a Late Nineteenth Century Ozark Farmstead. Arkansas Archeological Survey Research Series No. 26. W. Frederick Limp, Series Editor. Fayetteville, Arkansas.

Sussman, Lynne

1997 Mocha, Banded, Cat's Eye, and Other Factory-Made Slipware. Monograph series No. 1. Studies in Northeast Historical Achaeology, Council for Northeast Historical Archaeology.

Switzer, Ronald R.

1974 The Bertrand Bottles: A Study of 19th Century Glass and Ceramic Containers. National Park Service, U.S. Department of the Interior, Washington, D.C.

Teague, George A.

1980 Reward Mine and Associated Sites, Historical Archeology on the Papago Reservation. Publications in Anthropology II. Western Archeological and Conservation Center, National Park Service, Tucson, Arizona.

Texas. Ad valorem tax records

1848-1865

1874-1877

$1881-1885$

$1885-1900$

1915

1940

Texas Historical Commission

1988 St. Stephens Missionary Baptist Church historical marker files.

Texas. General Land Office 1841 Bastrop County. First Class, File 77. 
Abstract 659. Patented to James Rogers, February 26, 1841.

1888 Bastrop County. First Class, File 523. Abstract 2162. Patented to Wilson Biggs, September 11, 1888.

Thompson, Eleanor

1999 Interviews with Eleanor Thompson, January and May 1999, Austin, Texas, by Terri Myers.

Thoms, Alston V. (editor)

1993 The White Creek Archaeological Project: Cultural Resources Assessments for the Proposed Texas A\&M University Wastewater Treatment Plant, Brazos County, Texas. Reports of Investigations 13. Archaeological Research Laboratory, Texas A\&M University, College Station.

Thuro, Catherine M. V.

1976 Oil Lamps: The Kerosene Era in North America. Wallace-Homestead Book Company, Radnor, Pennsylvania.

Travis County

Assessor's Abstracts of Land

Deed Records

Plat Maps

Probate Records

U.S. Bureau of the Census

1860 Travis County, Texas. Agricultural schedule.

1870 b Travis County, Texas. Population schedule.

1870 a Travis County, Texas. Agricultural schedule.

1880a Travis County, Texas. Population schedule.

1880b Travis County, Texas. Agricultural schedule.

1910 Travis County, Texas.

1920 Travis County, Texas.

Vinson, Carlos

1968 Collecting Shotshells. Gun Digest 22:91-97.

Vogelzang, Vernagene, and Evelyn Welch

1981 Graniteware: Collector's Guide with Prices. Wallace-Homestead Book Company, Lombard, Illinois.

Weeks, Emma Hancock

1937 Interview with Emma Hancock Weeks, October 1937, by Alfred E. Menn. In Slave Narratives, Travis County. Transcribed from original transcripts in the Austin-Travis County Collection, Austin Public Library.

Willett, C., and Phillis Cunnington

1992 The History of Underclothes. Originally published in 1951 by Michael T. Joseph Ltd., London. Dover Publications, Inc., New York.

Wilson, Rex L.

1981 Bottles on the Western Frontier. University of Arizona Press, Tucson.

Woodhead, E. I., C. Sullivan, and G. Gusset 1984 Lighting Devices in the National Reference Collection, Parks Canada. National Historic Parks and Sites, Canadian Parks Service, Ottawa. 



\title{
APPENDIX: INVENTORY OF HISTORIC ARTIFACTS
} BY PROVENIENCE

\author{
Marie E. Blake
}




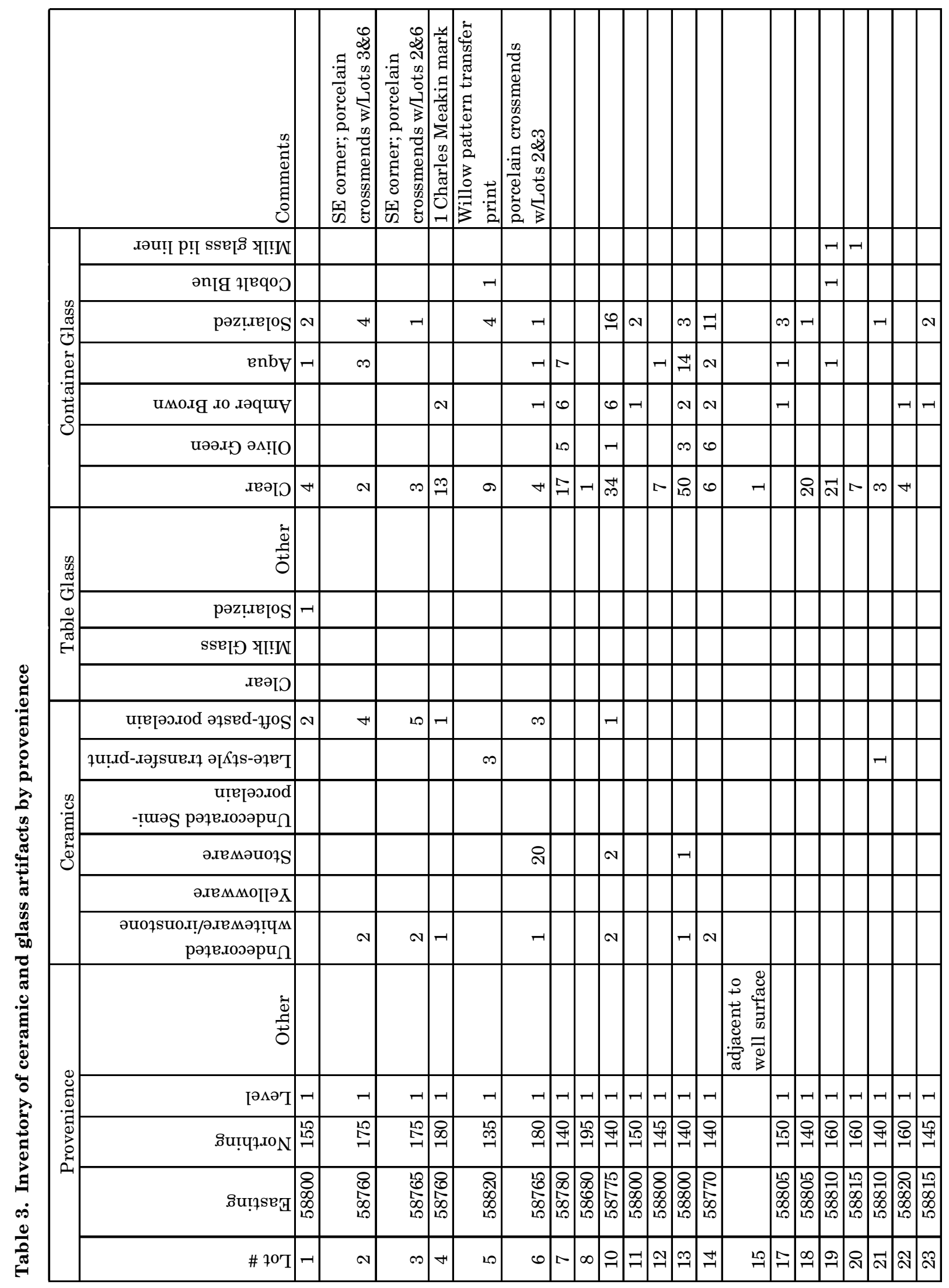


The Rubin Hancock Farmstead, 1880-1916

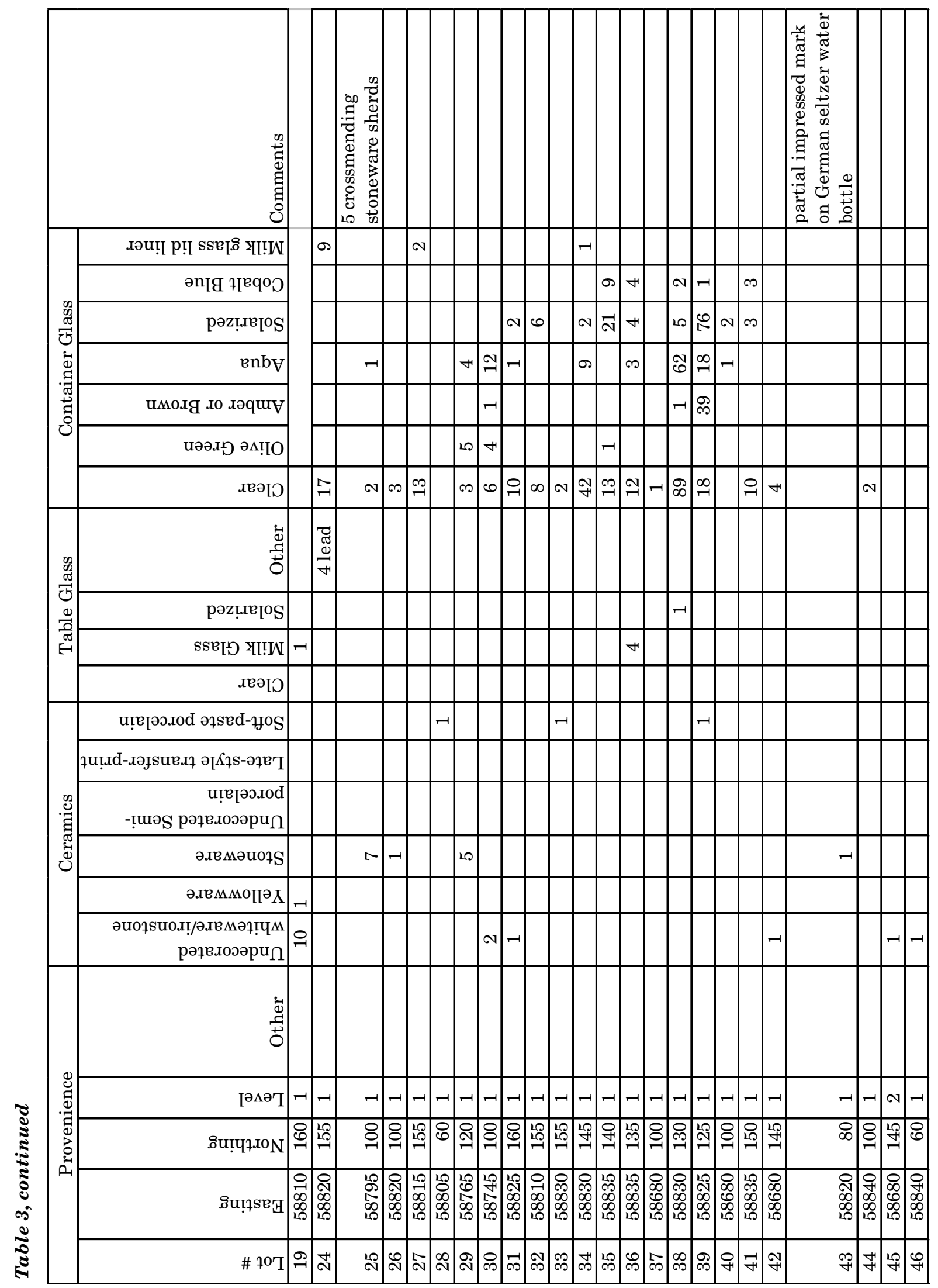


Appendix

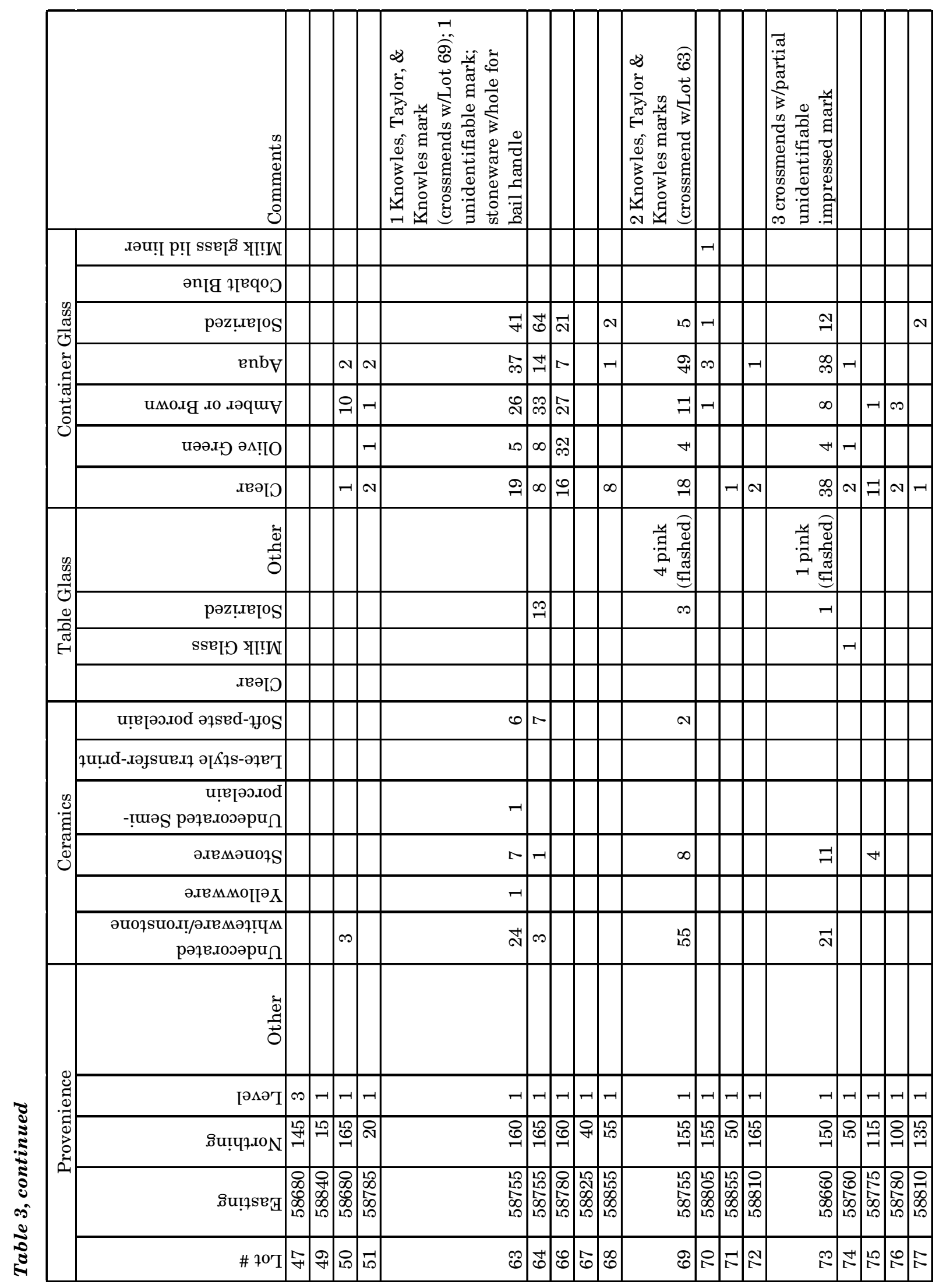


The Rubin Hancock Farmstead, 1880-1916

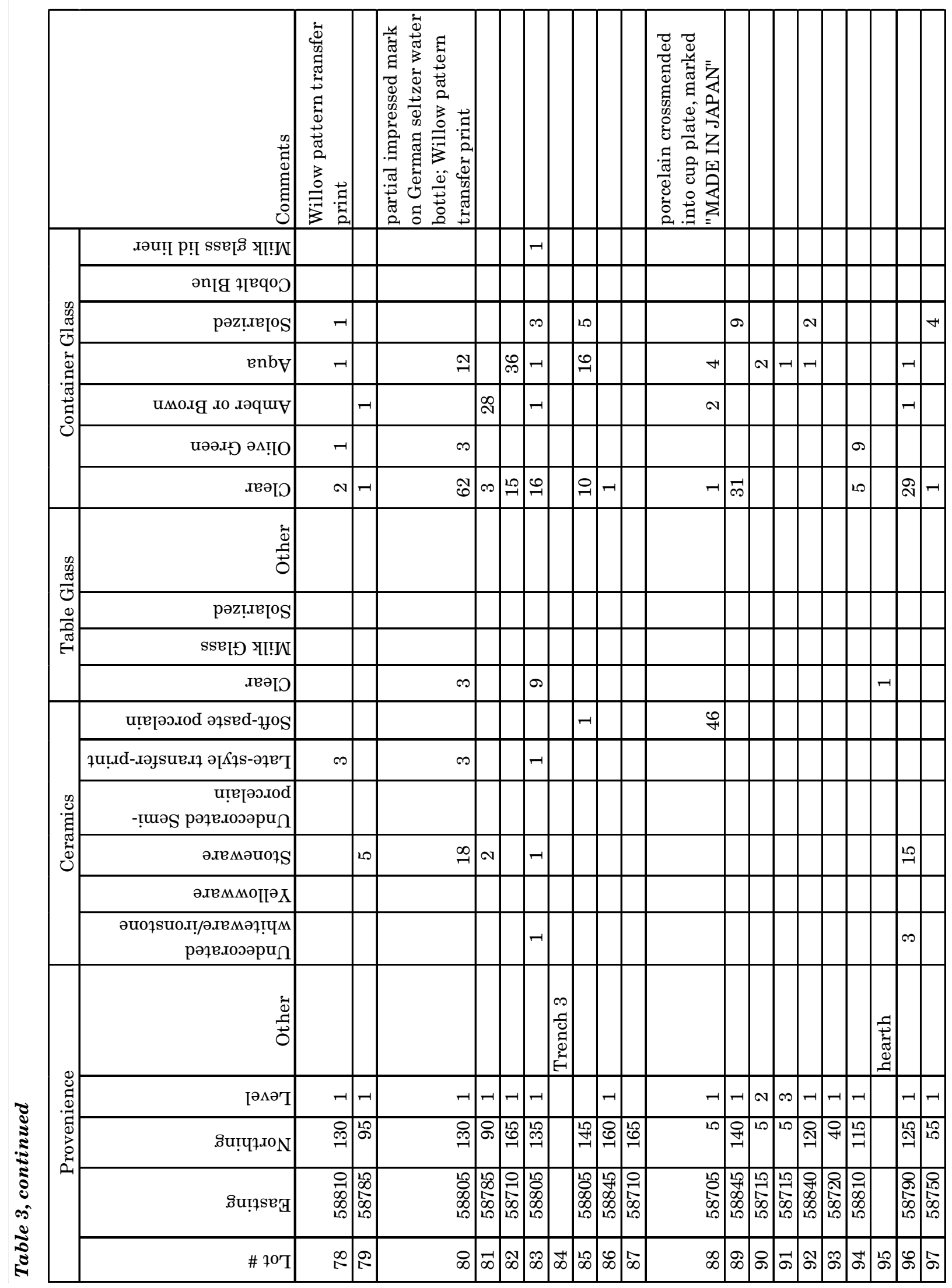




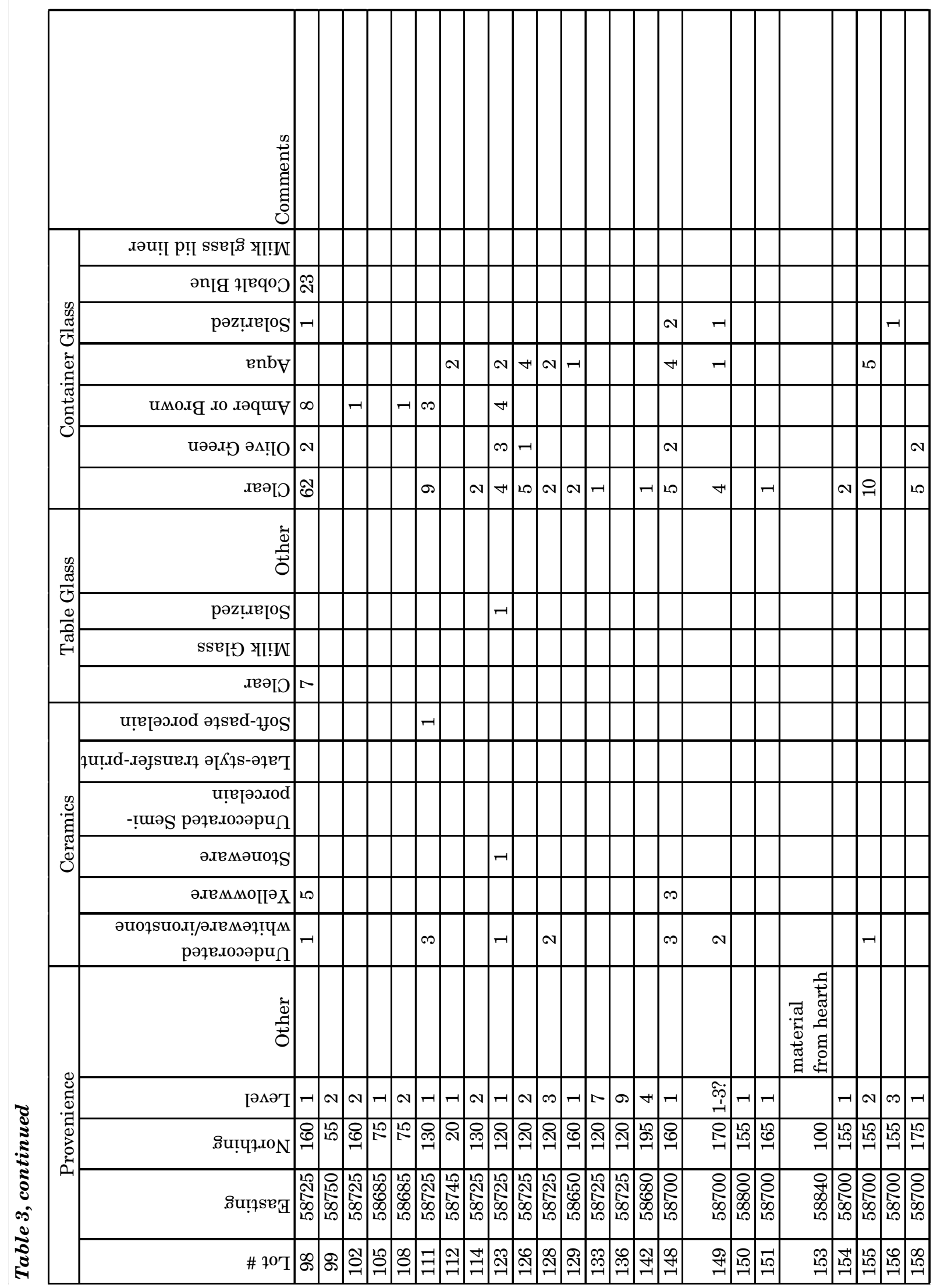


The Rubin Hancock Farmstead, 1880-1916

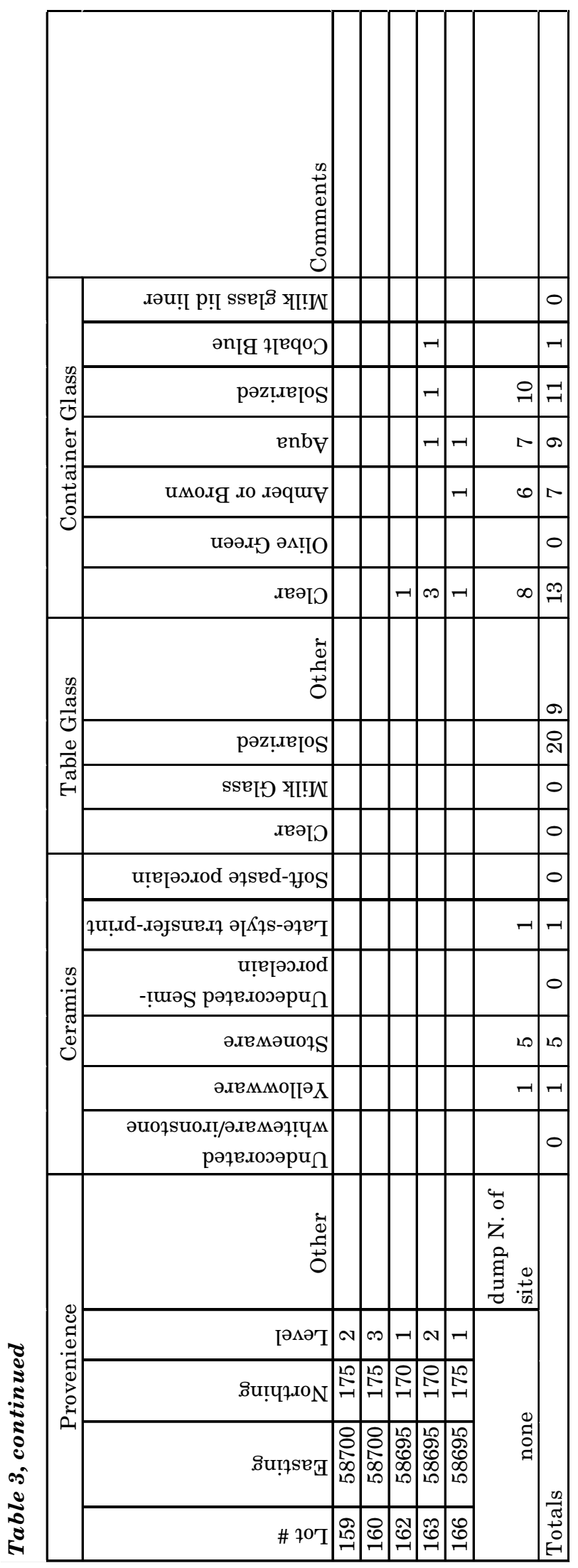




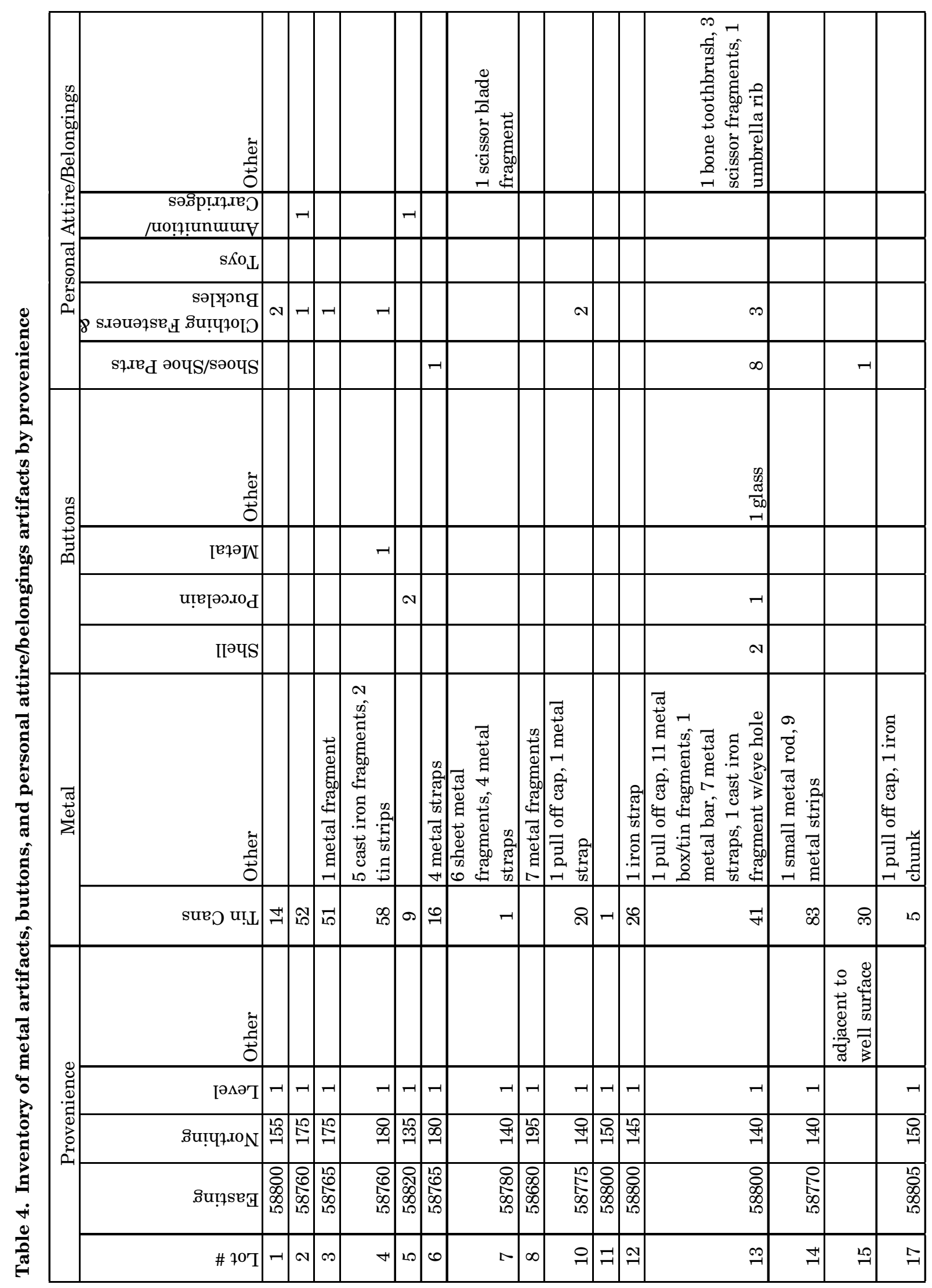


The Rubin Hancock Farmstead, 1880-1916

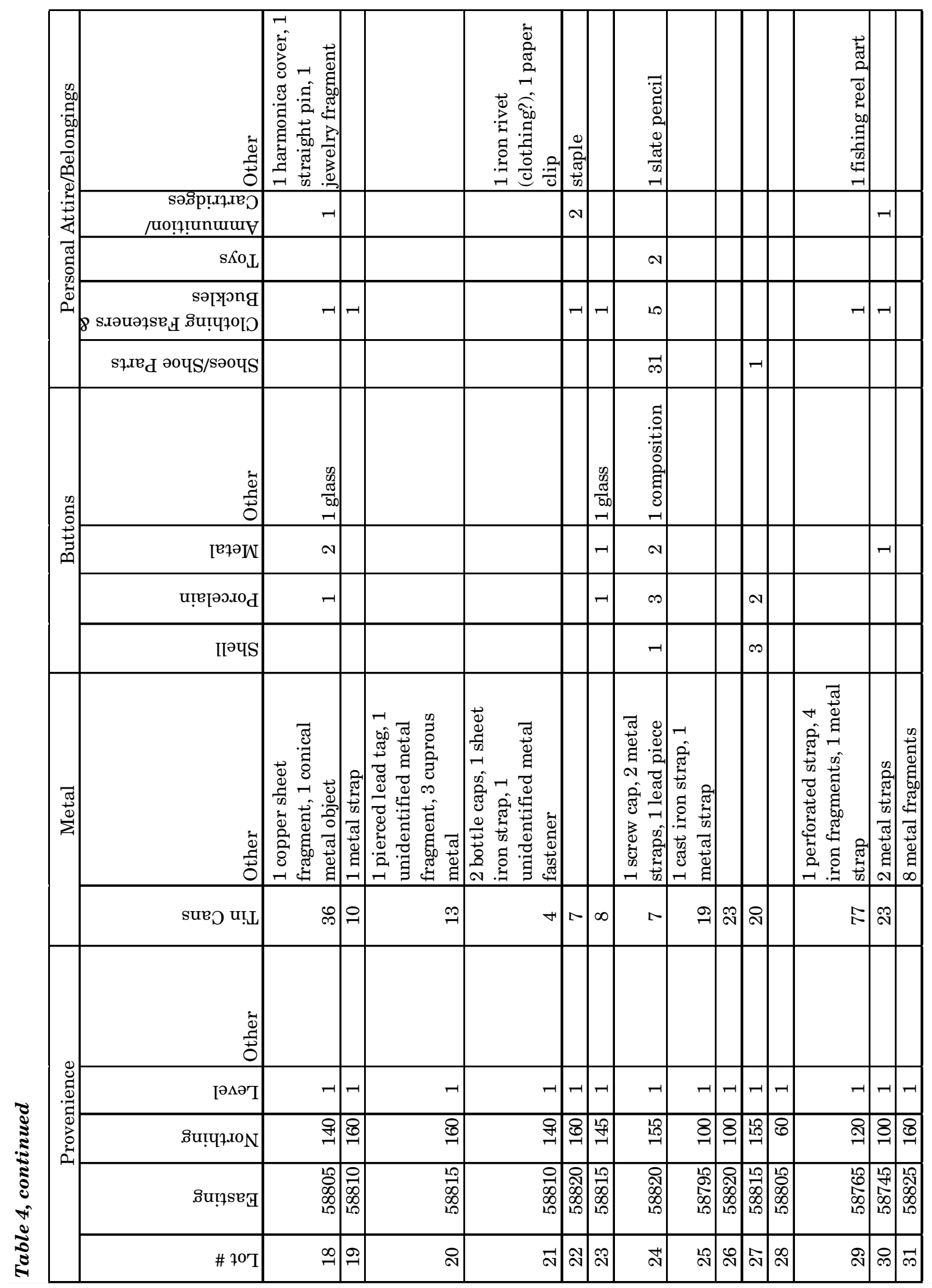


Appendix

\begin{tabular}{|c|c|c|c|c|c|c|c|c|c|c|c|}
\hline 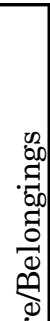 & 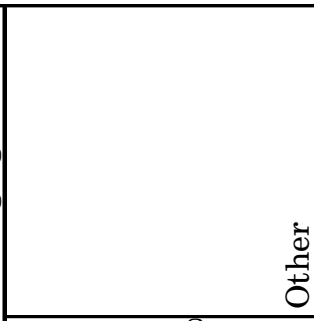 & & 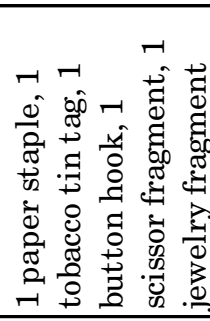 & 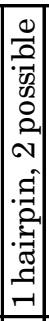 & 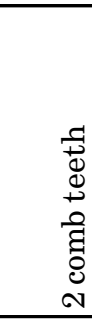 & 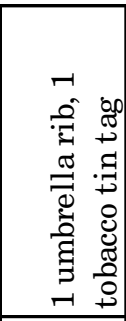 & & 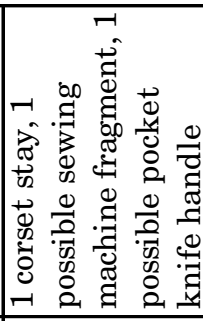 & & & 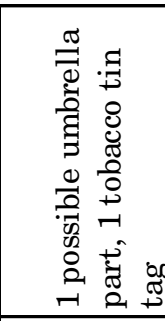 \\
\hline 焉 & 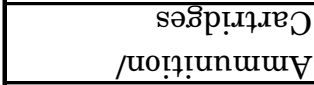 & & & -1 & & -1 & & -1 & & & \\
\hline శ్రే & $\mathrm{SKO}_{\amalg}$ & & & & -1 & & & - & & & \\
\hline 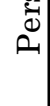 & 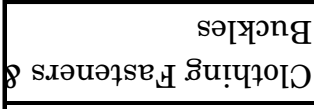 & & $\infty$ & -1 & -1 & -1 & & $\infty$ & -1 & & N \\
\hline & słле $_{\mathrm{d}}$ әочS/sәочS & & & & & $N$ & & & & & N \\
\hline $\begin{array}{l}\text { tొ } \\
\text { : }\end{array}$ & $\frac{\dot{\Phi}}{\stackrel{d}{0}}$ & & & 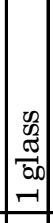 & & & & & & & $\begin{array}{l}02 \\
\frac{7}{6} \\
\frac{\pi}{60} \\
-1\end{array}$ \\
\hline$\vec{n}$ & [вұәәN & & -1 & $\sim$ & -1 & -1 & & & -1 & & -1 \\
\hline & u!̣е|әәлос & -1 & N & -1 & & & & & & & \\
\hline & IIәЧS & & N & $\infty$ & & & & & & & \\
\hline 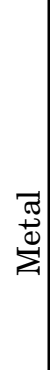 & $\frac{\dot{d}}{\tilde{0}}$ & & 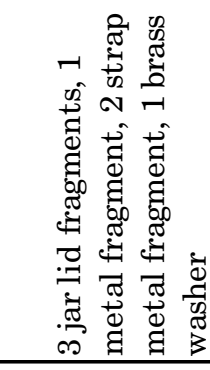 & & 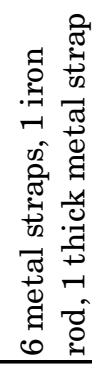 & 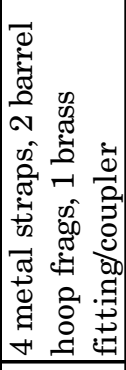 & 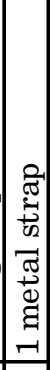 & 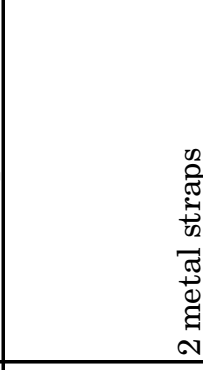 & 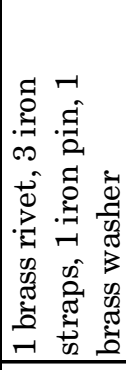 & 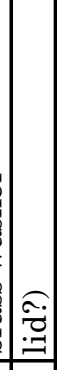 & 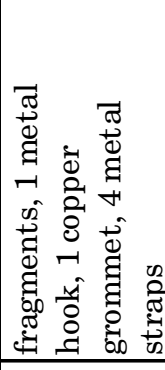 \\
\hline & sueD U!L & 荣 & $\exists$ & $\infty$ & $\stackrel{\sim}{\sim}$ & - & & $\stackrel{10}{n}$ & ค & $\infty$ & - \\
\hline & $\frac{\dot{d}}{\Delta}$ & & & & & & & & & & \\
\hline 苛 & {$\left[{ }^{\partial \Lambda \partial \top}\right.$} & -1 & -1 & -1 & -1 & -1 & -1 & -1 & -1 & -1 & - \\
\hline 范 & . & $\stackrel{10}{10}$ & 点 & 年 & g & $\begin{array}{l}10 \\
\stackrel{2}{2}\end{array}$ & $\underset{-1}{8}$ & $\stackrel{\substack{9 \\
\sim}}{\sim}$ & $\stackrel{2}{\mathrm{~N}}$ & 8 & 量 \\
\hline & . 8 u!़Se & $\begin{array}{l}0 \\
-\infty \\
\infty \\
10 \\
10\end{array}$ & $\begin{array}{l}\mathscr{0} \\
\infty \\
\infty \\
10\end{array}$ & $\left|\begin{array}{l}\infty \\
\infty \\
\infty \\
\infty \\
10\end{array}\right|$ & $\begin{array}{l}120 \\
\infty \\
\infty \\
10\end{array}$ & $\begin{array}{l}10 \\
0 \\
\infty \\
0 \\
10\end{array}$ & $\left|\begin{array}{l}8 \\
0 \\
0 \\
10\end{array}\right|$ & $\begin{array}{l}0 \\
\infty \\
\infty \\
\infty \\
10\end{array}$ & $\begin{array}{l}10 \\
\infty \\
\infty \\
\infty \\
10\end{array}$ & $\begin{array}{l}8 \\
0 \\
0 \\
0 \\
1 \\
1\end{array}$ & $\begin{array}{l}10 \\
\infty \\
\infty \\
10 \\
10\end{array}$ \\
\hline & \# 70 $\mathrm{T}$ & ๙ิ & ๓ొ & m & $\stackrel{20}{\infty}$ & $\stackrel{\infty}{\infty}$ & 全 & $\stackrel{\infty}{\infty}$ & கి & 아 & F \\
\hline
\end{tabular}


The Rubin Hancock Farmstead, 1880-1916

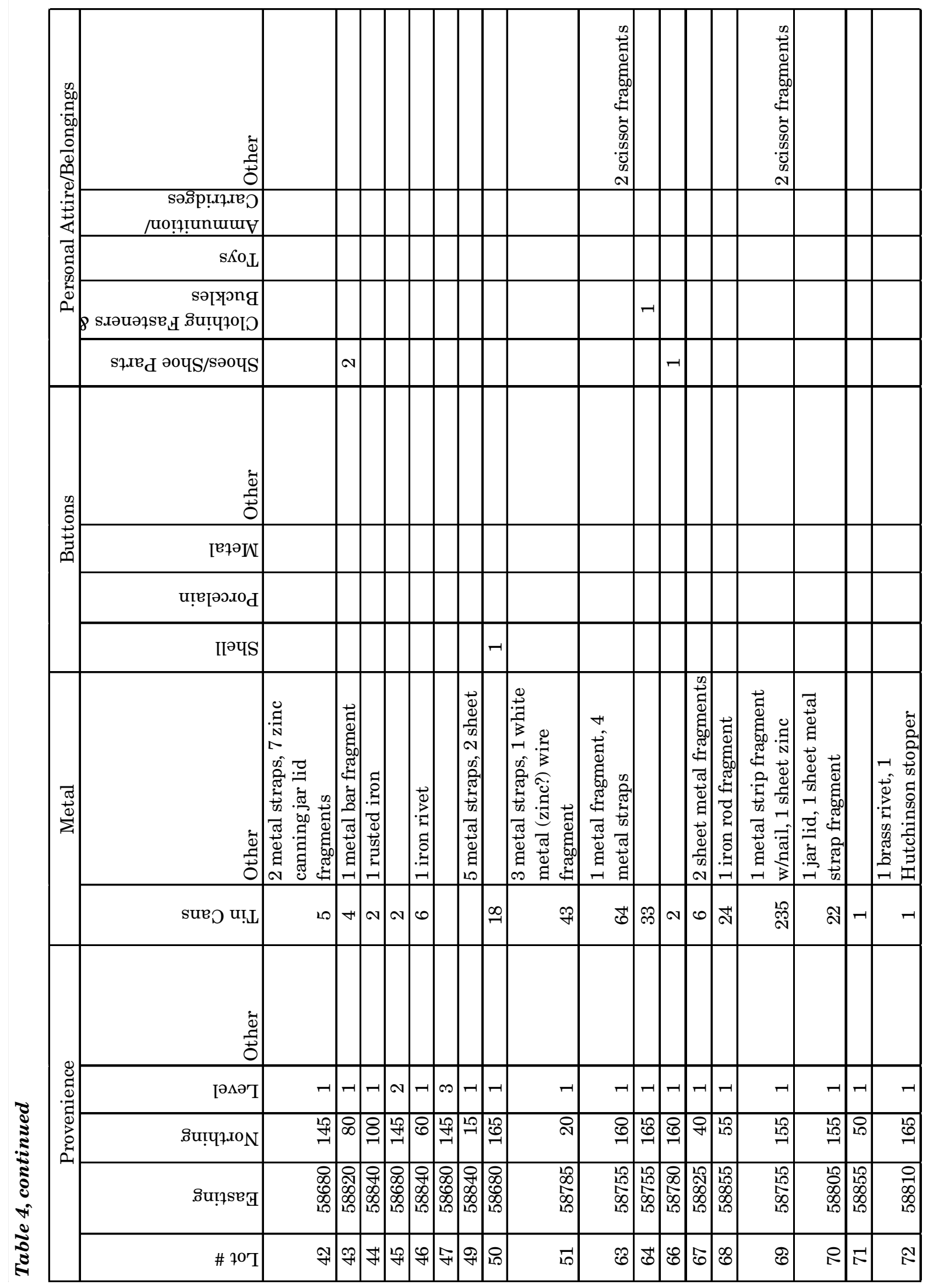


Appendix

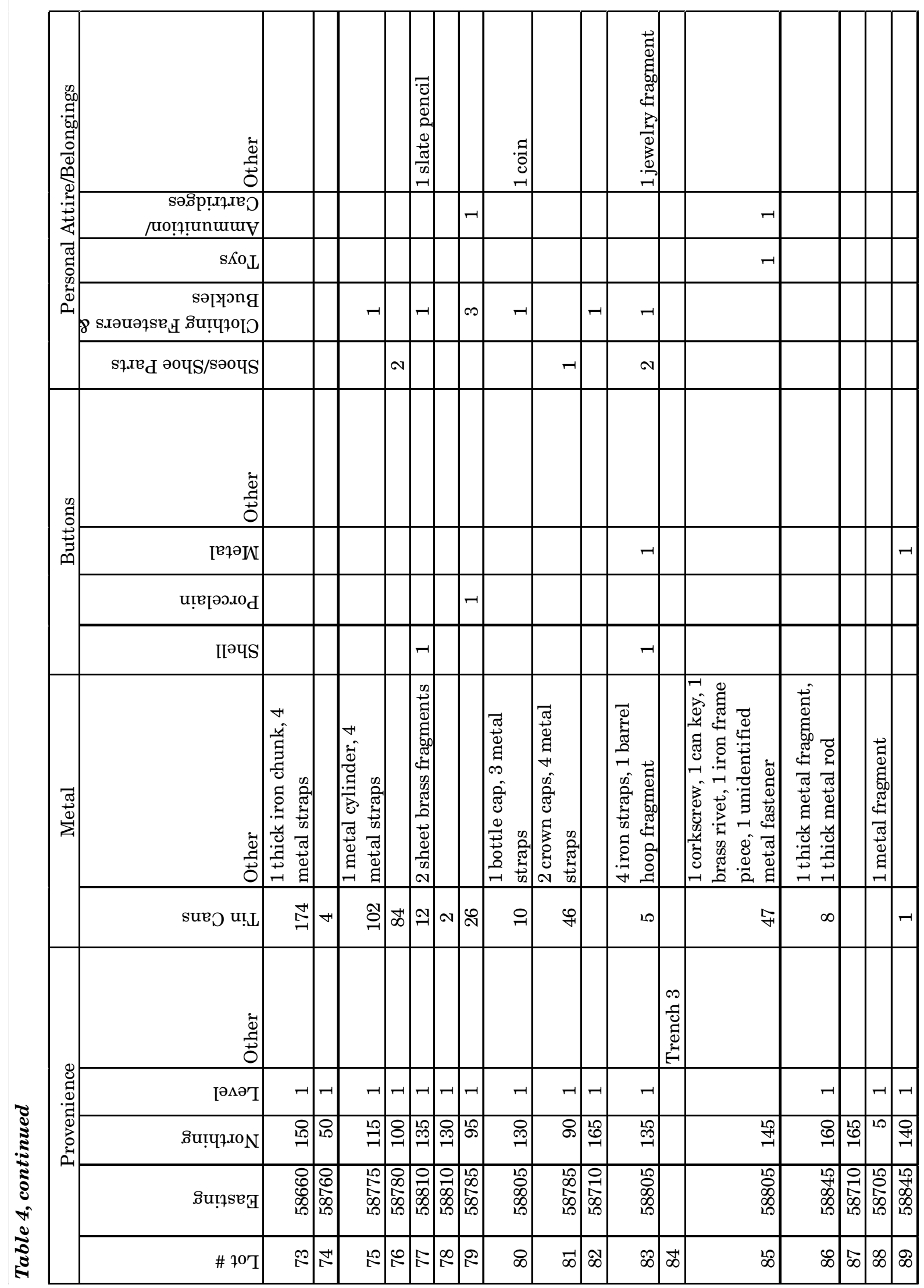


The Rubin Hancock Farmstead, 1880-1916

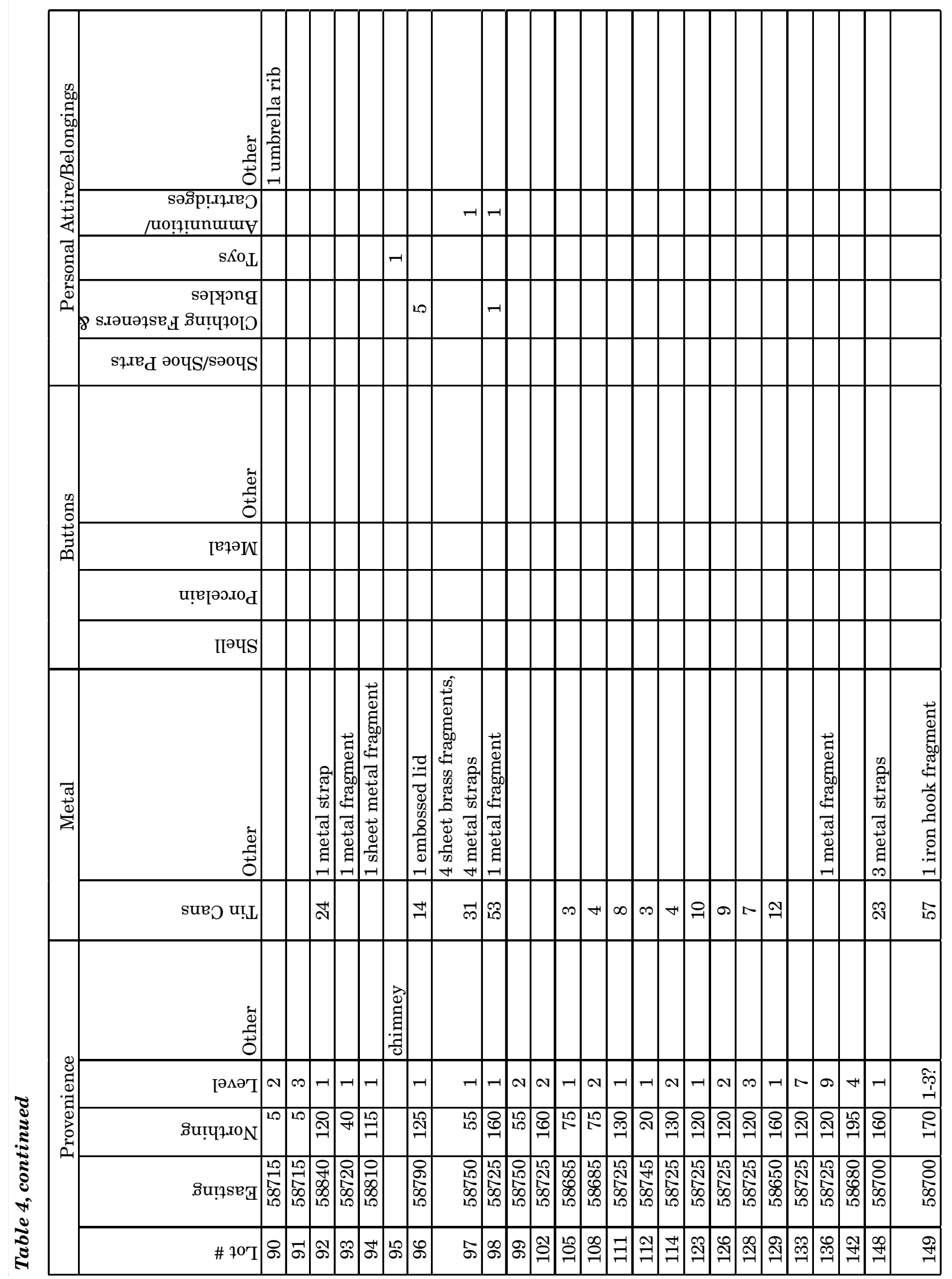


Appendix

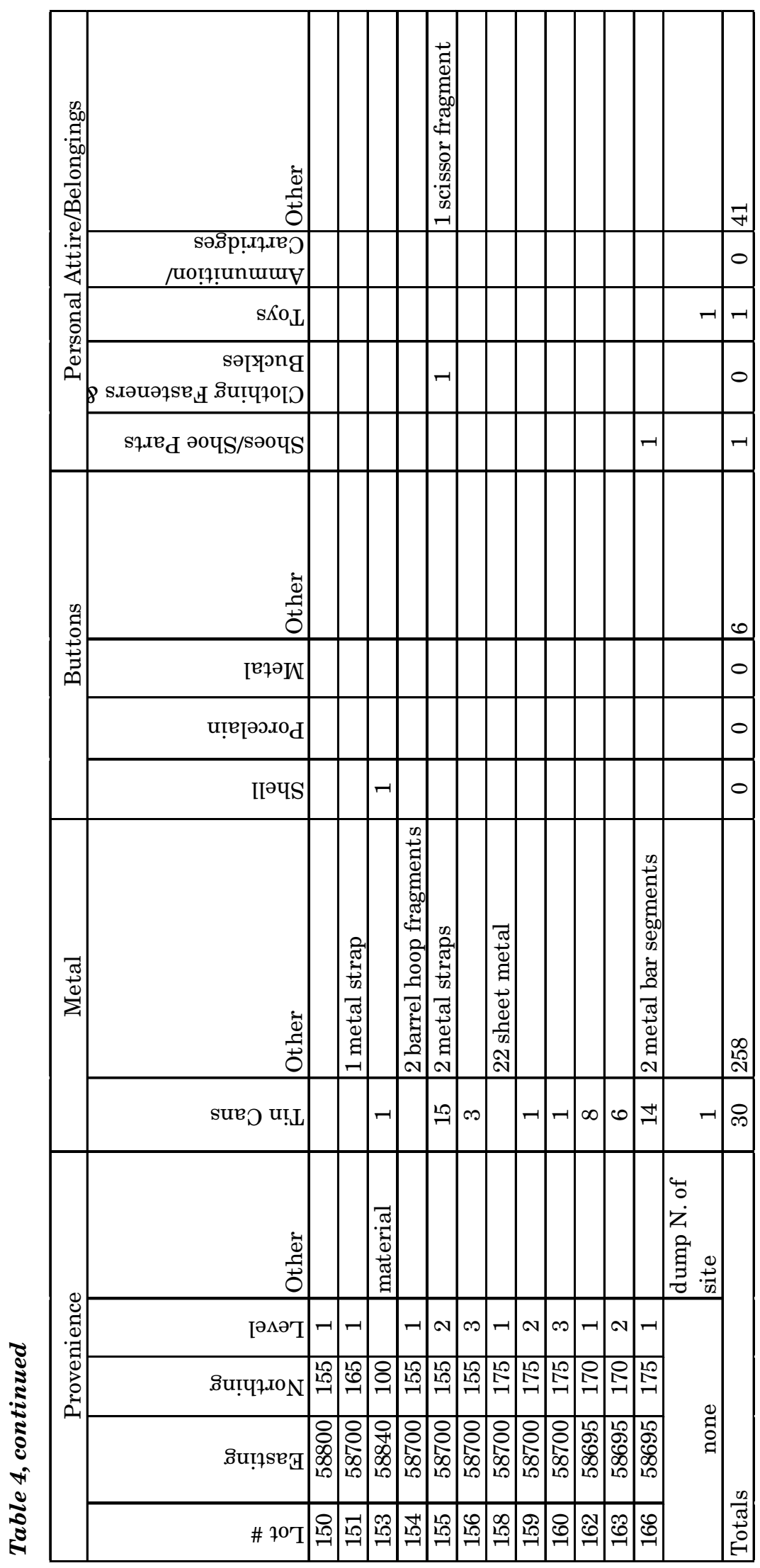




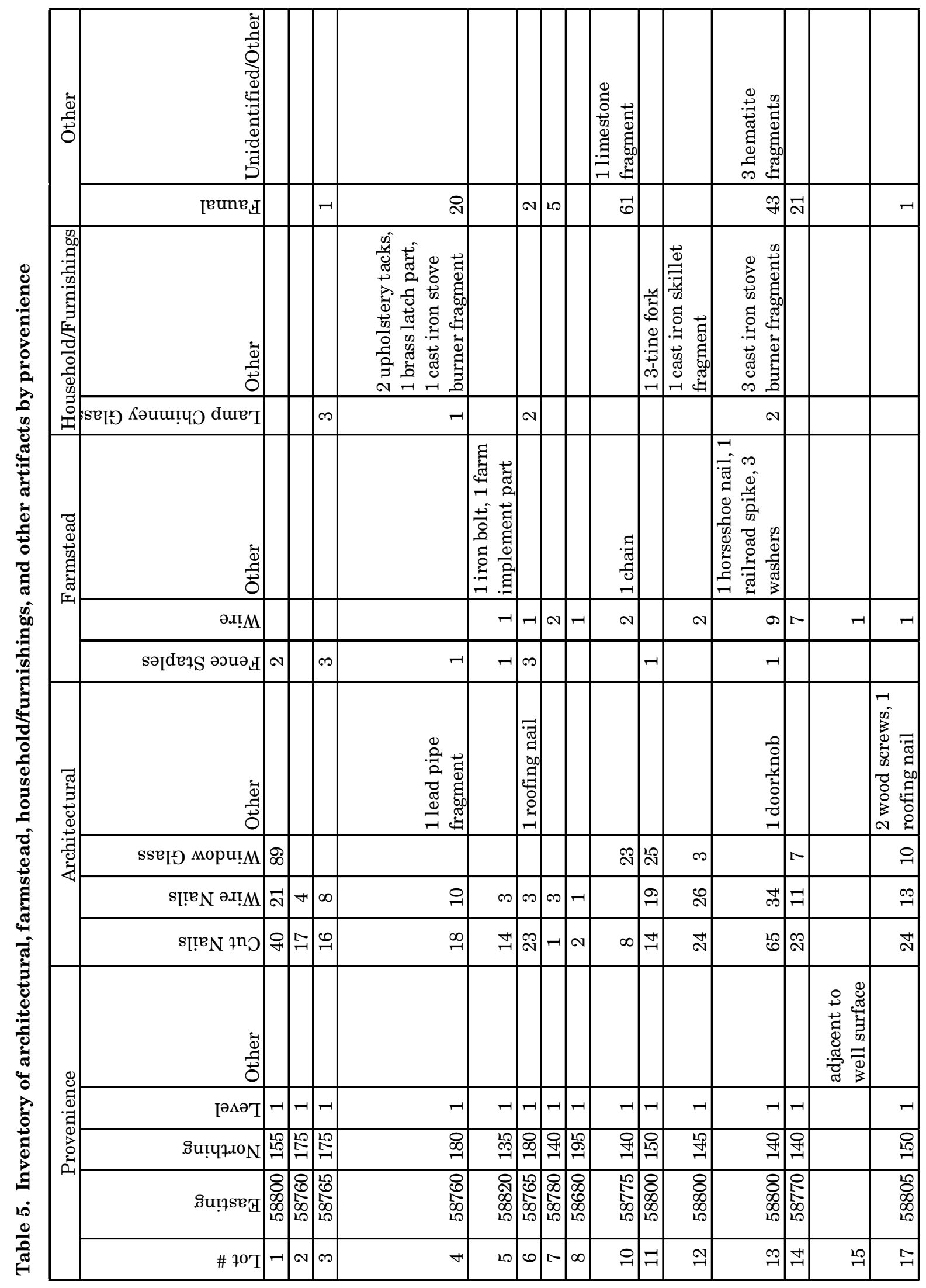


Appendix

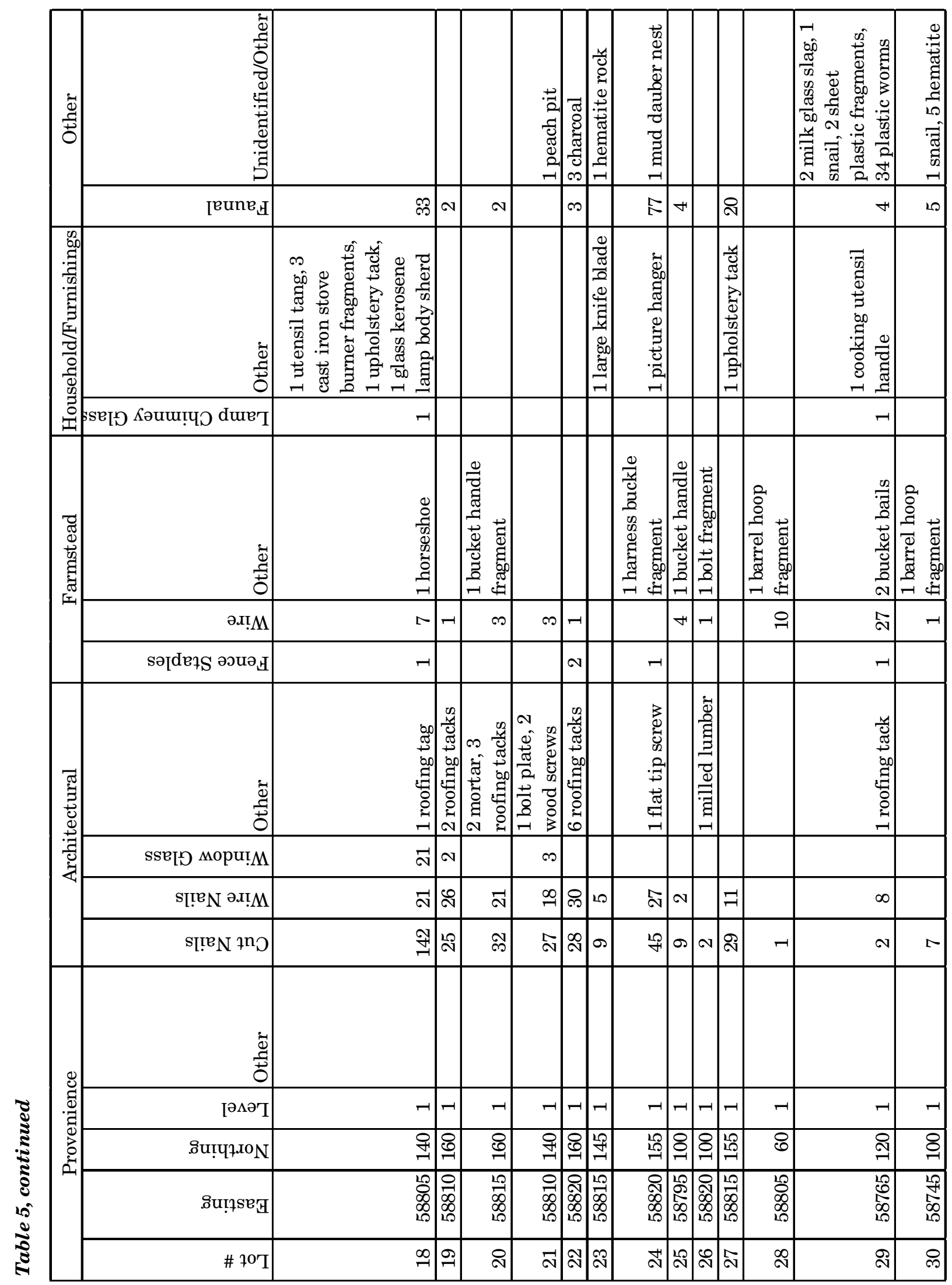


The Rubin Hancock Farmstead, 1880-1916

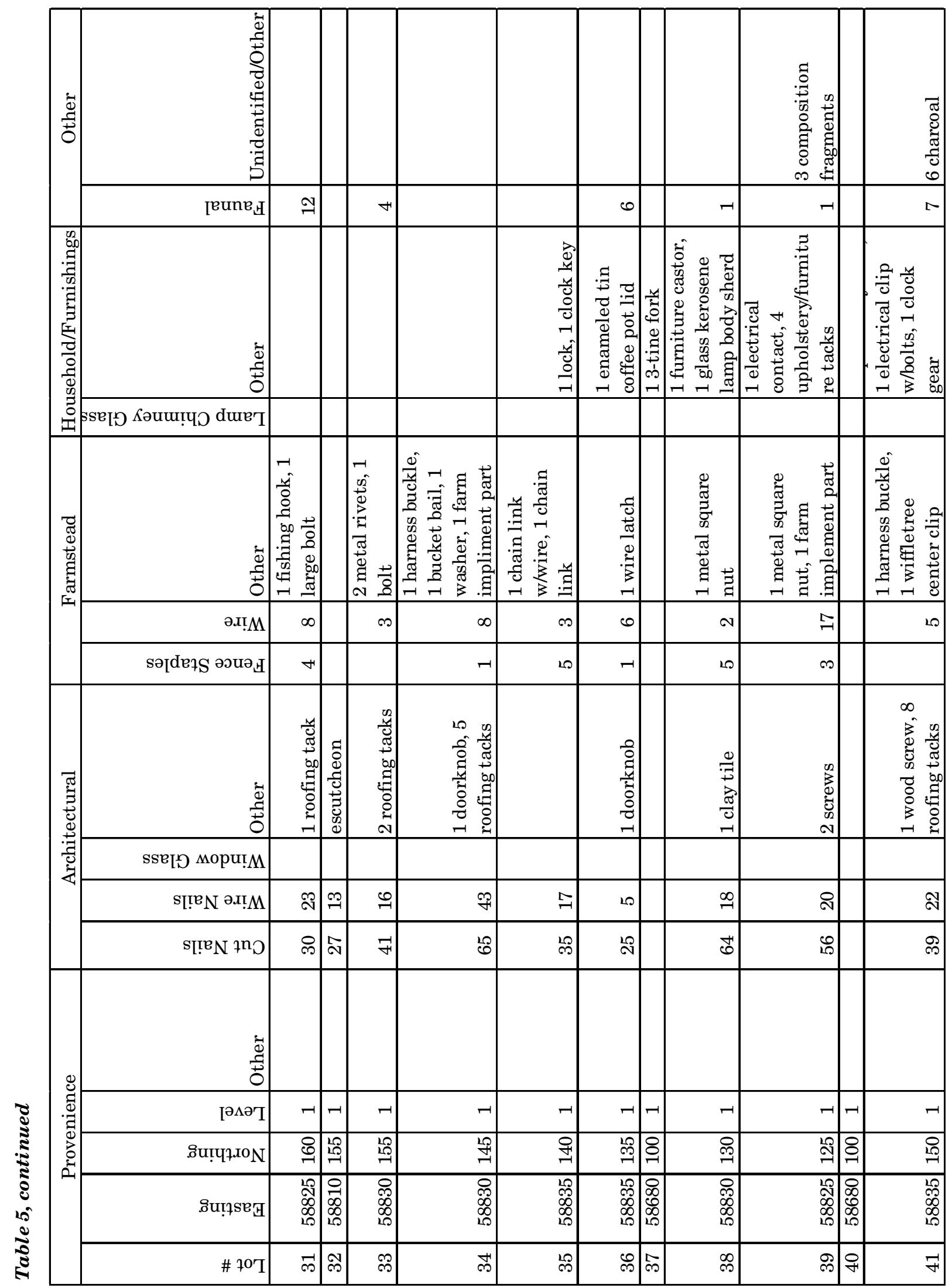


Appendix

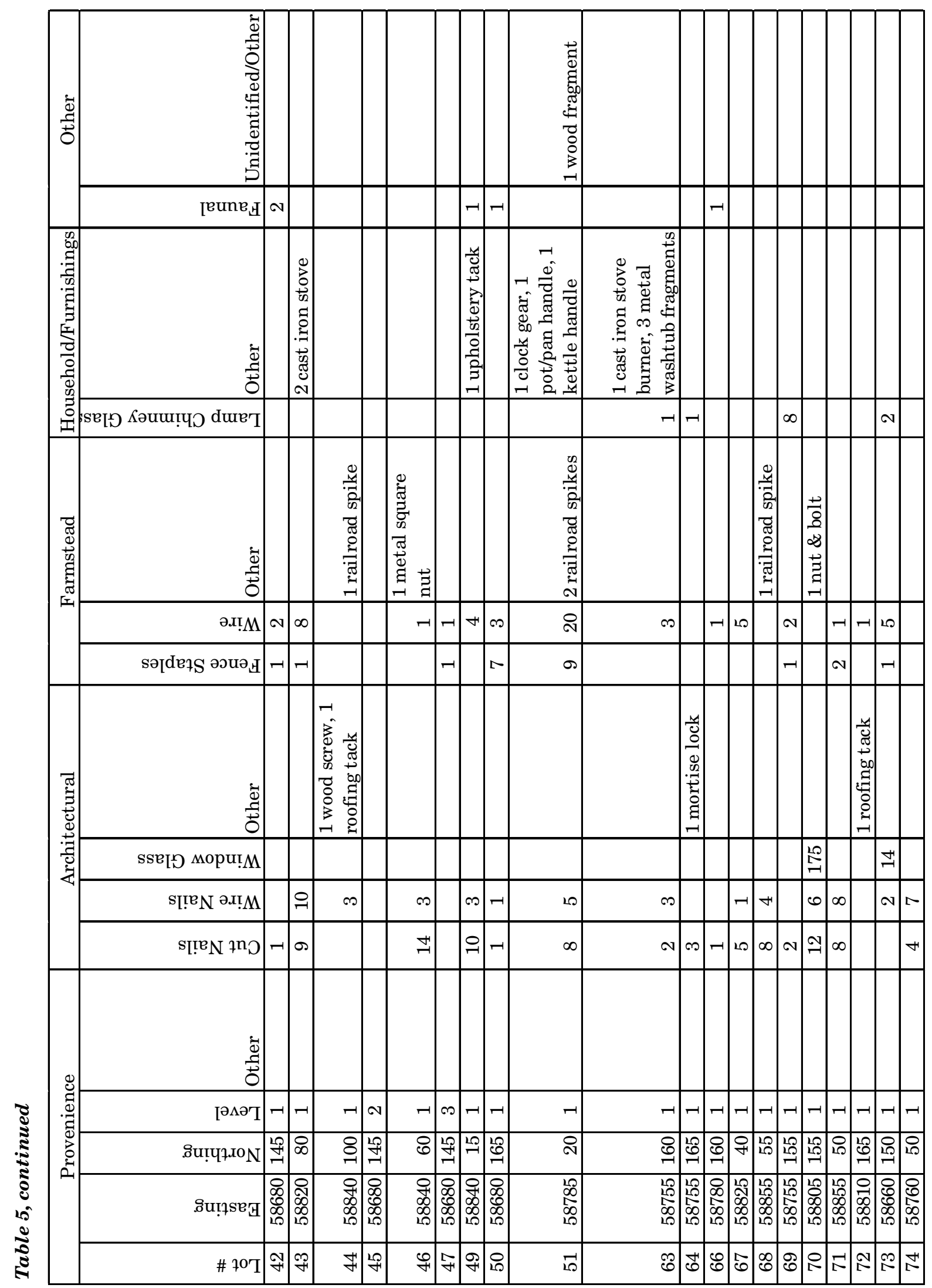


The Rubin Hancock Farmstead, 1880-1916

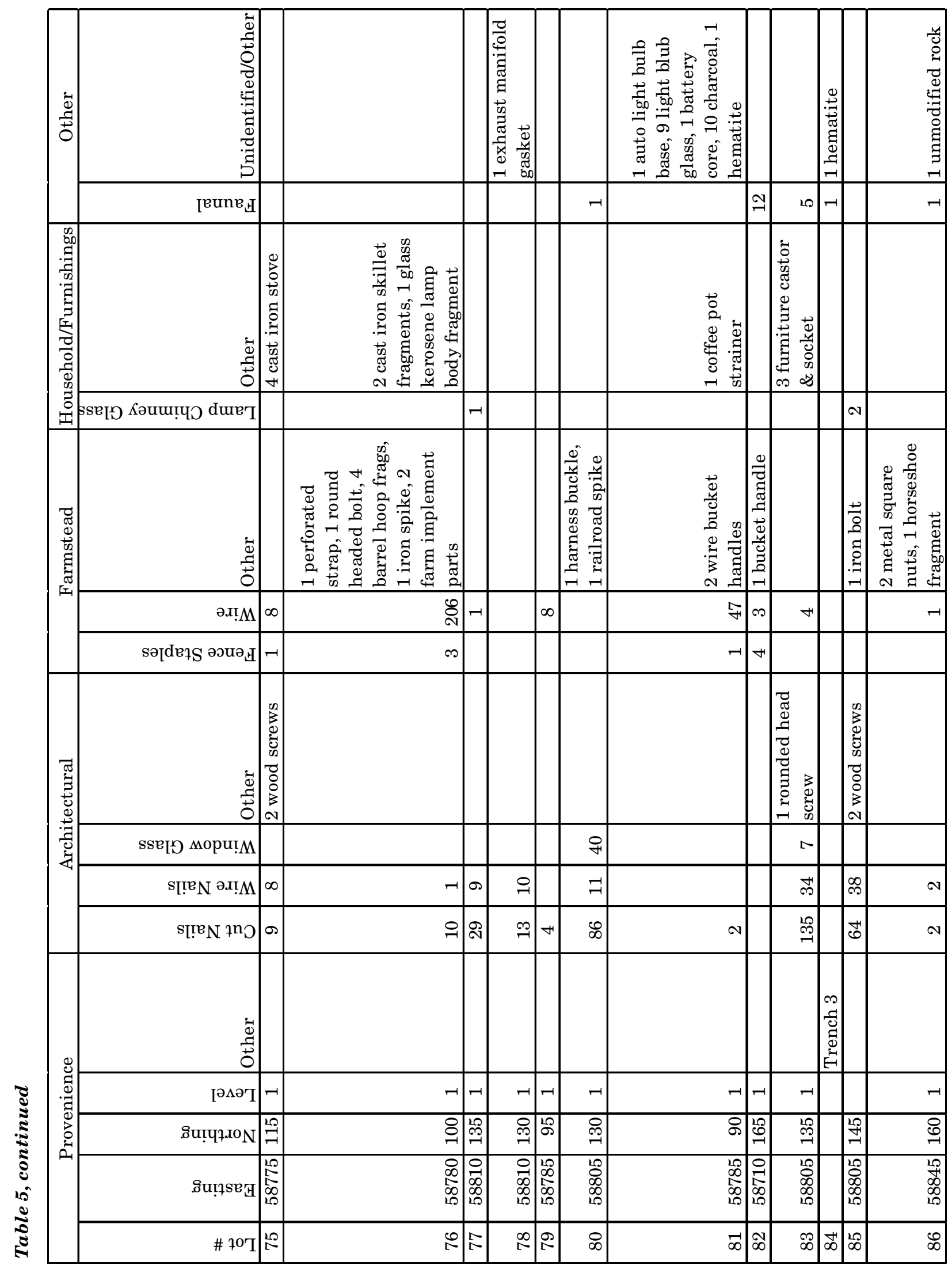


Appendix

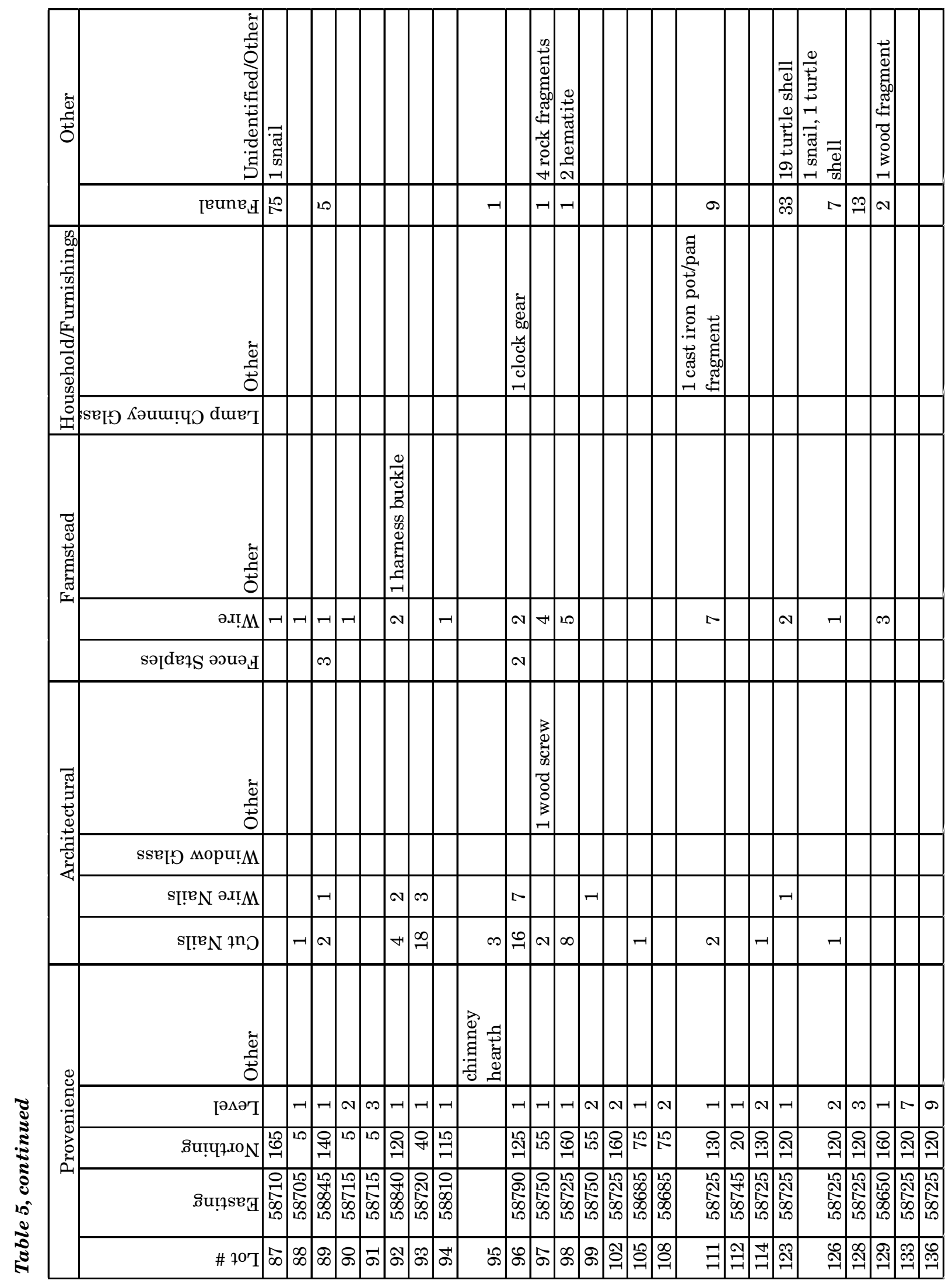




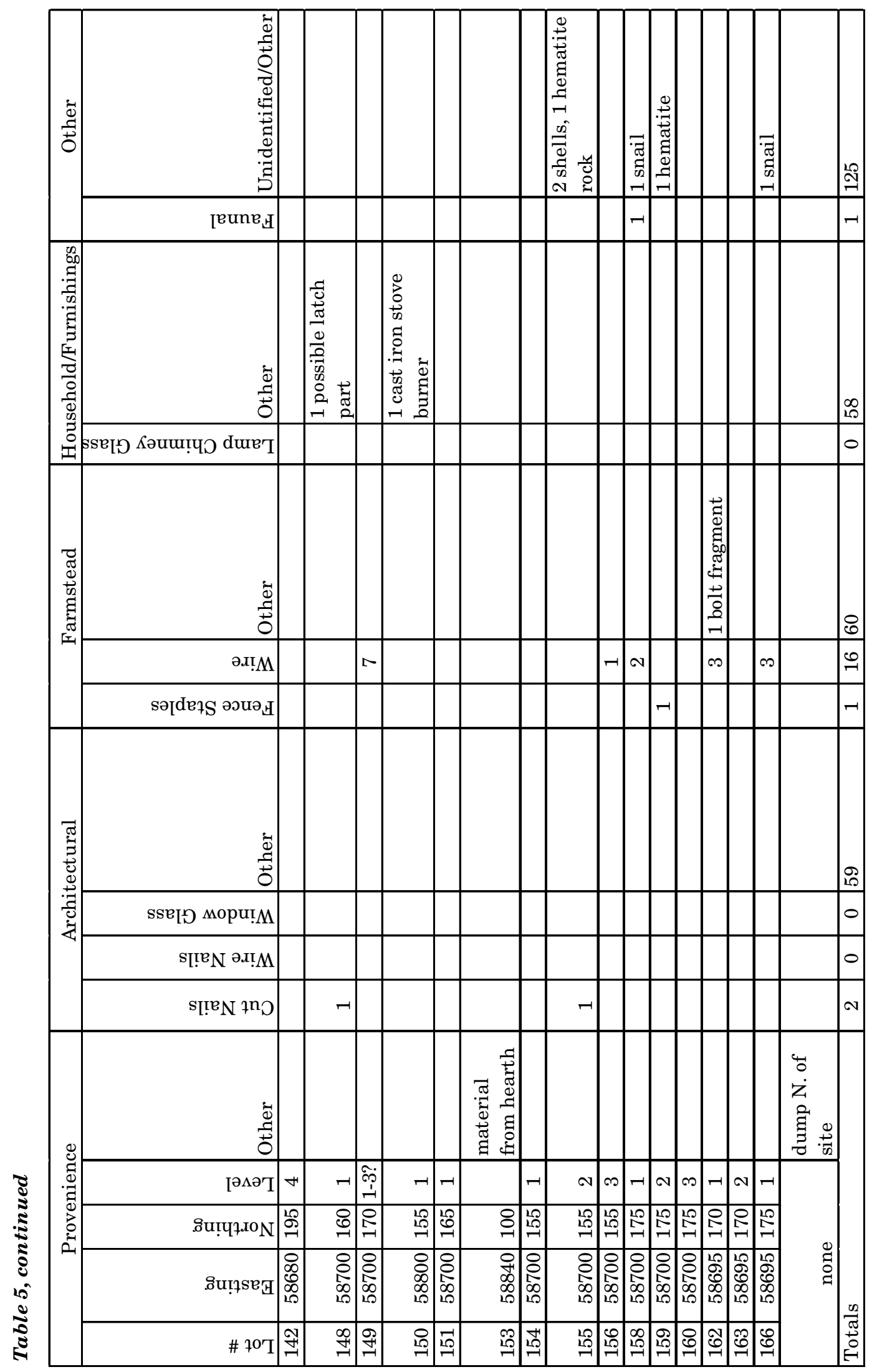

